https://theses.gla.ac.uk/

Theses Digitisation:

https://www.gla.ac.uk/myglasgow/research/enlighten/theses/digitisation/

This is a digitised version of the original print thesis.

Copyright and moral rights for this work are retained by the author

A copy can be downloaded for personal non-commercial research or study, without prior permission or charge

This work cannot be reproduced or quoted extensively from without first obtaining permission in writing from the author

The content must not be changed in any way or sold commercially in any format or medium without the formal permission of the author

When referring to this work, full bibliographic details including the author, title, awarding institution and date of the thesis must be given

Enlighten: Theses

https://theses.gla.ac.uk/

research-enlighten@glasgow.ac.uk 


\title{
Theological Hermeneutics and 1 Thessalonians
}

\author{
Angus Alexander Paddison
}

Submitted for the degrec of Doctor of Philosophy to the University of Glasgow, Faculty of Arts, Department of 'Theology and Religious Studies.

(C) January 2004 
ProQuest Number: 10390821

All rights reserved

INFORMATION TO ALL USERS

The quality of this reproduction is dependent upon the quality of the copy submitted.

In the unlikely event that the author did not send a complete manuscript and there are missing pages, these will be noted. Also, if material had to be removed, a note will indicate the deletion.

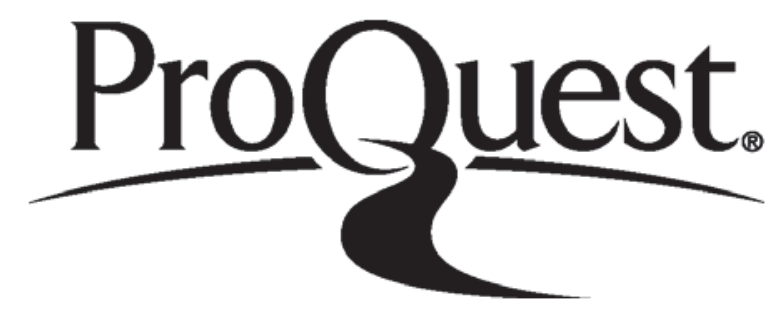

ProQuest 10390821

Published by ProQuest LLC (2017). Copyright of the Dissertation is held by the Author.

All rights reserved.

This work is protected against unauthorized copying under Title 17, United States Code Microform Edition (c) ProQuest LLC.

ProQuest LLC.

789 East Eisenhower Parkway

P.O. Box 1346

Ann Arbor, MI 48106-1346 
UNIVERSITY

LFRALI:

13166

$\operatorname{cop} \times 2$ 


\begin{abstract}
This thesis proposes a theologically engaged reading of 1 Thessalonians.

The thesis has three parts. Part 1 critiques current historical-critical readings of 1 'I'hessalonians, arguing that the interpretative perspectives offered by historicalcriticism offer little for the theologically interested exegete. Part II of the thesis explores the text's interpretation history, examining the commentaries on 1 Thessalorians of Thomas Aquinas and John Calvin. Part III proposes and develops a theologically engaged reading of Paul's letter in dialogue with an array of theological voices.
\end{abstract}

Lin the first part of the thesis historical-critical trends, dominant both within scholarship on 1 Thessalonians specifically and more general Biblical scholarship, are exposed to theological scrutiny. Chapter 1 begins by introducing some of the thesis' guiding theological and hermenetitical concepts: historicism, revelation and conversation. Informed in this way, a preliminary theological critique of historicalcrilicism is explored with reference to the work of James Dunn and Karl Donfried. Developing the argument of this chapter by drawing upon further instances of historical-criticism, it is contended that historical-critical studies operate with a limited notion of meaning and truth; that historical-criticism is disabled by a. historicist attitude that freezes the language into a restrictively reflective relationship between text and original context; and that historicist interprelalions distract its pracititioners from the actual, and most obvious, subject matter of the Biblical texts.

In the second part of the thesis the pre-modem exegesis of 1 Thessalonians, in the form of Thomas Aquinas' (1224/5-75) and John Calvin's (1509-64) respective commentaries on 1 Thessalunians, is examined and explored. Chapter 2 presents a reading of Thomas' 1 Thessalonians Lectura. Attention is paid both to the exegetical methods Thomas deploys in reading Paul's letter and the theological richness he extracts from it. Particular emphasis is placed on Thomas' engaged reading of 1 
Thessalonians 4:13-18. Chapter 3 turns to Calvin's commentary on 1 Thessalonians. As with our chapter on Thomas, a dual interest in the exegetical methods and the outcomes of this method is maintained. Although it is contended that some of Calvin's exegetical tochniques are a prelude to subsequent developments, there is much to be gained from Calvin's reading of the whole of 1 Thessalonians in an eschatological vein. Chapter 4 evaluntes these readings of Thomas and Calvin together, and notes the extent to which they have added to our expansive reading of 1 Thessalonians.

In the third part of the thesis the theologically engaged reading of 1 Thessalonians reaches its climax. The central concem of Chapter 5 is to provide a theologically attuned reading of 1 Thessalonians 4:14. The chapler commences by attempting to situate our theologically driven exegesis within an appropriate hermenentical framework, with the assistance of Karl Rahner. Subsequent attention is paid to the images of redemplion present within the text, and to that end drawing the text into conversation with an eclectic range of premodern and modern theological voices. Aspects of the text explored include Paul's claim that Jesus died 'for us' (1 Ihess 5:10), images of light and prayer, of death as sleeping, and that of the parousia itself.

In the concl usion the hermeneutical journey undertaken in the course of the thesis is evaluated, and some departing images are offered by way of reflection. 


\section{Declaration}

I affirm that this thesis is entirely my own work and that all significant quotations have been acknowledged in the footnotes. No part of this thesis has been previously submitted for any other degree. 


\section{Acknowledgements}

An immense debt of gratitude is owed to a great number of people.

Much of this research was completed whilst being in receipt of a University of Glasgow Postgraduate Scholarship. I am immensely grateful for the (then) Faculty of Divinity for this award. 1 received further financial assistance from the Chancellor's Fund (University of Glasgow); The Cross Trust (Perth); and from my parents, Ronan and Lesley Paddison. To all these individtuals and conumittees I am very grateful.

I should Iike to thank my superbly diligent and interested proofreaders, Icsley Paddison and Dimitri Vastardis. Members of the Postgraduate Biblical Studies Seminar have provided a great forum for reading the New Testament together. I have also had many stimulating conversalions with friends and inembers of staff within the Department, but outwith the Biblical Studies Seminar.

The Inter-Library Loans department of Glasgow Universily Library very helpfully supplied bibliographic resources. The National Library of Scotland, the British Library, King's College Library, Cambridge University Library, New College Library (Edinburgh) and Heythrop College Library all provided stimulating environments in which to work.

Finally, and by no means last, my supervisor, Ptofessor John M.G. Barclay, has been an endlessly generous source of scholarship, patience, guidance, and en thusiasm. For all that he has helped along its way, and for the lunches, I am extremely thankful. 


\section{Abbreviations and notes about citation}

$\mathrm{AB}$

AJT

AT'R

BJRJ.

BNTC

$B T B$

$C B Q$

$C D$

$\mathrm{CH}$

$\mathrm{CO}$

Comm. Ex.

Comm. Ezek.

Comm. Gal.

Comm. Gen.

Comm. Heb.

Comm. Isa.

Comm. Jer.

Comm. Jn.

Comm. I Peter

Comm. 2 Peter

Conm. Phil.

Comm. Pealms

Conm. Ram.

Comm. 1 Cor.

Contm. 2 Cor.

Conm. 1 Thess.

Conm. 2 Tim.

Comp. 'ineot.

CTI

CUAP

CUP

DLT

$E L R$

$E Q$

FOC

GOTR

HBT

HTR

ICC

Inst.

$J B L$

JECH

JETS

ISNT

JSNTSup

ISOT
Anchor Bible

Asia Journal of Theology

Anglican Theological Review

Bulletin of the John Rylands Library

Black's New 'lestament Commentaries

Biblical Theology Bulletion

Catholic Biblical Quarterly

Church Dogmatics

Church History

Calvini Opera

Calvin's Commentary an Fxodus

Calvin's Commentary on Ezekiel.

Calvin's Commentary on Galatians

Calvin's Commentary on Genesis

Calvin's Commentary on Hebrezes

Calvin's Commentary on Isaiah

Calvin's Conmentary on Jeremiah

Calvin's Commentary on John

Calvin's Commentary on 1 Peter

Calvin's Commentary on 2 Peter

Calvin's Commentary on Philippians

Calvin's Commentary on the Psalms

Caivin's Commentary on Romans

Calvin's Commentary on 1 Corinthians

Calvin's Commentary on 2 Corinthians

Calvin's Commentary on 1 Thessalonians

Calvin's Commentary on 2 Timothy

Compendium of Theology

Calvin Theological Journal

Catholic University of America Press

Cambridge University Press

Darton, Longman and Todd

English Literary Renaissance

Evangelical Quarterly

Fathers of the Church Series

Greek Orthodox Theological Review

Horizons in Biblical Theology

Harvard Theologicnl Review

International Critical Commentary

'the Institutes of the Clristian Religion

Joumat of Biblical Literaturc

Jownal of Ecclesiastical History

Joumal of the Eungelical Theological Sacioty

Jownal for the Study of the New Testament

Journal for the Study of the New Testament, Supplement

Series

Joumal for the Study of the Old Testament 


\begin{tabular}{|c|c|}
\hline JSOTStxp & $\begin{array}{l}\text { Journul for the Study of the Old Testanent, Supplement } \\
\text { Series }\end{array}$ \\
\hline$J P T$ & Joumal of Pentecostal Theology \\
\hline jR & Journal of Religion \\
\hline ITS N.S. & Journal of Theological Studies New Series \\
\hline $\mathrm{LCL}$ & Loeb Classical Library \\
\hline$M T$ & Modern Theology \\
\hline NICNT & New International Commentary on the New Testament \\
\hline NIGTC & New International Greek Testament Commentary \\
\hline NLH & New Literary History \\
\hline NovT & Nowum T'estamentum \\
\hline NPNF2 & $\begin{array}{l}\text { A Select Library Of Nicene and Post-Nicene Fathers of the Christian } \\
\text { Church. Eds. P. Schaff \& H. Wace, second series. }\end{array}$ \\
\hline NTS & New Testument Studies \\
\hline OUP & Oxford University Press \\
\hline$P G$ & Patrologia Graecn. Ed. J.P. Migne. \\
\hline$R S$ & Religious Studies \\
\hline$R T R$ & Reformed Theolugical Review \\
\hline SBL & Society of Biblical Literature \\
\hline SBLDS & Society of Biblical Literature Dissertation Series \\
\hline$S C G$ & Stmma Contra Gentiles \\
\hline SIT & Scottish Joumat of Theology \\
\hline$S P$ & Studia Patristica \\
\hline$S P$ & Sacra Pagina (commentary series) \\
\hline$S T$ & Summa Theologiae \\
\hline SVSP & Saint Vladimir's Seminary Press \\
\hline$S V S Q$ & Saint Vladinir's Seninary Quarterly \\
\hline SVTQ & Saint Vladimir's Theological Quarterly \\
\hline IB & Tyndale Bulletin \\
\hline$T T$ & Theological Intestigations \\
\hline TS & Theological Sudies \\
\hline USQR & Union Seminary Qunrterly Review \\
\hline WBC & Word Biblical Commentary \\
\hline
\end{tabular}

References to books of the Bible follow the accepted customs. Quotations and citations from 1 Thessalonians usually lack '1. Thess' before the chapter and verse number, except where this might cause confusion. Further notes about cilation style are found within the body of the thesis. 


\section{Contents}

Introduction

Part I:

The critical task

Chapter One:

1 Thesssalonians and the Historical-Critical

Project in Theological Perspective

Part II:

An exploration of some pre-modern readings of 1 Thessalonians

Chapter Two: $\quad$ Thomas Aquinas and 1 Thessalonians

Chapter Three: John Calvin and 1 'hessalonians

Chapter Four: $\quad$ Conclusion to Part 11

Part III:

A proposed reading of 1 Thessalonians

Chapter Five:

Death and Restrrrection in 1 Thessalonians

163

Conclusion

Bibliography 


\title{
Introduction
}

\section{(1) Recent scholarship on 1 Thessalonians}

I Thessalonians, like all of Paul's letters, has received much scholarly attention in recent decades. Since historical-critical interests drive much of this scholarly exertion, the question of origins remains the pervasive concern. Karl Donfried, a prominent Thessalonians scholar, articulates well the question motivating much contemporary scholarship on 1 Thessalonians,

\begin{abstract}
'What was Thessalonica like when Paul first visited and established a Christian commtunity there and what impact does this information have for understanding 1 and 2 Thessalonians? ${ }^{\prime 1}$
\end{abstract}

There have been a varicty of answers to this question. To anchor ourselves somewhere within the forest of conference papers, arguments, counter-arguments and monographs provoked by 1 Thessalonians we will focus on three seminal and prominent essays. When each of these essays appeared they moved the argument on significantly and inspired other scholars to adopt new lines of approach in understanding the original context of delivery and reception of 1 Thessalonians. As we shall see, the three essays - by Karl Donfried, ${ }^{2}$ Jolun Barclay, ${ }^{3}$ and Abraham Malluerbe ${ }^{4}$ have come to acl as nodal points within 1 Thessalonians scholarship.

Karl Donfried's signal essay of 1985, 'The Cults of Thessalonica and the Thessalonian Correspondence', did not of course arise from a scholarly vacuum. Donfried's argument, that attention to the rcligious and civic cults prominent in Ist century Thessalonica assists in understanding the letter's ethical and eschatological admonilions, is substantiated only with the help of archaeological discoveries made earlier in the century. ${ }^{5}$ Straining hard to hear the 'definite connotations for the cilizens

\footnotetext{
${ }^{1}$ Donfried, 1985,336

${ }^{2}$ Donfried, 1985. This essay has now been re-published, along with several others of Donfried's, in Donlried, 2002.

${ }^{3}$ Barclay, 1993.

${ }^{4}$ Matherbe, 1970. Malherbe's work is followed up in Malherbe, 2000; 1998; 1990; 1989; 1983.

See Vickers, 1972; Edson, 1948.
} 
of Thessalonica', Donfried attempts to place such exhortations as contained in 1 Thessalonians 4:3-8,7 within the sexual excesses associated with the cult of Dionysus. For Donfried these ethical exhortations represent Paul's attempt 'to distinguish the behaviour of the Thessalonian Christians from that of their former heathen and pagan life which is still nuch alive in the various cults of the city.'B So too, equipped with an awareness of Thessalonica's religio-political climate, is it possible to understand the politically unsettling nature of Paul's visit, testified not least in Acts 17:6-7. The Thessalonian Christians' proclamation of another 'kingdom' (2:12) and 'Lord' (2:19) would have violated the Paphlagonian loyalty oath to Auguslus and his successors. ${ }^{10}$ Political opposition to Paul's gospel thus provides the context for the Thessalonian Christians' frequently mentioned affliction and suffering,"1 a persecution Donfried extends as far as possible martyram. ${ }^{12}$

Donfried's call to pay attention to the religio-political climate of 1 Thessalonians has been enthusiastically endorsed by subsequent interpreters. Holland Lee Hendrix, consolidating the arguments of Donfried and Helmut Koester, ${ }^{13}$ reads the 'peace and security ${ }^{\prime}$ slogan of 1 Thessalonians $5: 3$ as a direct riposte and critique of prominent Pax Romana propaganda. ${ }^{14}$ Relying upon epigraphic and numismatic evidence and recent archaeological discoveries Hendrix argues that between the first century BCE and the first century CE there was a signilicant shift in the political affiliations of Thessalonica towards Rome.15 Paul's apocalyptic prediction of what would happen to those who trust the Roman assurance of pax et securitas is thus to be understood from this political context, for it is those who rely upon the might of the Roman Empire who will be the first to fall victim to the sudden wrath of God. ${ }^{1}{ }^{16}$

\footnotetext{
${ }^{6}$ Donfried, 1985,340 .

${ }^{7}$ Dontried, $1985,337$.

${ }^{8}$ Donfried, 1985, 342.

'Donfried is here largely dependent upon the work of Hendrix, 1984. In this unpublished Harvard dissertation Folland Iendrix annassed much archaeological and numismatic evidence to demonsirate the importance and popularity of Roman benefactors in the Thessalonica of the late Republican and carly Imperial period.

${ }^{10}$ Donfried, 1985, 342-4.

"] Donfried, 1985, 347-52.

${ }^{12}$ Donfried, 1985, 349-50.

${ }^{13}$ Donfried, 1985, 344; Koester, 1990, 449-50. So Kocster, 1990, 457.8, "Pattl envisions a tole for the eschatological community that presents a utopian alternative to the prevailing eschatological ideology of Rome.'

${ }^{14}$ Fendrix, 1991. So too Wengst, 1987, 87 inter alios.

1.5 Hendrix, 1991, 114-8.

${ }^{16}$ Hendrix, $1991,118$.
} 
These counter Imperial readings of 1 Thessalonians have found themselves congenial company within broader political readings of Pat1l's proclamation. ${ }^{17}$ Central to the argument that Paul is an irritant of the Imporial system is the insistence that the background of Paul's use of gospel (gủ $\gamma \gamma \gamma_{\varepsilon} \lambda_{1} \circ \nu$ ) is that the same word was associated with Imperial proclamations of victory and conquest. This is especially relevant for a letter in which the term 'gospel' has a proportionately high occurrence. ${ }^{18}$ Political readings of Paul have found expression in 1 Thessalonians scholarship most recently in J.R. Harrison's altempt to place the eschatological imagery of 1 Thessalonians 4:13$5: 11$ in an anti-Imperial, counter-cultural framework. ${ }^{19}$ like the work of Donfried, which can be understood as its forefather, J.R. Harrison re-constructs the allusions and conutations, as the letter's original audience would have heard them. Just as for Donfricd, Harrison's driving concern is to understand the hostile response of the Romans, as evidenced in Acts 17:7.20 Harrison argues that Paul's choice of words and phrases throughout 1 Thessalonians, with their constant Imperial allusions, are 'a radical subversion of Roman eschatological imagery and terminology. ${ }^{21}$ Sensitivity to the letter's Imperial context persuades us of Paul's intention: to demonstrate the superiority of the risen and retuming Christ as compared to worldly, yet dominant, Imperial eschatologies.

John Barclay's essay, 'Conflict in Thessalonica', shares much in common with these 'political' readings of 1 Thessalonians, insofar as his prime interest is 'the conflict in Thessalonica between Christians and non-Christians. ${ }^{\prime 22}$ Barclay's careful analysis of the likely causes of conflict in Thessalonica steers away from Donfried's tentative suggestion that some Thessalonian Christians died for their faith..3 Rather, the

\footnotetext{
${ }^{17}$ e.g. Horsley, 2000; 1997; Khiok-Khng, 1998; Lassent, 1991; Wright, 2000; 1994.

${ }^{18}$ Donfried, $1996,397$.

19 Harrison, J.R., 2002. In arguing that the best context with which to understand the eschatological admonitions of 1 Thessalonians is the contenporary Imperial propaganda Harrison, J.R., 2002, 72-6, thus dismisses the other scholarly suggestions that have attempted to account for the letter's eschatology. Various contexts for Paul's admonitions have been suggested: Schmithals, 1972, 123-218, has suggested that Paul was writing against Gnostics who had spiritualised belief in the resurrection; Bruce, 1982 , xxxvii, has suggested that so short was Paul's time in Thessalonica that the Thessalonian Christians remained ignorant about the full implications of Christ's resurrection; Mearns, 1980-1, 137-51, and Jewett, 1986, 1.42-7, have proposed that the Thessalonians had an over-realised cschatology, and so were especially traumatised at the dealh of fellow believers; and Jowett, 1986, 127-32, has also suggested that Patl is polemicising against the cult of Cahirus.

${ }^{20}$ Harrison, J.R., 2002, 78.

${ }^{21}$ Harrison, J.R., $2002,92$.

${ }^{22}$ Barclay, 1993, 512.

${ }^{23}$ Barclay, 1993, 514 n.6.
} 
suffering froquently mentioned in 1 Thessalonians is best understood as 'social harassment',24 cmanating from fellow Gentiles angered by those who had abruptly shumed 'normal social and cultic activities' as a consequence of their conversion to Christianity. ${ }^{25}$

John Barclay's essay is important, not just because it provides a refinement of the excesses cvident in Donfried's and Robert Jewett's work on 1 Thessalonians, ${ }^{26}$ but also in the overtures it makes to social-scientific study of the letter. After examining the likely causes of the social conflict in first-century Thessalonica, Barclay examines the letter's dualist apocalyptic symbolism, and argues that if we are aware of the Thessalonians' sense of social dislocation, then 'it is obvious how experience and symbol will reinforce each other.'27 The apocalyptic contours of 1 Thessalonians are thus best understood if we are sensitive to the social implications of the 'Thessalonians' traunatic conversion. ${ }^{28}$ In the conclusion, however, Barclay states explicitly what has been implicit throughout, his tentative interest in applying sociological models to the Thessalonians' conversion experience. Citing the influence of Louis Coser's The Functions of Social Conflict, Barclay states that, 'opposition from outsiders can serve a beneficial function in defining the boundaries of a group and reinforcing its boundaries. ${ }^{29}$

Barclay's overtures to applying social-scientific approaches to study of 1 Thessalonians are eagerly taken up by Todd Still and Craig S. De Vos. The work of these two scholars, in which sociological models of conflict are applied to the study of 1 Thessalonians, demonstrates the clear influence of John Barclay. ${ }^{30}$

Todd Still's Conflict at Thessalonica: A Pauline Church and its Neighbours is explicitly concerned with recovering the nature of the suffering experienced by Paul's converts in Thessalonica, an instance of inter-group conflict which he proposes can be

\footnotetext{
${ }^{24}$ Barclay, 1993, 5 I4.

${ }^{25}$ Barclay, 1993, 515 ,

${ }^{26}$ Jewett, 1986.

${ }^{27}$ Barclay, 1993, 518.

${ }^{28}$ Barclay, 1993, 519, 'the npocalyptic contours of Paul's message sland out as a rcady cxplanation of their thlipsis and provide the necessany mens for enduring it.'

${ }^{29}$ Barclay, 1993, 529 .

${ }^{30}$ De Vos, 1999, 1, 156 passin; Still, 1999, 17, 198, 209-14, 223.5 passim. A number of Barclay's other essays, similar in theme to the one we have discussed, are enthusiastically cited by both De Vos and Still, not least Barclay, 1995; 1992.
} 
understood best through the lenses of social-scientific study of deviance and conflict.31 The influence of John Barclay's work on the social situation in Thessalonica is cvident throughout Still's monograph. ${ }^{32}$ For Still, the apocalyptic tone of 1 Thessalonians is Paul's polemical response to the social dislocation both he and his converts were experiencing; 33 the Thessalonian Christians would have been 'ostracized by nonChristian family, friends and associates for joining an upstart movement ${ }^{\prime} ; 3$ and like Barclay he argues that the suffering of the Thessalonians emanated exclusively from fellow Gentiles, and not a group of townspeople that might have included Jews. ${ }^{35}$ Likewise, in broad sympathy with Barclay's thesis, Still locates the source of this Gentile opposition in their suspicion that conversion to Christianity was 'subversive to the fotndational institutions of Greco-Roman socicty, namely, family, religion and government.'36 Todd Still's more obviously independent contribution lies in his awareness of social-scientific study of intergroup conflict, and his applicalion of this to the situation of external opposition portrayed in 1 Thessalonians. The conflict endured by the Thessalonian Christians, Still argucs, had three effects; it reinforced the faith of the afflicted Christians; it strengthened congregational relations; and it served to heighten their eschatological hope in Christ's return.;

Craig S. De Vos' Church and Community Conflicts: The Relationships of the Thessalonian, Corinthian, and Phitippian Churches with Their Wider Civic Communities demonstrates an equal indebtedness to Barclay's 1993 essay (as well as Barclay's 1992 essay). De Vos' aim is to draw on social-scientific theory to explain why some of Paul's churches experienced conflict with outsiders, whilst others did not: ${ }^{3}$ Where Still gives a fairly broad overvicw of social-scientific study of intergroup conflict; 39 De Vos examines social-scientific theories of the development of conflict in Mediterranean societies,

\footnotetext{
${ }^{31}$ It is thus very important to Still that the suffering endured by the Thessalonians is not psychological, but involves some real level of physical harassment, something he atgues for in Still, 1999, 209-17. Still is thus arguing against Malherbe, 1989, 73, for whom the Thessaloniaus' suffering could be understood as 'pyschological trauma, tiscouragement, grief, uncertainty about the implications of the new faith for everyday life, and dislocation from the larger society.' See also Mallerbe, 1998.

${ }^{32}$ Barclay's 1993 essay is cited some 35 times by Still in the course of his monograph.

${ }^{33}$ Still, 1999, 197, 206. Cf. 13arclay, 1993, 516\%20.

${ }^{34}$ Still, 1999, 214. Cf. Barclay, 1903, 515.

${ }^{35}$ Still, 1999, 218-27. Cf. Barclay, 1993, 514.

${ }^{36}$ Still, 1999, 228-267 (267). Cf. Barclay, 1993, 515 .

${ }^{37}$ Still, 1999, 268-86.

${ }^{38}$ De Vos, 1999, 5-8. The contrast De Vos presumably has in mind here is that of the difterences in social integration between the Thessalonian and Corinthian Christians, noted by Barclay, 1992.

${ }^{39}$ Still, 1999, 107 24.
} 
investigating why conflict might experience varying intensilies in different contexts. ${ }^{40}$ De Vos argues that Greco-Roman cities, with their high degree of socialisation, can be classified as Gemeinschaft-types of community, ${ }^{4+}$ those more likely to experience conflict.42 The differences between Greek and Roman societies in conflict response can be traced to divergent approaches and attitudes towards religion. ${ }^{43}$ Consolidating his argament with a comparison between the social-structural composition of Greek and Roman cities,4 De Vos proposes that Greek communities represent a higher conflict culture compared to the lower cotflict culture of Roman commutuities (allhough both being Mediterranean represent a high conflict culture). De Vos successively reconstructs the nature of first-century Thessalonica and the Christian community established by Paul before examining the 'sevcre conflict' between the church and its civic neighbours. 45 This high level of conflict can be linked to Thessalonica's status as a sivitas libera and a correspondingly dominant Greek mentalily in terms of political structure and religious practice. The high level of conflict experienced in Thessalonica can be traced to a combination of Thessalonica's norms, values and beliefs; the lack of cross-cutting ties or ethnic integration within the 'l'hessalonian church; and the Thessalonian Christians' impotence within the wider political structures of the city. ${ }^{4 h}$

Abraham Malherbe's essay, "Gentle as a Nurse": The Cynic Background to 1 Thess ii', decisively interrupted hitherto dominant interpretation of 1 Thessalonians 2:1-12. For many decades these verses had overwhelmingly been read as apologetic, though there was little agreement about whether Paul was defending himself from specific attacks of either Jewish or Gnostic opponents.47 There had been some occasional lone voices, not least that of Martin Dibelius in 1937, who proposed that Paul was drawing on

\footnotetext{
${ }^{10}$ De Vos, 1999 .

${ }^{41}$ De Vos is drawing upon the sociology of Tonnies, 1\%. 1957. Community and Society: Genteinschaft and Gesellschaft. East Iansing: Michigan State Universily Press. De Vos, 1999, 14-15, defines a Gemeinschaft as, "characterised by relationships that are intimate and face-to-face, involve reciprocily, paternal authority, mutual assistance, concord and group loyaly....As such it has an innate unity which presupposes shared customs, beliefs, mores, a traditional religion, a common understanding of good and evil, and common friends and enemies.'

${ }^{42}$ De Vos, $1999,28-42$.

${ }^{43}$ De Vos, 1999, 42-86.

${ }^{44}$ De Vos, 1999, 87-116.

${ }^{45}$ De Vos, 1999, 123-77 (176).

${ }^{46}$ De Vos, $1949,292-300$.

${ }^{47}$ For the former view see Milligan, 1908, xxxi-xxxii, and lirame, 1912, 9-10; for the latter view see Schmithals, 1972, 123-218 (a trauslation of the 1965 German original).
} 
examples of wandering Cynic philosophers who held up as a paradigm their selfless behavioutr.43

Malherbe's fuller exposition of this thesis in his 1970 essay has now come to represent an influential riposte against apologetic readings of 1 Thessalonians 2:1-12 and thus against reading the text always as a foil to an event lying behind it. Malherbe exposes the similarities in langtrage and style between Paul and the Cynic philosopher. Dio Chrysostom's (40-120 CE) Alexandrian oration in which he sets out the qualities of a true philosopher. Crucial for the thesis Malherbe is trying to draw out of this parallel is that in Dio's oration there is 'no question of his [Dio] having to defend himself here against specific charges that he was a charlatan.'49 Rather Dio's aim is to illustrate the kind of preacher he is, by comparing himself to other Cynic philosophers, many of whom he denigrates. Malherbe demonstrates how 'strikingly similar' are Dio's critical depiction of Cynic preachers and Paul's antithetical description of his own behaviour in Thessalonica. ${ }^{50}$ Many of these similarities demonstrate compelling lexical parallels. ${ }^{51}$ If these parallels convince us it is not beyond reason to use Dio's context in helping us understand 1 Thessalonians 2,

'One is not obliged to suppose that Dio was responding to specific statements that had been made about him personally. In view of the different types of Cynics who were about, it had become desirable, when describing onesell as a philosopher, to do so in negative and antithetic terms. This is the context within which Paul describes his activity in Thessalonica. We cannot detemine from his description that he is making a personal apology. ${ }^{52}$

Malherbe's argument is that Paul is not responding to a specific complaint but is drawing tipon traditional motifs used in discussion of Cynic preachers. In subsequent

\footnotetext{
${ }^{48}$ Dibclius, 1937, 7-11. See Weima, 1997, 75.

${ }^{49}$ Malherbe, 1970, 205 (emphasis added).

50 Malhcrbc, $1970,216$.

is Malherbe, 1970, 216-7.

52 Malherbe, $1970,217$.
} 
articles Malherbe has demonstrated Paul's paraenetic intentions in providing the Thessalonian Christians with a self-depiction worthy of imitation..$^{53}$

Malherbe's thesis has been broadly well-received, and coupled with the recent enthusiasm for rhetorical readings of Paul's letters, $r^{54}$ there has been a general shift away from 'apologetic readings' of 1 Thessalonians 2:1-12. With now just a few voices of dissent, ${ }^{55}$ most scholars are convinced that in 1 Thessalonians 2:1-12. Paul's intention is to present 'his own apostolic lifc, as a model to be emilated by the congregation.' Where at one stage antithetical statements were read as mirrors of polemical situations, Malherbe's essay signalled a scholarly shifl away from the 'reconstuction of unverifiable data behind the text', and towards that which is only 'explicitly offered by the text', 57

\begin{abstract}
the antithetical style used in 2:1-12 does not necessarily mean that the views that are on the 'not...' side of the antitheses acltally exist: opponents are an tunecessary hypothesis.' 55
\end{abstract}

These three essays, by Karl Donfried, John Barclay, and Abraham Mallerbe, represent highly significant contributions to recent Thessalonians scholarship. They are important, not just for the new perspectives they have provided on 1 Thessalonians, but for the impetus they have given to subsequent political, social-scientific, and rhetorical readings of Paul's letter. Moreover, they are contributions representative of the diverse field that is contemporary Pauline interpretation.

\footnotetext{
${ }^{53}$ Malherbe, 1990; 1989; 1983. Malherbe has re-stressed his position most recently in Malherbe, 2000, $81-6,153 \cdot 6$.

${ }^{54}$ See the essays in Donfried and Beuller (eds.), 2000. Walton, 1995, 230-40, discusses rhetorical critictl study of 1 Thessalonians. For the popularity of thetorical criticism of the Pauline literature, see Ilansen, 1992.

55. Holtz, 2000, argues that there is a real situation 'behind' the language of 1 Thessalonians $2: 1-12$, and that it can be plausibly argued that the situation Paul was responding to was the potentially grave consequences of 'a thegative propaganda campaign that aimed to destroy his work by attacking his person' (79). See also Weima, 2000; 1997 (discussed in chapter 1); Barclay, 1993, 513 ; Donfried, 1989, 258-9; Bruce, 1982, 27.8 .

${ }^{36}$ Merk, 2000, 112. For those broadly convinced of Matherbe's thesis sce Watson, D.F, 1999, 67-8; Gaventa, 1998, 25-6; Richard, 1995, 88-9; Smith, A., 1995. 78-9; Hughes, 1990, 101-2; Wanamaker, $1990,46-8,54$.

${ }^{57}$ Vos, 2000,82 .

${ }^{58}$ Walton, 1995, 244 (emphasis added).
} 


\section{(2) Theological interpretation of Scripture and interest in Wirkungsgeschichte}

Despite all this scholarly exertion, of which we have provided only a brief glimpse, there are still lacurae in the study of 1 Thessalonians. One such gap, which this thesis proposes to meet, is the epistle's theological interprefation. To be sure, there have been attempls to exposit the epistle's theology. ${ }^{59}$ Without presaging the critique presented in chapter 1 , it suffices to say that such theological of ferings have remained stubbornly tied to regnant historicat-critical modes of reading. Correspondingly there has been a notable silence in exposing theological treatments of 1 Thessalonians to either the text's history of interpretation or to (broadly) systematic catcgories of theological thought. This might seem unstrprising were it not both for the recent emergence of interest in the Bible's history of interpretation and use (the two as we shall observe are slightly different), and the prominence and volume of those advocating a closer relationship between the disciplines of Biblical studies and systematic theology. Study of 1 Thessalonians has stood stubbonly aloof from both these academic currents.

Literature on both of these academic trends is voluminous. Within the Iast decade a number of scholars have argued for a closer relationship between theological categories of thought and Biblical studies.61) These appeals have emanated from both the guild of Biblical scholars, ${ }^{61}$ and systematic theological colleagues, ${ }^{62}$

Alongside this growing interest in the perceived need for systematic theology and Biblical scholarship to work more closely has been a growing awareness that one of the more interesting aspects of the Scriptural text is its life after it has left the pen of its author. A variety of scholars have called attention to this aspect of the Biblical text's

\footnotetext{
${ }^{59}$ Donfricd, 1993; 1989; Bassler, 1991b; Richard, 1991; Marshall, I.F., 1982.

${ }^{60}$ The work of Watson, F., 1997; 1996; 1994a; 1994b, remains a most distinguished contribution in this school of thought. Green, J.B. \& Turner, M. (eds.), 2000; Moberly, 2000; Barton, S.C., 1999; Fowl, 1998, also represent important contributions. In sceking to relate the endeavours of Biblical scholars and theologians more closely such scholars are, of course, working against the grain of entrenched assumptions about the importance of keeping separate dogmatic questions fiom the assumed historical task of exegesis. 'This trend can be traced back to J.P. Gabler's famous lecture of 1787, in which he attempted to keep apart theological intercsts from un early "listory of religions" approach. See SandysWunsch, $J$. and Eldredge, L. 1980. Răisänen, 1990, provides a robust defence of a strictly historical approach to New Testament stukly. Davies, F.R., 1995, also provides a trenchant critique of attempts to relate Biblical studies to theological questions.

61 e.g. Bockmuchl, 1998, 295-302; Chilis, 1997; 1995.

${ }^{62}$ e.g. Wehster, 1998; Lash, 1985.
} 
historicity, ${ }^{13}$ as readings capable of casting new perspectives on the text's ambiguities and richness of meaning, ${ }^{64}$ and of providing a 'hermenettical bridge from the world of the text to the world of the Christian reader and his or her comminity.' 65 Three German terms, all of them broadly within this school, are used to refer to three different areas of interest: Wirkungsgeschichte (history of effects); Auslegungsgeschichle (interpretation history) ${ }^{66}$ and Rezeptionsgeschichte (reception history). ${ }^{67}$

This growing interest in the Bible's meaning and significance in the light of its reading and impact throughout history manifests itself in different forms. 'The comunentaries of Ulrich Litz on Matthew, ${ }_{r}^{68}$ and Anthony Thiselton on 1 Corinthians, ${ }^{\text {(19 }}$ have sought to incorporate insights from the text's use and influence within their comments on the text. Allied to this is the Ancient Christian Commentary on Scripture series edited by Thomas C. Oden, which has translated and made available a wide selection of Patristic exegesis. Margaret Mitchell has recently offered a monograph on Chrysustom's exegesis of Paul.70 A new commentary series to be published by Blackwell promises 'a genuinely new approach in... [its] cmphasis on the way the Bible has been used and interpreted through the ages, from the church fathers through to current popular culture, and in spheres as diverse as art and politics, hymns and official church statemenls. ${ }^{71}$ Interest in the Biblical text's afterlives - whether in the medium of relatively élite literature or through more diffuse cultural representations - is undeniably in ascendancy.

\footnotetext{
${ }^{63}$ e.g. Bockmuchl, 1998, 295-8; 1995; Luz, 1994; 1990; Riches, 2001; 1994. So Luz, 1994, "The history of effects....cannot be separated from the texts, because it is an expression of the text's own power. It belongs to the texts in the same way that a river flowing away from its source belongs to the sourcc.'

${ }_{64}$ Richcs, 1994, 348, "The meaning of texts can no longer simply be identified with one single, authorial sense: the plain meaning of Scripture.... What is interesting about texts is not just their intended sense... but rather their power to generate a rich set of meanings to different communities at different times.' So also Luz, 1990, 99, 'texts are full of possibilities of application which do not exclude ench olher.'

${ }^{65}$ Bockmuehl, 1995, 87.

${ }^{66}$ Bockmuehi, 1995, 61-2, notes the subtle distinctions between a text's interpretation in the commentary and exegetical tradition of the church, and the text's wider ecclesial and extra-ecclesial impact. Although the two - Auslegungsgeschichte and Wikungsgeschichte - are often hard to separate, it is nevercheless useful to rctain a distinction hetween these aspects of the text's historicity. A good example of a text, whose history of interpretation and history of effects are distinct, though related, is Romans. See Morgan, $1995,128-51$.

${ }^{67}$ The subliile of Iuz's 1994 book outlines these three areas of interest: interpretation, influence and effects.

${ }_{618}^{18} \mathrm{Luz}, 1990$.

${ }^{69}$ Thiselton, 2000, esp. xvii, 196.

${ }^{70}$ Mitchell, M.M., 2002. Wiles, 1967, offered an curlier and much broader study of Patristic exegesis of Paul. See also Hroehlich, 1996.

${ }^{71}$ Blackwell's website (http://www blackwellpublishing.com).
} 


\section{(3) The contribution of this study}

In this broad depiction of scholarly activity where does our contribution lie? Firstly, and most importantly, this thesis endeavours to make a contribution towards understanding 1 Thessalonjans. In. this sense the constantly stable clement of our labours is the 91. verses that make up this earliest exlant Christian text. Choosing to focus on this text we inescapably become part of its ongoing interpretation, some of whose recent trends we have sketched above.

If the text of 1 Thessalonians is the focus of attention throughout this thesis, the constant mode of our interpretation is theological. This is a thesis that attempts to make a contribution within the growizng project of relating Biblical studies more closely to theological concerns. As one commentator sympathetic to the Austegungsgeschichte states, 'the widespread rejection of theological interpretation in conlemporary exegesis is a most extraordinary self-inflicted wound ${ }^{\prime}{ }^{72}$ and it is with that similar conviction that we will offer an interpretation of 1 Thessalonians that constantly interacts with 'systematic' theological categories of thought. ${ }^{73}$

Two theological leitmotios recur implicilly and explicitly throughout the interpretations of the text we successively critique (I'art I), explore (Part II), and propose (Part III). These leitmotios guide and direct the shape of the thesis as a whole. The first leitmotiv is the conviction that in 1 Thessalonians we are reading the issue of an apostle, and hence words of witness pointing to a reality calling for ever deeper attention and exploration. The second leitmotiv is that the revelation of God in Christ is a ceaselessly profound well of meaning, a depth and potential plumbed in the church's reading of its Scripture. As this thesis progresses, the witness of the text will be accumulatively glimpsed, discerned and explored, as something that enterges from attention to the text's interpretation hislory, an interpretation hislory siluated within our understanding of revelation.

\footnotetext{
${ }^{72}$ Riches, 2001, 261 .

${ }^{73}$ Inverted commas are placed around systematic, becausc one of the major themes of this thesis is a marked unease at the balkanisation of the Christian theological cndeavour. The fragmentation of theology - a symptom of its protessionalisation within the context of post-Enlightenment universities - is a cause for regret, insofat as the various ways of thinking and exploring theologically (be they "systematic" or "Biblical') are directed towards the understanding of God revealed in Christ. In this sense, given its subject matter, Christian theology's tendency to fragment into a myriad of disciplines, who come to forget their mutual relations, is a fateful step.
} 
The importance of 'witness' and the text as an agency within the 'process of revelation' arise from the reading of two of the most important conversation partners of the thesis: Kanl Barth and Dumitru Stăniloae. It is these theologians who have indicated the potential of grappling with the 'witness' character of Paul's writing and the conception of revelation, in which Scriptural exegesis plays its part, best understood as an eschatological momentum.

From the wrork of Karl Barth (1886-1968) we have become convinced of the importance and urgency of wrestling with the miracle of witness within the words of Scripture, that aspect of the text which radically points away from itsclf and wills the transformation of its readers. This hermeneutical aspect of Karl Barth's theological exegesis has been well documented in tecent secondary literature, ${ }^{74}$ and will be enthusiastically followed through in our attempt to understand Paul's thought. For Barth, Paul was above all a witness to revelation, and if we are to understand him we must prepare to be gripped by what Paul was gripped by in order to glimpse that to which Paul was pointing. It is from within this commitment to Paul as an apostle, as one who sees things that we could not see for ourselves unaided, ${ }^{75}$ that the thorny question of authorial intention is properly placed. Understanding Paul as author is less a question of understanding his putative authorial intention, and far more a question of comprehending (if not allowing ourselves to be comprehended by) the object Paul is willing us to perceive. The climactic aim of this close reading Barth proposes is for the witness to miraculously become the Word,

'The prophet, the man of God, the seer and hearer, ceases to be, as that to which he unwaveringly points begins to be. ${ }^{.76}$

Barth's plea to cncounter the miraculous witness of the Bible, with what the text is really pointing to, is an important theme throtghout this thesis. An equally important theme infiltrating our encounter with the text's history of exegesis (in Thomas, Calvin, and others) is that revelation is best approached as an eschatological dynamic, a momentum discerned in the church's task of unfolding the meaning of Paul's wilness.

\footnotetext{
${ }^{71}$ Burneti, 2001; Jeuniond, 1988; Jungel, 1986; McCormack, 1991; 2002; Provence, 1986; Watson, F., 2000; 2002; Wharton, 1972.

75 'Biblical Questions, Insights and Vistas' in Barth, 1957, 51-96 (63).

76. 'Biblical Questions, Insights and Vistas' in Barth, 1957, 51-96 (75).
} 
It is here where the thought of the Romanian Orthodox theologian Dumitru Staniloae (1903-1993) has been influential. The profundity of Dumitru Stăniloae's thought is only slowly being realised in the West,77 aithough he has been compared to such theological luminarics as Karl Rahner and Karl Barth. ${ }^{78}$ Dumitru Stăniloae's theological style, needless to say, is somewhat distinct from that of Karl Barth's. Imbued in the Fathers (not least the cosmic vision of the seventh century Byzantine theologian, Maximus the Confessor) ${ }^{79}$ Staniloae's thought is spiritual to its core, a reminder that 'theology is nothing else than an existential expression of the Spirit's life offered to God', 80

\begin{abstract}
'Theology fox him means freedom from both enslaving passions and intellectual idols. It is doxological; its symbolic language evokes the language of prayer. It is an intellectual liturgy centred on the revelation of the Foly Trinity. It takes place in an act of personal invocation and communion with God; therefore prayer is the gate of theology.'s1
\end{abstract}

Stainiloae's theology, ccntred on the cosmic transfiguration manifest in the incarnation, creatively interplays God's transcendence and his involvement within the world, or between the necessarily apophatic and cataphatic elements of theology, and as such it is no surprise that Stäniloae's thought contains much reflection on revelation within the ongoing life of the church. For Staniloac, the revelation of God in Christ is the central mystery of the world, and the source from which the power which continually maintains the divine life in the church unceasingly springs. 82 The event of the incarnation is, for Stäniloae, the dynamic pulling together of the infinite God wilh

\footnotetext{
${ }^{77}$ For introductions to Stătoiloac's thought see Miller, 2000; Louth, 1997; Bria, 1981. For an introduction to the more personal context of Dumitru Stăniloae's thought and writing, see Meyendorff, 1980. Stăniloae's work is slowly being translated from the original Romanian into English. The work of major importance for us remains the Enylish first volume of his Teologia alogrnatica orlodoxa (Stănilone, 1994) and Stăniloae, 1980, which is a translation of a number of articles originally published in Romanian joutnals.

${ }_{78}$ e.g. Brial, 1981, 53.

79 Louth, 1997, charts the intellectual influences upon Stăniloae's thought, positioning hirn broadly within the Neo-Patristic synthesis represented by other such Orthodox theologians as Georges Florovsky and Vladimir Lussky, but notes that his thought contains 'little real engagement with Western theology' (261).

${ }^{80}$ Btia, 1981, 59 .

${ }^{81}$ Bria, 1981, 55 .

${ }^{82}$ Stüniloae, 1986, 53.
} 
finite humanily, a communication of 'the infinite spiritual richness of $\operatorname{God}^{\prime}$, 83 an encounter whose meaning is unfolded in the dynamic, progressive life of the church schooled to see the divine will within the form of the world's apparent opaqueness,

\begin{abstract}
'God in himself is a mystery. Of his inner existence nothing can be said. But through creation, throtigh providence and his work of salvation, God comes down to the level of man...Touching our spirit he wakens in us thoughts and words which convey the experience of his encounter with us. But at the same time we realize that our thoughts and our words do not contain him completely as he is it himself...Our words and thoughts of God are both cataphatic and apophatic, that is, they say something and yet at the same time they suggest the ineffable. If we remain enclosed within our formulae they become our idols; if we reject any and every formula we drown in the undefined chaos of that ocean. Our words and thoughts are a finite opening towards the infinite, transparencies for the infinite'.84
\end{abstract}

Stăniloae's conception of theology as an unceasing exploration of the mystery of God's will in Christ, revealed in Scripture, and sustained by the church's historical reflection on 'the content lying within' Scripture, ${ }^{85}$ provides a central insight for the shape of this thesis.

These conceptions of Paul's text as a witness to revelation, and revelation as an eschatological dynamic expanding through time, under-gird the thesis as a whole, as it moves in Part I to critique historical-critical readings of 1 Thessalonians, to explore in Part II the 'interpretation history' of the text in the specific instances of Thomas Aquinas (1224-75) and John Calvin (1509-64), and to propose in Part III our own theological reading of the text. In this sense, the thesis is an exploratory atternpt to

\footnotetext{
83 Stăniloae, 1986, 54.

84 'The Holy Trinity: Structure of Supreme Love' in Stăniloae, 1980, 73-108 (73).

85 Miller, 2000, 46.
} 
follow through with utter seriousness the witness of the text, a witness that only begins to emerge through careful reading of Thomas and Calvin. si $^{\text {. }}$

Part I of the thesis prosents a theologically informed critique of dominant strands in the historical-critical interpretation of 1 Thessalonians. Whilst constantly seeking to work with models of Biblical interpretation as it is in practice deployed and defended, we will likewise engage with the theological and hermeneutical concepts of revelation and conversation. Particularly important to the formation of the thoughts in chapter 1 is the work of the aforementioned Karl Barth and Dumitru Starniloae, but also the theologians David Brown and David Tracy. Working alongside and with instances of Biblical scholarship on 1 Thessalonians, we shall propose that historical-criticism can be critiqued from three perspectives: that it operates with a restricted notion of meaning and truth; that its historicist tendencies tends to limit the dynamic potential of Scripture's language; and that historical-critics are vulnerable to readings which completely miss the subject matter of the very texts they are studying.

The final conclusion of Part I leads naturally on to the task of Part II, which is to explore the under-utilised commentaries of Thomas Aquinas (1224-75) and John Calvin (1509-64). Our study of these two readers of the text is correctly viewed from the perspective we have set out on the process of revelation wilhin the church (above, and in Part I in sustained detail). ${ }^{\mathrm{g}}$ Responsible to the historical context and hermeneutical devices of both of these pre-modern commentators we are equally attentive to their polential in helping us explore the depth of 1 Thessalonians. Our turn to the text's history of interpretation, in particular its pre-modern interprefation, is motivated both by the search for new methodological tools with which to read 1 Thessalonians (in the light of our dissatisfaction with historical-criticism) and the quest for the text's witness.

Consequently, it is argued that in Thomas' commentary the causality of Christ's resturrection forms the climax and pivotal guiding point, a Christ-driven exegesis

\footnotetext{
${ }^{86}$ Throughout this thesis, we shall be deploying such terms as 'witness', 'ultimate reality', 'subject matter' as virtual synonyus to indicate our interest in the substance of what the text is ultimately trying to communicate and, hence as theologians, what requires our attention.

${ }^{87}$ Raisănen, 1992, provides an important l'eminder that study of a text's history of interpretntion need not always be a project with theological aims in sight, as it very much is in our construction.
} 
which we will be keen to explore and expand in our own theological reading of the lext. Calvin's exegesis is, unsurprisingly, somewhat different in style, but nevertheless offers th the vision of exploring the whole of 1 Thessalonians from an eschatological perspective which works with the dialectic of the future's transcendence and salvation as a principle already at work in the world.

Taking on board the hermeneutical and interpretative insights of these pre-modern voices on the text, in Part III we move to propose our own theological reading. The distinguishung characteristic of this part of the thesis is a commitment to the text itself, and the understanding of the text through a historically informed vision. Consequently, not just the insights of Thomas and Calvin are aids to the proposed reading of 1 Thessalonians. Equally impurtant in the theologically driven (or better, Christ-driven) exegesis we offer in this part are numerous Patristic voices on the meaning and significance of the union of God in Christ. The attention paid to these voices should be read as our attempt to explore alongside them the infinite depth contained within Scripture. Especially important to the conversation we construct arotund the depth of 1 Thessalonians are Patristic figures most associated with Eastern Orthodoxy: Origen (c.182-251 CE); Athanasil1s (c.296-373 CE); Gregory Nyssen (c.334395 CE); Gregory Nazianzen (c.325-389 CE); Cyril of Alexandria (c.376-444 CE); Maximus the Confessor (c.580-662 CE); John Damascene (c.675-749 CE) and Gregory Palamas (c.1296-1359).88

Other voices we shall consult in proposing a reading of 1 Thessalonians' witncss are the previously examined contributions of Thomas Aquinas and John Calvin, alongside contributions from Karl Rahner (1904-1984), Karl Barth and a host of other theologians and Biblical scholars. These are all notably eclectic voices, and our intention in convening them is not in any way to ignore the very real differences amongst their starting points and conclusions. The aim is neither to pretend that these differences do not exist, nor to blend these voices into some flavourless cocktail, but rather to listen to their disparate contributions as a richness appropriate to the infinite depth of 1 Thessalonians. This is a project whose coherence and viability is best seen in its actual practise.

\footnotetext{
88 ' 1 'he texts consulted and secondary literature are listed where appropriate.
} 
After garnering hermeneutical insights from Karl Roluner, the central drive of this part of the thesis will be to explore in their infinite depth the imnges of redemption presented in 1 Thessalonians, most cspecially the apostolic witness that, 'since we believe that Jesuls died and rose again, even so, through Jesus, God will bring with him those who have died.' (4:14).

By the time this thesis theologically driven reading of 1 Thessalonians reaches its conclusion it should be clear that the structure of this project is somewhat different from still dominant historical-critical modes of reading the Bible. This is patent not just from Part I, bul equally from our study of the contributions of Thomas and Calvin, voices examined to help us garner the wealth of meaning contained within 1 Thessalonians. Rccalling the all-important nature of the Bible's witness, and the infinite capacity of revelation, there is a sustained attempt in this thesis to show the possibility that in the 89 verses of our focus there resides an ultimate reference of boundless depth,

'the Bible is an entire universe, it is a mysterious organism, and it is only partially that we attain to living in it. The bible is inexhaustible for us because of its divine content....by reason, also, of our limited and changing mentality. The Bible is a heavenly constellation, shining above us eternally, while we move on the sea of human existence. We gaze at that constellation, and it remains fixed, but it is also continually changing its place in relation to us.' 89

${ }^{89}$ Buigakov, 1935, 31. 


\section{Part I}

The critical task 


\section{Chapter One: 1 Thessalonians and the Historical-Critical Project in Theological Perspective}

\section{Introduction}

Historical-criticism's assumed control over the reading of 1 Thessalonians is best challenged as it is actually practised, deployed and defended. Throughoul this chapter therefore we will analyse and critique instances of historical-criticism, especially as they pertain to scholarship on 1 Thessalonians. Through these critiques, it is hoped that our distinct theological perspectives will begin to cmerge. It is these theological perspertives, only partly forged in negative reaction to historical-criticism, which will be worked out practically in the readings of 1 Thessalonians that comprise the remainder of the thesis.

This chapter will be composed of the following sections. To prepare ourselves theologically and hermeneulically for the ensuing critiques and proposals we will initially examine thee important concepts implied throughout our work: historicism, revelation, and conversation (\$1). We shall then be ready to launch our theologically driven critique of historical-criticism by examining the work of two distinguished historical-critical scholars, James Dunn and Karl Donfried (\$ 2). The burden of section 3 will be to set out three specific charges that will be made against historical-crilicism. These critiques will be advanced in relationship to specific instances of 1 Thessalonians scholarship and should be understood as something of a triad, as each belongs closely with the others. The first charge is that historicalcritical studies operate with a limited notion of meaning and truth (\$ 3.1). The second charge is that historical-criticism is disabled by a historicism that fixes language into a restrictively reflective relationship between text and original context (\$ 3.2). The third charge is that the historicism within historical-criticism distracts historical critics from the actual subject matter of the Biblical texts ( $\$$ 3.3). The conclusion (\$ 4) will prepare the way for the subsequent chapters of the thesis. 


\section{(d) Historicism, revelation and conversation}

Before proceeding any further it is necessary to set out some preliminary definitions of three theological and hermeneutical terms we shall be deploying (implicitly and explicitly) throughoul our thesis. These three terms are: historicism; revelation; and conversation.

\section{IIistoricism}

One of the charges we will frequently make against Biblical scholars is that they are often disabled by a silent, or not so silent, historicism. This is a term we will have to explain, not least because amidst the variety of ways in which this term has been and is used, our use might be read as idiosyncratic. We are aware of the variety of historiographical, philosophical and literary schools of thought that have adopted the term 'historicism'.1 In its own complex history of interpretation, 'historicism' as a term has been consistently intermeshed within prevailing ethical, philosophical and political debates. ${ }^{2}$

Historicism, as we identify it within Biblical scholarship, is an assumption that the meaning of what the Bible communicates, through its diverse literary genres, is basically recoverable by examining the text's particular historical context. The historicism we are opposing is, above all, one that de-limits and restricts the meaning of a text by retreating to the authority of a 'neutral' historical meaning. Such a perspective militates against both the timeless capacity of the Biblical texts as classics (the extent to which their status now is a record of their ability to speak apart from their context of production) and their revelatory potential (the extenl to which they continue to speak to the church). This is how James Barr has defined historicism:

'historicism is the idea that, in order to tunderstand something, the essential mude is to get at its origins. The historicist is never satisfied with the thing as it is, he or she has to anderstand it by discovering the past. ${ }^{3}$

\footnotetext{
${ }^{1}$ See Iggers, 1995; Morgan, 1990; Lee \& Beck, 1954.

${ }^{2}$ Lee \& Beck, 1954, 575.

${ }^{3}$ Barr, 1996, 106.
} 
Barr's focus on the historicist's dissatisfaction 'with the thing as it is' is crucial. The historicist is never content to read the text as it stands. For the historicist the only way to understand the text is to seek its origins. Examination of a text's origins often leads the historicist to the distracting possibility that there is an authorial intention we can retrieve, no matter how distant we are from the text's origins. In the historicist mindset everything we can say about a text is based on an assumption that the meaning of a text is exhaustively enclosed by the intention of its author, an intention excavated by a process that examines every nuance of the social-cultural conditions of the time of the text's original production. ${ }^{4}$ For the historicist, Biblical texts are to be read as sources, whosc origins define, control and limit any reference it has beyond its original context. Rather than reading the lext as it is, the historicist is distracted by an unholy triad: origins, intention, and context. The search for the text's origins drives the historicist towards re-constructing the author's intention, best recovered through fixed attention to the text's original context.

The drawbacks of such an approach are legion. From a non-theological perspective an uncritical atachment to history and origins can blind the scholar to the ideological and subjective forces at work in historical reconstruction. For H.G. Gadamer, historicism revealed itself in scholars who neglected their own historicity, and who thereby could not grasp that a truly historical understanding always involves our pre-tnderstanding of the history of effects of the text we are seeking to understand. Ironically, therefore, the naïveté of historicism is precisely a misunderstanding of the inevitably hislorically shaped form of our interprelations. 5

From the theological perspective of revelation to be defined below, historicism clouds the theological claim that the Christian life is energised, defined and sustained by that of which the text speaks, not the origins and original context of the text. What tultimalely mattcrs is not the putative situation behind the text, but the divine-human encounter that both drove the text's original composition and continues to sustain the text's interpretation. The historicist affords little space to the church as an interpretative community. In the perspective which equates meaning with origins,

\footnotetext{
${ }^{4}$ Ricoetr, 1976, 89-90.
} 
'Scripture is no longer understood as mutually constituted by the story it narrates and the community to whom it is narrated - a community already contained within the story, as the story within it. ${ }^{\prime 6}$

Histuricist Biblical scholars often work with erroneous models of authority. All authority is transferred to the (reconstucted) author's intention, a reconstruction that often enjoys the first and last word, and is deemed to be recoverable through attention to the text's uriginal context. This is an incipient form of epistemological foundationalism, an assumption that in a text's original context we have the absolute and tinsurpassable meaning of the text. For Karl Barth, the historicist mistakenly locates the revelation of the Biblical texts, the aspect of the text through which God communicates his will, in the events lying behind them.7 Such an approach mistakenly bifurcates the form and content of the text, for it is the very form of the text communicating its content that acts as God's revelation pointing beyont the text. In line with this, and as we will insist throughout this thesis, the ultimate authority within any theological understanding of Scripture is that to which its authors witness, not the context within which they articulated their witness.

At this slippery level of inquiry attention to metaphors and prepositions is important. True attention to the text, umbindered by distraction with the events behind the text, draws us closer to the text, and yet in drawing us closer to the text the text itself comes to disappear, as we scek meaning either within the text of Scripture, 8 or by looking towards that which the text directs our attention. ${ }^{9}$ In contrast to the historicist fascinated by the origins of the text, there is, in keeping

\footnotetext{
${ }^{5}$ Gadamer, $1975,299,314$.

${ }^{6}$ Loughilin, 1997, 47.

${ }^{7} \mathrm{CD} 1 / 2,492$.

' This image is important in Maximus the Confessor's interprctation of the transfiguration where Jesus' shining clothes become a symbol of illumination akin to spiritual reading of Scripture. See 'Difficulty 10 ', translated in Louth, 1996,96-154, 'The whitened garments conveyed a symbol of the words of Holy Scripture, which in this case became stining and clear and limpid to them, and wcre grasped by the mind without any riddling puzzle or symbolic shadow, revealing the meaning that lay bidden within them' (109).

${ }_{9}^{9}$ The inage of kooking away, towards the text's witness, was central to Barth's theolngy of reading Scripture. Paul is like the pointing hand of John the Baptist in Grünewald's painting of the crucifixion, signalling something far' greater than himself. See 'Biblical Qucstions, Insights, and Vistus' in Barth, $1957,51-96(65)$.
} 
together the form and ultimale content of Scripture the option to,

'leave the curious question of what is perhaps behind the texts, and to turn with all the more attentiveness, accuracy and love to the texts as such. ${ }^{\prime 10}$

\section{Revelation}

In referring to revelation we are, as before, employing a term that has been the focus of considerable debate. Revelation is unmistakably to do with the comununication of God's will to the world, but the mode through which we understand or conceptualise this communication is open to much interpretation. Some prefer a divine-speaking model, ${ }^{11}$ a verbal model in accordance with a conception of revelation as demanding more than human inference of God's will. Basil Mitchell gives voice to such a proposal of revelation as God 'speaking' to us, when he defines revelation as God communicating to his creatures fundamental truths about his nature and purposes which they otherwise could not discover.'12 Others, like David Brown, posit a developmental model of revelation, a mode of divine communication that continues through the life of the church. ${ }^{13}$ Still others, iike Maurice Wiles, posit a non-interventionist model of revelation, stressing receptivity and apprehension more than divine (verbal) conmunication.14 But Wiles' tendency to emphasise creation as revelation leaves him exposed to charges of deism.15 A Barthian understanding of revelation would articulate it as an 'event', puncluring linear time

\footnotetext{
10 CD $1 / 2,494$.

"As argued for by Abraham, 1982. Watson, F., 1994b, could also be understood within this perspective, though he indicates no awareness of Abraham's work. See Watson, F., 1994b, 388, 'if God is to reveal himself to us with the intention of establishing an interpersonal relationship, he must do so not only by making himself present to us it a manner somelow analogous to hutnan face-to-face cncounter, but also by verbal means, in the impartation of relevant information.' Watson's argument is compelling, though nltimately suffers frotn the suspicion that the model he constiucts rather too neatly fits into his theological exegesis of $A$ cts 9.

${ }^{12}$ Mitchell and Wilcs, 1980, 103-9 (103).

${ }^{13}$ Of the varions works of David Brown see, especially, Brown, D., 1994. This comes to doctrinal fullness in Brown, D., 1999; 2000. The previously eited article of Watson, F., 1994b, also moves in directions which are favourable to such a view of tradition, as he himself notes at $397 \mathrm{n}$. 10 . See Watson, T'., 1994b, 389, where he talks of 'new interpretations' of revelation being imparted in a process which 'remains constantly in motion'. Brown, D., 1985, 57-70, presents a critique of W.J. Abraham's 'divine-speech' model of revelation. In this satne volume Brown offers this programmatic definition of his understanding of revelation as "a process whereby God progressively unveils the trutt about himsclf and his purposes to a community of believers' (70).

${ }^{14}$ So Wiles in Mitchell and Wiles, 1980, 109-14.

is e.g. Mascall, 1977, 203.
} 
and proceeding from a point 'outside and above us'. ${ }^{16}$ As such il inferprets us; we do not interpret it. ${ }^{17}$ Revelation as a process, developed by Anglo-Catholics like David Brown, would arouse suspicion with Barthians who portray revelation as God's communication to the church's members, not as sonething generated internally from within the church's discourse,

'When revelation takes place, it never does so by means of our' insight and skill, but in the freedom of God to be free for us and to free us from ourselves'. I8

By positing the doctrine of revelation we have, indisputably, entered a realm of considerable complexity, a world containing a panoply of issues and unresolved debates. ${ }^{19}$ Since revelation is always the revelation of God, this only makes our language even more vertiginous. ${ }^{20}$ Despite the incvitable complexity of the issues, no theological project can afford to ignore discussion of how God reveals his will, the first and last question for failh.' ${ }^{\prime 2}$ In the exposition that follows we will turn to the work of a number of theologians, two of whose merit and usefulness to our project we set out in the thesis' introduction. Especially prominent will be the work and writings of a Reformed, an Anglican, and an Orthodox theologian: Kari Barth, David Brown, and Dumitru Staniluae. This eclecticism, typical of this thesis, is not meant to reduce the very important theological differences between these theologians, but to investigate how they can be convened in an attempt to understand the ultimate unity lying at the heart of Christian theology.

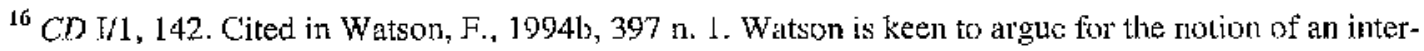
personal model of revelation as opposed to the 'event' model, the latter which he defines thus, 'als an event which can and does occur in the present, which engages the individual in an cncounter with ultimacy, which disrupts and disturbs what otherwise passes for normality, and which is resistant both to institutionalization [cf. David Brown] and to translation into communicable, propositional form' (Watson, F., 1994b, 384, emphasis original). Watson suggests three reasons to oppose the eventmodel: it suppressts the coguitive dimension of revelation; it fails to relate revelation to the linearity of our existence; and it cmphasises excessively the immediacy of the divine presence to humans (see Watson, F., 1994b, 396),

${ }^{17}$ Barth, 1936, 3-4.

${ }^{18} \mathrm{CD} \mathrm{I} / 2$, 65. See also Barth, 1954; 1937.

${ }^{19}$ For a treatment of somc of these issucs see Gunton, 1995; Swinburne, 1992; Astley, 1980; Mitchell and Wiles, 1980; Baillie, J. 1956.

${ }^{2 n}$ It wats this parndoxical situation that was noted by Barth, 'we ought to speak of God. We are human, however, and so cannot speak of God. We ought therefore to recognize both our obligation and our inability and by that very recognition give God the glory. This is our perplexity.' Sec 'The Word of Gnd and the 'Task of the Ministry' in Batth, 1957, 183-217 (186, emphasis originai).

${ }^{21}$ Ricoeur, 1981, 73 .
} 
When Christian theologians speak of revelation, it is the revelation revealed in Jesus Christ that they must prioritise. Keeping revelation and Jesus Christ together as synonyms reminds us that when we speak of revelation it must be God's revelation, or God's acts apprehended only by faith, of which we speak.22 The Christian revelation is, starkly put, God in Christ. This revelation is normative, because it is in this event that the Gospel is disclosed: that God met humanity in Jesus of Nazareth and, in the risen Jesus Christ, shows himself to be radically able to meet humanity still. ${ }^{23}$ The revelation that is God's manifestation in Jesus Christ is the defining event of Christian faith and history, and no Christian theology that wants to talk of God (let alone God's revelation) can afford to ignore this doctrinal concept.24 Our thesis is that although God's revelation in Christ is complete and unsurpassable, it is a fullness whose pressure is released into an 'infinite futurc'. ${ }^{2 s}$

Orthodox and Anglican theologians, like David Brown and Dtumitru Staniloae, conceive of revelation as a progressive process through time, a growth in apprehension and understanding in different times, sustained by the complete and constant revelation of God in Christ and the church enlivened by the Spirit. Robert Morgan's words would seem to indicate sympathy to such a model,

'By revelation is meant God's self-revelation, and since it is a metaphysical presupposition of those responsible for this modern use of the concept that God is wholly other from man and the world, this means that revelation can no longer be identified with a bit of world such as the biblical text or even the historical Jesus. It may be identified with 'Jesus Christ', by which is meant the Christ of faith. Jesus Christ is none other than the man from Nazareth, but he can only be apprehended as the revelation of

\footnotetext{
${ }^{22}$ On this point see, Astlcy, 1980, 340. See also Staniloac, 1994, 62, 'Faith is based on revelation, but revelation dues not lake place without faith.'

${ }^{23}$ For the final point see Williams, R., 1982.

${ }^{24}$ Our forcefully programmatic starements are not evasive of the metaphysical issues surrounding the incarnation's importance. From our perspective, the incarnation is important for what it reveals to humanity of the nature of God, and for establishing the means by which God warts to make himself known to humanity. To talk of the importance of an 'incarnational revelation' is to talk of a genuinely reciprocal relationship, where our conception of revelation is shaped exclusively by what is revealed in and through the incarnation, and our understanding of the incarnation's meaning and significance is properly shaped by a growing sense of how God reveals.

${ }^{25}$ Ralmer, 'The Death of Jesus and the Closure of Revelation', 135.
} 
God in the moment of faith. Thus while it is a past historical event which is actualised in successive acts of proclamation, the event of proclamation is here shifted from a clearly defined place in the past to a succession of moments in successive presents.' 26

Where we might diverge from Morgan is in our emphasis on the scope of this model of revelation. Our apprehension of revelation, founded in the person of Jesus Christ, has the capacity to expand ceasclessly, an expansion in line with God in Christ's infinite depth. And the more we understand, the more revelation both expands and evades our full perception. Revelation then is an infinite and ceaselessly progiessive movement experienced through the church, ${ }^{27}$ an intrinsically eschatological experience for it is 'a road leading towards the goal of our perfection in Christ.'28

Again, the primary commitment must be to the normative and foundalional event of revelation that is Jesus Christ. It is in the person of Christ that the absolute and unsurpassable 'dynamic' character of revelation has been grounded. ${ }^{29}$ All that Christ makes known is that his fullness is apprehended only 'in successive presents'. ${ }^{30}$ To say this, is to affirm that the revelation that is God in Christ can only be embraced in its complete richness insofar as it is understood that different elements of its revelatory potential will be revealed successively through time, rather than definitively in any one time. ${ }^{31}$ As the Lord of time, Christ will always spill out of our

\footnotetext{
24 Morgan, 1973a, 65.

${ }^{27}$ To re-emphasise, the sole revelation interpreted by the church is the complete fultiness of Gocl in Christ. The church is aided in this task of discerning amplificalion through the sustenance of the Holy Spirit, who comes so that we might know Cluist's benefits more exactly. The church, gathered by God in response to his Word, is then the locus of revelation, but is not in any way to be confused with what it both proclaims and lives in. It is possible to talk of revelation being experienred as an ongoing and deepening salvific reality without eliding the church with revelation itself, pace Bulgakov, 1937, 144 : 'Revelation continues in the Church for it is the Church'. There must be a sense, contrary to this perspective, that revclation is something that the church is continualiy absorbed by and within, without the church ever feeling that it governs revelation more than it is itself governed by it. Cf. CD NV/1,724.

${ }^{23}$ Stănilone, $1994,50$.

${ }^{29}$ Stăniloaé, 1994, 37.

${ }^{30}$ Morgan, 1973a, 65 .

${ }^{31}$ At this point it is necessary to indicate awareness of the implications of our argument. The wording of some of our argument could connote in the reader that we are hinting at some form of process theology, as pioneered by A.N. Whiteheat. For process theology, God's reality is, at least in some respects, 'describable in terms of temporal events, processes and inferactions' (Pailin, 1970, 303). Process theology emphasises that all entitics are in a state of process, and so insofar as God is an entity, he too must be in a state of process. The burden of our argument at this point of the thesis is not on process thcolugy's emphasis on the whole process of reality, but rather on revelation itself being grounded as a continuing reality by the event of the incarnation. One of the problems with proccss theology, as it is filtered through and interpreted by David Pailin, is that it would seem to currelate an
} 
attempts to confine apprehension of him in any one time.

Scripture, as a textual witness to the revelation of God in Christ, is an agency within this eschatological dynamic, for in every context of reading Scripture, as it interacts with an interpretative community that holds it as authoritative, revelation's profundity is more deeply explored. In every context led by the Spirit, Christ as the centre of revelation, 'seeks to be known and appropriated more and more deeply, and to be loved more and more intensely. ${ }^{\prime 32}$ The Biblical texts are themselves clearly the pioneers of this interpretative tradition, the fourfold diversity of the gospels a reminder, were reminder needed, of the diversity of interpretation which Jesus Christ, as the subject matier of the text, can bear. In this very important way, the text (insofar as it is read through Christocentric lenses) is constitutive and formative of the amplifying tradition with which it is partnet.

Deploying Clodovis Boff's metaphor, revelation is a 'spring of meaning' more than il is a 'cistern', 33 which is to say that Scripture is not some stagnant reservoir of meaning, whose historically controlled meaning is static and stultified in one time. Scripture, being a witness to revelation, witnesses to the nature of revelation in the way it endlessly conveys meaning and spiritual profundity through the time of the church. ${ }^{34}$ Gathering in meaning throughout its rich and varied course, Scripture points to a revelation eschatological in scope and direction. ${ }^{35}$ The revelation of Scripture, what God makes known throughout the cotirse of Scripture's

\footnotetext{
incarnational mode of knowing, with the knowledge attained by natural theology. Insofar as we accept that natural theology is "an attempt to deternine the being of God from evidence provided by natural processes' (Pailin, 1970, 312), our proposals catnot be allied with such a mode of knowing God. Where, for David Pailin, process theology is normative for how we perceive the incarnation, from our perspective, it is the incarnation that is normative for how we understand revelation. So, contra process theology: the natu'e of God's revelation then (in the past) is constitutive of the nature of God in the present.

${ }^{32}$ Stăniloae, 1994, 45

${ }^{33}$ Boff, $1991,19$.

${ }^{34}$ An appeal to the authority of the church as the interpretative comnunity of Seripture, the comnunity in which the Spirit is active, need not be confused with the authority of any hierarchy or Magisterium. Barth, not perbaps inmediately associated with alppeals to ecclesial authority, appealed to the authority of the interpretation of the whole people of Gnd, albeit an authority continually punctured and broken by the Word. See Bauth, 1991, 227-49; McCormack, 1991, 334-7. For a Roman Catholic presentation of the relationship between Scripture and the churcli's 'Tradjtion see Congar, 1966, 379-424. The Pope's interpretative authority receives robust criticism from Orthodox theologians like Bulgakov, 1937, 169-71.

35 The eschatological scope of revelation is a frequent theme in Gunton, 1995. Intriguingly Barth ton tatks of 'church history in the pregnant sense of the tcrm, that is, as the history of the church of God which may at times be hidclen but is never wholly missing.' (Barth, 1991, 239).
} 
interpretation, is that interpretation is directed towards a telos, for,

'If revelation, which has become fully real in Christ, possesses in itself a prophetic dynamism, a kind of prophecy in motion, the action of revelation to the time of its final goal is entailed in that prophetic dynamism which finds expression in and through the Church. ${ }^{36}$

This notion of revelation, with the principle of its end already in operation, is exceedingly pertinent to a Biblical text, like 1 Thessalonians, with its heavy eschatological tones. This notion of an cschatologically directed revelation, balancing out our place in time alongside the eschatological principle at work in the church, repudiates any notion of the church's understanding through time improving and perfecting itself sounding like a principle of idealism. Just as our understanding now is not down to our ingenuity, so full understanding will never come in the church's time of ever-growing amplification, but at the eschaton, which is proleptically at work in the church already. There is no sense of fulfillment within the time of the church. Rather this is what the church is continually advancing towards, for the life of the church is not in this time, as Sergius Bulgakov would assert, 'identical with itself.; 37 Keeping the end of revelation's time as an eschatological end, and not as an end in any way achievable by us, ensures revelation is free from being seen as merely a player in the results of historical processes. What revelation makes known is not that God has somehow been enclosed by history, but that the eschaton is itself driving history and lime. It is God in eternity who enters into time. It is not we, in lime, who decide how and when we enter into eternity. Working with a model of revelation defined by its telos, the church's amplification of revelation remains properly governed by its end in God.

The boundaries and norms of this dynamic model of revelation are ones shaped, defined, and justified by the ever-normative revelation: God in Christ. Keeping otw conversation fixed on the revelation energising all Christian discourse reminds us of the need to distinguish carefulty between the referent of our discourse, and the form of our discourse. The dynamic form of this model of revelation is essentially

${ }^{36}$ Stăniloac, 1994, 39. 
eschatological and dialectic. It is eschatological because it is understands itself as part of a movement directed towards a telos. Revelation also has a dialectical shape, for it operates by moving and growing in understanding around its constant axis and referent - Jesus Christ. This image of an expansion from the unifying centre and retum to Christ as central referent (whose perception is continually being transformed) naturally points us to our third concept ripe for definition 'conversation'.

\section{Conversation}

Neither interpreter nor text but the common subject matter takes over in genuine conversation.' 38

In a conversation around the normative revelation of Jesus Christ, as sketched above, there will be one pivotal aim, which will be to direct the interlocutors in their task, 'to let the revelation be heard, or let God be God.'39 This is best achieved through a faithful attentiveness to the subject matter of which Scripture speaks, which shapes and determines our conversation - Jesus Christ. From the theologian, David Tracy, we learn much about the potential of conversation as a hermeneutical exercise.40 To be sure, Tracy's model of conversation is developed independently from the concerns motivating our project, for Tracy has consistently attempted to relate Christian theology to pluralistic religious and cultural contexts. ${ }^{41}$ The charges provoked by Tracy's openly correlationist theology, ${ }^{42}$ based on notions of common human experience, need not detain us.

The model of conversation can only be accepted on the basis of two predicates. First, and here we start at the most elementary level, to converse, the interlocutors must be alive, and possess enough energy to be able to respond, question and provoke. There simply is no conversation when one of the interlocutors is dead or, less starkly, passive. Oux intexpretation of 1 Thessalonians will maintain the liveliness of the Word in the words by a two-pronged activity that will pay attention to the

\footnotetext{
${ }^{37}$ Bulgakov, 1935, 26.

38 Tracy, $1984 \mathrm{~b}, 124$.

${ }^{39}$ Morgan, $1973 a, 70$ ).

to His influences, however, are clearly Gadanter and Plato.

${ }^{41}$ For introductions and summaries of Tracy's work see Jeunrond, 1993; Sanks, 1993.

${ }^{22}$ So Tracy, 1989, 562-3. The opposition we are alkuding to, generated by such a project, is epitomised
} 
interprelations provoked by the text and contirues to open out the text's subject matter to new interpretation. Reading the text as witness, as something continually pointing away from itself and willing tas to understand the reality of which it speaks, keeps the text alive by allowing it to disclose the Word to us. This connects ts back, by contrast, to historicism, for where historicists ate distracted by what lies behind 1 Thessalonians, ${ }^{43}$ there is the promise that opening out in front of the text, "we recognise nothing less than the disclosture of a reality we cannot but name truth.' 44

But a text that has the capacity to be enlivened, rather than deadened some 2000 years after its original production, is no ordinary text. So where first we called for the necessity of a live text, the second predicate is part of the first, for only a classic can still provoke and question centuries after ils first appearance. A conversation is in need of a live text, and it is in need of a classic text, if the conversalion is going to produce any light. The problem which Tracy presents, and one where postliberal theologians like Lindbeck would charge him with failing in his duty as a Christian theologian, is that a 'classic' is more thought of as a literary than a Christian theological term. By importing such a correlationalist term Tracy is faced with the task of teasing out the difference represented by the Christian classic - Scripturc from the literary classics of Shakespeare, Milton or Keats. ${ }^{45}$ After all, if for Tracy a classic bears 'a certain permanence and excess of meaning that resists a definitive interpretation', 16 it is hard to see how the Bible holds more authority than a copy of King Leur. ${ }^{47}$

Nevertheless, the virtues of a conversational presence are exceedingly attractive. Werner Jeanrond aptly articulates Tracy's vision,

'The other must not be swallowed, but affirmed as other, if I really want to accept the possibility of becoming to some extcnl an-other,

\footnotetext{
in the postliberal manifesto of Lindbeck, 1984.

${ }^{13}$ For Tracy's similar concerns see 'Tracy, 1984b, 124.

44 Tracy: 1981, 108.

45 This is something to which Tracy pays attention in 1984a. In common with all other classics, a religious classic 'will provoke, vex, elicit a claim to serious attention'. But, a religious classic will also 'provoke some fundamental existential қuestion for the human spirit' (303).

$4 \overrightarrow{2}$ Tracy, 1984a, 296.

"Concerns equally expressed by Gunton, 1995, 72-3.
} 
that is, the possibility of learning and of changing, of transformation and conversation. ${ }^{\prime 4}$

At one level, conversation may just be the name we give to the necessary form of the interchange between the interpreter and the phenomenon to be interpreted. ${ }^{45}$ But a conversational hermeneutic has a lot more potential than this inauspicious description would indicate. A hemeneutical conversation, one committed to understanding and intexpreting, will be committed to listening to the claim of the other voice as truly other, for it is in the different contributions of the interlocutors to the same subject mattor that understanding is achieved. Correspondingly, a hermeneutical conversation is kept alive by the constancy and liveliness of the loing and fro-ing that pertains to any genuine dialogue.

As we will see in our examinalion of Krister Stendahl's proposals, and his own 'history of effects', a model of conversation realistically accommodates the necessarily two-way process between text and interpreter that is interpretation. Moreover, a conversational model of hermeneulics would seem well fitted to our understanding of revelation's dynamism. For a conversation has a predisposed reluctance to foreclose findings, possesses an enduring openness to new disclosures, and hence is compatible with our model of revelation as process, grounded in the revelation that is God in Jesus Christ. For at the centre of the conversation we are hoping to conduct with I Thessalonians lies Jesus Christ as what is common to the interests of both the text and the interpreter situated within the life and discourse of the church.

To converse with, in and through the text is something worked out in practice more than it is articulated and theorized. Consequently, the virtues of a conversation listening to all the interlocutors as other, without swallowing them up into an interpretative mélange will be something aspired to in practice - throughout this thesis.

These thrce terms - historicism, revelation, and conversation - are set out in

${ }^{48}$. Inintond, 1993, 158. 
exploratory fashion, as pexpectives which will both guide the course of the thesis and be worked out in greater detail through the various readings of 1 Thessalonians we undertake. Just as these terms display a certain preliminary quality in our understanding, so too is it important to pay attention to their mutual connections. Our model of revelation informs our anxictics in relation to historicist tendencies within Biblical studies. Likewise, the outworking of this model of revelation is only possible through the inlrinsically integrative vision at the center of Tracy's model of 'conversation', a feature exhibited in this thesis' eclecticism and inter-disciplinarity (incorporating Biblical studies, historical theology and systematic theology).

49 Tracy, 1987, 10. 


\section{(2) Case study and critique of the work of two historical critics}

Having set out preliminary explanations of some guiding concepts, we can turn our attention to specific historical-critical work. Our case studics of the work of two historical critics shall begin with an examination and critique of a classic defence of the past as past, by J.1.G. Dumn.50 Moving on from this more general overview, we shall turn specifically to historical-critical work on 1 Thessalonians, examining K.P. Donfried's work on the theology of the Thessalonian correspondence. ${ }^{51}$

It seems apt to begin this critique of the work of specific historical critics with James Dunn's essay, in which he programmatically sets out the propriety and necessity of historical-critical work. As a scholar who has dedicated his academic career to meticulous and historically rigorous work, it is no surprise that Dunn seeks to establish the case for historical-criticism. Our critique of his argument will provide a helpful introduction to the nore sharply focused critiques we will present of specific historical-critical work on 1 Thessalonians (\$ 3).

In his 1995 essay, "The Historical Text as Historical lext: Some Basic Hermeneutical Reflections', Duun essentially has two arguments that, in isolation, no reasonable scholar could disagree with. First, Dund argues for the necessity of 'Lower Criticism', the work concerned with the actual Greek of the New Testament requiring exegesis. In his argument that, as a historical text, the church (and presumably the academy) 'will always need to be able to call on members or specialists who are familiar with the Greek text' nobody could disagree. 52 One need only read any exegetical exctursts of Barth's Church Dogmatics to realise how serious systematic theologians have long been convinced of that part of Durn's argument. It is indisputable that some degree of linguistic competence is important to the understanding of the New Testament.

Durn's second argument is for the 'Higher Criticism', charged with the aim of 'reconstructing the historical circumstances out of which the New Testament writings emerged', for 'the meaning of a historical text is dependent in some degree

\footnotetext{
${ }^{50}$ Dunn, 1995.

${ }^{51}$ Donfried, 1993.

${ }^{52}$ Dunn, 1995, 343.
} 
on its historical context. ${ }^{54}$ Durn is right to argue that, "The historical lext is linked to its historical contexl as a plant is rooted in the soil which first nourished it', but runs up against a whole host of hermeneutical questions and issues when he insists thal, to attempt to transplant that plant by ripping it clear from its native soil and shaking it free from that soil may work, but it is likely to kill the plant.'sis The logical jump that Durn makes here leaves him vulnerable to hermeneutically driven critiques. It is certainly true that in a very important sense one meaning of the Biblical text is that which is germane to its historical context. It is at the point that Dunn jumps from the assertion that there is a historical meaning (which there undoubtedly is) to the assertion that the NT (sic) is nothing if it is not first and formost a series of documents written in the Greek of the first-century Mediterranean world' that we diverge from Dunn. ${ }^{55}$ What has been canonized, after all, is not the authorial intention or the text's original context, but the text itself as a witness to revelation.

The hermeneutical questions provoked by Dunn's arguments proliferate. In what sense do historical origins really provide the 'firm rule and norm' for the meaning we find in the text now?50 Why does Dunn appeax to limit the 'truth' of the New Testament text to its historical referentiality?57 In Dunn's positivist hope that we must 'transplant' the soil and plant logelther (i.e. original context and text) into our context now, is it not possible to detect an inappropriate prioritising of Christian origins, a move that risks limiting and foreclusing God's continting revelation?58

In a Barthian mode, the truth of the text inheres in the subject matier of the text itselE, not the atsthorial intention or situation behind the text. This observation reminds us that much historical-critical work often operates with an unspoken theolugy.59 James Dunn stands in a long line of Biblical intexpreters who, through

\footnotetext{
${ }^{53}$ Dunn, 1995, 344.

54 Dunn, 1995, 344.

${ }^{55}$ Dunn, 1995, 346 (emphasis added).

${ }^{56}$ Dumn, 1995, 347.

${ }^{57}$ Dunn, 1995, 346, says of historical-critical interpretation, 'the goal in all these cases has been to be 'true' to these texts, and that 'trutl' can never be separated from their character as historical texts.'

58 This is something about which Dum is candid. Without its established historical meaning "the lext is ever in danger of functioning merely as a puppet or a plaything.' (Dutn, 1995, 347).

59 So Morgan, 1973a, 89, 'The reason why supposed, neutral, objective, dispassionate, debate about historical questions relating to the New Testament is often so passinnate and polemical is that theological positions are bcing defended with the weapons of historical argementation.'
} 
their historical work, explicitly or implicitly, advocate a theology that situates doctrinal purity uncritically close to historical inquiry. ${ }^{60} \mathrm{It}$ is where this theology is unspoken that a hermeneutics of suspicion is required, ${ }^{61}$ for a conversation's integrity is marked by the honesty of its interlocutors.62 One of the things which a theological inlerpreter of the Bible is interested in, is transcending its original context in the hope of engaging with the elernal subject matter of the text, namely the true 'relevancy' and authority within the text. Dunn's inperative may be to keep lext and original context together, bul our imperative is to keep text and the subject matter of the text bound together, for if we are to be charged with the prioritising of anything we hope that it is with the subject matter of the text, that to which the text witnesses. One of the things we know through the text is that the subject matter of the text has the capacity nol just to engage with a host of different contexts, but also

${ }^{60}$ Yeago, 1997, 95-6.
${ }^{61}$ Helpfully, Dunn has set out his theology of the Bible's role in the clurch in Dunn, 1996. Here Dunn classifies the role of the Bible within the church under the headings: information, definition and inspiration. On the one hand Dunn asserts that it is important to know about "the period of birth and carly childhood' of Christianity if the church is to 'properly know itself'. But, on the other hand, Dunn then asserts that what we learn through the Biblical narrative is 'the ways and means by which Gool was cneoutitered or experienced by people living fully within the flow and eddies of the moving strcan of history' (119). From our perspective it is this latter claim which is normative, for what the Bible (and here we especially mean the New Testament) is foundational of is the declaration that God has committed himself to a process of discovery within the contingencies of our interaction with him. It is in this way that the interpretative community that is the church, stands in line with the subject matter wittin 1 Thessalonians. We find ourselves disagreeing with Dunn's theology for precisely this reason: where Dunn restricts God's revelation 'within the contexts, contingencies and relativities of historical situations, events and processes' within the curly church, we are more concerned that it is precisely in the texts that it is disclosed that God has established his self identity (via the incarnation) within 'the moving stream of history', and thus the continuing process of revelation is to be focated somewhere beyond the original context of production of the text. Contra Dunn, the revelatory capacity lies not in the early church, unmasked by positivist historical endeavour, but in the process of revelation intiated by God in Christ. Dunn's theology would appear to limit God's revelation to residing wholly within the Bible, whereas from our perspective it is through the words of the Bible we can sce how the Word can continue to be revealed in the conversations the Bible provokes. Where Dunn rightly stresses that historical work is an inevitablo consequence of a story in which God in his self-revelation in and through the man Christ Jesus puts himself at the mercy of history' (120), and yet limits that process to Biblical events, we are struck by the image of Dunn seeking to foreciose and define the boundaries of God's revelation, whereas what is established in the incarnational model of revelation is the kind of understanding that will elide readers exclusively concerned with the text's context of production.

Later on in this paper, Dumn reveals morc of his theology when he states, 'Recent years have seen an increasing recognition that within the twofold norm of scripture and tradition primacy must be given to scripture, that the canon must be allowcd to function as norm within the twofold norm, that scripture must be recognised to have a criticul function vis-à-vis tradition.' Whilst we certainly have no problem with Scyipture being allowed an authority within the church (!), the problcm is what is nucant by 'scripture'. II, by 'scripture' having authority within the church we do not menn the eternal subject matter of the text as the text itself reveals is to be further disclosed in contexts independent of the context of the text's production, but, as Dumn slips out a few lines down "the histurical language, itiom and struclure of the biblical witness retain[ing] a definitional authority' (126) then we cannot agree with such a theology. See further Dum, 1995, 346-7.

${ }^{62}$ See 'Thenlogical Intcgrity' in Williums, R., 2000a, I-15, 'Discourse that conceals is discourse that 
to point us to meanings distinct from any reconstructed intention of Paul. In the face of Dunn's olsservations we have, therefore, two central criticisms to make.

1. Those interested in the 'Tistory of effects' would remind Dunn of the rich meanings which the Biblical text can bear in different communities, at different times over the centuries. Such a stance, which takes into account the range of meanings the text bears over time, shows a greater fidelity to the 'historical text as historical text'. The opinion of David Steinmetz that, 'The meaning of historical texts cannot be scparated from the complex problem of their reception and the notion that a text means only what its author intends to mean is historically naive' is one worth recalling in this perspective.63 Such meanings remind us that the "infinite content' of the text's reference is much richer than its original meaning in ils context of production, ${ }^{64}$ radically qucstioning and destabilising the normative role 'authorial intention' has long enjoyed.

It is timcly to clarify our thoughts here on 'atxthorial intention'. Contrary to those hislorical critics like Dunn, who presume that the author's intention is nol just retrievable, but essential for understanding the text in question, we have two problens with the quest for the author's intention. First of all, we suspect that an author's intention is irretrievable. This stands for any text. Second, and here we are arguing with Scripture in mind, even if we could ever retrieve an author's intention this could only ever act as a misplaced source of authority.

In relation to the first problem, it seems almost beyond question that what an a1thor intended when he wrote a text is inherently irretrievable. Whilst we can certainly accrue information about the writer's context, his circumstances of writing, and the likely situations he wanted to address, there is no way we can hope to enter into his or her 'intentions' in writing. Once we start questioning the quest for an authur's intentions the questions proliferate. What do we mean by 'intentions'? Do we mean understanding the mental processes in the author's mind as he wrote, the surely fulile attempt to 'tune into ghostly impulses withitn ...[the writer's] skull.'?55 Similarly, how do we account for those parts of the text that could not be part of the

(consciously or not) sets out to foreclose the possibility of a genuine response' (3).

${ }^{63}$ Steinmetz, 1980, 37 (emphasis indded).

${ }^{67}$ Stăniloae, 1994, 82. 
author's 'intention', the use of phrases and images over which the author had no control? What room are we willing to give to the author's lack of control of the text?66 Equally, how do we account for those 'intentions' that the author simply failed to communicate, assuming that there is no such thing as a perfect congruence between articulation and 'intentions'.67 In this sense much talk of 'authorial intention' treats too dismissively the inevitably complex relationship between 'intention' and the words of a given text.65 To move from knowledge of an author's context to a suggested 'intention' in writing is highly tempting, but ultimately it must remain a chimera.

Second, even if we could retrieve the author's intention, it is highly questionable just how useful or desirable such an 'intention' would be in understanding Scripture. All texis are, to a certain measure, released by their authors. In the context of Paul's letters, these texts become part of a very specific 'social treasury', ${ }^{6}$ namely the discourse of the interpreling church, whose task it is continually to unfold revelation's meaning. This should not be seen as some subversive 'dethroning' of Paul as author, but a corrective against those who deploy Paul as a 'passive exegete', 70 a tactic that confuses the meaning of the text within its interpretative community (the church) with a verifiable authorial intention. Understanding 1 Thessalonians is about more than understanding Paul as author, an author whose intentions are presumed to hold the authoritative key to the meaning of the text.71 Our role is not to police the meaning of Scripture by appealing to a probable authorial intention, but to recognise that the meaning of Scripture is historically generated within the life of the interpreting church, and it is only from within this interpretative community that authority is most properly exercised.72

\footnotetext{
${ }^{65}$ Eagleton, 1996, 99.

${ }^{66}$ A major theme in $\mathrm{Eco}, 1992$, 'Between the unattainable intention of the author and the arguable intention of the reader there is the transparent intention of the text' (78).

67 Thase two gluestions therefore ask us to consider the possibility that there may be intentions of the cext independent of the author, and that there may be intentions of the author independent of the text. Neither of these possibilities is considered with enough depth in the drive for 'authorial intentior'.

${ }^{68}$ Fagleton, 1996, 58-60.

${ }^{6} \mathrm{Eco}_{1}$ 1992, 67.

${ }^{70}$ Burke, 1998, 23.

$7 \mathrm{cf}$ Barthes, 1977.

${ }^{72}$ Watson, $F$, 1997, 95-106, defends the importance of the authorial intention. There are a number of problems with Watson's suggestions. First, there is a hage and unfortunate characterisation of plurality in meaning as 'laissez-faire interpretative pluralism' (97). Insofar as Scripture's profundity is amplified from within the community of the church, the proper constraints and limits will alwalys be there for members (or hierarchies) to declare what is and is not faithful to the whole faith of the church.
} 
2. The timeless aspect in any Biblical text is its revelation, what God makes known through the text. It is this aspect of the text that is authoritalive for it is this, rather than any irretrievable atuthorial intention, that has sustained its life in the church. The text's authority is thus sustained by its participatory quality - its constancy in encouraging people to engage with the transformation it points towards. ${ }^{\text {s }}$ Coming to terms with the subject matter of the text, that revelatory aspect which points beyond to the text's boundless potential to unravel in meaning, the role of the text is properly understood,

'It is rather a question of our being gripped by the subjectmatter...really gripped, so that it is only as those who are mastered by the subject-matter, who are subdued by it, that we can investigate the humanity of the word by which it is told us. ${ }^{\prime 74}$

Properly subducd by the subject matter of the text, comprehending its potenlial to change our historicity we will therefore stand in congruence with the 'intention' of Paul (or any other Biblical author). One of our presuppositions is that Paul's intention was not to be bedazzled by his context of production, but to artictulate how God's revelation in Christ has dramatically changed that context, and presumably every context. Reading the text as a sign and pointer to this revelation, our presuppositions are somewhere in line with the apostle Paul's - to communicate 'the Word of God which is at work within you' (2:13).

Dumn's essay represents a misplaced enthusiasm for the past, as if it was in itself atuthoritative, and an outmoded presumption that the past (the 'soil' of the text's context of production) can be cleanly 'transplanted' into our time. Grammatical and lexical reading of the New Testament is patently defensible, and ingredient to

Plurality, and richness of meaning does not, at least not in the discerning will of the church, mean that 'anything goes'. In the face of Watson's fear of countless, subjective readings, 'it needs to be said that most readings are offered within traditions, communitiks, and institutions that set limits to intcrests and purposes an interpretation may serve.' (Stout, 1982, 8). Sccond, white we have sympathy for Watson's assertion that the meaning of a text is bound (in some way) to the text we simply have no confidence that we can move from text to the author's always-putative intentions as easily as Watson supposes. Third, Watson gives no space to the consideration of the mysterious affirmation that God is somehow the Author of Scripture, an assertion which in the apprehension of its nystcry might have made Watson less suspicious of multivocity.

${ }^{73}$ of. Green, J.B., 2001, 323.

${ }^{74} \mathrm{CD} \mathrm{I} / 2,470$. 
responsible readings of the text. ${ }^{75}$ But when historical critics start alluding to entering into the spirit of an age and atthor, and claiming a hermeneutical priority and authority for these reconstructions, then the ground onto which they have stumbled becomes immediately more treacherous.

This examination of Dunn's work clarifies our concerns about historical-criticism. What is 'first and foremost' for us is the subject malter discemed by close attentiveness to the text, and not the historical context of the text, for it is the text, as witness and pointer to revelation, which has through history always pointed beyond itself, to encourage readers to grapple with what it is really saying. To connect with the reality of what Patl was transfixed by, is not to connect with the text's 'historical othemess' 76 as if it was this that fascinaled Paul. What Paul is absorbed by is the revelation of Gud revealing his will for us. Dunn would no doubt claim that he is defending the integrity of the text. Ironically, however what he is actually doing is defending the predilections of historical critics, and neglecting Scripture's own claim to be a witness to God's revelation.

Karl Donfried's contribution to The Theology of the Shorter Pauline Letters on the theology of 1 Thessalonians is not so much a dynamic work of interprelation, as an example of historical theology. Barth's criticism of historical-criticism could just as well apply to Donfried's work. Far from grappling with the subject matter of the text until the walls of the twentieth century and the first century become 'transparent', 77 possible only through a genuine engagement with the text's subject matter, Donfried works with the text at a level which stultifies the text's dynamism.78

Donfried's analysis of the theology of 1 Thessalonians moves from establishing the

\footnotetext{
${ }^{75}$ Since, when it comes to our exegcsis of 1 Thessalonians, we will be paying attention to the original Greek, it would seem propitious to set out some hermeneutical parameters for this 'lower eriticisin'. Eco, 1992, 68, points out that 'a sensitive and respotsible render' is aware of, and takes into account, the state of language at a text's time of writing. When tianslating the phrase 'sous of light' in 1 Thessalonians 5:5 it is, for example, important to know that 'pwrós' should be translated as 'of light' and not anything else like 'of God'. Careful rendering of Paul's words is a useful reminder that language is not sometling with which we ate free to do whatever we like. 'l'here is, however, a very real difference between this basic responsibility towards language and the presumption to know what was in Paul's bead as he used certain words.

76 Dunn, $1995,358$.

${ }^{n}$ Barth, 1933a, 7 (referring to Calvin's exegesis in the preface to the $2^{\text {nit }}$ edition of Der Romerbrien).

${ }^{78}$ So Torrance, 1990, 118, on Bartin's model of interpretation, "True interpretation takes place, therefore, where perception of the meaning of the biblical text and understanding of the reality it
} 
setting of the correspondence, to expositing the theology itself, setting out the relationship between 1 Thessalonians and Acts, and then suggesting some ways in which 1 Thessalonians may hold some contemporary relevance. In other words, he moves in a way Dunn would approve. Assuming the text is a product of its context, what it says is judged in the light of its reconstructed context of production (and not in light of its subject matter), and from this perspective Donfried moves to 'transplant' this reconstruction into our contemporary context to see what this reconstruction might say. Donfried's candid opening assertion itself indicates this move, 'It is a major contention of this analysis that an awareness of the social situation in Thessalonica... will greatly assist the task of understanding the theology of 1 Thessalonians. ${ }^{79}$ For Donfried what 'will greatly assist' in understanding 1 Thessalonians in reality always sidelines the text's tichness of meaning in contexts other than its origins.

It will be one of our criticisms below that historical critics tend to slip into a simplistic correspondence between text and context, seeing the text too often as a strbsidiary or servant of its context. Historical-criticism has the capacity to deaden the power of langtage, seeing it merely as a pale reflection of its original contexl, rather than something with the potenlial to transform both its original context and all subsequent contexts. In Donfried's purported theological study of a Pauline text, there is little engagement with the text as a revelatory text. It is our contention that if we really want to understand the theology of 1 Thessalonians we must commit ourselves to a conversation around the subject matter which unites both us as readers and the Thessalonians, a stbject matter which historical critics will be illdisposed to perceiving insofar as, by its eternily, it transcends any one partictular moment of history. The meaning of what is said in 1 Thessalonians is neither captured nor exhausted in first century Thessalonica. For the historicist temptation that Donfried cannot resist is that the meaning of the text is its historically recovered meaning, which is certainly one meaning, but not the meaning of the text. By seeking, behind the ever present historicity of the New Teslament, for an engagement with what Barth calls 'the message itself', namely 'a unique evenl, a truly singular occurrence, with a significance far beyond anything the New 'lestament writers themselves or their contemporaries ever dreamed of', then we

indicales are one.' 
will have the chance to do more than just write historical theology ${ }^{80}$

Donfried assumes that to understand the theology of 1 Thessalonians is to reconstruct (as far as is possible) the reasons why Paul wrote what he did.s1 Thus Donfried argues that the Thessalonian Christians are undergoing severe persecution, even to the point of death, ${ }^{\text {iz }}$ and suggests that, 'Paul's intention in writing 1 Thessalonians is to console a Christian community suffering the effects of persecution and death, to encourage the discouraged.'83 Throughout his exposition of the theology of 1 Thessalonians, Donfried understands the theology purely in functional lerms, 'the references to the suffering of the Lord himself, of Paul, and of other Christian congregations serve as a fundamental encouragement for the Thessalonian Christians, who find themselves in a difficult situation. ' 34 Whilst this passes as an acceptable historical understanding of the text, it can constiltte only the very beginnings of a suitably gripped exploration of the text's theological meaning.

Our argument is therefore this: that Donfried (and many other colleagues) think that once you have got at the history behind the lelter, you have got at the theology in explaining its function. Get the history right, and you will get the theology right, or so the historical-critical argument would seem to be. We remain suspicious of such a simple correspondence between history and theology. Rather, we would argue that it is vital to read the text in the complete richness of its historicity, striving to go beyond and reach out 'far beyond ourselves', 65 to grasp the same subject matter that drove Paul to undertake his missionary journeys. To undertake this task may well prove to be in complete fidelity to Paul himself, for Paul too was driven to seek that which was always above and beyond him, he too was totally absorbed by something (Someone!) other than himself: 86

\footnotetext{
${ }^{79}$ Donfricd, 1993, 3 (emphasis added).

${ }^{30}$ Barth, 1962, 85 .

${ }^{B 1}$ Such a yiew is classically expressed by Jowett, 1861,378 , 'Scripture has one meaning - the meaning which it had in the mind of the Pruphet or Evangelist who first uttered or wrote, to the hearers or readers who first received it.'

${ }^{82}$ Donfried, 1993, 22-3.

${ }^{83}$ Donfried, 1993,5 .

${ }^{84}$ Donfried, 1993, 44 (emphasis added).

${ }^{* 5}$ See 'The Strange New World Within the Bible" in Barth, 1957, 28-50 (33). So too Barth, 1933a, 19, 'we must learn to see beyond Paul. This can only be donc, however, if with utter loyalty and with a despcrate earnestness, we endeavour to penetrate his meaning' ( $3^{\text {rd }}$ preface to the 2 nd edition of Der Römertrief).

${ }^{86}$ McCormack, 1991, 326.
} 
Since the history which Donfried wants to re-construct is largely inaccessible, and there can be no possible chance of re-creating the experiential circumstances of 1 Thessalonians, if we do want to get at the theology of 1 Thessalonians it may be wise not to invest everylhing in the historical project. The only thing that the text makes as accessible now, as then, is the subject matter to which Paul, as apostle, witnesses.

Donfried's work falls short of what we would term a 'theology of 1 Thessalonians' not because of his historical-critical approach (which stands to show his considerable learning), ${ }^{87}$ but simply because the text's historical origins is Donfried's only conversation partner. There is no engagement with the history of effects, or with the stbject matter of the text. In this sense there is no attempt to confront the subject matter that generates the text's revelatory potential through time. Since we have consistently argued that the theology of 1 Thessalonians is only accessible via a multi-layered conversation it should be clear where the points of divergence with our project will lie.

The poverty of Donfried's project becomes all the more clear when we move to a consideration of his final chapter, where he evaluates the contemporary relevance of the theology he has just outlined. For Doniried, the theology of the Thessalonian correspondence is of 'remarkable relevance' for the contemporary church. ${ }^{58}$ Donfried locates this relevance in the fact that whereas the Thessalonian church was 'surrounded by pagan religions and a threatening political environment', so too, in the modern church, is there a need to reckon with a climate in which, not only is it in 'a minority position', but is surrounded by 'atheistic idcologies and deconstructed versions of 'Chrislianity".'89 Whilst we are sympathetic to the analogical relationship Donfried is trying to construct here, 90 we are not convinced that Donfried's project possesses sufficient hermeneutical sophistication to construct and sustain such a proposal. It is not so clear that one can ward off the past from present conceptions (for that is the project of historical-criticism), and then imunediately cast that into the present as an authorily. To project the past into the present as an.

\footnotetext{
${ }^{87}$ A good example of the necessarily philological character of the historical-critical approach is Donfried's atgument for the understanding of the much debated word, rxevias; in 1 Thessalonians 4:4. Donfried, 1993, 49-50, locates the meaning of the word in the context of the Dionysiac mystery cults.

s8 Donfiried, 1993,73.

sonfried, 1993,73.

${ }^{90}$ A hermeneutical proposal lavoured by, amongst others, Ricoeur, 1989, 286.
} 
authority, there needs to be an appropriate means of getting between the two, and an agreement of what precisely is authoritative. In short, Donfried may know where he wants to go, 91 but he may not know how to get there,

'Approaches which start from a neutral ground never can do full. justice to the theological substance because there is no way to build a bridge from the neutral, descriptive content to the theological reality. It is simply a presumption of historicism to assume that tools which function adequately in one area can claim the right of priority in the theological task as well. ${ }^{92}$

It is not immediately clear that the necessarily conlingent and unstable meanings of the past can nutomatically play a normative role within the life of the church without some kind of hermeneutical framework. Accepting the text as authoritative only works within a framework which allows for a conversation between the past and present, respecting the two as different spheres, and yet convinced that the two can be brought to a point of unity insofar as they converse around the subject matter of the text, a subject matter which rulcs and determines the interpretation. Viewed from this perspective, Donfried's highlighting of Paul's understanding of faith as a dynamic event,93 or the abiding validity of the sexual ethics, ${ }^{94}$ are valuable conversation pieces, purely as examples of historical theology. Our point is that much more work, lime and patience is required to justify the claim that stach (historically mined) information is of 'remarkable relevance for the contemporary church' 95

Our consideration of Donfried's theological project has outlined some of the reservalions that we have in the face of the claims he makes. It must be re-stressed that our criticism is not of the work of historical-criticism per se, but rather of the claims its practitioners make for it. Donfried's work may be historically illuminating, but theologically it shows how much more work there is to be done.

\footnotetext{
${ }^{21}$ So Donfried's elegant statement of ecclesiology as Donfried, 1993, 79, 'the call to God's kingdom is the call to the church universal, catholic and ecumenical, to be the sacrament of hope for the world's future'.

${ }^{92}$ Childs, 1964, 438.

${ }^{93}$ Donfried, 1993,74

${ }^{94}$ Donfried, 1993, 76 .
} 


\section{(3) Three critiques of the historical-critical project}

Our examination of the work of two respected historical-critical scholars has encouraged us to engage with historical-criticism as it actually operates within the guitd of Biblical studies. Our continuing engagement with historical-criticism moves us along the way to launch three criticisms of the historical-critical project.

Firstly, historical-critical studies operate with a limited notion of meaning and truth.

Secondly, historical-criticism is disalled by a historicism that fixes the language into a restrictively reflective relationship between text and original context.

Thirdly, the latent historicism within historical-criticism distracts historical critics from the actual subject matter of the Biblical texts.

\subsection{Meaning and truth}

Our first critique is that historical-criticism works with a restricted notion of truth and meaning, proritising the original meaning of the text to the neglect of the wealth of meaning generated by Scripture's life in the interpretalive community of the church. We wrill explore this critique by initially focusing on a general example of Biblical scholarship, after which we will examine work directly pertaining to 1 Thessalonians.

The exemplar of descriptive New Testament study - distinguished by its attempts to bifurcate the meaning of the Bible into a meaning 'then' and meaning 'now' - is Krister Stendahl, lately of Harvard Divinity School. Stendahl himself should properly be located within a broad trajectory stretching back to J.P. Gabler in the cighteenth century, $9 \mathrm{~W}$. Wrede in the nineteenth century, ${ }^{97}$ and one continuing to find expression in scholars such as Heikki Räisänen. ${ }^{98}$

The root of Stendahl's influence lies in his 1962 article in the Interpreter's Dictionary

\footnotetext{
${ }^{25}$ Donfried, $1993,73$.

"5 See Sandys-Wunsch and Eldredgc, 1980.

${ }^{97}$ See Ollenburger, 1985, 39-42; Morgan, $1973 \mathrm{~b}$.

${ }^{98}$ Räisänen, 2000; 1998; 1992; 1990.
} 
of the Bible entitled 'Biblical 'Theology, Contemporary', in which he pressed for the distinction between descriptive theology and normative theology. For Stendahl these are two distinct labours. It is the job of the Biblical scholar to establish 'what the text meant', and the job of the systematic theologian to move towards an explanation of 'what the text means'. StendahI credits the religionsgeschichtliche Schule with pushing for a distinction between what the text means and what the text meant, a distinction easier to appreciate when you are as acquainted with the religious and cultural diversity of first century Mediterranean life as the proponents of the religionsgeschichtliche Schule attempted to be. The religionsgeschichtliche Schule is applauded for fostering an attitude that saw the experience of the distance and strangeness of biblical thought as a creative asset, rather than as a destructive and burdensome liabitity.'99 The religionsgeschichtliche Schule lead to two different responses, what Stendahl terms 'liberal' and 'orthodox' stances. The liberal interpreters of the nineteenth century allowed their predilections of what was of continuing meaning to feed into their historical reconstructions, such that the two realms of past and present meanings became suspiciously correlated, and the reconstructed words 'happened to square well with the ideals of the modern age'.100 Likewise the orthodox interpreters were also poor historians, systematizing the Bible and thereby silencing more awkward texts. 101

Stendahl proceeds to examine the work of three scholars who were acutely aware of the chronological time difference between the time of the text's production and now: Barth, Bultmann and Cullmann. Not surprisingly, Barth fails to impress, promising in his Der Römerbrief a commentary but delivering what 'tums out to be a theological tractate'.102. Bultmann is out of favour for his primary interest is in establishing what texts can say of kerygmatic and existential significance, an interest that clearly militates against the import of establishing what the text merant.103 Cullmann, finally, is recognised as 'the most productive contemporary writer in the field of NT theology ${ }^{\prime}, 104$ but nevertheless he too lacks the hermeneutical agility to

\footnotetext{
${ }^{19}$ Stendali, 2000b, 72-3. Stendahl's article hias been recently reprinted in an SBL volume entitled, Reading the Bible in the Global Village. The 1962 article will hitherto be referred to by 'Stendahi, 2000 b'.

${ }^{1 \text { inn }}$ Stendall, 2000b, 71.

101 Stendahl, 2000b, 71.

${ }^{102}$ Stendahl, $20006,74$.

${ }^{103}$ Stendahl, 20006, 75-6.

${ }^{104}$ Stendahl, $2000 b, 76$.
} 
translate his findings into contemporary meaning and relevance, so unwittingly allows the descriptive method to 'transcend its own limitations'. 105 For Stendahl, the work of these three scholars reveals that the relationship between what the text means and what it meant is primarily 'competitive' in nature, 106 with now one side losing out, then the next. Stendahl's clarity as to the distinct natures of the descriptive and the normative tasks of theology is designed to eliminate any such confusions.

In subsequent articles Stendahl has elaborated on this two stage hermeneutical process. In a paper presented to the SBL in 1964, and published in 1965, Stendaht attempts to divest Biblical theology's historical descriptive task of any authority, allotting authority to the work of normative thinkess who establish 'what it means'. The descriplive role of Biblical scholars must be applied without distinction, 'This limitation of descriptive biblical theology must be imposed rigorously. We remember that everything called "biblical" easily becomes adorned by the authority of the Scriptures.'107 The Biblical scholar is thus the historian in the midst of theologians, describing the thoughts of the first, early Christian theologians whilst keeping a safe distance from the normative tasks of systematic theologians. The overriding objective is the urgent attempt to rescue the church from the arrogant imperialism of biblical theology', and so to hamess the 'freedom and creativity of systematic theology ${ }^{\prime}{ }^{108}$ Stendahl's atomising tendencies do not end there, for although he adopts the language of 'dialogue', ${ }^{109}$ in reality he wants to close off Biblical studies 'from the heavy layers of interpretations accumulated over the centuries ${ }^{\prime}$ in pursuit of the original meaning. 110

A number of criticisms have been ranged against Stchdahl,111 some more theological

\footnotetext{
105 Stendals], 2000b, 78.

106 Stendahl, 2000b, 78 .

107 Stendahl, 1965, 203.

${ }^{108}$ Stendahl, 1965, 204. Stendaht shows a remarkable consistency on this point. In a collection of essays published in 2000 . Stendahl holds that his attempt to get at the original meaning of texts, and thereby dethrone Biblical theology entitles him to be a member of a "deparlment of public health" within the theological enterprise: (Stendahl, 2000a, 63).

109 Stendah1, 1965, 208.

${ }^{10}$ Stendahl, 1965, 207.

"11 c.g. Watson, F., 1994a, 33, "T'o appeal for" an autonomous "description" is to ignore the fact that there is no such thing as a pure description of a neutral object; description always presupposes a prior construction of the object in terms of a given interpretative paradigm."
} 
than others.112 At this preliminary stage it is apt to echo James Barr and express concern aboul the use of the words 'means' and 'meant'. It is very clear that establishing what the text 'meant' is largely determined by the questions we set to it - rhetorical, sociological, theological, historical. In short, it is not clear that there is any one 'meaning' of the text that can be articulated univocally and used, in Stendahl's metaphor, as a 'baseline' for subsequent interpretations., ${ }^{113}$

If what the text 'meant' is a polysemous field, then so too is the field of the text's meaning now crowded with possibilities. Apart from the consideration that it is obvious that the church holds no monopoly over the contemporary meaning of the texts, the church itself witnesses (wittingly or tunwiltingly) to a pluriform interpretative tradition. To say this is a variant upon the adage that church history is the history of the interpretation of Scripture. For literary theorists, quite apart from theologians who stress the excess of meaning pertaining uniqucly to the Scriptures, it is evident that 'any text can be described truly in potentially infinite ways'.114 And besides the rich potential of what the text is to 'mean' now there is the subsidiary but no less important consideration, that we construct contemporary meaning from previous forms of meaning, and so too conceptions of what the text meant are partly shaped by what we think it means now. The very business of interpretation is not hospitable to any notion that 'description' and 'normativity' are mutually exclusive. In short, the attempt to force a division between what the text meant and what it means is illusory, for what meaning means itself is far from clear!115

It is not hard to see the wider influence of Stendahl's hermeneutical drive. Those following Stendahl's programme explicitly, such as Heikki Räisänen, call for a strict division of labour between the work of the Biblical scholar and the theologian, and there are many others implicitly infunenced who try to do New Testament

\footnotetext{
112 Bart, 1999, 189-208; Ollenburger; 1986; Lash, 1985.

113 Stendalil, 1984, 10. This metaphor reveals a historicist prejudice - that there is one recoverable historical meaning to texts and that this should in some sense limit all other meanings.

114 Stout, 1982, 8. Stout continues (on the same page), "Let us then celebrate the diversity of interpretations as a sign that our texts are interesting in more wiys than one,'

${ }^{115}$ Frequently, however, Stendahl displays a robust hope that he can divorce himself from the history of effects of the text, that somehow, he as a Biblical public health officer can get at the original meaning. free of all the mennings which have contaminated the text. For such optimism sec his belicf that, "the more intensive the expectation of normative guidance and the mort sxicting the claius for the holiness of the Suripturs, the rnore obvious should be the need for full attention to what it meant in the time of its conception and what the intention of its authors might have ben.' (Stenclahl, 1984, 9).
} 
Theology'. Having atready dealt with Donfried's analysis of the theology of 1 Thessalonians, we will now examine a theological interpretation emanating from a recent SBL consultation. We will examine to what extent such theological treatments are testament to the 'history of effects' of Stendahl's strikingly modem programme, ${ }^{116}$ a manifesto that talks of New Testament theology but delivers a history of early Christian thought.

The Pauline Theology Consullation of the Society of Biblical Literature, which ran from 1985 for ten years, commenced with the earnest conccrn that the theologies of Paul which were being produced in the 1970 s and 1980 s 'tended to reflect the theological perspectives of Paul's interpreters more clearly than the theological emphases of the apostle himself.'xt7 The Palline Theology Consultation group desired to get at 1'aul's theology as 'it came to expression in each letter', ${ }^{118}$ and so contribute to the task of understanding the mind and thought of Paul. Their work has been published in four volumes.

Earl Richard's contribution to the consultation, entitled 'Early Pauline Thought: An Analysis of 1 Thessalonians', follows (as the title suggests) a rigorously descriptive pattem. $\Lambda \mathrm{s}$ a feature of this interest, questions of background fascinate Richard, and certainly students of Paul interested in the background of his thought have a large field in which to play, with Hellenistic Jewish, Greco-Roman and Jewish Christian sources of thought all being important. ${ }^{11}$ From the commencement of his analysis Richard reveals his preoccupation with preparatory historical questions - debates about chronology, the relevance of Acts 17, the textual integrity of 1 Thessalonians itself (a tendency which breaks apart the final form of the text) ${ }^{120}$ and Hellenistic epistolary parallels. ${ }^{121}$

Despite the project's aim of getting closer to understanding Paul, there is little evidence in Richard's work that he has found himsclf 'in the grip of an event, a

\footnotetext{
${ }^{116}$ For the modernism within Stendahl's project scc Admm, 1995, 82-6.

${ }^{117}$ Bassler, 1991a, ix (Preface).

${ }^{118}$ Bassler, $1991 \mathrm{at}$, ix (Preface).

${ }^{119}$ Richard, 1991, 39.

${ }^{120}$ Where theologians (e.g. Watson, F., 1994a, 15-77) are interested in the final form of the canonical text, and in drawing out the implications it has as such, historians like Richard are more concerned to show the inconsistencies in the text and its gaps, holding to the interpolation of 1 Thess 2:14-16 (Richard, 1991, 43).
} 
happening, a disclosure, a claim to truth which we cannot deny'. ${ }^{12 z}$ It might be unfair to charge Richard with not reading 1 Thessalonians as a classic, for he makes no claims that this is one of his presuppositions. For Richard the background against which 'one must read the letter' is the community to which it was sent. ${ }^{123}$ Where we axe on terra firma is on criticising Richard's hermeneutical decisions. For there is in Richard's analysis a historicist tendency to silence any chance of conversation, by refusing to participate in the patient struggle and discovery that is the hermeneutical conversation. Richard sees the meaning behind the text, rather than the world in front of it, and as onc absorbed in historicist questions he remains deaf to the provocations and questions of the text. Richard thus silences the text, eliminating any chance of it questioning, provoking, or propositioning. Neglecting to read the text in line either with its (or Paul's) verifiable intention - as a witness to God's revelation - Richard fundamentally misreads the text's full potential.124

A purely historical-critical understanding of the text represents what David Tracy Lerms a 'methodolog[y] of control', ${ }^{125}$ a methud by which Richard ensures he remains impervious to the provocations of the text which would pull him into its understanding. In Richard's analysis the historian remains in control, breaking up the text into two letters - the so-called 'Early Letter' and 'The Later Missive',26' and interpreting the ethical exhortations against their I Iellenistic and Judeo-Christian background. ${ }^{227}$ Splitting up the letter might not have been so damaging if Richard had proposed a whole or a tunily to which these parts could be related, but for Richard there is no overarching whole to Paul's witness that is 1 Thessalonians.

In many ways, then, Richard, is a faithful disciple of Stendahl, committed to a 'descriptive approach',128 free from the ecclesial confusions resulting from immersion within the text's form and reference. By setting himself the task of description from the beginning of his study, Richard remains in control, never really letting himself be governed by the flow and form of the text, breaking it up as an

\footnotetext{
121 Richard, 1991, 42.

122 Tracy, 1981, 114.

${ }^{123}$ Richard, 1991, 48.

${ }^{124}$ cf. $C O \mathrm{~V} / 2,493$. The theme of witness, and its importance to this thesis, was introduced in the thesis' introduction, and is followed through more thoroughly in $\$ 3.3$ below.

${ }_{125}$ Tracy, 1984a, 297.

${ }^{126}$ Richard, 1991, 49-50.

${ }^{127}$ Richard, 1991, 50.
} 
extra measure, lest it exercise any such authority over his interpretation. In the historicist mindset of Richard the text's meaning is exhausted by its historical significations. By imposing the Stendahl grid, a distinction which encapsulates the motivations behind our first crilique, based on the premise that the prinnary task is to establish historical meanings in detachment from contemporary meanings, Richard both contains and limits the text's full potential.

Our examination, and preliminury critique, of Stendahl's and Richard's work, leads to our first critique: historical-critical studies operate with a limited notion of meaning and tuth. Allies from both non-theological and theological perspectives will consolidate this thesis.

Considering that the texts which the historical critics expose to historical scrutiny are themselves part of a rich history of meanings within (and outwith) the church it is profoundly ironic that historical-critical scholars have given so liltle attention to their own rootedness in space and time, of the fact that they too are part of the texts' common history of intexpretation. ${ }^{129}$ Ilistorical critics have applied insufficient critical attention to their own interpretative location, as the intellectual historian Dominick LaCapra highlights, 'the past is not simply a finished story to be narrated but a process linked to each historian's own time of narration.' 130 'The irony of historical-critical scholars being insufficiently attuned to their own historicily, and participation within history, is palpable. ${ }^{13 \pi}$

The reluctance of many Biblical scholars to discern how rreaning in a text is linked to our present situation is widespread. Examples of this malaise abound in historical re-constructions of the New Testament, not least in 'Historical Jesus' research. Critics often point out that the Jesus established by the historians' toil often turns out to be a pale reflection of the historian's social and political outlook: a politically

\footnotetext{
${ }_{128}^{128}$ Richard, 1991, 39 n.J.

${ }^{129}$ The problem is exacerbated by an ever expanding knowledge of the context of the Biblical writings which push historical critics more and nore in the direction of genclics (for which see Barton, J., L998, 9) - of understanding Biblical documents by means of where they came from - with little or no connection to how the text develops once it is out of the hands of its author. See Gadamer, 1975, 299, for similar criticisms.

${ }^{130}$ LaCapra, 1983, 18.

${ }^{131}$ So Tracy, 1984a, 295, 'every interpreter enters into the act of interpretation bearing with her or him the history of the effects. both conscious and unconscious, of the traclitions to which we ineluctahly belong.'
} 
involved and radical Cynic divested of any eschatological or apocalyptic teaching is common to many contemporary North American constructions. Writing of Harnack's nineteenth century Liberal Protestant re-construction of the historical Jesus, George Tyrell's comments are still strikingly apposite to our situation, 'The Christ that I-Iamack sees, looking back through nineteen centuries of Catholic darkness, is only the reflection of a Liberal Protestant face, seen at the bottom of a deep well. ${ }^{\prime 132}$

'Historical Jesus' research is a good example to highlight for another' reason, for it brings to light many of the complex issues surrounding faith and history. ${ }^{133}$ Much historical Jesus research works with the assumption that historically established facts can be translated straight into Christological truths. Indeed, the crusading ethos of the much-maligned Jesus Seminar would appear to be that the 'truth' of Jesus is established only via historical purity. The reality is that behind reconstructions of the 'real' Jesus have often been lurking subtle, or not so subtle, Christologies. L.T. Johunson, writing of the recent attempts to locate the historical Jesus (with the Jests Seminar particularly in his targets), aptly comments on the theology lurking behind such quests,

'there is the assumption that origins define essence: the first understanding of Jesus was necessarily better than any following; the original form of the Jesus movement was nat:urally better than any of its developments. ${ }^{\prime} 134$

Much historical-criticism operates wilh a remarkable dissonance between the critical energy applied to the texts and the critical energy applied to the current context of interpretation. I Iowever, this is to assume that the texts are part of a rich world of meanings, that in our moments of location, oux interpretation must give proper weight to the 'excess of meaning' of which the text is constitutive, and that matter we now seck to demonstrate.

We have seen that many theologians and non-theologians read the Bible as a

\footnotetext{
${ }^{132}$ Tyrrel1, 1913, 44.

${ }^{133}$ See Morgan, 1987.

134 Johnson, L.T., 1996, 55.
} 
'classic', a book whose meanings unravel over time, and a text whose power and potential is not exhausted by its original provenance. Historical-criticism, with its propensity to examine 'behind the text' is quite unequipped to examine the worlds of meaning that unravel out of and 'in front' of a classic text. It was the German philosopher, H.G. Gadamer in his Truth and Method, who most famously elucidated this aspect of the text, the Wirkungsgeschichte, or 'history of effects'.135 'The corollary of examining the history of effects of a text may well be a more rigorously attuned sense of the text's history, for as a classic text, the question of the text's history incorporates questions of the text's historical effects, as much as it does questions surrounding the text's context of production. To read a classic text, as 1 Thessalonians is, without space being given to the worlds of meaning provoked by a reading within, marks a faiłure to engage with what is most proloundly enduring within the text.

Our interest with history is therefore in line with the Church historian, Karlfried Froehlich, when he commented,

'I have become convinced myself that historical 'understanding' of a biblical texl cannot stop with the clucidation of its prehistory and of its historical Sitz in Leben, with its focts on the intention of the author. Understanding must take into accourt the text's posthistory as the paradigm of the lext's own historicity, i.c., as the way in which the text itsell can funclion as a source of human selfinterpretation in a variety of contexts, and thus, through its historical interpretations, is participating in the shaping of life.' 136

An exemplar of a Biblical scholar who is interested in precisely these questions is Yvonne Sherwood, author of $\Lambda$ Biblical Text and its Afterlives: The Survival of Jonah in Western Culture. ${ }^{137}$ Sherwood is self-consciously writing against the grain of a guild still largely enthralled by historical-critical questions. For Sherwood, however, Biblical texts are always 'sustained' by interpletation, for so potent a force is

\footnotetext{
${ }^{135}$ Gadamer, 19\%5, esp. 267\%74, 305-41.

${ }^{136}$ Froehlich, 1991, 9.

${ }^{137}$ Sherwood, 2000. It is worth noting, however, that no reference is made to any interest in the kinds of hermeneutical questions Gadamer was raising. Sherwood's interests ate less hermeneutical, and more involved with Cultural Studies, Jewish Studies, and Literature and Art.
} 
interpretation that it 'overwhelms, eclipses, and alwoys precedes the biblical 'original'.138 The study of Jonah and its afterlives reveals that knowledge and meaning in relation to Jonah as a text are 'agglutinative'.139

Sherwood's book is a fascinating catalogue of the various interpretative contortions (as she regards them) the book of Jonah has experienced in the hands of both Jewish and Christian interpreters. Under the interpretative hands of the Fathers, Jonah is interpreted typologically, as a sign pointing towards Jesus and, subsequently, a living representation of 'carnal' Israel.140 II, in the interpretations of Augustine and others a creeping anti-Judaism can be detected, so too, in the hands of the Reformers was the text used and deployed with political and strategic ends in mind. ${ }^{141}$ And, in the nineteenth century, the text was subject to all sorts of fantastic and ingenious interpretative strategies with those anxious to read the narrative as God's scientific textbook. ${ }^{142}$

For Sherwood, the interest lies in the sheer weight of intexpretative positions and strategies the text of Jonah can bear. For her, the stimulation does nol lie in the historical origins of the text, but in the rotation of the various interpretations, which reveal the text to be 'a gigantic echo chamber'. ${ }^{143}$ The history of effects, of which the text is constitutive, is an alienating process, requiring the deconstructive skills of an archaeologist of interpretation. For Sherwood, such an examination of the history of effects reveals the text in a less than flattering light, 'T am left holding a heavily encrusted, rusted, text, covered in barnacles and ideas that hold on, like limpets'. ${ }^{144}$

Sherwood is clearly a non-theological partner, who does not talk of revelation, but of deconstruction. Neverthelcss, in her inplicit criticism of historicist tendencies, and her commitment to establish how the text gathers and grows in meaning over time, she is an ally for whose company we are grateful.

Theologically, what we are calling for in this argument is a close attertiveness to the

\footnotetext{
${ }^{138}$ Sherwood, 2000, 2 (emphasis original).

${ }^{13}$ Sherwood, $2000,5$.

140 Sherwood, $2000,11-21$.

${ }^{1+1}$ Sherwood, 2000, 32-42.

${ }^{142}$ Sherwood, 2000, 42-8.

1.43 Sherwood, $2000,78$.
} 
ultimate witness and reality of the Biblical lext - something requixing scrupulous clarification - that is constantly generative of new readings. The revelation of the text, its subject matter, is that to which the text is witness. Historical-criticism confuses the text's revelation with its original moment of delivery, as if somehow the factuality of the text's origins represented its revelation. Reading the revelation of the text's witness as God's revelation, this revelation will always transcend our attempts to freeze it into any one historical context. The difference here, with a nontheological ally like Sherwood, is worth pointing out. For where we too may be interested by the kind of questions regarding reader-response, 145 theologically we will want to speak of the generative revelation that is God in Christ.

Historical-criticism is therefore not criticized because it isn't necessary, for the Biblical texts are indisputably historically constizuted texts. We can and must say that in 1 Thessalonians the text acted as witness to revelation, and this canmot have happened in anything other than a historical moment, for revelation always 'lus its time, and only in and along with its time is it revelation.' ${ }^{146}$ But reading 1 Thessalonians as a text witnessing to revelation asks us to read a text witnessing to the 'Lord of time', the one in whom all time finds (or will find) its uxity. 1 Thessalonians points to a God whose capacity to reveal in different times is boundless. Our critique of historical-criticism revolves around the limits of its vision, limitations which hinder the historical critic's attempts to get at the enduring truth of the text, a truth outwith the historicist's horizon.

Those who perceive a mutually constructive relationship between ekklesia and text, cannot read the Bible like 'any other book'. It is because historical-criticism is chronically ill susted to reading the Bible with such sympathy that it will be limited to a marginal role in any explicitly theological interpretation of the Biblical texts.

Working towards an tunderstanding of the text's meanings is possible only through a hermeneutical dialogue between the text's revelatory subject matter (disclosed from within the text) and each new context in which the text finds itself part of new meanings, and is performed and interpreted. Such an approach undoubtedly signals

\footnotetext{
1.4 Sherwood, $2000,87$.

${ }^{14.5}$ Sherwood, 2000, 48-87.

${ }^{1.16} \mathrm{CD} \mathrm{I} / 2,50$.
} 
a departure from any putative 'authorial intention'. The assertion - that the original context and authorial intention is not normative in the quest for meaning - is as alien to Stendahl as it is heresy to most historical-critical scholars. ${ }^{147}$ In reality, all we are calling for is a realization that in writing 1 Thessalonians the apostle Paul witnessed to realities which he could neither control or contain (in this sense he really perceived them). ${ }^{148}$ Allowing these realities of revelation their proper freedom, what 1 Thessalonians points to acts as host for an abundant ficld of meaning.

Historical-critical scholars not only suppose they can, but also demand, that the text is divorced from the situation of its interpreters. The text is read as alien, divorced and separate from our context - it is put at a distance. What we have been arguing is that such a project is tunrealistic and limited. The truth of revelatory texts like those of Scripture is to be discerned not by merely casting them into their original situation but by repositioning their eternally valid revelatory power - to which they witness - in the living stream of the community that holds them as atthoritative. The truth and meaning of 1 Thessalonians resides within the relationship of crealive tension between the text, the world of meanings opened up by the text, and its faithful location within the worship, life and tradition of the church. ${ }^{149}$ Within this setting, Paul's authorship of 1 Thessalonians is only a preliminary concern to the secondary role that the texts can and do play in hermeneutical conversations. Far from the meaning of the texts being frozen in one time, and in one context, the texts of the Bible find themselves in the canon because they have found themselves consistently able to speak from their particular context to our context.

This first critique, therefore calls for an end to the bifurcatory tendencies dominant

\footnotetext{
!47 Typical of the confidence displayed by Stendahl is 1962 (2000b), in Stendahl, 1976, 96, we find him writing of the possibility of the biblical orginal functioning 'as a critique of inherited presuppositions and incentive to new thought.' The seemingly normative nature of Stendahl's descriptions is typical of the confusion of his project.

Jeffrey Stout is sanguine about the variety of interpretations a given text will be able to bear. Interpretations of religious texts, insofar as they have acquired meanings independent of the author's original aims, may well require interpretations that mark a departure from the strict "authorial intention'. See Stout, 1986, 110, on apostolic letters, 'you will probably want an interpretation you can ascribe to the community for which the letter functions as Scripture, thereby helping explain the community's behaviour under circumstances unlike the author's own.'

${ }^{148}$ See Barth in $C D 1 / 2,543$, where apostles are tescribed as "recipients of revelation in the sense that revelation meets them as the master and they become obedient to it."

149 'The term 'tradition' is another tertu heavy with possible meanings. See Brown, R.M., 1961, $212-4$. Here we are deploying it not to reter to official pronouncements from the Magisterium, but in the widest sense, to point to the clurch's ongoing rcading of Scripture.
} 
within Biblical studies, epitomized by Stendahl's (in)famous distinction between 'what it means' and 'what it meant', and found most recently in Heikki Räisänen's work. ${ }^{150}$ Far more fruitful, would be to construct a model of interpretation with an indisputable centre, whilst committed to a process of continual refinement and infinite progression. In such a hermeneulical conversation now one voice will be heard to speak, and then another, but all the participants will enjoy an organic relationship, where previously an unrealistic 'relay-race model' reigned. 51 Nicholas Lash, in response to Stendihl, embodies much of what we aspire to when he wrote,

\begin{abstract}
'we do not first understand the past and then proceed to seek to understand the present. The relationship between these two dimensions of our quest for meaning and truth is dialectical: they nutually inform, enable, correct and erlighten each other.'152.
\end{abstract}

What is called for, therefore, is an integrative conversation driven by an imaginative fidelity to the witness of the texts. ${ }^{153}$ Within this conversation guided by the witness of the text it is quite proper to read 1 Thessalonians in the light of later Christian tradition. Indeed it will prove to be disclosive of new meanings within the text, for the real fallacy lies in supposing that historical truth is attained by divorcing ourselves from our present context which, in truth, is like trying to flee from our own shadow.

Libcration theologians, distinguished by their critique of Western scholars for failing to realise entrenched ideological biases, further consolidate our argument against atomised ways of thinking. For liberation theologians the truth of Biblical texts is not to be garnered by the kind of twattainable disengagement with the ultimate reality of the texts which historical-crilicism preaches, but by a consistently

\footnotetext{
${ }^{50}$ Rhisänen, 1990. See, most recently, Raiistimen, 1998, 124, "The goal of a history of early Christian religion is not to proclaim a message. It tries to inalyse and to understand",

151 As set out by Lash, 1985, 16-17. Cl. Green, J.B., 2001, 313, on the relay-race model: 'Exegesis leads to biblical theology, biblical theology leads to systematic thenlogy, and systematic theology leads to ethics.'

${ }^{152}$ Lash, 1979, 25.

${ }^{153}$ It is worth noting that imagination mny be properly seen not so much solely as a theolugical skill, but one also needed by historians. Gadamer notes how historians are called upon to employ their imagination insofar as they are implicated in a lively dialogue between the past as it is, and a present shaped by their presuppositions that, in turn, are shaped by past events. For Gadamer, tlerefore, imagination is 'the decisive function of the scholar' (Gadamer, 1976, 12). For Lash, 1979, 21, imagination is nothing less than 'the intellect in quest of appropriate precision'.
} 
engaged reading of the subject matter of the texts that manifests itself in praxis and performance. ${ }^{154}$ Moreover, many liberation theologians remain suspicious of what one distinguished practitioner terms 'semantic positivism', an attitude which freezcs the meaning of the texts into controlled etymological understandings, so they can be deployed at will. For Clodovis Boff, such a technique heralds all the living relevance of a 'museum', all the fertilily of a 'cemetery'. ${ }^{155}$

Miguez bonino equally criticises the Western atomisation of truth as theory and, separately, truth as application. For Miguez Bonino, the Western mindset is hindered by a belief that first the thcoretical conceptions of truth have to be worked out, and then this truth is to be applied in concrete historical situations. The brunt of Miguez Bonino's criticism is that in the Western mindset there is no belief that the applicatory role can play a corrective role to the theoretical conceptions, theoretical truth representing 'a universe complete in itself.'156 And, of course, in his highlighting of the importance of the comununity which performs and interprets Scripture Miguez Bonino is not alone amorgst liberation theologians. For Boff, likewise, 'Priority is to be accorded to the value of the real practice of the community over that of any theoretical elaboration.' 157

Whilst liberation theologians are primlarily reacting against the intellectual obscurantism of the Western academy, it is not hard to see the parallels with our critique of historical-criticism. Liberation theologians provide us with two central insights. One, just as historical critics have divorced themselves from the story of Biblical performance that is the theological and spiritual tradition of the church, they must stand with the Western theologians critiqued by Miguez Bonino who attempt to construtct a world of truth 'complete in itself.' 158 Where Migue $z$ Bonino and his associates talk of exegesis marrying with praxis, it is equally imperative to construct a similar relationship between the text and those contributions which might serve to illuminate the witness of that text.

And so secondly, liberation theologians helpfully talk of understanding the

\footnotetext{
154 e.g. Miguez Bonino, 1975, 99.

${ }^{15 s}$ Boff, 1991, 15.

${ }^{156}$ Miguez Bonino, 1975, 88. Cited by Luz, 1994, 16.

${ }^{157}$ Boff, 1991, 32 (emplassis original).

${ }^{158}$ Miguez Bonino, 1975, 88.
} 
meaning of Scripture within the life of what Clodovis Boff terms 'the living spirit of the living commutuity, ${ }^{\prime 15}$ from within the mystery-laden and mutually dynamic relationship between Scripture and the sensus fidelinm.

Theologically, therefore, we are keen to assert that the truth of the text is not be located here or there, but is worked out over time. The reader is thus called to a dialogue with the text, reading the text itself in the richness which the time of the church offers. As we read the text we inevitably read in our time, with our contextual concerns and questions, and hope to be encounlered by a text that reminds us that there is more at work than just our time. Theologically, the revealing truth is not the text itself (as per historical critics and Biblical literalists), nor in the original context of textual production, but in the act of reading the text in the time of the faithful community produced, sustained and nourished by the Word. Truth thus lies in the discernment of how the God, who through the incarnation has interwoven himself amidst our time, can bring that which the text speaks of to new meanings and understandings over time, through time and history itself. Correspondingly, the process of discernment takes place in time and through the unfolding history of theological tradition. Meaning and truth, in short, are produced over time, and therefore carunot be fixcd to any one point.

Such a reading of 1 Thessalonians is possible only by accepting two presuppositions.

First, as was emphasised in our preliminary definition of revelation, the excess of meaning is possible precisely because we are dealing with a text faithfully witnessing to revelation. As was argued above $(\S 1)$, it is in the very nature of revelation to be always spilling out, over and beyond its context of production. To acquire what Biblical scholars and theologians alike call a 'Scriptural imagination', 160 is to read the text with eyes open to realities continually indicated by the text. So, we will find that this theological assertion is unmistakably related to our understanding of inspiration within the co-constitutive relationship that inheres between church and Scripture. Attesting that we too can be participants within the

\footnotetext{
${ }^{159}$ Boff, 1991, 14.

${ }^{160}$ For theologians calling for such an imagination see Lindbeck, 1989; 1988a; 19881); 1987; 1986, for a Biblical scholar calling for such an approach see Johnson, L.T., 1998.
} 
living stream of Scriptural interpretation, is to attest that we too can be part of a community where God ceaselessly discloses his purposes for the church and for the world, where God's revelation is experienced and can be (deficiently) articulated as a dynamic flow of grace.

Secondly, to recognise a contintuity between the specific time of 1 Thessalonians and our time is to recognise and affirm that the contemporary church is united to the same grace to which 1 Thessalonians points. Where the historicist examines the text with the presupposition that il is necessarily alicnated and different from our interests, the ccclesially situated reader must assert in reaction the essential continutity that inheres between the interpretative location of the church now, and the church we read of in the texts. ${ }^{161}$ God is perceived as working through time, not just in one time, for the benefit of increased and sustained communion. The Biblical texts, therefore, will be tunderstood as creative of meaning then as much as they are now continually re-creative of meaning. Such a perspertive is likely to transcend the concerns of historical critics in locating the meaning of the text in its originat context.

In summary, historical-criticism is predisposed to militate against the polyvalent meanings of the text, preferring single meanings, where the text is host to a wealth. of diverse meanings over time. Where historical-criticism treats the text as productive of a single historical meaning, in a particular context, we replace this model of stasis with a model sensitive to the rich production of meaning through the interpretalive traditions that emerge over time.

The approach we have outlined here, rooted in an affirmation of the mutually corrective and supportive relationship between Scripture and church - insofar as the church is energised, defined and generates new levels of understanding of Scripture's essential subjed matter - has two, closely related though subtly distinct implications.

First, as was stressed above, insofar as we are committed to historical understandings of the text, we will want to sustain a lively interest in the church's

$\overline{{ }^{161}}$ So, Jenson, 1999, 98, "the text we call the Bible was put together in the first place by the same 
Iradition which has amplified the text's profundity. From this perspective our readings of Thomas' and Calvin's commentaries on 1. Thessalonians emanates.

There is, however, a second corollary. In many ways this implication is quite distinct from the previous implicalion, for a conversation with the text, a conversation shaped by the text's inherent subject matter, must be gentuinely dialogical, allowing now one voice to speak, and then letting another voice to be heard. Both the text and the stibject matter will be absolutely regnant. Theologically, our conversation will be given its integrity by ceaseless fidelity to the text's subject matter, that which is disclosed purely and only by the text. We will be looking for something more than the Rezeptionsgeschichte of the Biblical texts, because we will be seeking roadways into explorations of the text's profundity, a profundity that is of necessity present because this is a text attested to be witnessing to revelation.

Relating this model to 1 Thessalonians compels us to think imaginatively, confident that we are inheritors of the same dynamic of grace communicated to the Thessalonian Christians. Such a mindset calls us to grapple with the same issues they were grappling with, being absolutely gripped by the same subject matter Pat: was gripped by. In such a way not only is it possible to come to terms 'with a notion of truth much larger than the purely historical', ${ }^{162}$ but through this faithiful imagination to work towards a theology that discloses how the same subject matter that generates 1 Thessalonians can be explored in its endless profundity in the context in which we are now located.

3.2 Historicism freezes the eschatological language of Scripture into a reflective relationship between text and original context

Our second complaint with historical-criticism is closely related to the first. There is a dangerous and urspoken bias prevalent within historical-criticism to which we need to be alert. The assumption of much historical-critical methodology is that the text is a mirror of the world in which it was written, an assumption in line with reading the Scriptural text as sources. Not only does this have a tendency to freeze the text's meaning into one particular context (a point which we have noted above), but it also assumes an unsophisticated correspondence between 
experience and language, seeing language merely as a translator or filter through which we feed our experiences. In this perspective the language of Scripture becomes a purely passive player.

Reading the documents of the early church as mimetic aids to sccing into the lives of the communities (putatively) belind them, divorces the texts from their participatory and reciprocal roles they have the capacity to play in the communities in which they took shape. Our allies here are nol just theological. Jean Howard, writing of the new historicism in Renaissance studies, wams of the danger of ignoring the extent to which texts can constitute history, as much as they can reflect it. ${ }^{163}$

The assumption of historical-criticism is that the language of the New l'estament is a reflection of the experience of the early Christian communities, language being a mirror into which inquisitive historians can peer. Historical critics are thus predisposed to reading texts as reactive to situations within their communities, rather than a medium through which God himself works his continually creative will. This predilection is not surprising given that history is a subject generated and sustained by questions of causality, questions that ask how, why and when certain events happened. In pursuing these questions of causality the text is constrained within an assumed continuum of cause and effect. In the historicist mindset of analogy, there is little or nothing in the lext lacking the potential to be explained in terms of prior circumstances or contexts. For the historicist it is the constructs of historical inquiry, rather than the church's unfolding of revelation which makes sense of the Bible's languagc.

The argument here pivots around the concern that historical critics read the language of Scripture as pointing back to putative thought-processes and worldviews, where theologically it is imperative to press the text forwards into the world which the language of Scripture simultaneously proposes and expands. There is, in this sense, an eschatological fullness and ripeness to the language of Scripturc, the full meaning of which is only brought about through the church's everexpansive time of reading. Just as the revelation of Christ is complete and

\footnotetext{
162 Brown, D., 1999, 282.
} 
unsurpassable, but nonetheless is progressively amplified through time, so too is the fuliness of Scripture present from its genesis, but it too is progressively understood and comprehended through its inexhaustible reading,

'The germ found in Scripture is the seed; tradition is the harvest which pushes thurough the soil of human history.'164

Given out claim that there is at work in the language of Scripture the promise of eschatological fullness it seems highly pertinent to examine historical-critical readings of Paul's directly eschatological discourses. ${ }^{165}$ We will choose as our exemplar Ernest Best's commentary on the Thessalonian correspondence. Best does not clain that his work is theological exegesis - his interests are purely textual, grammatical and historical. We will, therefore, base our critique not so much on what Best writes (for it is not our business to carp at excmplary scholarship), but on what he doesn't write, and on how his omissions are dictated by his presupposition that 1 Thessalonians is a historical source to be mined for background information.

1 Thessalonians 4:13-18 is clearly the most eschatological section of Paul's text, a section Best refers to as 'The Dead and the Parousia'.166 In this section, historical context is clearly not unconnected to understanding the passage, but it is far from the whole task facing us. Whilst it is important to recall that Paul wrote these verses with the Thessalonians in mind, as our previous arguments indicate, what is more interesting for a theological exegesis is examining the new worlds of understanding the text itself has opened up, quite independent from its original context. It is clear, however, which position Best is predisposed towards: the text is a reaction to events in Thessalonica, and the text can be read as a mirror through which Paul's purpose is faithfully reflected. Thus, for Best, 'l'aul's primary purpose in writing is not to enunciate doctrine but to reassure ${ }^{\prime 167}$ the Thessalonian Christians. Patul is read as a lusstorically grounded purveyor of well-chosen advice, a reading which misses the excitement of reading $P$ aul as an apostle with a timeless message.

\footnotetext{
${ }^{169}$ Howard, 1986, 25.

164 Bulgakov, 1935, 29. Organically sounding conceptions of the increasing understanding of the church come under attack from Gunton, 1995, 95-8.

165 Best, 1972.

166 Best, 1972, 179.

${ }^{167}$ Best, 1972, 180.
} 
A symptom of historical critics' reltuctance to interpret the eschalological potential of Scripture's language is a fervent interest in the world behind the text (the etymology of specific words, the background of concepts, the context of utterances) which clouds out any possible interest in the world proposed by the text. Whilst this is certainly not reading the Bible in line with its classic status, in line with its inexhaustible interpretation, it is equally not reading it in line with its role as revelatory Scripture, texts which the church attests to as holding an abiding revelatory significance.

In reliable historicist fashion, Best understands the texts solely by means of the words' background and etymology. Best shows understandable interest in the background to 'sleeping' (4:13), tracing its meaning back to the Old Testament, but there is little evidence that pushing the word's meaning further and further back into history is necessarily the best, and definitely not the only way, to perceive that to which the texl witnesses. In Best's approach the only semantic depth words cnjoy is by pushing them back into their pre-history, and into the likely meanings which Paul intended, but not into the lives they come to enjoy in successive interpretative communities. This curator-like drive to 'reconstruct the original form' of words contrasts with the reading we propose in part III where we explore the meaning Christian tradilion has discerned in the reference to the sleeping (rompiousvos) Thessalonians. ${ }^{168}$ In Best's commentary, however, no space is given to the text's performance within the reading community of the church. ${ }^{16}$,

Best's over-riding interest in the historical origins of the words of the text rises to extremes in some cases, for in eschatological material there is much to occupy the industrious historical critic. Biblical eschatology brings with it its own jargon, words which tease the historical critic, and sap all his energies. But if Bost satisfactorily exposits the background of such words 'archangel', 'trumpet', 'clouds', 170 there is no interest in extending the words' meaning forward into their eschatological fullness. Even in his concluding postscript on eschatology, where most historical critics would try (perhaps ineplly) to translate their historical findings into some form of theology, Best keeps firmuly to his own 'patch.', giving yet more information on the

\footnotetext{
${ }^{168}$ Best, $1972,189$.

${ }^{169}$ Indeed where ancient commentators are cited they are trented dismissively, and are said to have avoided the 'plain meaning' of the text: Best, 1972, 195.
} 
It needs to be stressed that we are not criticising the actual findings of Best's commentary. His close rcading of the Greek speaks of a serious responsibility to the text. Ultimately, however, our presuppositions and Best's are divergent. For Best, the texts are sources, to be dug into for their meaning and correspondingly he provides the reader with a pre-history of Paul's eschatological images. Theologically it is necessary to insist that any eschalological assertions we want to make on the basis of 1 Thessalonians, must rest not on scholarly hypotheses surrounding Patt's influences, but rather through studied and loyal attention to what is indicated in the actual text.172. Such presuppositions are somewhat different from Best's, for in particular, we are aroused by the witness of the text, not in the manner of a historicist seeking past meanings, but in the search for continually expansive meanings. With this perspective, the limited value of Best's commentary in relation to our interests become evident.

The limitations of Best's project will be brought to sharper focus by comparing his findings with that of Karl Barth's rcading of Romans 8:18-25, in the second edition of his Romans commentary.173

Barth locates the meaning of the passage in his grappling with the subject matter as it arises from the final form of the text. Thus, the background to the words Paul uses does not distract him, and he constantly refers to Patl, as 'the writer' as if in an effort to help the reader focus on the text in hand.174 Part of Barth's task is to demolish any hints of religion, any suggestion that we can conceptualise or contain God in our image or desires. There is no direct knowledge of God.175 Such a God is really a 'No-God' ', a false step from 'the true and Unknown God.'176 Given this absolute and utter distinction between hummity and God, Barth is theasy with Paul's use of 'I reckon' (Rom 8:18). Where Paul can say this as an apostle, we must

\footnotetext{
${ }_{170}$ Best, $1972,197-9$.

171 Best, 1972, 349-54.

${ }^{172}$ cf. Yeago, 1997, 95-6.

${ }^{173}$ Barth, 1933a.

${ }^{174}$ So Jülicher, 1968,81 , "Much may someday be leanned from this hook for the understanding of our age, but scarcely anything new for the understanding of the 'historical' Paul.'

175 Barth, 1933a, 314, 'Direct communication from God is no divine communication.'

${ }^{176}$ Barth, 1933a, 303. Cf. McCormack, 1995, 246-9.
} 
invert this statement, "God reckoned with $\mathrm{me}^{\prime \prime}, 177$

Provoked by the content of the text, Barth is seeking an answer to the question, 'What place does stiffering, that vast and immeasurable factor of himan life, occupy in the context of our Sonship?' ${ }^{\prime 7 \%}$ Any answer to this question must base itself on the radical distinction between God in heaven and humanity on earth. All knowledge we have is inherently dialectical,

'it is precisely our not-knowing what God knows that is our temporal knowledge about God, our comfort, light, power, and knowledge of eternity.' ${ }^{179}$

It is suffering, and its eschatological resolution, which fires and provokes Barth throughout most of his commentary on this section, and he seeks to find the answer in God, in whom twuth resides. Not surprisingly, Barth finds part of the answer in Christology, 'the secret and the revelation of suffering', through which it is revealed that in our sharing of Christ's suffering we are promised the hope of his deliverance. 180 Our present sufferings are representative of nothing less than the frontier where this life is dissolved by life etemal.' 181

Barth relates the modern drive to explore and discover the extremes of the world to his commentary on $8: 19$, a verse which taks of creation waiting for the manifestation of the sons of God. Barth relates our modern angst to the resolution. that will be offered by God, urging his readers to see, through the text, the need to come to terms with the optimism by which we refuse 'to see the vanity of the creature'. ${ }^{182}$ Eschatology, for Barth, is thus a matier of perception, of knowing and seeing rightly where the world is heading, that the world is in God's hands. As Barth puts its, "We must recover that clarity of sight by which there is discovered in the COSMOS the invisibility of God.'183 And the same God, precisely as God, who subjects us to vanity is the same God of hope, insofar as we apprehend that 'All

\footnotetext{
${ }^{177}$ Barth, 1933a, 303.

${ }^{178}$ Barth, 1933a, 304

${ }^{199}$ Barth, 1933a, 310.

${ }^{800}$ Barth, 1933a, 305 .

181 Barth, 1933a, 305.

182 Barth, 1933a, 308.
} 
those things which are so manifestly observed by men are hidden in God.'184 Barth's eschatology is based on a radical time-eternity dialectic, an assumption that elcrnity is a state free from the constraints of time. Consequently, whilst eternity can never become time (for it would then cease to be what it is), it can encounter or graze any and all moments of time in equal measure. ${ }^{185}$ This is what Barth means with his persistent juxtaposing of Now, time, and eternity, 'the 'Now' which is time's secret'. ${ }^{186}$ So also Barth writes of this 'Now', 'that it bears in its womb the eternal, living, tunborn Future. ${ }^{187}$ This grazing of time with eternity (the 'Now') is a perpendicular irruption of timc, the meeting of eternity with time which is both radically distant and near. 188

Hope, for Barth, is 'to dare to think what God thinks', ${ }^{18)}$ and we wait in expeclation because we see what 'to us is invisible'.190 But, above all, we know, that the world of sorrow in which we wait, is linked to the sorrow of the cross, the locus where God was revealed as God.

The distinctiveness of Barth's treatment of this eschatological pericope from Romans is clear. True to his stated intention in his 1920 lecture, 'Biblical Questions, Insights and Vistas' he has put the findings of historical critics 'behind' him. ${ }^{191}$ The findings of histurical critics are unstated, though are clearly in the background of Barth's commentary. In contrast to Best, however, what Barth reads in and through the text is nol Paul's context, or the background of the words which he employed. Barth reads Paul not as a historical source, but as a witness to an eternal 'truth', ${ }^{192}$ that all Christian theology must be based on a consistently eschatological outlook,

'If Christianity be not allogether restless eschatology, there remains in it no relationship whatever with Christ. ${ }^{193}$

\footnotetext{
${ }^{18.3}$ Barth, 1933a, 309 .

${ }^{184}$ Barth, 1933a, 309.

18.5 MeCormack, 1995, 263-5.

${ }^{186}$ Barth, 1933a, 313.

${ }^{187}$ Barth, 1933a, 306.

${ }^{188}$ McCormack, 1995, 144, 164.

${ }^{189}$ Barth, 1933a, 314 .

${ }^{190}$ Barth, 1933a, 315 .

${ }^{191}$ See 'Biblical Questions, Insights and Vistas' in Barth, 1957, 51-96 (61).

${ }^{192}$ Barth, 1933a, 308.

${ }^{193}$ Barti, 1933a, 314. An insight Barth had gatnered from the early church historian Franz Overbeck (1837-1905). See Dulferth, 1989, for Burth's 'eschatological realism', especially $20 \mathrm{f}$.
} 
Reading the text as a witness to something totally other and beyond our range of perception radically upsets the assumption that there is a neat correspondence between the text and its original context. There is more at play and at work within the text than can bs adjudged by the historicist endeavour for origins. Thus where Liz states confidently, 'It is plain that ixh the disciples following Jesus into the boat, in the swamping by the setsmos, in the request kyrie soson, in the anxiety of the disciples or in their little faith, experiences of the community are reflected ${ }^{*}$, ${ }^{34}$ we would post a reminder of the contintually creative role the language of Scripture bears through time. Where our first criticism centred on how historical-criticism militates against the polysemous nature of the Biblical texts, this, our second cxiticism, focuses on the tendency of historical-criticism to ignore the creative roles of the text within both its original context and each new contexl within which it strives for revelatory value. For it is clear that texts merely understood as reflections of historical happenings are servile to, or in partnership with, a particular moment of history. In its transcendence revelation is always puncturing and interrupting history, continually speaking through history to conumunicate God's will and action. The Biblical texts are always much more than mere reflectors of their immediate social reality. Rather - in witnessing to God's revelatory will - they are always active participants in creating new realities. Both within their original locus of production and within the communities reading them as authoritative, the texts of Scripture are continually creative of new meanings, much more than they are mirrors which can be peered into by historicist scholars.

Our argument here is primarily theological, for we are talking about the very nature of revelatory langtuage, language with an infinite capacity to open out into successive 'presents'. Our assertion is that when we want to talk of Scripture we must talk of a text whose potential has transcended its original context, whose horizons are always wider than ils original context of production. This is to say that whatever Paul's historical intentions might or might not have been, theologically our interest lies with the abiding revelatory potential of the text in manifesting a 'proposed world'.195 In this sense the language of 1 Thessalonians, as Scripture, eludes its context of production and constantly seeks to speak in new contexts; thus the revelatory significance of the Scripture is only to be grasped through the

\footnotetext{
${ }^{194} \mathrm{Luz}, 1995,124$.
} 
church's lime of reading. In this perspective, Scripture is both the Word of God that creates the church, and Scripture itself is also formed in and by the church. ${ }^{196}$ The texls, far from bcing murky mirrors of their original context, are discourses striving for participatory, if not contestatory, roles, setting in motion an endless field of meanings. ${ }^{197}$ The focus here being largely the language of revelation, our criticism is that historical-criticism has a tendency to pass over the complex, and revelatory roles, language did, and does play in the life of communities where the text is taken up in performance. Reading 1 Thessalonians as a source, rather than as Scripture, historical-criticism unwittingly reveals itself as a profoundly limited exercise, because it neglects to read 1 Thessalonians in line with what it is really attempting to communicate, 'the Word of God which is al work in you' (2:13).

The revelatory language of 1 Thessalonians can therefore be cast in a mode of event and process. The event, whose voice is still to be heard, is that of the significance of God in Christ, as it impacts (in our instance) upon the Thessalonian church and beyond. Our argument here profitably draws utpon Ricoeur's formulation of the importance of the historical forms of revelation in the Bible, events whose historical significance is attested to by their 'transcendent character', 192 events whose meaning stand apart from the normal course of history. Moreover, Ricoeur does not shy away from the conclusion that the task of understanding the texts may lie in divorcing ourselves from the author's intentions. $19 y$

Modifying: Ricoter's seminal essay on the hermeneutics of revelation, we would assert that it is the language of Scripture witnessing to the perfection of God in Christ's revelation, more than the events of which it speaks, which are truly transcendent. It is not that there is anything special or revelatory about first century Thessalonica, only that Christ's significance as an event was set out in its first, primordial form in this place. But far from holding its meaning in any one fixed time the language of Scripture transcends even its original context of production. This is how Scripture is constantly experienced in the life of the charch. One

\footnotetext{
${ }_{125}$ Riceour, $1981,102$.

${ }^{196}$ See Jenson, 1994, 93.

${ }^{157}$ So, too, Green, J.B., 2001, 323f.

198 Ricoeur, 1981, 78.

${ }^{199}$ Ricoeur, 1981, 108. Sec the extended discussion in relation to authorial intention set out above in $\&$ 2.
} 
example might be Paul's statement in 1. Thessalonians 5:10 that the Lord Jesus Christ died 'for tus'. We cannot say that it was any part of Paul's historical intention to communicate this creed to early twenly-first century Christians. Paul might have been sharing this creed with the Thessalonians, but his language has been and is rclcased, taken on, and experienced by countless others. Paul's words, released into the life of a community endlessly tracing their own experience of a graced reality through the text, witness to a revelation radically free from any 'original context' or tentatively reconstructed 'authorial infention'.

Christian language, even Scriptuxal language, can only ever be an imperfect shadow of the real experience of graced transformation. Correspondingly, the language of 1 Thessalonians can only be inadequately understood from within an understanding of its original context. The least imperfect way to understand Scripture, as Scripture, is to wrestle with the process that is its unfolding over time. As we have seen, historical-criticism, marked by an objectivity predisposed against reading language as revelatory, that is in generating and sustaining new ways of perception and living, is bound to neglect this complex role played out by Scriptural language. Theologically, therefore, what we see in the text is less a mirror of an original context, and far more an expression of linguistic dissatisfaction with the inability of language to correspond to the 'power' (1:5) of God. For, as theologians, it is necessary to grapple with the Biblical text's charge of speaking of that which cannot be adequately spoken of in our limited langruage, God. In this way the words used by Paul reveal to the reader a hope of 'communication surviving the perils of words ${ }^{\prime}{ }^{200}$ and an awareness that we understand the langtage only in part against ils original context, and far more fully within every interpretalive context within which the language encounters, interprets and is brought to fresh expression.

The expansion of Scriptural understanding is thus experienced as a process, a process that enjoys a dialectical relationship with the event on which it is founded. To state this programmatically: the process of revelation is a continual unfolding of Christ's complete revelatory significance. God in Christ has commitled himself to time, and so enabled all time to be seen eschatologically, as constant expansion and

\footnotetext{
${ }^{200}$ Willians, R., 1977a, 182. This 1977 article and 'Trinity and Revelation' in Willians, R., 2000a, 131-47, have been extremely formative in the thoughts outlined here. The thoughts here are of course germane to the unlolding process of revelation within the life of the church we set out in $\$ 1$.
} 
progress towards the promise of eternity.201 The significance of God in Christ's revelation is something deepened and amplified through time, and never in any one time we prioritise - original context or otherwise. Where historical-criticism is interested in questions of text and original context, there is a greater theological need to relocate this energy in a drive to understand the revelatory language through the church which is continually prolonging, extending and deepening its understanding of Scripture's referent. It is through the text that we understand this imperative, for it is only through reading the text with attention and love that we come to see the limitations of understanding the language wholly against its original context. Reading the text, as a text through which God is continually willing to communicate, we will be seeking ways which help us engage with the revelation of the text in an ever expanding way, which connect us with the total effort of generations of believers. ${ }^{202}$

Lest the argument seems to have suddenly become opaque, it is important to clarify our meaning. The revelatory capacity of the Bible can only be grasped through time, rather than in just one moment, because the Bible speaks of revelation transcending the particular and communicating to all time. This is presumably what Barth was trying to articulate when he opened his first Romans commentary with the words,

'Paul, as a child of his age, addressed his contemporatries. It is, however, far more important that, as Prophet and Apostle of the Kingdom of God, he veritably speaks to all men of every age.'203

The meaning and significance of Scripture's texts cannot be wholly contained within any one time, for their revelatory capacity can only be unfolded through the church's ruminative reading. To be stre, this very process is only made possible because of the complete and unsurpassable event that is God's revelation in Christ. In Christ, God has entered into time and endorsed our time as capable of the text's creative reading and expansion. The inexhaustible richness of Scripture's language. is now to be rad in the context of the catholicity of the whole of time.'204 In this way, revelation as event and revelation as process far from being mutually exclusive

\footnotetext{
201 Stăniloge, 2001.

${ }^{202}$ Btondel, 1964, 244.

${ }^{203}$ Barth, 1933a, 1.
} 
are intrinsically bound together. Only because of the event do we become participants in the process. As we will see in our own theological reading of 1 Thessalonians (Part III), it is close reading of the text itself that engages us within the complex unravelling of revelation contained within the form of the words. The meaning that God has for any given Scriptural text is not exhatusted within the reflective relationship historicists construct between text and original context. The Scriptural text has more work to do in the church besides this for we have in Scripture 'a seed capable of progressive and continual growth.' ${ }^{205}$

\subsection{Historicism blinds historical critics to the text's apostolic witness}

Our third complaint in relation to historical-criticism is exclusively theological. To claim that historical critics are hampered by their historicism, and so fail to engage with the ultimate witness of the apostles is an argument likely to attract support only from theologians. Nevertheless, despite the potential loneliness of our quest, it is worth attempting to counter the presumption that the historical-critical mode of interpretation is really the most faithful and attentive reading of Scripture.

The assumption of much historical-criticism is that the most truthful understanding of the text will be achieved by an interpretation that puts the most distance between the modern reader and the world of the first-century church. This is the thesis evident in Stendahl and Räisänen: the church will only hear a new, possibly offensive voice, from the church of the past, if it commils itself to a maximal distance between the current context of interpretation and the text.206 However, in the desire to avoid the excesses of eisegesis, historical-critics may well be working with a defeclive model of exegesis.207 Exegesis, in attempting to bring out the meaning of a passage, requires the kind of open and frank discussion which commences with the presupposition that, at root, the texts we are excgeting, are texts whose meaning lies within their subject matler wilnessed to as true and valid in all times. In this key, Christ as the Lord of time, the one in whom all time

\footnotetext{
2014 'The Catholicity of the Church', in Florovsky, 1972, 37-55 (49),

${ }^{205}$ Blondel, 1964, 275.

206 Räisinen, 1995, 124, "Theology would gain from a distinction between historical exegesis and contemporizing theological interpretation; otherwise it runs the risk of only getting back from exegesis what it has first put into it.'

${ }^{207} \mathrm{cf}$. Walter Wink's charge that historical-criticism is 'bankrupt' (Wink, 1973, 1), based on the argument that it is not feasible to hold that the best readings of such subjectively engaged texts as the Bible's are always going to be objective ones.
} 
mysteriously finds ils purpose and unity, radically destabilises the distancing preached by historical critics. 2018

Prior to dealing with historical-criticism as it is actually practised, we will first examine a progranmatic article of Brevard Childs which assists in the clarification of the criticisms we will direct towards 1 Thessalonians scholarship. Developing our argument, we will examine Jeffrey Weina's work on the events 'behind' 1 Thessalonians 2:1-12, and examine how he completely misses that which is most striking about these verses: Paul's role as apostle and witness to God's revelation.

In his 1964 asticle, 'Interpretation in Faith: The Theological Responsibility of an Old Testament Commentary', Brevard Childs outlines many of his concerzs about 'the serious lack of good Old Testament commentaries' at the time he was writing.209 Childs is aware that it would be grossly unfair to judge commentaries by norms foreign to their guiding interests, to questions to which they are not seeking answers. Nevertheless, Childs is unashamedly interested in the scope of theological commentaries, and seeks the normative, as well as the descriptive categorics, which will sustain such a project. The questions which Childs asks are exactly the same questions which we want to pose to 1 Thessalonians scholarship, questions generated by out dissatisfaction with the historical-critical project: 'can the theological task of a commentator be exhausted when he remains on the level of the witness? Is there not a responsibility to penetrate to the substance towards which the text points?'210

For Childs, theological exegesis of the Old Testament would have three distinguishing features. First, it would be committed to reading a single Old Testament text in the light of the whole Old Testament, or as Childs articulates it, 'from the single text to the whole witness.' 111 At this stage all the traditional lextual and philological apparatus of the historical-critical method is brought to the fore the difference is that it is circumscribed within a theological matrix. Second, such a commentator will be committed to examining the inter-relationships between the

\footnotetext{
${ }^{208}$ For this strand in Barth's thought see Burnett, 2001, 108.

${ }^{200}$ Childs, 1964, 432 .

${ }^{210}$ Childs, 1964, 436 .

211 Childs, 1964, 440.
} 
Old and New 'l'estaments, for although they form a dual witncss they witness to the univocal purposes of God.212 Third, there will be a dialectic movement from 'strbstance to witness' and back again from the witness to the substance, ${ }^{213}$ a task which seeks to hear anew the Word of God. So, the task is here, to 'penetrate to that reality which called forth the witness', ${ }^{214}$ a task which surely lies al the heart of all theological exegesis.

Where do these obscrvations of Childs take us? Childs suggests that the mark of historicism is when we get stuck in the rut of history, when there is no real clarity on how one 'goes beyond this [the descriptive task] to enter into the full theological dimension. ${ }^{215}$ And yet, in common with many ideological fallacies, we are blinded by our assumption that the difficulty lies in translating 'what it meant' into 'what it means', whereas in truth the problem lies less in this point of crossover, and far more in the presumed objectivity of the descriptive task. For, as Childs and others point out, how we decide to read the Bible determines in a large measure what we get out of it.216 Despite the protestations of New Testament scholars that reading the New Testament texts as historical texts is consensual and neutral,217 it will not drown out the nagging questions: why not read the New Testament toxts as canonically shaped literature or as religious literature which attests to revelation, or texts which witness to the Word of God lying beyond them, a summons which requires our attention? Historical critics may think that by reading the New Testament texts as sources they are standing on cool, objective, neutral ground on which everybody can stand, but there is much truth in Childs' comment 'that the fundamental crror lies in the starting point. 218

For any theological exegesis the starting point must be that in reading 1 Thessalonians we are reading the words of an apostle and witness, one urging ts to look towards that to which he is gesturing. ${ }^{219}$ Paul's words are those of a witness

\footnotetext{
2.12 Childs, 1964, 440-2.

${ }^{213}$ Childs, 1964, 443.

${ }^{214}$ Childs, 1964, 444.

215 Childs, $1964,437$.

216 Childs, 1964, 437.

${ }^{21}$ ' e.g. Raistnen, 1990.

${ }^{218}$ Childs, 1964, 437.

219 As we have consistently seen, this is an important Barthian theme. Far Barth's maturest articulation of the theology of 'witness' see Barth, 1963, 26-36.
} 
willing us to look fowards the reality indicated by his words. As an apostle and witness Paul is constantly pointing beyond and away from himself. His words are best read not as bound within their historical context of production, but as constantly extending beyond their context of production, because Paul's words are the words of an apostle aware that God in Christ's revelation is the ultimate atthority. It is this apostolic sensilivity, letting the Something else be the authority, itself and by its own agency ${ }^{\prime}$,20 which is preciscly at work in 1 Thessalonians $2: 1-12$, and throughout the letter.

As part of this emerging apostolic self-understanding, Paul's courage in the face of great opposition is courage 'in our God' (2:2). Entrusted by God with the gospel, Paul's words are not directed towards the pleasing of humanity, but God (2:4). Paul's very behaviour and delivery of the gospel is one witnessed to by God himself $(2: 5,10)$. In short, what Paul is recounting in 1 Thessalonians $2: 1-13$ is the conduct of an 'apostle of Christ' (2:7), as one set aside by God to witness to God's revelation. As an apostie, Pat1 is always acutely aware of the need to point away from himself and direct attention to the real salvific force at work, 'God's word which is also at work in you believers.' (2:13, emphasis added).

It is perhaps typical that much of the debate surrounding 1 Thessalonians 2:1 - 12 has been concemed with its origins and purpose, rather than its actual content. Such readings are remarkably unfaithful to Paul as wimess and apostle, paying more attention to why Pat1 says what he does, rather than to what Paul is actually saying. Looking for the historically conditioned purpose of texts historical critics miss the witness of the Scriptural text, the ultimate reality or substance towards which the text's author, as witness, is pointing and willing to to encounter. The historicalcritical debate instead chases around those who see the original purpose of these verses as parenetic, and those who see them as apologetic in purpose. ${ }^{221}$

Jeffrey A.D. Weima's article, 'An Apology for the Apologetic function of 1 Thessalonians 2:1-12', is a recent reassertion of this tendency. For those who argue that in 1 Thessalonians 2:1-12 Paul was defending himself against opponents the possible list seems endless: Judaizers, Gnostics, Spiritual Enthusiasts, or

${ }^{20} \mathrm{CDI} / 1,126$. 
Millenarianists from within the church, or indeed non-believing Jews from outwith the church in Thessalonica:2z2 Weima interprets every word and phrase of Paul's as not pointing beyond itself to a world unfolding in front of the text, but rather pointing to some situation that may or may not lie behind the text. Weima's argument thus distorts the full (and most obvious) narrative effect of the pericope, atomising the text from ils ultmate reference, allowing him to posit what he confesses are only 'probable' backgrourds.,223 'l'here is no hint of reading the text just as il stands. Weima assumes that there is an innate transparency to the text, allowing him to advance his real interest - the text's background. For Weima it is idcntifiable historical events which the text ultimalely conveys, not the witness of Paul the apostle.

Having argued that Paul's intention in 1 Thessalonians 2:1-12 is apologetic, and thus reactive, the cast is sct for how Weima reads the verses. For Weima's argtument to sustain itself, he can only mirror read the text, for his argtwont will look all the stronger the more enthusiastically he mirror reads the text. We have here, then, a good example of a closcd methodology, where Weima, by his argument that freezes the language into its original context of production, is predisposed to reading the language as a mirror reflective of 'a historical reality.'224 Correspondingly, Weima argues that antithetical statements can be mixror-read to conclude 'that the attacks against Paul focused on his integrity.'225 Paul's opponents are the compatriots mentioned in 2:14, aggrieved at the Thesssalonians' anti-social conversion from idolatry to Christianity.

The deficiency in Weima's reading of 1 thessalonians lies in his reading of it as a sontre, and not as witness. This results in the irony that in the very verses where Paul is most keen to articulate his apostolic wilness, that there is Something else at work in him, Weima mines these verses for possible histurical contexts. Weima's reading is purely illustrative of a wider malaise that reads the referent of the text as its historical background, and so consistently misreads that to which the text is

\footnotetext{
${ }^{221}$ For a helpfil summary of the arguments, on either side, see, Still, 1999, 137-49.

${ }^{222}$ See Weima, 1997, 73-4.

22.5 Weima, 1997, 84.

224 Weima, 1997, 85.

${ }^{225}$ Weima, 1997, 96.
} 
ultimately witriessing.

Weima's assumption is that the neaning of 1 Thessalonians is what lics 'behind' it. 'Theologically this is deficient because the text's revelatory quality is found not behind, but in the witness of the text itself, and thus a close attentiveness to the text is required at all times. This is what Barth was alluding to when he wrote,

'The prophetic-apostolic witness is the form in which the Bible mediates revelation and in this respect it is the Word of God itself. One cannot separate the revelation from this witness as something that in itself stands behind it, something in itsclf to be observed....Revelation is or rather happens for us in the Scriptures; it happens, there is no way to avoid this, in the biblical texts, in the words and sentences, in that which the prophets and apostles wanted to say and have said as their witnesses....the lexts do not concern us as sources but as a vitness. And the witness is not to be looked for in some fact behind the soluces but within the texts. ${ }^{226}$

Weima misreads the text of 1 Thessalonians, and spectacularly misses its apostolic witness, because for him the res, that which the text is really speaking about, is its historical situation. In Barth's language, Wcima leaps out of the circularity between the texts and their qualily of witness, and so finds something quite alion from what Patl is really communicating.227 If Weima had displayed as much preoccipation with the text and the subject matter which Paul is witnessing to through the form of the text, as he had done with the text's background, he would have discerned the commuricative will of 1 Thessalonians 2:1-12, the miracie of the 'Word within the words. ${ }^{2} 28$

\footnotetext{
${ }^{226}$ Barth, 'Das Schriftprinzip der reformierten Kirche' in Zwischent den Zeiten 3 (1925), pp. 516-7. Cited and translated in Burnett, 2001, 233 (emphasis original).

227? Barth, 1991, 215-6.

${ }^{228}$ Barth, 1933a, 9 (preface to the $2^{\text {nd }}$ edition of Der Kömerbrief).
} 


\title{
(4) Conclusion
}

The assumption that the most faithful reading of Scripture will be the one most disengaged from the Bible's central message needs itself to be exposed for what it is - an untecognised bias, the lingering embers of positivist modemity. Theologically, it is quite justified to decide against siding with the assumptions of the modern reader, in favour of the Biblical author. ${ }^{229}$ Just as Paul was not transfixed by his context of deliverance, but by the subject matter of which he is apostolic witness, so too we must resolve to be gripped by that which. Paul was gripped by, if we want to interpret Paul's words with a sense of rigour and attention. In contrast to all the historical critics we have been reading, our movement throughout this thesis will not be from the text back to its historical context, but from the text forward into its history of reading in the church, and forward into a sympathelic reading alongside its stbject matter. It is this forvard expansion in to the text's fecundity, an eagerness to grapple with the text's uttimale significance, that will be as much present in our reading, as it was in Barth's (in)famous declaration that,

\begin{abstract}
'As one who would understand, I must press forward to the point where insofar as possible I confront the riddle of the stbject matter and no longer merely the riddle of the document as such, until I can almost forget that I am not the author, until I have almost understood him so well that I let him speak in my name, and can myself speak in his name. ${ }^{\prime 230}$
\end{abstract}

This declaration, read correctly, is not a call for attention to 'authorial intention'. Paying attention to the apostle Paul as an authority means paying attention to that to which his words witness. It is this subject matter - the Word in the words, God's will in the feebleness of human words - which bears the ultimate authority, and not oux reconstructed authorial intention. The challenge here is to release our models of authority-in reconstructions of Paul's 'intention' - and dare lo confront the ullimate authority within the text, the subject matter. Confronting the subject matter, accompanying this struggle with a ceaseless attention to the text itself, we will

\footnotetext{
${ }^{229}$ A similar point is made by Barth in Preface Draft $1 \mathrm{~A}$ to the First Edition of his Der Römerbrief. Translated in Burnett, 2001, 281.

${ }^{230}$ Barth, 1933a, 8 (preface to the $2^{\text {nll }}$ edition of Der Römerbrief, emphasis addcd).
} 
discipline uuselves to pass from any interest in Paul as author to that which he was transfixed by. Only from this perspeclive, as the subject matter takes over, will any hankerings after authorial intention dissolve.

From our critiques of historical-criticism, which have been interwoven with our positive proposals with where the meaning of the text is to be found, the rest of the thesis flows successively.

Initially, it is worth reminding ourselves of the emphasis that wc have consistently put on the text itself. Consequently the rest of the thesis will demonstrate a relentless fidelity and reference to the text of 1 Thessalonians.

In Part $\mathrm{II}_{x}$ true to our stated interest in the voices of tradition through which this text has been interpreted, we shall examine the readings of 1 Thessalonians in the hands of 'lhomas Aquinas (1225-1274) and John Calvin (1509-64). The two chapters of Part II will endeavour to be examinations of the readings of the text. We will look closely at both Thomas' and Calvin's reading, namely how they do the business of inlerpretation, and whether there is anything we can learn from their hermeneutics in light of our criticisms of prevailing historical-critical tendencies. Sccondly, we will look closely at their reading of the text, examining what both. Thomas and Calvin say the text is saying and establishing what we have learnt from their commentaries. Reading these neglected commentaries, we shall thus be pointed afresh to the witness of 1 Thessalonians.

Allowing the witness of the text to emerge slowly through cur study of Thomas' and Calvin's commentaries on the text, and methodologically adopting some of their pre-modern methods of exegesis, we shall turn in Part III to our own exploration of the text's depth. Exploring the text in conversation with an eclectic range of voices, we shall endeavour to show in exegetical practice the infinite depth of 1 Thessalonians' ultimate content. 


\section{Part II}

\section{An exploration of some pre-modern readings of 1 Thessalonians}




\section{Chapter Two: Thomas Aquinas and 1 Thessalonians}

\section{Introduction}

Thomas Aquinas (1224/5-1275) is too rarely revered as a Scriptural theologian.1 The theologian for whom sacred revelation was directly equivalent to Scripture ('sacra Scriptara seu doctrina ${ }^{2}$ ) doubtless would have approved of the symbolism inplicit in the Council of Trent's decision to place his Summa Theologiae aside the altar Bible throughout their deliberations. For Thomas, knowledge and understanding of Scripture were co-dependent on the scientia that is sacra doctrina. Examination of Thomas' exegesis therefore demands an awareness of the reciprocity between his expositional studies and his more 'systematic' works." Thomas would not anderstand, nor probably appreciate, our study of 'systematic theology' as distinct from 'Biblical studies'. Study of Thomas' exegetical method and contribution must respect his conviction: that theology, as the supreme science, is the most unified of studies working from indemonstrable first principles to a deeper knowledge of i.tself. 4

Thomas' teaching carecr began at the University of Paris in 1251/2 as a baccalaureus bibicus where, as a cursor biblicus, he lectured on the entirety of Scripture. ${ }^{5}$ In 1254 Aquinas was elevated to the post of baccalaurets Sententiartu, obliging him to comment on the Sentences of Peter Lombard (c.1095-1160). By 1256 Aquinas had graduated to the position of Master in theology (magister in sacru pagina), which for the next three years obliged him to lecture on the Bible daily, to conduct public

\footnotetext{
' Significant studies have sought to reverse the neglect of 'Thomas' exegetical legacy: Baglow, 2002; Valkenberg, 2000; Rogers, 1995.

${ }^{2} S T$ la q.1. a. 2 ad.2. $\Lambda$ cursory glance at the frequent citition of Biblical references in the sed contro sections of the Summa Theologiae articles impresses apon the reader the authority Thomas invests in Scripture. Sce Boyle, J.F., 1995, 102. Note however that Thomas is not shy of drawing in the interpretation of the church (ST 2a2ae q.1 a.8 s.c.) or of Fathers like. Augustine (ST la q.1 a.2 s.c.) as an authority.

${ }^{3}$ So Torrell, 1996, 55, it is imperative to read and use in a much deeper fashion these biblical commentaries in parallel with the grcat systematic works.' So also Rogers, 1995, 9-10; McGuckin, T., 1993, 200; Vass, [962, 30; Sheets, 1961, 170-1.

${ }_{5}^{4}$ ST 1a q. 1 a.7 re; 1 a2ae q.66 a.5 ad.4; 2 a2ae q.171 a.4 re.

${ }^{5}$ Weisheipl, 1974a, 72, holds that Thomas was never a cursor biblicus at Paris. Instend Weisheipl, 1974a, 67f, argues that Thomas lectured on Lombard's Sentences' between 1252-6. Froehlich, 1998, 856 , argues that it was at Cologne that Thomas was at cursor Biblicus, and at Paris began as a baccalaureus sententiartm.
} 
classroom discussions (qutrestiones disputatne), and to preach semons to clergy and laity. Thus, the three functions of the magister were legere, disputare, and pradicare? Between 1259 and 1268 Thomas was heavily involved in teaching Scripture and preaching in Italy, 8 before returning to Paris University in 1269 for another three years. While Thomas is most famous for his two great works, the Sumnu Contrit Gentiles and the Summa Theologiae, and for his commentaries on Aristotle, his formative leaching was actually composed of commenting and lecturing on Scripture. It is worth bearing in mind the implications of the academic hierarchy Thomas ascended so quickly; the highest task for any medieval University teacher was teaching Scripture.

Given Thomas' context this emphasis should come as no real surprise. Despite our propensily to view scholasticism as indicative of a period of abstraction and philosophical indulgence, Thomas' context was a time of evangelical revival, a time when the basic text for the masters' classes could have been nothing but the Bible.10 This revival was embodied by Thomas' own controversial decision to join the newly established Dominican Order (1216), ax order that practised evangelical mendicancy and preaching, ${ }^{, 13}$

${ }^{6}$ Persson, 1970,6.

${ }^{7}$ Gilson, 1955, 246-50. For the importance of preaching to Thomas' vocation as a Dominican theologian sec Torrell, 1996, 69-74; Valkenberg, 1991; for its popularity see Tugwell, 1988b, 259. For Thomas' reference to these three functions of the Master, see his Inaugural Lecture translated in Tugwell, 1988a, 355-60 (358).

${ }^{8}$ Johnson, J.F., 1984, 82.

${ }^{9}$ Tugwell, I988b, 245.

${ }^{10}$ For this evangelical revival see Henly, 2003, 24-33; Pesch, 1974, 585-8; Persson, 1970, 4-6; Chenu, 1964, 44-50, 234-42; Snalley, 1952.

"Hence, their epithet, 'Order of Preachers'. Thomas brings up the theme of preaching freguently in his Thessalonians Lectura. See Lectio Thessalonicenses V.II.134; Duffy, 1969, 52, where preachers are described as 'prophels'. This is especially interesting given Thomas' thoughts on the nature of prophets and prophecy. For Thomas prophecy is a 'gift of grace (which) raises man to something which is above human nature' (ST' 2a2ne q.173 a.2 ad.3). See also Lectio I.I. 19; II.I.28; II.IT.40, 53. The emphasis upon the importance of preaching is particular to Thomas' Bjblical commentaries: see Baglow, 2002, 242-3. The Dominican emphasis on radical mendicancy proved unsettling with certain sections of hoth the laity and clergy. Thomas' counter-cultural decision to join the Dominican Order was very far from the religious life his family had planned for him, and they imprisoned him for a year to test his resolve. See Healy, 2003, 24-33, for the opposition the Dominicans provoked, and Thomas' defence of the Order. In the course of this study we will be reading from both the critical edition of the text, as found in the Marielti edition of 1953 (itself far from perfect - see Weisheipl, 1974a, 247), and Michael Duffy's 1969 translation of the 'l'hessalonians Lectura in the 'Aquinas Scripture Series'. Citations will take the form of Lectio chapter number; lecture number; lecture division, followed by references to the translation. 
Aquinas was a prolific Scriptural commentator. There are extant commentaries on Psalms 1-54, Job, Isaiah, Jeremiah, Lamentations in the Old Testament; and in the New Testament on Matthew, John, Romans, 1 and 2 Corinthians, Galatians, Ephesians, Philippians, Colossians, 1 and 2 Thessalonians, 1 and 2 Timothy, Titus, Philemon, and Hebrews. ${ }^{12}$ As well as these commentaries there is the impressive Catena Aurea ('Golden Chain'), written between 1262/3-1267. This is a commentary on all four Gospels by means of a skilfully woven sequence of writings taken from the Fathers of the East and West. ${ }^{13}$

Thomas' commentaries fall into two groups: reportationes and ordinationes (also known as expositiones). A reportntio represents the notes taken down of a lecture on Scripture as it was actually delivered by Thomas. An ordinatio, on the other hand, represents something much more polished, and was always written or, at the very least, dictated by the author himself.14

The commentary on 1 Thessalonians lies within the group of commentaries formed by Reginald of Piperno's reportationes on the lectures of Thomas. Mandonnet (who has been enormously influential), ${ }^{15}$ sought to tie down Thomas' commentaries to specific academic years, and divided Thomas teaching on Paul into two distinct periods: Italy between 1259-65 and Naples between October 1272 and December 1273,16 the second round of teaching motivated by a desire to improve upon the first attempt. The extant commentaries on Job, Isaiah, Jeremiah, Lamentations, Romans and as far as 1 Corinthians 7:9 represent these improved ordinationes. It would appear that the section from 1 Corinthians $7: 10$ through to chapter 10 represents an insertion from the postilla of Peter of Tarentaise. ${ }^{17}$ Thomas' death interrupted any further progress on the remaining commentaries, and so our immediate concern is that Thomas' commentary on 1 Thessalonians remains as a reportatio.

\footnotetext{
12 Traditional assignations to Aquinas of a commentary on the Song of Songs lack documentary evidence, and consequently, are deemed spurious.

13 Torrell, 1996, 136-40.

It Weisheipl, $1974 \mathrm{a}, 117$.

15 Mandonnct, $\mathrm{P}$. 'Chronotogic des cerits scripturaires de s. Thomas d'Aquin'. Revue Thomiste 33 (1928), pp. 222-45. For criticisms of Mandonnet's thesis see Torrell, 1996, 251-2.

i6 See Baglow, 2002 , I 15.

17 Eschumam, 1957, 399.
} 
Perhaps the wisest course is to echo Jean-Pierre Torrell's tentativeness and opt for Thomas' teaching in Orvieto, Rome between $1265-8$ as the context for his 1 Thessalonians lectures. ${ }^{18}$ If Thomas followed the order of the Vulgate we can assume that his lectures on 1 Thessalonians would be a little over halfway through his coturse.19 Thomas' lectures on 1 Thessalonians are therefore posterior to his Simmit Contra Gentiles (1259-64), yet very close in time (if not concurrent) with the composition of the Summa Theologiae (1266-73), both theological resources we will draw upon.

Taking our cue from the concluding remarks in Part I, our study of Thomas' commentary will be concerned, first of all, with Thomas' reading, how he does the business of interpretation. We will examine his use of auctoritates in commenting on the text (\$ 1.1). We will pay especially close attention to the way in which, throughout his excgesis, Thomas nests his comments within Biblical citations. We will also see how he reads and dcploys the Patristic inheritance, engaging with one instance of Thomas' use of the interpretative tradition. In section 1.2 we will examine Thomas' disciplined, Aristotelian reading of the text. These two sections - examining the influence of the canon, the Fathers, and Aristotle - will equip us in examining Thomas' profoundly theological exegesis of I lhessalonians 4:13-18 (§ 2). We shall conclude (\$ 3) with some reflections as to Thomas' theological and exegetical contribution to our reading of 1 Thessalonians in Part III.

\footnotetext{
${ }^{18}$ Torrell, 1996, 255. So too Valkenberg, 2000, 175. It might be legitimate to query the reliability of the commentury, knowing that it is nut from the hand of Thomas himself, but that of a secretary (for the Pauline commentaries, one Reginald of Piperno). Just how safe is it to build up an argument upon the foundations of a text written by a scribe and not the author himself? There are undoubtedly grood grounds to retain confidence in the reliability of the text. Mandonnet's comparison of Thomas' reportationes and expositiones uncovered little difference in style (cited by McGuckin, T., 1993, 203), indicating the care with which 'l'homas' lectures were transcribed. As Baglow notes, were we to make Thornas' own hand 'lle criterion for reliability, many if not most of Thomas' work would have to be set aside.' (Baglow, 2002, 120) Certainly many medieval texts which scholars work from are the fruits of lecture transcriptions, and there is evidence from Bernard Gui that Thomas had time to check the transcriptions of his lectures (Lamb, 1966, 23). Stories of Thomas dictating to three sceretaries simultaneously are indicative of a famed energy that could only have been reatised with the aid of secreterial assistance. Faced with a text which bears all the hallmarks of Thomistic exegesis, and unwilling to relinquish much of 'Thomas' other work, it seens wisest to affirm the authenticity of our commentary, despite it being written by a secretary.

${ }^{19} \mathrm{cf}$. Lamb, $1966,28$.
} 


\section{The hermeneutical principles of Thomas' 1 Thessalonians Lectura}

\subsection{Thomas and auctoritates}

\section{(a) Thomas and the canon}

The misconception that Thomas was steeped in a dry and introspective scholasticism has long given way to the realisation that, for somcbody who at one time was lecturing on Scripture up to four times a week, he is rightly recalled as a biblical theologian. 20

The manner in which Thomas reads Scripture throughout his Thessalonians Lectura is foreshadowed in the Prologue. ${ }^{21}$ Thomas' begins by citing Genesis 7:17, 'The waters increased and bore up the ark and it rose above the earth', as words 'appropriate' (competent) to the subject matter of 1 Thessalonians. ${ }^{22}$ Thomas clearly gives the 'ark' a spiritual interpretation, a meaning guided by the providence of God who, 'has the power, not only of adapting words to convey meanings (which men can also do), but also of adapting things (res) themselves. ${ }^{\prime 23}$ For where the literal sense of this Genesis passage could not refer to the church, a spiritual interpretation allowing God's dircation of events permits the ark to symbolise the church (presaged by 1 Peter 3:20), for in both, 'only the elect will be saved' (soli electi salvabuntur). ${ }^{24}$ In this spiritual interpretation, the 'waters' of Genesis 7:17 'signify' (significantur) the tribulations afflicting the church. First because, quoting from Matthew 7:25, waters have a tendency to 'strike like tribulations'; second because, turning this time to Fcclesiasticus 3:30, water extinguishes fire, and tribulations likewise can quell the fiery 'force of desires' which threaten the church's good order; and third because, this time quoting from Lamenfations 3:54 and Jonah 2:6, water threatens to inundate the church but the church is not yet overcome by flooding. The Thessalonian church is signified by the ark, because just as the ark rose up on the deadly waters of the flood, so too the Thessalonian church in its tribulations is assured not of its

\footnotetext{
${ }^{20}$ Valkenberg, 2000; Froehlich, 1998; Chenu, 1964, 259-60.

21 cf. Black, 1986, 682-3.

22 Prologis; Duffy, 1969, 3.

${ }^{23}$ ST la q.1 a.10 re. See Copeland, 1493, 13; Rogers, 1996, 66, 80.

${ }^{24}$ Prologus; Duffy, 1969, 3.
} 
destruction, but its uplifting. Much of this assurance lies in God's providential direction of events. ${ }^{25}$

Thomas' prologue is interesting for the way it weaves the literil referents of diverse Scriptural passages, into a coherent, spiritual truth (that in times of suffering the Church is not destroyed but uplifted'). ${ }^{26}$ Moreover, not being restricted to literal meanings of texts, Aquinas reads Genesis 7:17 more expansively than the human authors could have intended. This is because God, as principal author of Scripture has the capacity of 'adapting things [in our case, the ark] themselves', and so 'the things meant by the words also themselves mean something. ${ }^{27}$

That Thomas should rely so heavily on such an intratextutal reading of the Bible is not surprising. If, for Thomas, God is the primary author and mover of Scripture then it will be a text constantly explaining itself through itself. What is vague or obscure in one part will be explained by another part: ${ }^{28}$ Thomas' keenness for extracting the meaning of 'the Bible by the Bible' continues throughout his lectures. ${ }^{29}$ The following two tables, detailing the extent of Thomas' Scriptural citations, go some way to disclose Thomas' remarkable Scriptural literacy, ${ }^{30}$ In Table 1 the citations from the Old and New Testaments are ranked separately. Table 2 ranks the Old and New Testament citations together, thus depicting the whole canonical scene.

\footnotetext{
${ }^{25} \mathrm{cf}$, the same spirittual interpretation of the ark in $S T$ 2a2ae q.173, a.3 re, where the ark is 'ordained to be prophetically significant'.

${ }^{26}$ Prologus; Duffy, 1969, 3.

${ }^{27}$ ST la q.1 a. 10 te.

${ }^{28}$ ST la.q.1 a.9 ad. 2.

${ }^{29}$ Mc Guckin, '1', , 1993, 205.

${ }^{30}$ These tables follow a similar method adapted by Baglow, 2002 in his study of Thomas' Ephesians lectures.
} 
Table 1 - New Testament and OId Testament citations

\section{i) NT citations}

Romans 26

1 Corinthians 24

Matthew 20

Luke 19

Acts 16

Jolun 15

2 Corinthians 11

Philippians 11

Hebrews 10

Galatians 9

1 Peter 8

Ephesians 7

James 6

1 Timothy 5

Revelation 5

2 Thessalonians 4

Colossians 3

2 Timothy 3

Mark 2

2 Peter 2

1 John 2

Titus 1

Jhilemon 1

3 John 1 ii) O' and Deutero-canonical citations

Psalms 23

Isaiah 18

Proverbs 17

Sirach (Ecclesiasticus) $I^{\text {ji }}$

Wisdom of Solomon 8

Job 7

Genesis 6

Jeremiah 5

Ezekiel 5

Leviticus 4

Ecclesiastes 3

Song of Songs 3

Numbers 2

Dezileronnmy 2

Exodus 1

1 Samuel 1

2 Samuel 1

1 Kings 1

2 Kings 1

1 Chronicles 1

Lamentations 1

I Iosea 1

Jocl 1

Amos 1

Jonah 1

Micah 1

Zechariah 1

Malachi 1

Tobil 1 


\begin{tabular}{|c|c|c|}
\hline 1) Romans & 26 & 31) Numbers \\
\hline 2) 1 Corinthians & 24 & 32) Deuteronony \\
\hline 3) Psalms & 23 & 33) Mark \\
\hline 4) Matthew & 20 & 34) 2 Peter \\
\hline 5) Luke & 19 & 35) 1 John \\
\hline 6) Isaiah & 18 & 36) Exodus \\
\hline 7) Proverbs & 17 & 37) 1 Samuel \\
\hline 8) Acts & 16 & 38) 2 Samuel \\
\hline 9) John & 15 & 39) 1 Kings \\
\hline 10) Sirach & 11 & 40) 2 Kings \\
\hline 11) 2 Corinthians & 11 & 41) 1 Chronicles \\
\hline 12) Philippians & 11 & 42) I amentations \\
\hline 13) Hebrews & 10 & 43) Hosea \\
\hline 14) Galatians & 9 & 44) Joel \\
\hline 15) Wisdom & 8 & 45) Amos \\
\hline 16) 1 Peter & 8 & 46) Jonah \\
\hline 17) Job & 7 & 47) Micah \\
\hline 18) Ephesians & 7 & 48) Zecharial \\
\hline 19) Genesis & 6 & 49) Malachi \\
\hline 20) James & 6 & 50) Tobit \\
\hline 21) Jeremiah & 5 & 51) Titus \\
\hline 22) Ezekiel & 5 & 52) Philemon \\
\hline 23) 1 Timothy & 5 & 53) $3 \mathrm{John}$ \\
\hline 24) Revelation & 5 & \\
\hline 25) Leviticus & 4 & \\
\hline 26) 2 Thessalonians & 4 & \\
\hline 27) Ecclesiastes & 3 & \\
\hline 28) Song of Songs & 3 & \\
\hline 29) Colossians & 3 & \\
\hline 30) 2 Timothy & 3 & \\
\hline
\end{tabular}

${ }^{31}$ Thomas was aware of the marginal status the book had within the Christian canon $-\$ T$ la q.89 a.8 ad.2. For Thomas' canon see Pope, 1924, 10-13. 
Of these 340 Scriptural citations the vast majority are from the New Testament 211 or $62 \%$ of the total), with $129(38 \%)$ from the Old Testament.32 The majority of the New Testament citations are from Paul's epistles (including the Pastorals and Hebrews) - 115 out of 211 total New Testament citations. When we add to this figure citations from the other non-narrative texts (the Catholic Epistles) the figure rises to 134. The Gospels, Revelation, and Acts (what we may call here 'narrative' texts) account only for $77(36 \%)$ of the total New Testament citations.

That $34 \%$ of the total Scriptural citations are drawn from the Pauline literature is not surprising given Thomas' stated high regard for his theological contribution. ${ }^{33}$ Neither is it surprising that Romans is the most cited of the Scriptural texts - the epistle of grace is for Thomas an inlerpretative and explicative key. ${ }^{3:}$ Moreover, that $39 \%$ of the Scriptural citations (and $64 \%$ of the New Testament citations) come from the non-narrative sections of the New Testament supports those who claim that Thomas prefers to work, with non-narrative texts that 'mediate their messages conceptually and directly.'35

When it comes to the citation of the Old Testament, 'Thomas's reliance upon the Psalms is often noted, and his Lectura on 1 Thessalonians are no exception. Psalms account for $18 \%$ of the total Old Testament citations. Thomas's knowledge of and passion for the Psalms is undoubtedly related to his daily liturgical use of them in worship.36 Certainly, Thomas reserved a consistently high regard for the Psalms, reading their subject matter as Christ and the church. ${ }^{37}$ Isaial and the Wisdom literature also emerge as heavily cited books.38

${ }^{32}$ It has been surmised that when quoting Scripture, Thomas was doing so from memory, a skill mastered during his imprisonment at the hands of his family between 1244-6. See Torrell, 1996, 11; Tugwell, 1988b, 205-6; Weisheipl, 1975, 194; Pope, 1924, 9-10.

${ }^{33}$ See Thomas' Prologue to the Pauline commentaties, translated in Torrcll, 1996, 255-6.

${ }^{34}$ In the Prologue to his Pauline commentaries, Thomas spoke of Romans as dealing with Christ's grace 'in itsulf'. See Torrell, 1996, 256.

${ }_{35}^{35}$ Baglow, 2002, 132.

${ }^{36}$ Torrell, 1996, 34.

${ }^{37}$ Psalms, Proemium. See Torrell, 1996, 34 tor a tuanslation, 'Everything that touches on the final goal of the Incarnation is presented in the Psalter with such clarity that we might think that we are reading the Gospel, not a prophet.... The subject matter of this book is Christ and His Church.' See also ST 2a 2ae q.174 a.4 ad.1. This reading of the Old Testament as Christocentric is a distinguishing characteristic of premodern interpretation - alt Scripture speaks of Christ. See Lectio I.I.22, wherc 
Aside from this quantitive analysis of Thomas's use of Scripture it is necessary to pay attention to how he actually worked with Scripture to generate understanding of 1 Thessalonians.

Scripture for Thomas is its own interpreter, ${ }^{39}$ and thus the meaning of a phrase employed by Paul in 1 Thessalonians can be clarified by reference to further texts. But, unlike modern exegesis (and, as we shall see, Calvin) which prefers to explain what Paul says in one text with reference to what he says in another Pauline text, Paul is explained by reference to any part of Scripture. This is perhaps not surprising given that, for Thonas, God was the author of Scripture, and so in inspiring the writers to write tunderslood everything he was doing: radical unity of scriptural truth', 41 a conviction borne from the belief that God was Scripture's principal cause. ${ }^{42}$

There are two obvious ways in which Thomas deploys Scripture in his Thessalonians Lectura.

1) Thomas uses Scripture as an authority to illuminate the reference of 1 Thessalonians. A good example of this deployment is 'Thomas' exposition on 5:5, which talks of the Thessalonians being 'sons of light and sons of the day'. Thomas delves deeper into the meaning of Paul's description of them as 'sons' by tuming to Isaiah $5: 1$, in corroboration of his point that what 'Scripture says', 43 is that 'someone is said to be the son of sometling because he abounds in that thing. ${ }^{41}$ The Vulgate refers here to 'filio olei', that is 'the son of oil'.45 Modern translations render this as 'very fertile' (as with the RSV), but Thomas would appear to read this reference to

Thomas plainly reads Isaiah 30:18 ('Blessed are all those who wait for him') as referring to the coming of Christ, the reference of 1 Thessalonians 1:9-10.

${ }^{38}$ Torrell, 1996, 34, suggests that Wisdom literature was popular at the time because it lent itself easily to moral instruction.

${ }^{39}$ cf. McCsuckin, 'l', 1993, 206.

40 ST 1a q.1 a.10 re, 'auctor autem sacrae Scripturae Deus est qui omni:t simul suo intellectu comprehendit.'

${ }^{41}$ Black, 1986, 688 .

${ }^{42}$ Pope, 1924, 24-27.

43. Lectio V.I.115; Duffy, 1969, 44.

${ }^{44}$ Lectio V.I.1 15; Duffy, 1969, 44.

${ }^{45}$ The full Vulgate verse of Isaiah 5:1 tuns as follows, "cantabo dilecto men canticum patruelis mei vineae suae vinea facta est dilecto meo in cornu filio olei.'

${ }^{46}$ Lectio V.I. 115 ; Dulfy, 1969, 44. 
'son' as a warrant for demonstrating his main point: that sons are those who share and abound in the same thing as the father, in this case the fertility of the land. Turning to Isaiah in order to understand Paul's reference to 'sons', Thomas deploys John $8: 12$ and $12: 36$ to exposit the reference to 'light' as a reference to the 'faith of Christ' (fides Christi). ${ }^{46}$ This extrapolation cnables him to draw an elegant parallel which exposits Paul's reference to 'the day'. Just as out of light comes day, so out of the light that is the faith of Christ (note that for Thomas it is Christ's faith, rather than our faith in Christ which would appear to be operative here) comes the day of 'good works' (bonorum operm). ${ }^{47}$ Appropriately, Thomas inserts Romans 13:12, 'The night is far gone, the day is at hand.' More than being a decorative proof text, Scriphure is itself part of the interpretative sequence.

In Thomas' reflections on 5:5, and other verses, we also get some clues as to how he worked. It has been suggested by Jean-Pierre Torrcll that Thomas worked with an early form of a concordance, 48 and indeed many citalions seem to be selected on account of their word association. ${ }^{49}$ Certainly, in expounding the meaning of the word 'lux' in 5:5 it is not urreasonable to contend that Thomas turned to some form of concordance which directed him to John 8:12, 'Ego sum lux mundi' and John 12:36, 'Credite in lucem'. So too do we see this spiral of word associations in other places of the commentary. In the first Lectio on chapter 1, Thomas turns to 1 Corinthians 15:10, 'Gratia Dei sum id quod stum', when talking about the 'gratia' which Paul asks as a blessing upon the church. It seems quite possible then to agree with Torrell that Thomas worked with some form of concordance.

Another example of Scripture acting as a primary explanatory source in Thomas' exegesis is in his comments on 1 Thessalonians 2:18, "we wanted to come to you $-\mathrm{I}$,

\footnotetext{
${ }^{4 /}$ Lectio V.I.1 15; my translation.

${ }^{48}$ Torrell, 1996, 33-4.

${ }^{49}$ Lectio V.II.139, Dufly, 1969, 54, where Thomas, commenting on Paul's direction to "greet each other with a holy kiss' (5:26), contrasts it unfavourably to the 'passionate' (libidinoso) kiss of the wuman in Ploverbs 7:13, and the 'treacherous' (praditorio) kiss of Judas in Matthew 26:49. Of course it might just be that Thomas knew his Scriptures so well that he could cite these texts from memory, as suggested by Valkenberg, $2000,40$.

${ }_{50}$ Revelation 7:1, 'Four angels standing at the four corners of the earth, holding back the four winds of the earth.'
} 
Paul, again and again - but Satan hindered us.' Thomas turns to Revelation 7:1 in an attempt to understand the nature of the obstacles put in Paul's way.50

2) Second, as a canonical and scholastic theologian, 'Thomas uses Scripture in a secondary mode to prompt its own quaestiones, the responsiones to which prompt new understanding. ${ }^{51}$ Just as Scripture is self-explanatory, so too for Thomas can it act as a source of quaestiones and means for combating error, a profoundly scholastic drive. ${ }^{52}$ The nature of Thomas' canonical tendencies is emphasised by an extended reflection in Lectio I.I.12-13. Thomas considers how Paul's report of his successful preaching is at risk of contradicting what is said elsewhere in Scripture (a frequent concern to medieval exegetes), in this case Ezekiel 3:26, 'And I will make your tongue cleave to the roof of your mouth, so that you shall be dumb.' Extraordinarily (to our modern sensitivities) Thomas suggests that Paul was aware of this contradiction, stating that it was, 'For that purpose', Paul first called to mind with what power he preached to them, and secondly, how they were wilness to these events. 53

This same concern, that Scripture cannot contradict itself and so be shown to be tuntrue in any way, ${ }^{54}$ is evident in Thomas' comments on the ethical advice in 4:11, where Paul ưges the Thessalonians to 'mind your own affairs'. Here, in Lectio IV.1.90 Thomas sets up his own mini scholastic disputation, asking if Paul's advice contradicts what he says in Romans $16: 2$, to 'Help her in whatever she may require from you.' Confirmation that Thomas is constructing his own little disputation comes in the next line, where he signposts his 'Respondeo',55 Thomas' resolution to this apparent tension is somewhat enigmatic,

'I elaborate by pointing out that things occur in a disorderly manner if they are not governed within the limits of reason, for example, when somebody drives himself excessively; they occur in

\footnotetext{
${ }^{51}$ Baglow, 2002, $108-9$.

${ }^{52}$ Pesch, 1974, 588; Chenu, 1964, 86.

53 Lectio I.I.13. Our translation slightly differs from Duffy's who finds the infinitive 'to counter' in the text.

${ }^{54}$ ST 1 a2ale q. 103 a.4 ad.2.

${ }^{55}$ Similar 'mini-disputations' are in Lectio IV.II.98; IV.II. 101; IV.II.102; V.I.108; V.I.111; V.II.128.
} 
an orderly manner if the dictates of reason are observed in

regulating them. ${ }^{\prime \prime}$ s

In these instances Scripture, prompting its own questions of inquiry, is used to delve decper into the meaning of the text.

There is another conclusion to be drawn from Thomas' use of Scripture in his Thessalonians Lectura. Thomas' apparent naïveté in the ways of historical awareness and text critical issues is often remarked upon, 37 though there is evidence that Thomas was not as unsure in the ways of Biblical (or at least textual) criticism as many have thought: ${ }^{58}$ Thomas was certainly no historical-critic (not, of course, that this was something he was consciously opposing). His fervent espousal of gaining meaning from Scripture by citing other parts of Scripture reveals that it was the canonically narrated history, and the canon's organic history within the tradition of the church, which held the interpretative authority. ${ }^{59}$ Thomas' understanding and tolerance of history was not unusual for a medieval theologian: the history worth considering is the history of God's retationship with his created people.60 This is not the endeavour of historicism, the misguided attempt to attempt to find meaning and truth in the reconstruction of what lies 'behind the text'. Instead, Thomas' love of the different texts of Scripture and the different texts of interpretation, reveals a deep fidelity to a conviction that 'Luth does nol descend from the blue; it is achieved in the and through history', ${ }^{61}$ but chiefly through the textuality of Scripture itself.

\footnotetext{
5ectio IV.I.90; Duffy, 1969, 33.

57 Stump, 1994, 186-7; 1993, 256.

${ }^{58}$ See the acidic comments of Pope, 1924, 17, "it would be no less absurd to maintain that he (Thomas) knew no Hebrew. We have got to rid our minds of the notion that knowledgre of Hebrew only came in with the Reformation. ' For 'Thomas' attention to Hebrew and Greek see, respectively, ST 1a q.68 a.4 re; 2 a2ac q.1 a.6 ak.3; Lectio loannis I.IX.197. For those atguing for Thomas's awareness of Scriptural languages and textual criticism see Jordan, 1987; Principe, 1978; Geenan, 1952, 180; Callan, 1947. The extent of 'Thomas' Hebrew and Greck exercises many of Thomas' contemparary students. The appearance of Thomas' scant knowledge of the Biblical languages (so Stump, 1993, 256; DobbsWeinstein, 1989, 106) is not improved given that the preceding decades had seen a resurgence of interest in Greek and Hebrew. Thomas was shy not just of the ancient languages - for all bis years in Paris Thomas never thought it worthwhile to learn French (Weisheipl, 1974a, 128).

${ }^{59}$ Torrell, 1996, 35, hints at the genesis of this idea. For the authority of the church sce Lectio V.II.137; $S T 2$ a2ae q.1 a.7 re; 2 a2 ae q.5 a.3 ad.2.

${ }^{60} \mathrm{cf}$. Moltmann, 1985, 332, "There is for Thomas only one transition which occurs within the history of God with humanity and that is the step from Israel to the Church.' A cursory reading of Thomas thus notices how little regard he has for any linear conception of history. For example, in his exegesis of 1 Thessalonians he notes that Paul is giving advice about how the Thessalonians should behrive in relation to bishops and priests: Lectio V.TL.125.

${ }^{61}$ Maurer, 1979, 33 (emphasis addled).
} 
A short section of 'Thomas' excgesis may help corroborate what we are saying here about Thomas viewing history through the lenses of Scripture. Towrards the end of his Lectura Thomas engages in what, at first reading, looks like speculative mirror. reading of the text. Commenting on 1 Thessalonians 5:27, Thomas says that, 'Paul feared that those in charge of the assembly might suppress it because of some of the things contained in it. ${ }^{62}$ But this is clearly a conjecture drawn from the deep well of Thomas' Scriptural knowledge, the authority behind the claim being Scripture. For Thomas Scripture always explains Scripture, and in this case 1 Thessalonians 5:27 is explained by Proverbs 11:26.

\section{(b) Thomas and the Fathers}

One of the surprising features about Thomas' Lectura is the freedom he evidences from citing copious Patristic references. References to the Fathers, or Peter Lombard's Gloss, ${ }^{63}$ are more notable for their scarcity than their preponderance. In total there are a mere eight direct references to the Fathers. ${ }^{64}$

Part of the reason for Thomas' apparent reticence on this is his context. Unlike later interpreters, in particular the Reformers, Thomas' situation was much less polemical, ${ }^{65}$ and he did not need to establish his continuity with the early church tradition. To be sure, Thomas was of the opinion that those 'who were closer in time to Christ....had a fuller knowledge of the mysteries of faith', 66 but Thomas' credentials, and his church's apostolic continuity were unquestionable, and so this may be one reason why Thomas has the confidence to appeal so rarely to the Fathers as an authority. Nobody aware of 'Thomas' other works could be in any doubt that

\footnotetext{
${ }^{62}$ Ler.tio V.II.139; Duffy, 1969, 54. Lectio II.I.32 is a parallel to this example, where Thomas explains the Bible by the Bible with reference to Isaiah $3: 14$.

62 As Smalley, 1952, 334, notes medieval exegesis understood Scripture and the Gloss to be virtually coinlicrent, 'Scripture, as expounded at Paris, was the text in the light of both patristic and medieval thadition, indissolubly wedded to it in the Gloss.'

${ }^{60}$ Thomas refers to Gregory the Great in the Prologus; Lombard's Gloss, Collectanea in epistolis S. Pauti, (Folio CXCIV) in Lectio Ill.1.62; to Augustine in III.I.64; IV.I.98; V.I.3; to unattributed tradition in IV.II.102; to Jerome in IV.I.85; IV.I.101; to a Gloss which 1 have not yet been able to identify in V.R.130; and to the Lives of the Fathers in V.II.130. There is an indirect (and uncited) reference to John Damascene's Christology in Lectio IV.II.95, discussed below in $\$ 2$.

${ }^{65}$ Notwithstanding, of course, Thomas' membership of the controversial new Dominican order, an order that he freclutently had to defend: Healy, 2003, 28-33.

${ }^{66}$ ST 2a2ae q. 1 a.7 ad.4. See also ST 2a2ae q.174 a.6 re.
} 
for Thomas the authority of the church was coinherent with the authority of Scripture and that Scriplure lived within the discourse of the intexpreting church.6?

Thomas' reference to Augustine in Lectwra V.1.3 affords an opportunity to examine how Thomas deploys the Patristic inheritance. Thomas is vexed by the apparent contradiction between 1 Thessalonians 5:3 and Luke 21:26. The problem is that one text says that the persecutors of the church will think they have 'peace and security' (1 Thess 5:3), whitst another says that in the end times people will faint 'with foar and foreboding' (Lk 21:26). To resolve this problem Thomas appears to draw upon the 36 th chapter of Aligustine's letter to Heschyius.68 Equally vexed by this seeming inconsistency in Scripture's witness Atugustine proposes that the 'peace and security' of 1 Thessalonians 5:3 refers to the evil people, whilst the 'fainting' and 'foreboding' of Luke refers to the plight of the good people (at the hands of the evil in the end times) ${ }^{69}$ In this cilation Augustine thus serves to maintain Scripture's 'harmony of truth'.70

In his attention to the voice of Paul the apostle, the Fathers are guardians of Paul's revelation and are enlisted when they serve to free Paul's voicc from confusion or contradiction. Consequently Thomas turns to the Patristic inheritance to clarify what might seem obscure in 1 Thessalonians or even contraclictory in relation to the rest of the canon. There is no questioning of Scripture's pre-eminence, for it is the 'superior science ${ }^{\prime}{ }^{71}$ and faith rests on the revelation made to the apostles and prophets, not on any doubtful revelation to 'any other teacher' ${ }^{72}$ The combination of the revelation directly mediated to the apostles and the words of Sacred Scripture makes our faith certain. ${ }^{73}$ Nevertheless, the authoritative words of Augustine can be enlisted, insofar as he himself twrns us to hear with clarity the teaching and insight of those who were closest to the brilliance of Christ,

\footnotetext{
${ }^{67} S T$ a a a q. 5 a.3 ad.2. See Jondan, 1987, 456.

68 Aligustine, 'Letter' 199 ', 36.

${ }^{69}$ Thomas touches upon this possible contradiction again in ST (Supplementum) 3a q.73 a.1 ad.1.

${ }^{20}$ Principe, 1978, 115.

${ }^{71}$ ST la q.l a.8 re.

${ }^{72} S T$ la q.l a.8 ad.2.

${ }^{73} S T$ la q.1 17 a.2 ad.2; I a2ae q. 103 a.4 ad.2; 2 a2ae q. 110 a.3 ad.1; q.174 a.6 re.
} 


\begin{abstract}
'Apostle are put first because they had a privileged share in all of Christ's gifts. They possessed a plenitude of grace and wisdom regarding the revelation of divine mysteries... They also possessed an ample ability to speak convincingly in order to proclaim the gospel...Moreover, they also had an exceptional authority and power for looking after the Lord's flock' ${ }^{74}$
\end{abstract}

\title{
1.2. Thomas, Aristotle, and the text of 1 Thessalonians
}

Steeped in Aristotle's thought, Thomas consistently emphasised acquisition of knowledge through sensible forms..$^{75}$ This assertion of knowledge through sensible matter is marked by, at one level, a repudiation of Plato's notion of 'Ideal Forms', and at another level a re-assertion of the composite role of the soul and the body in understanding. One does not have to look hard to see this polemic jutting through the surface of Thomas' 1 Thessalonians commentary. ${ }^{76}$

The exegetical implications of Thomas' enthusiasm for Aristotle are well documented. ${ }^{77}$ For Thomas just as any spiritual meanings in the Biblical text are to be firmly supported by the literal sense of the text, ${ }^{3}$ so too do we only know spiritual realities through sensible matter. Philosophically, Thomas pays close attention to the external, assuming that our knowledge must conform to things themselves. Thomas' concentration on the extemal corresponds to a close attentiveness to the text itself, and its plain, literal sense. It is then quite logical that for Thomas the literal sense of the text acquired a new foundational significance, as that upon which any further meanings should be grounded. ${ }^{79}$

\footnotetext{
${ }^{74}$ Lectio Ephesios IV.IV.211; Lamb, 1966, 163. See ulso ST la2ae q.106 a.4 ad.2; 2a2ae q.1 a.7 ad.1 and ad.4; Lectio loantis I.VIII.183; II.D.383; IV.IV.651. So also McNally, 1961, 451; Elders, 1990, 132.

${ }_{75}^{75}$ ST la q. 1 a.9 re; la q.84 a.3 re; q.86 a.6 re; 2 a2ae q. 175 a.5 re; 2 a2ae q. 178 a.1 re; 3 a q.30 a.3 ad.2.

${ }^{76}$ Lectio I.I.21 (for which see Henle, 1956, 48-9); IV.II.93; V.II.137. Cf. ST la q. 1 a.6 ad.2.

${ }^{77}$ 'orrance, 1962; Smalley, 1952, 292-308, are the most reliable.

${ }_{79}^{78}$ ST la q.1 a. 10 ad.1.

${ }^{79}$ ST 1a q. 1 a.10 ad.2; 3a q.5 a.3 re. Secondary literature on 'Thonas' understanding of the literal sense proliferates: Loughlin, 1995; Copeland, 1993; Johnson, M.F., 1992; Kennedy, 1985.
} 
Two aspects of Thomas' exegesis of 1 Thessalonians speak loudly of Aristotle's influence. The first aspect of Thomas' hermeneutics which affords an examination of Aristotle's influence is his relentless division and stubdivision of the text. The second aspect - the deployment of Aristotelian causality - is directly related to Thomas' theological exegesis of 1 Thessalonians 4:13-18, and will be left to closer examination in section 2 .

Beginning with Thomas' division of the text is apt for Thomas lectures would themselves have begun with a reading aloud of the text, ${ }^{80}$ after which he would have broken the text up into appropriate rhetorical structures. 'Thomas divides and subdivides the text of 1 Thessalonians throughout his Lectura. At this stage let us therefore focus on how Thomas divides up, and so understands, the order of 1 Thessalonians 4:13-18, an analysis that we will utilise in the following section (\$2). Table 3, under the rubric of Thomas' own stated theme for the verses, sets out how Thomas divides Paul's text (with the canonical references Thomas appeals to iunderneath).

\footnotetext{
80 A matter of pragmatics given the cxpense and shortage of printed Bibles. Sce Acrsen, 1993, 15; Weisheipl, 1974a, 116; Gilson, 1955, 247.
} 
Table 3: Thomes's structuring of 1 Thessalonians 4:13-18

Paul's argument: 'he urges them to lessen their inordinate sorrow.'

1) 4:13: 'he provides a warning'

Sirach 41:1; 1 Sam 15:32; Rom 6:23; Ecclesiastes 7:2; Sirach 22:11; Phil 3:20; In 11:11; Ps 40:9;

Song of Songs 5:2; 1 Cor 15:52

2) 4:14f: 'he provides a reason for the warning'

2.1) 4:14: 'he establishes the resurrection'

1 Cor 15:12; Zech 1.4:5; Isaiali 3:14

2.2) 4:15: 'he rules out the faint suspicion of a delay'

2 Thess $2: 2 ; 1$ Cor $15: 52$

2.3) 4:16: 'he outlines the order of resurrection'

2.3.1) 4:16a: 'he discusses the cause(s) of the resurrection'

1) 'the trumpet of God' = ' the divine power'

Wisdom 5:20

2) 'the Lord himself' = 'the power of the humanity of Christ'

Acts 1:11; Phil 2:8; Lk 21:27; Jn 5:28

3) 'swith the archangel's call' = 'a ministering cause'

Rev 12; Isa 9:6

2.3.2) 4:16b-17: 'he presents its order and manner'

L) 4:16b: 'he treats the resurrection of the dead'

2) 4:17a: 'he considers the meeting of the living with Christ'

1 Cor 15:51; 1 Cor 15:22; Rom 5:12; 1 Cor 15:52; Mt 24:28; Phil 3; Acts

1:9; 1:1 1 ; $\mathrm{Kgs} 8: 12$; Mt 25:6

3) 4:17b: 'he refers to the happiness of the saints with Christ' Jn 14:3; Phil 1:23

2.3.3) 4:18: the ends with a consideration of their mutual consolation' Is $40:$ :

Uncovering the shape of the text in this manner should not be read as Thomas attempt to recover the mind 'behind' the text. Rather, it is expressive of a deep fidelity to the text and its movements, confident that an Aristotelian understanding of its shape and contours is an understanding of the sacra doctrina revealed by the text. Thomas is fascinated for the 'reasons' the apostle says what he says, ${ }^{81}$ but these 'reasons' are found by sticking closely to the argument of the text itself. ${ }^{82}$ lt is of note, as close reading of the Lectura reveals, that the text divisions are formed quite independently from the canonical conversation that follows the divisions. Thomas' chicf conviction, of which the divisions speak, is that the text is to be revered as a carefully crafted web with the God of order as its primary author: 83

Thomas' incessant desire to break up 1 Thessalonians in the task of understanding its meaning in relation to the whole of the letter and the whole of Scripture can be more

\footnotetext{
"Lectio IV.1.91; Duffy: 1969, 33.

${ }^{22}$ See, for example, Lectio III.I.72; Duffy, 1969, 27.
} 
exactly traced to his Aristotclian background in two ways. ${ }^{84}$ The first is relatively undisputed, the second, while linked to the first, is more complex.

First, Thomas ains to understund the text as Aristotle said an artisan should understand his creation. Working from the text of Scripture as his 'first principle' Thomas hopes to undersland the conlours of the text by a process of composing and dividing, an intellectual mode of understanding promoted by Aristotle. 85

Secondly, the rigour with which Thomas endeavours to understand the text is testimony to the seriousness with which he wants to understand through the sensible form of the text. ${ }^{96}$ This Aristotelian insight that we know twiversal ideas through the objects of the sensible world represented a departure from those who saw endless allegories spinning off from the language of the text, these allegories themselves akin to the Platonic world of order above the form of this world. ${ }^{87}$ Reading Aristotle encouraged Thomas to sce how letter and spirit, language and thought, history and spiritual meaning could be fruiffully read together. For Thomas, via Aristotle, the intellect, in its unavoidable involvement with the soul-body composite, 88 understood the 'quiddity' of things in their material existence.s" Hence the importance of words, and extracting the meaning of words by a forensic (not genetic) examination of their co-text. Thomas' reading (and commentary) on Aristotle's On Interpretation had convinced him that words were the outward expression of interior thoughts.90 In

\footnotetext{
${ }^{83}$ Pesch, 1974, 589-90, 597-8.

84 Meyer, 1946, 22, points to the influence of Boethius (c. $480-525$ CE) in Thomas' zeal for the division of the text.

${ }^{85}$ e.g. Aristotle, On the Soml IIl, vi, $430 \mathrm{a} 26 \mathrm{ff}$.

${ }^{B 6}$ Torrance, 1962, 261, states approvingly that Thomas' commentaries have 'a sober and judicious quality'.

${ }^{87}$ cf. $S T$ la q. 84 a.5 re. Torrance, $1995,17-20$, "The Platonic distinction between a realm of sense and a realm of pure thought had had an immense influence upon the history of hermeneutics, for even when onc is concerned with the meaning of a text it tends to convey the whole activity of interpretation beyond to the understanding of supersensible and purely intelligible rcality. In other words, it lends to lead straight jnto a sharp distinction between a crude literal sense and an underlying spiritual or philosophical meaning.' (19).

ST la q.84 a.6 ad.2; Lectio V.II. 137

${ }^{39}$ Meyer, 1946, 182-203.

${ }^{90}$ For Aristotle see On Interpretation Bk 1; for Thomas see inter alia ST 1a q.34 a. 1 re.

${ }^{11}$ ST 2a2ne q. 173 a.3 te. So Smalley, 1952, 292, "Transferring his view of body and soul to 'letter and spirit', the Aristotelian would perceive the 'spirit' of Scripture as something not hidden behind or added on 10 , but expressed by the text. We cannot disembody a man in order to investigate his soul; neither can we urderstand the Bible by distinguishing letter from spitit and making a separate study of cach.'
} 
contrast to Platonic understandings of the text, the fext was no mere copy, for there is a truth in the 'whatness' or 'materiality' of the text itself, for,

\begin{abstract}
'with us men, a perfect judgement of the mind obtains through turning to sense-objects which are the first principles of our knowledge'.91
\end{abstract}

Since it is from knowledge of material things that human beings acquire an intellectual knowledge of everything else, ${ }^{92}$ we should expect nothing else from Thomas other than a close attention to the understanding of the words in the text. The division of the text may, at first blush, seem alienating and scholastic, but it is rooted in a conviction that exegesis must be 'forced to follow the text word for word' so that everything which follows is built upon the letter and the immediate meaning of the words. ${ }^{93}$

It is important, however, to end with a corrective. Thomas' attention to the text ultimately derives from the conviction that the Scripltural text itself is the very 'foundation of faith' ${ }^{94}$ The text is the access point to the revelation distilled into the prophet's or apostle's intellect and hence calls for serious reading. ${ }^{95}$ What the Holy Ghost has revealed is the absolute norm for what we can and cannot say aboul God.\% For Thomas this revelation to the apostles and prophets is essential for humanity's salvation,

'The ministers of God are those who preach, namely, Christ, the prophets and apostles. Prcaching is performed by Christ as the one from whom the doctrine originates, by the prophets who

\footnotetext{
"2. S' la q 87 a.3 ad.1.

${ }^{93}$ Pesch, 1974, 590-1.

${ }^{94}$ ST $3 \mathrm{aq} .55$ a.5 rc.

${ }^{95}$ ST 2 a2ae q. 171 a.6 re; 2a2ae q.173 a.2 re. See Elders, 1990, 135; Persson, 1970, 20; Lamb, $1966,11$.

${ }^{96}$ ST la q.36 a.2 ad.1; 2 a2ae q. 11 a. 2 ad. 2.
} 
prefigured this doctrine, and by the apostles who carry out the injunction to preach. ${ }^{\prime 97}$

${ }^{97}$ Lectio JI.II.44; Duffy, 1969, 19. 


\section{Thomas' theological exegesis of 1 Thessalonians 4:13-18}

Equipped with some awareness of how Thomas reads Scripture, we arc now rcady to undertake a study of Thomas' reading of 1 Thessalonians 4:13-18. As we shall soon sec this is a section that discloses Thomas' exegetical triad in operation: the canon, the Fathers, and Aristolle.

For Thomas, Paul's central message is an admonition: the Thessalonians should 'lessen their inordinate sorrow'. ${ }^{98}$ Thomas is aware of the benign dispositions of those who grieve, for the grieving person is mourning the 'dissolution of the frail body', a body which should be taken care of 'for the sake of the soul'.99

Thomas's understanding of death was distinct from the Platonic ideal of the eternal soul's separation from the mortal body. Thomas hovered neatly between the Platonists who held that the human person is the soul imprisoned within a perishable body, and contemporary 'plysicalists' who saw the human person as body alone. Thomas consistently stressed the importance of the physcosomatic unity. ${ }^{100}$ The most perfect form of the human person is the soul-body unity. Death, far from freeing the soul and allowing it to enter into the eternal realm of truth as in Plato's account of the death of Socrates in Phatto, is a sign that things are not how they should be. Death is a 'metaphysical horror', 101 signifying the 'frail' nature of our bodies, ${ }^{102}$

$$
\begin{aligned}
& \text { 'life and health of body depend on its being possessed by } \\
& \text { soul... And so, to the contrary, death, disease and all bodily defects } \\
& \text { imply the lack of cuntrol of body by soul.'103 }
\end{aligned}
$$

The divorce between body and soul at death is unnatural, for our 'form' is provided by the soul, ${ }^{104}$ the immortal soul animating the body. ${ }^{105}$ Death's rude interruption is a

\footnotetext{
${ }^{98}$ Lectio IV.II.92; Duffy, 1969, 34. Reference througlıut this study is made to the divisions of the text set out in l'able 3.

Lectio IV.II.93; Duffy, 1969, 34

${ }^{100}$ Potts, 1998, 342.

${ }^{10 t}$ Rousscru, 1979, 600 .

${ }^{102}$ Lectio IV.Ir.93; Duffy, 1969, 34.

${ }^{103}$ ST 2a2ac q. 164 a.l re.

${ }^{104}$ ST 2a2ac q.175 a.5 re; 3a q.8 a.1 rc; 3a q.54 a. 1 re.
} 
rupture of what is a God-cndowed unity, a horror well elucidated by Thomas' citation from Sirach $41: 1$, 'how bitter is the reminder of you to one who lives at peace among his possessions. ${ }^{\prime 10}$

Despite the importance of the soul to Thomas' anthropology, as we have sech Thomas emphasised the acquisition of knowledge through sensible forms, ${ }^{107}$ a role performed through the soul's union with the body. Thus there is a 'natural relationship in the soul's union with the body, for it is through the body-soul composite that we are rational beings who understand through sensible forms. Death, marking the divorce of the body from the soul, is a perilously unnatural state of being, a state only God's resurrection of our bodies can rectify.

But there is more to say on death. Death is a constant reminder of what Romans 6:23 teaches, 'the wages of sin is death', a wage which robbed man of what was originally his by virtue of justice - his natural desire for immortality. Since the fall of man, we can be assured of one thing, that in the words of Ecclesiastes 7:2, death is the end of all men.' ${ }^{108}$ This post-Fall implication is also obliquely implied later in the lecture, when Thomas refers to angels collecting the dust (pulveres) of the dead, ${ }^{109}$ quite likely a reference to the punishment of Genesis 3:19.

Thus, following the divisions of the lext we set out above (Table 3), in section 1 death is the rupture of the natural soul-body composite; it marks a painful separation from loved ones; it is a reminder both of original sin and of our own inevitable death, and for these reasons some sorrow is permitted.110 But l'aul's warning is that, aware that the dead are merely in a state of 'rest' (Sirach 22:11), we must not grieve like those who believe that the wounds of death are eternal in effect. We need to be reminded that those in Christ are not dead but asleep, that our ultimate destiny is not death but heaven (Phil 3:20). Like the twelve in John's story of Lazarus we need to hear that the dead are merely asteep (In 11:11), and at the call of Jesus will come to new life.

\footnotetext{
${ }_{105}^{105}$ Iestio V.II.137.

${ }^{106}$ Lectio IV.II.93.

${ }^{107} S T$ la q. 84 a. 3 re; 1a q. 84 a.6; 3 a q. 8 a.2 re; 3 a q.30 a.3 ad.2.

${ }^{108}$ Lectio IV.II.93.

${ }^{109}$ Lectio IV.II.98

${ }^{110}$ Lectio IV.II.93.
} 
As people of faith who do not die, but fall asleep in Christ, we believe that we will 'rise again' from where we lie (Psalm 40:9). But more, just as when we sleep our soul remains awake, so when we die our soul will remain 'vigilant' (vigilat).41 Interestingly, drawing on Song of Songs 5:2, Thomas likens our soul to the heart that which gives the body its life and energy. ${ }^{112}$ Therefore, although the physical body is corruptible, the soul is incorruptible, 113 extending beyond death. Whilst the body sleeps at death, the soul remains alert and awake. Thirdly, the restoration we feel after a good night's sleep is a forctaste of things to come, the time when out bodies will be 'raised imperishable' (1 Cor 15:52), and in so becoming incorruptible will enjoy an ctcrnal, deathless union with the soul.114

In section 2 of the text's division we turn in 4:14f to the reason for the warning that we must not grieve 'as others'. There are three stages to Paul's warning: first, 'he establishes the resurrection' (2.1); second 'he rules out the faint suspicion of a delay' (2.2), and thirdly the ontlines the order of resturrection' (2.3).

Thomas understands Paul's words in 4:14 by turning first to 1 Corinthians 15:12, 'if Christ is proclaimed as raised from the dead, how can some of you say there is no resturrection of the dead?' It is this very same verse which Thomas cites in the first question of the Stmma Theologiae, where he discusses theology's status as a scientia. For Thomas sacn doctrina advances from what it takes on in faith to demonstrate what is caused by this first principle. Taking the resurrection of Christ as a first principle, a principle known only by faith, Thomas seeks to articulate (via Aristotle's insight that 'whatever is first in a given genus is the cause of all that comes after il: ${ }^{\prime 15}$ ) how our resurrection is captured within a continuum of cause and cffect. ${ }^{116} \mathrm{Al}$ this early stage we are therefore introduced to how Aristofelian insights, that Paul is proceeding by 'causal analysis', 117 aids Thomas in understanding the dramatic claim

${ }^{111}$ Lectio IV.I1.93; Duffy, 1969, 35.

It2 Lectio V.1.120; Duffy, 1969, 46, the heart 'is the source of life'.

${ }^{113}$ ST la q.75 a.6 re.

114 Lectio IV.II.93.

115 Metaptysics Il, I. 993b24. Citcd in ST 3 a 1.56 \%. 1 re.

${ }^{116}$ ST là q.1 a.8 re. See Weisheipl, 1974b, 69-70.

117 Lectio IV.II.95; Duffy, 1969, 35. This is not the only place where Thomas says that Paul is aryuing by the means of Aristotelian 'causal analysis'. See also his comments on 1 Thess 2:5 in Lectio II.I.32 and on 1 Thess 2:20 in IX.II.53, "the goodness of the effect is accounted for by the goodncss af the cause' (Duffy, 1969, 22). For 'l'homas commenting on the four classes of cause as sel out by Aristotle in Metaphysics see Connentary on the Metaphysics of Aristotle, Bk V, Lesson 3. 
of 1 Thessalonians 4:14: that the resurrection of lesus is the assurance of our resurrection.

Expanding his exegesis, Thomas claims that Christ is more than just the 'cause' of our resurrection, but also its 'cxemplar' (sed etiam exemplar). ${ }^{118}$ In Christ assuming flesh and rising in bodily form, 119 Christ is thus exemplar for our resurrection. Christ cmbodies, models and prefigures what our resurrection promises to be if, through the sacraments, our lives participate in and replicate his life.120 The issue here is one essentially of conformity to the reparation of our sinful human nature brought about by Christ, an expectation Thomas raises earlier in his commentary,

'We, however, are waiting for two things: firsl, for the resurrection, in order that we may clearly conform to Christ'.121

At the centre of this exemplary causality, and our complete conformity to Christ, lies the hypostatic union between humanity and divinity represented by the incarnation of Christ, the event at which 'Christ assumed (accepit) flesh'. ${ }^{122}$ But, more intricately, for Thomas the Word in human form and risen in human form communicates what is 'truly' (vero) and 'simply' (simpliciter) the function of the Word, 'to revive our souls' ${ }^{\prime 23}$ Thomas here alludes to the two-fold resurrection, spelt out with most clarity in his Compendium of Theology.124 It is the job of the Word of Cod alone to give new life to the souls, and restore them to life with God, and it is the job of the Word 'made

\footnotetext{
4\$ Lectio IV.II.95. Thomas is more suggestive as to the content of this conformily in ST 3a q.56 a.1 ad.I, 'The plan for us was this, that we first conform ourselves to the model of Christ's passion and death in our own mortal lives, and only then attain a participation in the likeness of his resurrection.' The whole of this article is a helpful contribution to the understanding of 'Thomas' exeyesis in I 'Thessalonians. Valkenberg, 2000, 12l, adduces the influence of 'Thonas' Pulline commentaries on the Summa Theologiae at this point. Torrell, 1996, 261-2, is even more effusive, 'these Questions 27.59 of the Tertia reveal a scriptural and Patristic return to sources that would astonish those who do not wish to sec in Thomas anything olher than an impenitent Aristotelian."

119 Lectio IV.II.95, 'Etenim co quod Christus accepil carnem, et in ea resurrexit, est exemplar nostrie resurrectionis.'

${ }^{120}$ Or, as Duffy, 1969,35 , translates it, Clrist is the 'pattern' of our resurrection. See also ST 3a q.56 a.1 ad.3; Conp. Theol. \& 231. As Crotty, 1962, 61, notes Thomas' thinking on the exemplary causality of the resurrection undergnes some development. It is in the third part of the Summa Theologiae that 'Thomas articulates the principle that that which is perfected in the exemplar is imitated by the less than perfect. See also Leget, 1997, 120, 266; O'Meara, 1997, 84.

${ }_{121}^{12}$ Lectio I.I.22; Duffy, 1969, 11. Also Lectio IV.JI.103.

122 Lectio IV.II.95; Duffy, 1969, 35. Cf. ST 3a q.2 a.2.ad.1, a.3 ad.2; 3 a q.33 a.3 re. For 'Thomas' Christology see Healy, 2003, 87. 105; Marsha1l, B.D., 1987, 176-89.

${ }^{123}$ Lectio IV.IT.95; Duffy, 1969, 35.
} 
flesh' to revive our bodies, ${ }^{125}$ and so in the fullness of time to re-unite our risen bodies with our revived souls. Christ, in reviving both our souls and bodies, has thus destroyed the two-fold death that is our soul's separation from God and the body's separation from the soul.

Lest this understanding of Christ as 'exemplar cause' obscure the real mover behind the resurrection. Thomas hastily adds that Christ's resturrection is also the 'efficient cause $^{\prime}$ (causa efficiens) of our own resurrection. ${ }^{126}$ Christ's resurrection as 'efficient cause' this points back to the first cause that is, for Thomas, always God, ${ }^{127}$ who is the ullimate cause of the resturection. Thus Christ is the efficient cause of our resurrection, 'by the power of the divinity united in him' (virtute divinitatis sibi unitae). ${ }^{128}$

The reason why our resurrection is guaranteed is that Christ's humanity was united to God. Christ's body which rose from the dead was no mere body, but 'a body united to the Word of life' (corporis uniti verbo vitae). ${ }^{129}$ Jesus' body operates as 'an instrument of divinity' (instrtumentum divinilatis). ${ }^{130}$ This notion of Christ's instrumental humanity is found throughout 'Thomas' writing, ${ }^{131}$ and represents an idea which he openly adopted from John Damascene's Exposition of The Orthodox Faith. ${ }^{132}$

\footnotetext{
${ }^{124}$ Whatever exact period this opuscule is dated to, it is undoubtedly a work written towards the end of Thomas' writing career. See Chenu, 1964, 332.

${ }^{125}$ Lectio IV.II.95; Duffy, 1969, 35. Cf. Comp. Theol. 231.

${ }^{126}$ Lectio IV.II.95. Cf. ST 3a $\mathrm{q} .56$ a.1 ad.3, "The efficient causality is through the humanity of Christ in which the resurrection took place and which is tike an instrument acting in the power of divinity.' Thomas never saw the exemplary and elficient causalities of the resurrection as mulually exclusive: Comp. Theol. 239.

${ }^{127}$ Lectio Ephesios I.I.12; Lamb, 1966, 48.

${ }^{128}$ Lectio IV.Ir.95; my translation. For the sovereignty of God in his role of 'first cause' (causa prima) see ST 1a q.65 a.3; 3 a q.56 a.l ads. 2 and 4 . For the notion of Christ's union with divinity see ST 3a g.56 a.2 ad.2, "The efficacy of Christ's resurtection extends to the soul not through any" power inherent in the body of the risen Christ but only through the divine power which he has from personal union with the divinity.'

${ }^{129}$ Lectio IV.II.95; my trunslation.

${ }^{1.30}$ Lectio IV.II.95; translation slightly altered.

${ }^{131}$ See Crowley, 1991; Sabra, 1987, 88-94.

192 John Damascene, 'Exposition of the Orthodox Faith', Mr.xv. The notion of Christ's body as an 'instrument' was, however, presaged much earlier by Athanasius in 'On the Incaruation', \$8.
} 
For Thomas, an instrument always enjoys a two-fold distinction: it is always moved by a superior cause, and it always acts in accordance with its own form. ${ }^{133}$ Carefully distingtishing the various guises an instrument can take, ${ }^{134}$ Christ's humanity is not a passive player in the act of resurrection, ${ }^{135} \mathrm{At}$ every stage, Christ's humanity contributes what is proper for it to contribute in this work of salvation. However, in his resurrection's capacity to raise the dead, Christ's humanity witnesses to a higher principle working through it effectually, ${ }^{1.36}$ empowering it to produce an effect quite beyond its own nature. ${ }^{137}$ The relationship between the 'verbo vitae' and Christ's humanity is not competitive, ${ }^{138}$ for in communion they are working towards the same catise, the resurrection of the dead,

'the whole effect proceeds from each, yet in different ways, just as the whole of the one same effect is ascribed to the instrument, and again the whole is ascribed to the principal agent.' 139

In a fascinating parallel Thomas connects our future bodily resurrection with Jesus' miraculous healing of the leper, his favoured illustration of Christ's instrumental humanity. Just as through Jesus' touch of the leper the principal agency of God's power was working, so too through Clrist's resurrection is our resurrection being worked out. The parallel here is one of causality. Jesus ${ }^{r}$ human touch had the effect of healing because of the divine power working through and with his ability to touch. So too Christ's resurrection has the effect of raising our bodies because through the resurrection is working 'the activity of the divine power.'140 Just as through the human touch of Jesus God's efficacious power was working to achieve an effect beyond the capacity of the instrument alone, ${ }^{1+1}$ so too through the resurrection of Jesus' body is there working the 'verbum vitae' to which his risen body is united. ${ }^{142}$ Following this intriguing parallel it is not going too far to suggest that, just as Jesus' touch cured the leper by virtue of the divinity working through his

\footnotetext{
133 ST 3n q. 19 a.l ad. 2 ; q. 62 a.l ad.2.

134 ST $3 \mathrm{a}$ q. 18 a.1 ad.2.

${ }_{135}$ ST 3 a q. 7 a. 1 ad. 3.

${ }^{136}$ ST 3a c. 13 a. 1 ad.2.

${ }^{137}$ ST 3 a 9.62 a. 1 ad.2. Albertson, 1954, 419, 422.

${ }^{138}$ Lectio IV.II.95.

${ }^{139}$ SCG III.lxx. See also ST 1a2 ae q, 14 a, 3 ad.4.

140 Lectio IV.II.98; Duffy, 1969, 37.

${ }^{141}$ ST $3 \mathrm{a} \mathrm{q.19}$ a.1 ad.5. See $\Lambda$ bertson, 1954, 414.
} 
capacity to touch, so too God's working through Christ's resurrection combines to effect something which neither God's power nor Christ's resurrection could achieve alone, namely 'our resurrection.' 143

In positing Christ's humanity as an 'instrument of his divinity', Thomas is thus pointing to the transformation of Christ's humanity in being able to rise again, for 'the very definition of an instrument is that it effects change by being changed itself. ${ }^{144}$ Christ's humanity thus now promises change in us - our resurrection because Christ's divinity and humanity (and all that was achieved within this economy), the principal and the instrtmental, are working towards a single cause which none of them could do without the other. ${ }^{145}$

It is this interpretation, Thomas implicitly declares, which gets at what Paul was supposing when he wrote 1 Thessalonians 4:14 (Et ideo Apostolus, hoc firmiter supponens)..$^{146}$

Thomas' exegesis of 4:14 corroborates recent opinion that Aquinas fruitfully works with a triumvirate of sacra doctrina seu sacra scriptura, God revealed in Christ, and Aristotelian insights. ${ }^{147}$ For just as Aristotle had established that the first in any genus was the cause of all that followed it, ${ }^{148}$ so too is Christ's resurrection 'the cause of our resurreclion. ${ }^{\prime 49}$ Through the instrumentality of Christ's humanity God occupies the role of 'first cause'. ${ }^{150}$ That we know this is accessible only through the sacra doctrina that is 1 Thessalonians 4:14. Thomas' exegesis thus climaxes at the very point where Aristotelian insights, a Christocentric vision, and a commitment to sacra scriptura intersect and cross-fertilise.

It would be wrong therefore to read Thomas as an exegete stupefied by Aristotle and blind to the ways of eisegesis. Thomas' exegesis is fimly Christocentric, though

\footnotetext{
142 Lectio IV.II.95.

${ }^{143}$ Lectio IV.II.95; Duffy, 1969, 35.

14.r $S T$ la q. 110 a.2 arg.3.

${ }^{145} S T 3$ a g. 19 a. 1 ad.5.

I46 Lecrio IV.II.95.

${ }^{147}$ e.g. Rogers, 1995.

${ }^{145}$ cf. Valkenberg, 2000, 123.

${ }^{149}$ Lectio IV.I.95; Duffy, 1969, 35.

${ }^{150}$ ST 1a q.84 a.4 ad.1.
} 
situated in an Aristotelian framework. In the narrative of the general resurrection, generated and propelled by the 'divine power' (virtus divinitatis), ${ }^{151}$ Christ is the causc of our resurrection in his own incarnate right.152. The very resurrection of our bodies is attributed to the power of the incarned One, 'the Word made flesin' itself. ${ }^{153}$ It is through this instrumental power that on the day of judgernent (hence his citation of Isaiah 3:14 and his persistent talk of the "universal resurrection'154) our bodies will be 'renewed' (reintegratio), and our souls and bodies triumphantly reunited as one. ${ }^{155}$

Having established the resurrection, with help from Aristotle, in 4:15 Paul turns to rule out any delay 'in regard to the resurrection' (2.2).156 Paul's concem is not to say something specific about the timing of Christ's coming - it was this misapprehension that led to 2 Thessalonians. Rather, Paul speaks with the Lord's words, words which 'do nof fail' and he is speaking not to his contemporaries, but to all those who survive the persecution of the Antichrist. Such people can be reassured that the living will not receive their 'consolation' before the dead. Rather, turning to 1 Corinthians 15:52, both those who are asleep and those who are alive will receive the glory of the resurrection, 'in a moment, in a twinkling of an eye.' 157

In the third and most complex stage of Paul's reason for the warning of 4:13, Paul outlines 'the order and manner of the resurrection' (2.3). This itself breaks down into three further subdivisions: the cause of the resurrection (2.3.I); the resurrection's order and manner (2.3.2); and finally, a consideration of their 'muttal consolation' (2.3.3). ${ }^{158}$ It is in I Thessalonians 4:16a that these three causes of the resurrection are outlined.

The primary actor in the universal resurrection will be God himself, acting through his 'divine power' (virtute divina), ${ }^{159}$ Paul's reference to the 'trumpet of God' points

\footnotetext{
${ }^{151}$ Lectio IV.II.98; Dulfy, 1969, 37.

${ }^{152}$ Lectio IV.II.98; Dutfy, 1969, 37.

${ }^{153}$ Lectio IV.II.95; Dutfy, $1969,35$.

${ }^{154}$ Lectio IV.II.98 etc.

${ }^{155}$ Lectio IV.II.98; my iranslation.

${ }^{156}$ Lectio IV.II.96; Duffy, 1969, 36.

${ }^{157}$ Lectio IV.11.96; Duffy, 1969, 36.

${ }^{158}$ Lectio IV.II.97; Duffy, 1969, 37.

159 Lectio IV.II.98; Duffy, 1969, 37.
} 
to the principal mover bchind the resturtection: the power of God who 'arouses the dead' ${ }^{\prime 160}$ The resonance of this trumpet is appropriate to the God who calls his people together for war (Wisdom 5:20). Thomas suggests that the 'trumpet' can be understood as a metaphorical reference for 'the divine power' of Christ (virtus divina Christi) present and manifest to the whole world.'161 (Note here how God's power and Christ's power, as distinct from Christ's instrumental humanity, are interchangeable.)

Focusing on the primary cause of our resurrection as God's divine power; we are close to Thomas' thoughts as he outlined them in his Summa Contra Gentiles (125964),

\begin{abstract}
'Resurrection is natural if one considers its purpose, for it is natural that the soul be united to the body. But the principle of resurrection is not natural. It is caused by the divine power alone.. ${ }^{162}$
\end{abstract}

Supplementing this divine power is the instrumental 'power of the humanity of Christ'. ${ }^{163}$ As we have seen, only through this instrumental capacity is the resurrection made possible. In speaking of 'the Lord himself' descending Paul is referring to the 'glorious humanily of Christ' as the catse of our resurrection. ${ }^{164} \mathrm{He}$ will 'come in the same way as you saw him go into heaven' (Acts 1:11), the way not of humility and obedience as in his first coming, but the way of risen, tritumphant glory (Lk 21:27). Indeed, it is with his return that the dead will not just be risen, but reunited with their souls which have remained vigilant throughout the body's slumber. ${ }^{165}$ It is through Christ that the body will be reunited to its 'form', 166 and so this coming will quite aptly be one of glory.

\footnotetext{
${ }^{160}$ Lectio YV.II.99; my translation.

I6l Lectio IV.II.99; Duffy, 1969, 38.

167. SCG IV.lxxxi.

${ }^{163}$ Lectio IV.II.98; Duffy, 1969, 37.

Ist Lectio IV.II.99; Duffy, 1969, 37.

${ }^{165}$ Lectio IV.I.98.

${ }^{160}$ ST 3 a q. 25 a.6 ad.3.
} 
In referring to the time when all 'who are in their graves will hear his voice' (In 5:28), Thomas points to that time when at Christ's call all shall obey his voice. In Christ's presence, 'all the dead' (omnes mortui) shall be raised. ${ }^{167}$ This is a universal resurrection of the blessed and damned (communis resurrectio) ${ }_{f}^{168}$ of which Christ's resurrection is the efficient cause. ${ }^{169}$ This resurrection of all, as a result of the power of Christ's resurrection, stands distinct from the exemplary outworking of the resurrection which speaks more specifically of those who were conformed to his death through baptism'.170 Although all will risc, Christ's resurrection is only of exemplary effect for those who have sought to be conformed to his will, for there is in Thomas' perspective 'a difference between the good and the evil'. ${ }^{171}$

Thirdly, descending the hierarchy, Thomas refers somewhat ambivalently to the third cause of the general resurrection, the archangel's ministry. With God as 'principal cause', Christ's humanity as 'instrumental cause', Thomas coins the term 'ministering cause' to refer to the work of the angels. ${ }^{172}$ Their work will include such tasks as the collection of dust, perhaps an implicif indicator of the role played by angels in the reversal of the curse of Genesis 3:19.173 Thomas is keen to limit the role played by the archangel in the general resurrection. It cannot be the call that raises the dead, for Joln $5: 28$ would seem to indicate that this is a role reserved for Christ. In an attempt to maximise the role played by Christ in the resurrection, the effect is to consign the archangel's role to a rather general sounding 'ministry' ${ }^{174}$

Having discussed the cause of the resurrection (2.3.1), Thomas then turns to $4: 16 \mathrm{~b}-17$, where Paul presents the resurrection's 'order and manner' (2.3.2).175 Thomas subdivides yet further these verses into three points. First, in $4: 16 b$, the treats the

\footnotetext{
167 Lectio IV.II.98; Duffy, 1969,37 (emphasis added).

168 Lectio IV.II.98; Duffy, $1969,37$.

${ }^{169}$ See Crotty, 1962, 89.

${ }^{170}$ Lectio IV.II.95; Duffy, 1969 , 36. So mo ST 3 a q.39 a.5 ad.2 ("the entrance to heaven is opened (hilough baptism.'); $3 \mathrm{a} \mathrm{q.63} \mathrm{a.1} \mathrm{ad.3.}$

${ }^{171}$ Lectio IV.II.103; Dufry, 1969, 40.

172 Lectio IV.II.98; Duffy, 1969, 37.

17 Or, following Leget, 1997, 78, Aquinas views the soul as much stronger than the body. Held together by the soul, with the soul's departure, the body dissolves at death. Cf. Lectio IV.IL.93; ST 3a q. 53 a.1 ad.1.

${ }^{74}$ Lectio IV.II.99; Duffy, 1969,37 . See ST la q.112 a.1 re; 2 a2ae q. 172 a.2 ad.3.

${ }^{175}$ Lectio IV.II.97; Duffy, 1969, 37.
} 
resturrection of the dead'; second, in 4:17a, he considers the meeting of the living with Christ'; third, in 4:17b, 'he refers to the happiness of the saints with Christ'. ${ }^{176}$

Thomas skips over his first point, not least because of the detail he has just gotne into above, and rushes to the exegetical problem presented by $4: 17 \mathrm{a}$, a problem which Aquinas treats as a mini-disputation.

Thomas refers to Jerome's letter 119, written to two monks (Minervius and Alexander) from 'Toulouse. In this letter Jerome reports that some in his time believed that they would never die, before going on himself to read 1 Thessalonians 4:17 metaphoricaliy, that believers will be 'assumed' into the company of apostles and prophets. For Thomas, of course, such a thought would be inconceivable, as he quoted from Romans $6: 23$ at the beginning of his lecture, ${ }^{177}$ dealh represents the wages of $\sin ^{\prime}$. Paul's possible implication in 4:16b-17 that those foumd alive at the time of the judgement would escape death must be avoided at all costs. In a question on original sin in the Summa Theologine, Thomas reveals just exactly what is at stake in implying that some will evade the punishment of death,

'That all men descended from Adam, Christ alone excepted, contract original sin must be firmly held according to Catholic Faith. The denial of this truth implies the error that not all would be in need of redemption through Christ. ${ }^{\prime 178}$

Correspondingly, in this 'sed contra' section of this disputation in his lecture, Thomas turns to a catena of citations from Pat1 in 1 Corinthians and Romans, authoritatively confirming that Christ's return will mark a reversal of the death universally experienced by all those 'in Adam' (1 Cor 15:22).

Thomas proposes to improve upon Paul's reticence. When Christ comes for judgement, those who are found alive will in that moment die and 'immediately' (statim) be resurrected. So minimal will be this time that such people will be

\footnotetext{
${ }^{376}$ Lectio IVII.100; Duffy, $1969,38$.

${ }^{177}$ Lectio IV.II.93.

${ }^{178}$ ST 1 a2ae q. 81 a.3 rc.
} 
'regarded as living' throughout the process. ${ }^{79}$ It is interesting to compare 'lhomas' confident terseness with the notable circumspection of the Prima Pars of his Summa Theologiae on this very same subject,

'The more probable and generatly accepted opinion mainlains that all those living at the time of the second coming will indeed die, then xise again after a little while: more will be said about this in the Tertia Pars. If, however, it be true, as others hold, that these (the living) will never die, we should reply thus: even if these survivors were not actually to dic, the obligation to undergo death as a penalty would remain in them, though the penalty itself would be remitled by God who has the power to pardon the punishment for even actual sins. ${ }^{\prime} 180$

No sooner has Thomas apparently dealt with this little local conflict, than he bumps into the next exegetical quandary. Reading $4: 16 \mathrm{~b}$ and $4: 17 \mathrm{a}$ together would seem to imply that at the general resurrection the dead will rise ahead of the living, who themselves go through their momentary death when they meet Christ. What this endangers is the notion of a simultaneous (simul) general resturrection, ${ }^{181}$ as Paul taught in 1 . Corinthians 15:52, and as was no less important for Thomas' worldview.

Thomas turns to two (unattributed) sources of tradition. The first response, as Thomas reports it, resembles Augustine's views in the twentieth chapter of City of God. Here Augustine, commenting on these same verses, implies that those found alive at Christ's return will experience a short 'sleep' and resurrection as they arc being caught up in the clouds. Thus, for Augustine, it is as the dead are being borne aloft through the air' that those found alive will undergo a sudden death and resurreclion. ${ }^{182}$ This is close to the school of thought as recounted by Thomas, the approach which, as Thomas recounts, reads the 'moment' of 1 Corinthians 15:52 as a

\footnotetext{
179) Lectio IV.II.101; Duffy, 1969, 39.

${ }^{180}$ ST lazae q.81 a.3 ad.1 (written, as we noted in the Introduction, roughly concurrenily with his Thessalonians Leciara).

181 Lectio IV.II.102.

${ }^{182}$ Augustine, 'City of God', XX/20.
} 
brief amount of time' (modico tempore). ${ }^{183}$ Such a position endangers the universal resturrection Thomas is eager to retain.

The other interpretative position reads Patl's statement that the dead 'will rise first' as a pronouncement of dignity, not of temporal order. Thomas is, however, unhappy with this response: it is not necessarily clear that those who suffer under the Antichrist will be less dignified than those who have had the fortune to die before such throes.

Thomas resolves the question in a different way, and so interestingly stands against the interpretative traditions he has cited. All will die and rise simultaneously (simul). Reverting to the authority of the 'Apostle', Thomas clarifies that Paul is not saying that there will be a temporal order of resurrection, that the dead will rise first and then the living. Before the living meet Christ, 'first' (prius) the dead must rise from their slumber. ${ }^{194}$ The text does not therefore endanger the necessity of the universal resturtection - for at the coming of the Lord those alive will experience death and then 'immediately' (simul) experience resurrection along with those who have died before them. ${ }^{185}$ All will rise at the same time. The text thus clarifies the order of rapture - that before the living will be taken up to meet Christ, first they must dic, so that together with the already dead they can rise simultaneously and be taken up in the clouds.

In the clouds the bodies of the saints will be conformed to the glory of Christ's body. ${ }^{186}$ Only the good will be conformed to Christ's glory. ${ }^{187}$ The Marietti edition makes clear that Thomas asks why this conforming of the saints to Christ should happen in clouds. 188 The reason for this gathering together around the body (Matt 24:28) in the space of the clouds is because here the saints are to take on the appearance of God' (deiformitatem), ${ }^{169}$ for God's glory is broadcast through clouds (1 Kings 8:12). Thus, through the same 'divine power' which is the principal cause of

\footnotetext{
18.3 Lectio IV.II.102; Dufiy, 1969, 39.

${ }^{184}$ Lectio IV.II.103.

${ }^{185}$ Lectio IV.II. 103.

${ }^{186}$ cf. ST 2a2ae q. 175 a. 3 arg. $2 ; 3$ a q. 45 a.4 ad.2.

${ }^{187}$ cf. $S T$ (Supplementum) 3a q.75 a. 2 ad.3.

${ }^{188}$ Lectio IV.II.103.
} 
the general resturection, the glory of the saints will be manifest. To those who remain in the world below - the realm which they loved (dilexerunt) -... such 'transfigured' (fulgentia) bodies will appear as clouds above. ${ }^{190}$

In his final sub-division (2.3.2) Thomas indicates the future beatific state of the sainls. Taking 'delight' (fruentes) in his company they shall be with the Lord forever, in the realm where death reigns no more. ${ }^{191}$ And so as saints they will have realised their holy desire, 'to depart and be with Christ' (Phil 1:23).

In his final division (2.3.3), Thomas ends with the consideration that Paul wanted his words to be words of comfort to those who grieve. The Thessalonians, and presumably ourselves, can be assured that the saints will rise 'without suffering any $1058^{\prime} .192$

${ }^{189}$ Lectio IV.II.103; my translation. Cf. ST 1 a c.12 a.5-6. For direct refurences to 'deiformity' in the Summa Theologiae see Willians, A.N., 1999, 35-9.

${ }^{190}$ Lectio IV.II.103; my translation.

${ }^{191}$ Lectio IV.JI. 104; my translation. 


\section{Conclusions}

Thomas ${ }^{r}$ exegesis witnesses to a theologian who reads with total earnestness Paul's miraculous claim, in 1 Thessalonians 4:14, that the resurrection of Jesus is the pledge of our future resurrection. The use of Aristotelian-inspired causality, and of Christ's instrumental humanity, all serve to makc clearer Paul's extraordinary teaching. Thomas' exegesis is borne from a deep and prayerful meditation on God's truth, as revealed in the mysterious words of 1 Thessalonians. Contrary to Protestant critics, like T.F. Torrance, Thumas' exegesis is 'schematised' not to 'the mind of the church' nor to philosophical structures, ${ }^{193}$ but to the revelation impressed upon Paul's intellect. Indeed it is precisely this attention to the words of the apostle which Thomas deploys to counter exegetical tradition on 1 Thessalonians 4:16-17, ${ }^{194}$ Thomas would not have understood the tersion Protestants hold between the Word of God and the church. For Thomas, every resource, ecclesiastical or philosophical, was to be taken captive unto Christ in the service of comprehending revelation. ${ }^{195}$ In the exegesis we have examined Thomas strains hard to hear Panl the apostle's insistence on the causality of the resurrection. We should expect nothing less. For Thomas the revelation which Paul was privileged to carry was essentially a cognitive, intellectual affair - a true perspective into the reality of things and events, and conscquently Thomas' laboured attention to the causality of the resurrection is testament to the extent to which he is committed to the truth of the ideas Paul articulates. 196

This realism is perhaps the most striking aspect of Thomas' rich, multi-faceted, ceaselessly intra-textual exegesis. For Thomas, truth corresponds to reality and to understand the truth of a text is to be conformed to the 'reality signified' by the text's mode of signifying. ${ }^{197}$ For Thomas, 'truth is in the mind in so far as the mind is conformed to the thing understood, ${ }^{\prime}, 158$ and correspondingly that which Scripture makes known (res significata) is to be treated with the tutmost seriousness and attention. 'Truthfud' exegesis must be conformed to precisely what the apostle Paul

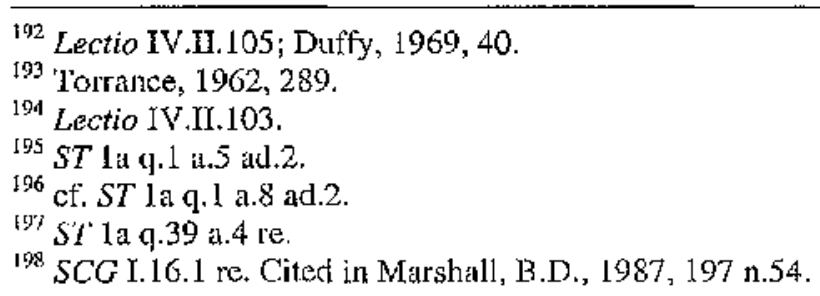


makes known in Scripture and it is for this reason that Thomas follows through so lovingly the causality of Jesus' resurrection, the basis of Paul's extraordinary revelation.

Out of this studied attention to the text arises the immensely potent contribution on Christ's instrumentality. Thomas' use of instrumentality ascribes to the person of Christ a real role in our resurrection. The promise of our resurrection lies in the power held within Christ's humanity united to the Word of iife, for 'the Word made flesh revives our bodies. ${ }^{\prime 19}$ Thomas' stress on the instrumental humanity of Christ, affords that humanity to be saving precisely because every act of this humanity is absorbed within the saving power and will of God himself. There is, in Christ, 'the power of the divinity united in Him.200 This way of articulaling the relationship between Christ's divinily and humanity is laden with eschatological fullness, for Thomas articulates a way of understanding the abiding power of Christ's risen body 'united to the Word of life' (uniti verbo vitae).201 Linking eschatology to a rigorous Christology, Thomas points to an overflowing of this communion of power, an effusion Paul articulates as the resurrection of the dead, and Thomas understands as 'cfficient causality.'

Christ's instrumental humanity thus embraces both the first cause (i.e. God) and the effects desired by the first cause (i.e. the general resurrection). Everything achieved by virtue of this instrument, suffused as it is by the divine power, ${ }^{202}$ participates now in the saving will of God. Thomas' theological exegesis thus allows Christ's resurrection to be itself the foretaste of our resurrection, for the resurrection of Christ is now part of God's power,

\footnotetext{
'it (Christ's resurrection) is the cause of our resurrection insofar as it works by the divine power:' (quod est causa resurrectionis nostrae secundum quod operatur in virtute divina).20:3
}

\footnotetext{
19ectio IV.II.95; Duffy, 1969, 35.

${ }^{200}$ Lectio IV.П.95; my translation.

${ }^{205}$ Lectio IV.U.95; Duffy, 1969, 35.

${ }^{202} \mathrm{ST}$ la2ne q. 112 a.1 ad. $1 ; 3 \mathrm{a}$ g. 19 a.1 ad.1.

${ }^{203}$ Lectio IV.IY.98; my translation (emphasis added).
} 
Thomas' thinking on the resurrection's cause and causalily is, as commentators have noted, 204 a meditation faithful to 'Paul's teaching. In Thomas' thinking the resurrection is restored as a dynamic, active power, willing our future salvation. Paul, too, was intoxicated with the God who raised Jesus from the dead (1 Thess 1:10), and with the belief that there was now, through 'the power of his (Christ's) resurrection' (Phil 3:10), the 'hope of salvation...through our Lord Jesus Christ' (1 Thess 5:9-10). Both Pat1 and Thomas hold in unresolved tension what it is precisely that raises us from the dead. In 1 Thessalonians 4:13-18, Pat1 points to three active causes: God, through Jesus, who will bring with him the dead, and the resurrection itself which points 'in this way' (4:14) to the mode of our future salvation. Thomas, faithful to Paul, also leaves intertwined the three causes of the resurrection of the dead: Christ's resurrection itself, ${ }^{205}$ Christ himself, ${ }^{206}$ and the divine power of the God 'who raises the dead.'207 Fur buth 'lhomas and Pata, what raises us from the dead, and promises us conformity to Christ, is both the same power that raised Christ from the dead, and the resturection of Christ as an effective power for all those 'in Christ'.

Thomas' contribution to exegetical method, and his relationship with historicalcriticism, is just as interesting as his more explicitly theological contribution. For Thomas Paul's intentions are always forged wholly from within the words and literal reference of the text, ars not from any historical-critical reconstruction. Thomas' relentless division of the text, a method that exposes the anatomy of the text, evidences this studied attention to the text. Paul's intention is to be revered precisely because of his status - as one who is an apostle - and not becausc of a general presumption that texts mean what their aulhors intended, a fateful elision of the meaning of the words with a putative, reconstructed historical reference. ${ }^{209}$ Thomas ${ }^{r}$ interest in the literal sense of Scripture was not an attempt to work from a reconstructed intention to the meaning of the words (as with the tendencies we critiqued in Part I), but to take seriously the signification of the words themselves as words over which the ultimate author, God, held providential control.210

\footnotetext{
${ }^{204}$ Healy, 2003, 101; Sabra, 1987, 93; Crotty, 1962, 99. Sec also Stanley, 1961, 20-22.

${ }^{205}$ Lectio IV.II.98.

${ }^{206}$ Lectio IV.II.98.

${ }^{207}$ Lectio IV.11.99; Dutiy, 1969, 38.

$2 \times$ Simalley, $1985,265$.

200 Childs, 1977.

${ }^{210}$ ST la q.1 a.10 re. See Baldner, 1983, 16I-2.
} 
Thomas' suggestive canonical exegesis arises from this commitment to God's providence. The irrepressible canonical conversation 'Lhomas conducts with the text is quite alien to contemporary scholarly predilections that a text's meaning is historically fixed, and not to be related to diverse passages written at different times and in different contexts. Certainly aware of the literary differences to be found within the canon, 211 Thomas promotes the notion that there is a providential aspect to Scripture's meaning. ${ }^{212}$ Dismissed by the unsympathetic as mere proof texting, ${ }^{213}$ Thomas' exegetical method is a lot more interesting than such curt dismissals might suggest. For Thomas there is a truth stretching across the whole of Scripture, precisely because Scripture possesses a prophetic momentum. Biblical authors are 'defective' instruments moved by the principal power, God.214 Consequently there is the capacity for texts to exercise a prophetic function (even if the actual authors of the prophetic texts were tnaware of this movement), ${ }^{215}$ for (God knows all things in their causality. ${ }^{216}$ Thomas would have been baffled by accusations of a-historicism, modern scholars might charge him with, for the God who holds providential control over time and catises knows everything, and everything which Scripture speaks of, in its precise caulsality, as happening in time and through events.217

From this active understanding of God as the cause of everything Thomas deploys Scripture as a vast ecilo chamber with the capacily to explore, tease out and stretch Paul's words. ${ }^{218}$ The texts cited by Aquinas, mote than mere proof texts or decorative additions, witness to Thomas' committed fidelity to the entirety of Scripture, and the remarkable extent to which the text of Scripture, 'has been assimilated into Thomas' own langlage. ${ }^{2: 19}$

Thomas' reading of 1 . Thessalonians, in particular his exegesis of 1 Thessalonians $4: 13-18$, is a reading that is at cvery stage straining forward to an understanding of

\footnotetext{
${ }^{211}$ Psalms, Proemium. See Torrell, 1996, 259-60.

${ }^{212}$ Stump, 1994, 178f.

213 e.g. Blumberg, $1983,93$.

${ }^{214}$ ST $2 \mathrm{a} 2 \mathrm{ae}$ ₹. $173 \mathrm{a}$ a.4 1'e.

${ }^{215}$ ST 2a2ae q. 173 a.4 re.

${ }^{216} S T$ la q. 14 a.13 re.

217 cf. Shanley, 1997.

218 See, for example, fectio M.I.24, where the meaning of the word 'vain' is opened up to a number of possibilities by reference to the canon.

${ }^{219}$ Valkenberg, 2000, 131.
} 
what the text is saying in rcality. For Thomas, indeed, there was an intensity to be attained in the elision of reading and understanding,

"Understanding' implies a certain intimate knowing; to understand, intelligere, is as it were to read within, intus legere. This is evident when you consider the difference between intelligence and sense. For sense-knowledge is engaged with external empirical qualities, whereas intellective knowledge penetrates as far as the essence of a thing....what a thing really is (quod quid est). Now there are many degrees of reality, as it were inside it, to which a man's knowledge should reach. For under its accidents lies the substantial nature of a thing, under words lies what they signify, under likenesses and figures lies the truth which is represcnted'22n

${ }^{220}$ ST 2a2ae q.8 a.1 re (emphasis added). 


\section{Chapter Three: John Calvin and 1 Thessalonians}

\section{Introduction}

John Calvin's (1509-64) theological thinking and study of Scripture enjoyed an organic relationship, the two aspects of Calvin's thinking developing reciprocally. For Calvin the touchstone for all doctxine was Scripture itself, and theology was only ever an aid to purer understanding of the Word. Calvin's frequently cited preface to his 1559 Institutes definitively indicates that his theology pivoted around 'right reading' of Scripture,

'it has been my purpose in this labour to prepare and instruct candidates in sacred theology for the reading of the divine Word, in order that they may be able both to have easy access to it and to advance in it withoul stumbling...If, after this road has, as it were, been paved, I shall publish any interpretations of Scripture, I shall always condense them, because I shall have no need to undertake long doctrinal discussions... In this way the Godly reader will be spared great annoyance and boredom, provided he approach Scripture armed with a knowledge of the present work ${ }^{\prime}{ }^{2}$

Calvin's Iife project was to expound the Bible's clear message. His first Biblical commentary was a commentary on Romans published in 1540, written during a productive sojourn in Strasbourg between 1539 and 1541. Six years later Calvin published his commentary on the Corinthian correspondence, in 1548 on Galatians,

\footnotetext{
' See McKee, 1991; 1989.

${ }^{2}$ Preface to the 1559 Institutes, 4-5. Calvin worked on The Mnstitutes of the Christian Religion throughout his life, constnntly expanding and revising it, often in line with an increased understanding of theological predecessors. These words are found in the 1559 litstitutes, though are first found in his second edition of 1539 (just before the publication of his Romans commentary).
} 
and 1 and 2 Timothy, and in 1549 commentaries on Hebrews and Titus were completed. In 1551, Calvin published his commentary on 1 and 2 Thessalonians. ${ }^{3}$

In line with out reading of Thomas, we will endeavour to undertake a close examination of Calvin's reading of 1 Thessalonians. This will involve us in examining how Calvin reads the Scriptural text, exposing the hermeneutical decisions he makes as he interprets ( $\$ 1$ ). Despite Calvin's reluctance to set out his interpretative decisions, ${ }_{r}^{4}$ no exegete is devoid of a hermeneutical system and it will be our business to unfold Calvin's exegetical methods and strategies. The above reference from the Institutes reveals that it will be faithful to Calvin to tum to this source for occasional illumination. We shall also refer to Calvin's other Biblical commentaries, where they promise to be helpful. Calvin's hermeneutical system will be broken down by examining his attention to the text (\$1.1), to the canon (\$ 1.2), and to Patristic sources (\$ 1.3).

From this grounding, we will be equipped to examine what Calvin says the text says, as before hurning to Calvin's wider corpus to ilfuminate our reflections (\$2). We shall conclude by reflecting on what contribution this voice of tradition, as we have heard it in Calvin's commentary on 1 Thessalonians, is likely to make to ourr reading in Part III (\$ 3).

\footnotetext{
${ }^{3}$ See Parker, 1992. We will be substantially reading from Ross Mackenzie's translation, published in 1961 (republished 1972) in the Calvin's Commentaries series (hereafter cited as Comm. I Thess., followed by chapter and verse). Reference will also be made to the original text of the commentary as found in loanis Calvini opera quae supersunt omnia, volume 52 of the Corpus Reformatortum series. Citations will follow the form of $\mathrm{CO}$, followed by volume and column.
} 


\title{
1. The hermeneutical principles of Calvin's 1 Thessalonians commentary
}

\subsection{Attention to the text}

Calvin's sustained attention to the text itself, with what the text says in its very wording, is often observed. Karl Barth, enthuses in relation to Calvin's exegesis,

\begin{abstract}
'We can leam from Calvin what it means to stay close to the text, to focus with tense attention on what is actually there. Everything else derives from this. But it has to derive from this.' ${ }^{5}$
\end{abstract}

Calvin was a hermeneut of the Holy Spirit. In this regard, as Barth recognised, Calvin is not ultimately fascinated with the text itself, but with the Spirit of God speaking through the text. Properly read, the words of the prophets and apostles act as the instrument by which the Lord dispenses the illimination of his Spirit to believers. ${ }^{\prime} 6$ Calvin's desire is to penetrate so deeply into the text that he enables its ability to speak to us now,

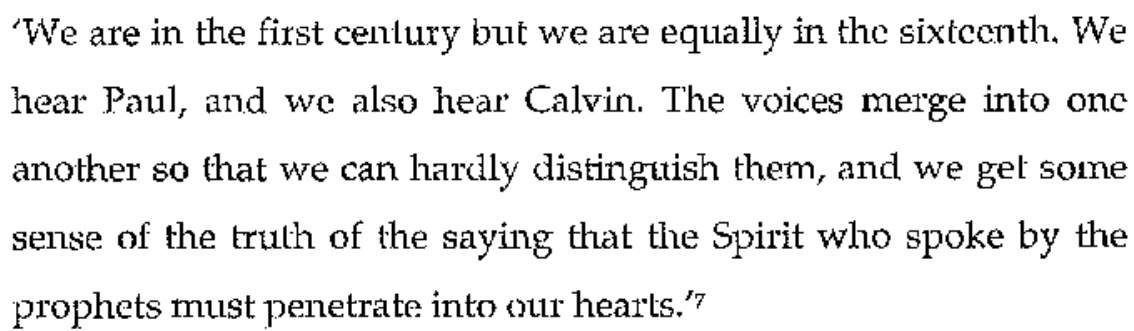

For Calvin the words of Paul are but the 'instrument' of the Spirit of God, ${ }^{8}$ and it is precisely with and through the text that we must seek God's will. To discern the mind and the intention of the author, a frequent concern throughout Calvin's commentary, is to discern the mind of the Spirit, the author's real source of inspiration. The point of connection, the extent to which we can discern the author's intention in our present context of faith, is determined by the extent to which the Holy Spirit is active in the hoart and mind of the individual interpreter." When,

\footnotetext{
${ }^{4}$ Parker, 1971, 49.

${ }^{5}$ Barth, 1995,389 (emphasis original).

${ }^{6}$ Institutes I.ix. 3 (hereafter cited as Inst.).

${ }^{7}$ Barth, 1995, 392.

'Comm. I Thess. 5:20.

9 Forstman, 1986, 51, 'The Bible is not the writer's work but God's lhrough the Holy Spirit; if we
} 
therefore, Calvin states boldly, "Those, therefore, who conclude from this that it is souts which sleep, lack understanding', ${ }^{\prime 0}$ understanding is something always rooted in faith. For, 'only those who have been enlightened by the Holy Spirit have eyes to sce what should have been obvious to all, but is in fact visible only to the elect.'11 'Understanding' is rooted in the reader's foundation in the movement of the same Spixit who inspired the author in the past, and inspires readers now, and so is able to help the reader discem the Word of God within the words of the text. The authority of the Word is, for Calvin, indissolubly bound to the Spirit's activity within the life of the individual believer, ${ }^{12}$ 'This understanding however, should not be understood as purely a mental apprehension, for the truth of Christianily 'is received only whon it possesses the whole soul, and finds a seat and resting place in the inmost affection of the heart', ${ }^{13}$ which as Calvin elucidates is 'the innermost part of the soul.'14

For Calvin the atthority of Scripture resides in the secret testimony of the Spirit reassuring us Scripture is from heaven. ${ }^{15}$ Striking away any interpretative authority the church might assume, Calvin thus turns to a strikingly individualistic doctrine. It is the individual's faith that affirms Paul's authority, and not any chutch that claims to be connected with the same Spirit of inspiration. Calvin's apparent focus on the intention of the author is, in this perspective, an insight into his view of Biblical inspiration, how the I Ioly Spirit transformed mere human words into 'oracles of God $^{\prime}{ }^{16}$ In this way, for Calvin the literal sense is the spiritual sense, for the meaning of the Bible is the meaning ultimately 'intended' by the Spirit. ${ }^{17}$ Calvin's emphasis on the Floly Spirit is always poinling us nof so much towards Paul as author of 1 Thessalonians, but God as Author, an insight correctly apprehended only through faith. 18

receive it as such it is not our perceptiveness but the Holy Spirit tclling us that it is so.' See also Gamble, 1988.

${ }^{10}$ Comm. 1 Thess. $4: 13$.

${ }^{11}$ Comm. 2 Tim. 3:16.

${ }^{12}$ Ihst. I.viii.13.

${ }^{13}$ Inst. III.vi.4. Also Inst, I.v.9; III.ii.36.

${ }^{14}$ Comm. I Thes.. 3: 73 .

15 Inst. I.vii.4.

${ }^{16}$ Inst. IV.viii.9. Cited in Davies, R.E., 1946, 114.

${ }^{17}$ Greenc-MeCreight, 1994, 248 .

${ }^{18}$ Rossouw, 1982, 163. 
Calvin's emphasis on 'authorial intention', from this explicitly theological perspective, is rooted in a conviction that God is Scripture's ultimate Author. ${ }^{19}$ Calvin's emphasis on authorial intention is faithfully pre-critical, ${ }^{20}$ formed from within the movement of the Spirit's activily, the dictation of the Biblical authors, and the faith of the individital reader. ${ }^{21}$

Calvin's profound seriousncss with regard to the Scriptural text had its foundations in his humanist education. It is well known that Calvin was an accomplished humanist, publishing an erudite commentary on Seneca's De Clementia at twentythree. With his conversion, possibly as early as a year later, ${ }^{22}$ Calvin filtered his considerable humanist leaming through his increasingly Reformed perspective..$^{23}$

Where we associate 'humanism' now with the fostering of ethical values independently from any ecclesial or metaphysical contribution, the humanism of Calvin's era was by no means an extra-ecclesial movement, but principally a cultural. and educational movement with origins in the Italian Renaissance. ${ }^{24}$ In its most general form, humanism revered the mastery of the classical languages of Greek, Hebrew and Latin, and admired the style found in the classical writings. In their

19 Inst. I.vii.4.

${ }^{20}$ For a working definition of the term 'pre-critical" see Muller \& Thompson, 1996, 339.41. The term 'pre-critical' is less than satisfactory. It supposes that that there have been two perinds that can be. compartmentalised into 'pre-critical' and 'crilical'. As a result it ignores the inevitable overlap between these two periods. Augustine and Jerome raised textual issues, and Calvin was certainly aware of issues of authorship, disputing the Pauline authorship of Hebrews. O'J oughlin, 1998, has suggested that we focus less on categorising eras by method and more on what the exegete wants to find in his interpretation. Where for 'modern' exegetes the texts of Scripture are part of a successive religious history, for 'pre-modern' exegetes the text is understood Christocentrically, and all exegesis is directed towards the understankling of Christ. In this sense Calvin would certainly appear to be 'premodern'. lis method involved aspects which we might understand now as 'critical', but his end was clear. See Conm. In. 5:39; Comm. Rom. I0:4.

${ }^{21}$ Inst. I.viii. 13 ; I.ix.2.

${ }^{22}$ This is a matter of dispute. For those supporting a 1533 conversion see Hall, 1956, 15. Wendel, 1963, 39-40, opts for a date someline between August 1533 and May 1534. It is important to note that Calvin's conversion need not be seen as a repudiation of humanism. As late as 1559, when Calvin was establishing tha Genevan academy, classics was a major component of the curriculum. Harbison, 1956, 145, notes that the number of cited classical anthors increased in subsequent editions of the institutes. See also Battles 1996, 61-4; Compier, 1992, 217.

${ }^{23}$ For Calvin and humanism sec Bouwsma, 1988, 113-27; Torrance, 1988a, 126-55; McGrath, 1987, 32-68; Linder, 1975 ; Breen, 1968. To do justice to Calvin, one has to give adequate space to the tensive nature of his exegesis. As much as he retained his humanist techniques, he was convinced that the writings of Cicern, Plato and Aristotle were very different in nature from sacred Scripture: Inst. I.viii.1. This development in Catvin, from convinced humanist to one captivated by the Guspel (but still loya! to the insights of humanism) is emphasised by Torrance, cited above. Others, like Buehrer, 1974, stress how Caivin consistently deployed the tools of humanism throughout his church and publishing carreer.

${ }^{24}$ Mann, 1996; Linder, 1975, 168-9. 
elevation of rhetoric humanists selfwconsciously opposed scholastic modes of knowledge. ${ }^{25}$ The clarion call of humanism was a return to the original sources (ad fontes) and a clearing away of what was perceived to be misguided scholastic thought. 26

Basil Hall outlines three distinguishing marks of Biblical humanism, ${ }^{27}$ a movement it should be noted, not restricted to the Reformers. ${ }^{28}$ First, Biblical humanists endeavoured to master the languages of Greek, Hebrew and Latin with the purpose of expositing the Bible more rigorously than their scholastic predecessors. Second, returning to the Bible was seen as the route out of the current intellectual and moral malaise afflicting the church. A return to the straightforward message of the Word of God was the antidote to excessive allegorising. And third, renewed energy was applicd to establishing the most accurate Biblical text. Textual criticism was thus a major facel of Biblical humanism, ${ }^{29}$ and sixteenth century France was a major centre for one of the key facets of humanism: philology. ${ }^{30}$

Calvin's personal heritage in Biblical humanism was exlensive. Wolmar, Cop, Olivétan, Cordier, ${ }^{31}$ Alciati and Bucer were all prominent humanists who either through their teaching or friendship played a part in Calvin's mastery of the apparatus of humanism. ${ }^{32}$ From his brief, but nonetheless influential legal training al Bourges, Calvin had learned much of the technique of moving past the gloss to the most original form of the text,

'Calvin's method of studying the Biblical text is typical of the humanist jurists among whom he had been trained, for the law

\footnotetext{
${ }^{25}$ So Rice, 1961, 134, 'Ftench humanists, in short, associated the theological learning of the scholastics with dialectical pride, sophistry, arid intellcctualism, and an imperfect knowledge of Scripture.'

${ }^{26}$ Bouwsma, 1990, 32-3.

${ }^{27}$ Hall, 1992, 59-60.

${ }^{28}$ c.g. Cardinal Sadoleto whom we shall shortly examine.

${ }^{29}$ Perhaps the most famous father of this revived lextual criticism was Lorenzo Valla (1405-1457). For Calvin's relationship with Valla's method see Myung, 1999, 231-2.

${ }^{30}$ Hall, 1956, 7.

${ }^{31}$ Calvin's Eacher of Latin and French at Paris, to whom Calvin dedicated his 1 Thessalonians commentary. See Battles, 1996, 52-3.

32 'Thompson, 1996.
} 
school of Bourges had made it a first principle to ignore the gloss and to go the earliest and best form of the text. ${ }^{33}$

Calvin's humanist background is evident throughout his commentary on 1 Thessalonians. ${ }^{3-1}$ Reading as a linguist, Calvin also reads the text as a theologian and reformer, one whose close reading of the text is an 'indication that he believes the revelation to have been given word for word by the Spirit. ${ }^{35}$ Approaching the text as inspired by God, with its authors as instruments, Calvin scrutinises the text as closely as possible to gain access to 'the puxe Word of God.' ${ }^{36}$ Reading from Colines' Greek New Testament, an edition based on Erasmus' work and the Polyglot, ${ }^{37}$ Calvin frequently draws attention both to linguistic idioms and text-critical issues pertaining to 1 Thessalonians. ${ }^{38}$ Calvin thus demonstrates the humanist drive to equate purity with origins. ${ }^{39}$

Calvin's disciplined reading fixes attention on Paul's words so that, through these words, we may know what Paul 'connotes' (significat), an 'with what purpose' he speaks (quorsum), ${ }^{41}$ and what his 'nund' (mentem) is.42 Exack rendering of the words used by the apostle Paul is a way of reading Paul faithfully, so preventing 'any unnecessary change in the Greek wording tused by Paul.'40 At 4:15, Calvin states that with the phrase, 'we that are alive', Paul is 'using the present tense in place of the future in accordance with Hebrew usage', and then in commenting on the next verse

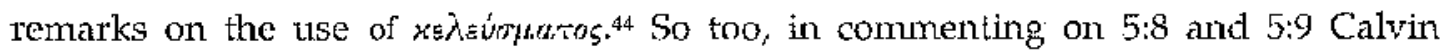
displays a keen interest in the classical languages and their use. One of the humanists' philologically driven concerns was that language both be understood properly, and

\footnotetext{
${ }^{33}$ Hall, 1956, 34.

${ }^{34}$ So Wendel, 1963, 33, 'Just as Luther never managed completely to efface the intellectual imprint of Occam, so Calvin remained always more or less the humanist he had been in 1532.' See also Torrance, 1988a, 161. Kraus, 1992, argues for Calvin's close identification with historical-critical techniques and represents an extreme in the interpretation of Calvin's relationship to humanism.

${ }^{35}$ Duwey, 1994, 99.

36 Comm. 1 Thess. $2: 13$.

${ }^{37}$ Parker, 1971, 106.9.

${ }^{38}$ Comm. 1 Thess. $1: 4,7 ; 2: 5,7,12,13,20 ; 3: 1 ; 4: 6,8,9,10,15,16 ; 5: 4,8,9,13,22$.

${ }^{39}$ Rice, 1961, 134-5.

"10 Comm. 1 Thess 5:15; CO 52:173.

${ }^{41}$ CO 52:140 (on 1 Thess 1:2); my translation.

${ }^{42}$ CO 52:165 (on 1 Thess. 4:13); my translation.

${ }^{43}$ Comm. 1 Thess. 1:7. Interestingly, at Comm. 1 Thess. $2: 13$ Calvin seems so confident that he has accessed Paul's meaning that he adds to the text, "I have, therefore, had no hesitation in inserting the particle ut, which helped to make the meaning more clear."
} 
be interpreted correctly. 45 Calvin accordingly shows an awareness that meormingrs can be interpreted as both 'enjoyment' and 'acquisition' (he translates it as 'obtaining').45

Context was important to humanists in determining whether or not a word was translated correctly: a word's context in the wider passage determines how we should translate it. This could serve as a means of closing down mearing, and settling interpretative debates, as in Calvin's discussion of 1 Thessalonians 2:7.47 Once a certain word is tied down to a grammatical or historical context (or of course both), then this breaks down the endless potential of words as signs pointing to yet more

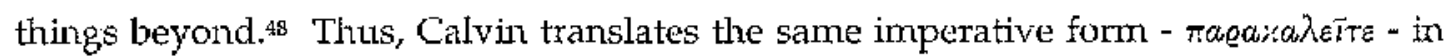
4:18 and 5:11 in different ways according to its literary context. In 4:18 he translates it as 'Comfort', and in 5:11 as 'Exhort', explaining his rationale thus,

'This is the same word which we found at the end of the previous chapter, and which we translated comfort, because the context required it. The same meaning would also suit the present passage quite well. The subjects which he has discussed previously afford material for both, comfort as well as cxhortation." 49

Aside from philological concerns there were rhetorical interests: the identification and categorisation of language in the porticulat context in which it was heing used. Commenting on 1 Thessalonians 5:3, Calvin picks up on Patl's comparison of the 'sudden destruction' with 'a woman with child' as a metaphor.jo Calvin passes further cumments on Paul's metaphorical reference to the faith of the Thessalonians, ${ }^{51}$ to Paul's self-comparision to a nurse, ${ }^{, 2}$ the thief in the night, the pregnant woman, ${ }^{53}$ night and day, ${ }^{54}$ sleep and drunkentuess, 55 and of quenching the Spirit.iti Calvin's

\footnotetext{
${ }^{44}$ Comm. 1 Thess. 4:16.

${ }^{45}$ cf. Zachman, 2002, 10.

46 Comnt. 1 Thess. 5:9.

${ }^{47}$ Comm. 1 Thess. 2:7; CO 52:148, 'Some interprel this to mean, when we might have been a burden, i.e. might have caused you expense. The context, however, requires, (sed contextus postulat) that to Bagú should be taken to mean authority." 'This trait is also evident at Comm. I Thess. 2:12.

${ }_{4 R}$ cf. Bouwsma, 1982.

${ }^{49}$ Comm. I Thess. 5:11.

${ }^{50}$ For Calvin's attention to metaphors see Bouwsma, 1988, 125.

${ }^{51}$ Comm. I Thess. 1:8.

52 Comm. 1 Thess. 2:8.

${ }^{53}$ Both Comm. 1 Thess. 5:3.

${ }^{34}$ Comm. 1 Thess. 5:4.
} 
attention to rhetoric alerts him to when Paul is deploying 'another argument' (aftero argumento), ${ }^{57}$ and when he is mercly developing arguments.58 So too does Calvin betray his keen attention to Paul's varying use of language when he makes reference to the different uses of words relating to armoury in Ephesians 6:14 and 1 Thessalonians 5:8.5\%

Central to Calvin's exegesis were the principles of clarity and brevily, ${ }^{60}$ qualities that distinguished humanists from prolix scholastics. This desire for a purer writing style was not just a humanist endeavour forged in opposition to the perceived verbosity of scholasticism, but was, in its own right, a mode of reading the lext closely with absolute faithfulness. In the dedication of the Romans commentary these principles of brevity are set out with most candour,

\begin{abstract}
'Both of us [Simon Gryaneus and Calvin] felt that lucid brevity constituted the particular virtue of an interpreter... Our desire, therefore, was that someone might be found, out of the number of those who have at the present day proposed to further the cause of theology in this kind of task, who would not only study to be comprehensible, but also try not to detain his readers too much with long and wordy commentaries.'61
\end{abstract}

The motivations for this brevity were rooted in Calvin's attitude that the exegete should clothe himself with htumility before the Word of God for, 'the true meaning of Scripture is the genuine and simple one.'62 To 'turn the meaning of Scripture around wilhout due care' is 'presumpluous' and even 'blasphemous' ${ }^{63}$ Attention to Patt's

\footnotetext{
${ }^{55}$ Conn. I Thess. 5:6.

56 Comn. 1 Thess. 5:19.

${ }^{57}$ Comm. I Thess. $5: 8 ;$ CO 52:170.

${ }^{58}$ Comm. 1 Thess. $2: 1 ; 5: 9$. A clarification is necessary here. Calvin did rend the language of Scripture differently after his conversion, holding that the Word is expressed largely in mean and lowly words, lest, if they had been adorned with more shining eloquence, the impious would scoffingly have claimed that its power is in the realm of eloquence alone.' (Inst. l.viii.1). This confirms Torrance, 1988a, 148, 'he [Calvin] has given up the rhetorical conception of persuasion beloved by the humanists, one that appeals to what is attractive and desirable, and substitutes for it a mode of persuasion which throws the render back upon the truth itself' (emphasis original).

${ }^{59}$ Comm. 1 Thess. 5:8.

${ }^{60}$ See Gamble, 1992a, 1992b; Farrar, 1884, 433-4.

${ }^{61}$ Conm. Rom. (Dedication).

"Comm. Gal. 4:22.

${ }^{63}$ Comm. Rom. (Dedication).
} 
words, and the clear mediation of those words to the church, means that for Calvin there can be no descent 'into an exercise in trivia.'64 The most important task facing an exegete is not the endless play of words, but the simple unfolding of the author's mind. Faced with multiple meanings for 'trump' in 1 Thessalonians 4:16, Calvin curtly states that, 'I will leave it to others to debate in finer detail the meaning of the word trump. ${ }^{65}$ Likewise Calvin is scomful of those scholars who play around with explanations of the different names of the armour in 1 Thessalonians 5:8, complaining that such endeavours are 'pointless' (frustra). ${ }^{66}$ This clarity, and corresponding suspicion of prolixity, is sprinkled throughout the commentary. Commenting on 1 Thessalonians 5:10, Calvin acknowledges the arguments about what kind of 'sleeping' Paul is referring to, but jumps over quickly to what he regards 'is essential' (stumma est). ${ }^{67}$ It is important to nole here, that it is Calvin who makes the interpretative decisions, for it is he who shuts off the potential for an abundance of meaning by declaring, in a seemingly arbitrary manner, what is 'pointless' or 'essential'.

Paul's purpose, as one inspired by the Holy Spirit, is discened from within the very contours of the text. As we have seen, attention to 'the Greek wording used by Paul' is not just attention to what 'he is saying', ${ }^{69}$ but what God's Spiril is saying through Patul. Although it is right to indicate the importance of historical context to Calvin's exegesis, 69 there is restraint in the amount of historical detail discussed in his commentary. Even where historical information is discussed, it does little to distract Calvin from his principal task,70 which is to 'explain[s] Paul's way of thinking' (explicat Patli mentum). ${ }^{7 t}$

Calvin's exegesis is, however, marked by a curious (and pregnant) tension. On the one hand, close study of the Biblical langtuages in their context, had impressed upon Calvin that Paul's words were not the words of his age, but of 'that age' ${ }^{72}$ and that

\footnotetext{
${ }^{64}$ Childs, I970, 15.

${ }^{65}$ Comm. I Thess. 4:16. Cf. Comm. I Cor. 15:52.

"Comm I Thess. 5:8; CO 52:170.

${ }^{67}$ CO 52:171 (on 1 Thess 5:10); my translation.

${ }^{68}$ Comm. I Thess. 1:7.

69 Zachman, 2002, 6-7; Puckett, 1995, 69-70; Krtus, 1992.

${ }^{70}$ Comm. I Thess. 1:9.

$"$ Comm. I Thess. 5:22; CO 52:178.

${ }^{72}$ Comn. 1 Thess. 1:3.
} 
the text contained echoes of the times of Epicurus and Diogenes the Cynic. ${ }^{73}$ Calvin, the humanist, knew that langzlage was context-bound to some degree. ${ }^{74}$ What is revealed in Scripture is limited and defined by its historical provenance. Thus, we should not ask of the text questions Paul was not intending to answer - such as the fate of unbelievers - for 1 Thessalonians is a text whose meaning is limited by 'what suited his [Paul's] present purpose' (quod praesenti instituto congruebat). ${ }^{75}$ We see here an awareness of the difference between then and now, clucidated more fully elsewhere,

\begin{abstract}
'the servants of God should teach nothing which they have not learned from him, still, according to the diversity of the times, they have had diverse ways of learning. But the present order differs very much from what existed in former times. ${ }^{70}$
\end{abstract}

Despite this historical sensitivity to the text, Calvin holds his historical-grammatical tendencies in tension with a conviction that, as an apostle, God called Paul 'according to His own good pleasure.' 77 The author of 1 Thessalonians is a 'superhuman' model for all pastors, ${ }^{\text {7n }}$ whose 'sacred breast' is ablaze with the love of God.79 Echoing his words in the Institutes, that apostles are 'sure and genuine scribes of the Holy Spirit', as a 'holy apostle' Paul has 'learned by revelation all the secrets of the kingdom.' ${ }^{11}$ God commands us by 'the voice of Paul' himself,;2 and consequently God speaks with 'the mouth of Paul' as his instrument. ${ }^{33}$ The inspiration of Paul's words is not overly mechanical however - throughout the process of inspiration Paul retains his individual style,

\footnotetext{
${ }^{73}$ Comm 1 Thess. 1:9.

${ }^{74}$ Bouwsma, 1982, 203f. See Comm. Jn. 6.32; Comm. Jer. 50:18, "We must bear in mind the time - for the meaning of this passage depends on history.'

${ }^{75}$ Comm. I Thess. 4:14, CO 52:165. See also Conm. 1 Thess. 4:16.

76 Inst. IV.viii.5.

${ }^{77}$ Comm. I Thess. 2:4.

${ }^{78}$ Comm I Thess. 2:9.

${ }^{79}$ Comm. 1 Thess. 3:8.

80 Inst. IV.viii.9.

${ }^{81}$ Comm. I Thess, 3:5; 4:15.

${ }^{82}$ Comm. I Thess. 5:19.

83 Comm. I Thess. 5:21.

8. Puckett, 1995, 47 n.24 neatly summarises the most satisfactory response to the well reharsed dabato surrounding Calvin and inerrancy, "It is one thing to say, as Calvin does, that the Holy Spirit is author of scripture; it is conite another to describe the process by which this takes place.' Cr. Davies, R.E., 1946, 114. For the debate on Calvin's relationship with Biblical authority and incrrancy see also
} 
'It is no objection that the article is pul between the pronoun iutwy and the noun Ëerov. We frequently find this in Paul.'s5

Calvin's comments on 1 Thessalonians 4:13f provides some insight into this tensive aspect of Calvin's exegetical hermeneutics ${ }^{\text {ar }}$ Calvin begins by setting out the contextual background within the Thessalonian church, reflecting that it is unlikely that blasphemers had destroyed the hope of the resurrection among the Thessalonians, as had happened at Corinth', and moving on to consider that the members may have retained some of their old superstitions conceming the dead. As if realising the risk of digression, Calvin switches to the main thing (summa)...that we must nol grieve inordinately for the dead, because we are all to be raised again.' ${ }^{\prime}$ Calvin's interest in the text is more than an interest in its linguistic form, or its historical context. lhese are mere props to understanding what God is commumicating through Scripture,

Tt is the Word of God which is the object and goal of faith at which we are to direct our attention, the basis by which it is supported and upheld, without which it cannot even exist.'s

Calvin's attention to the text is dependent upon the relationship he constructs between the Word and the Holy Spirit. It is the Spirit's interaction with the Biblical author, and our connection with that same Spiril, which kecps Calvin's Biblical understanding intratextually generated. For Calvin the meaning is always to be found within the lext, not in any extratextual details spinning away from the text.s\% The author's inspired intention acts as the legitimate restraint on all subsequent interpretation, a meaning arrived at through brevity. It is here that Calvin locates the firmness and clarity of Scripture, to the exclusion of any subsequent, successive lives the words of Scripture may come to enjoy through the Spirit's ongoing activity in the

Dowcy, 1994, 90-105; Packer, 1984; Gerrish, 1982; Nicole, 1982; Prust, 1967; Forstman, 1962; Schaff, $1892,467-8$.

85 Comm. 1 Thess. 1:3. Also Conm. 1 Thess. 3:6.

${ }^{86}$ Noted also by Puckett, 1995, 140-1 and developed more fully by Tiullerton, 1919.

${ }^{87}$ Comm. 1 Thess. 4:13; CO 52:164.

${ }^{88}$ Joannis Calvini Opera Selecta, I, p.69. Cited and translated by Torrance, 1988a, 67 .

${ }^{89} \mathrm{cf}$. Comm. Ezek. 2:1-2,

${ }^{90}$ Comm. 1 Thess. 2:3. 
church. Determined attention to the intention of God as Author through the instrument of the human author was the means by which Calvin cnsured 'pure and faithful instruction in the Word... free from all taint or deception. ${ }^{\prime o}$ Calvin's theology thereby seems to turn the Holy Spirit into an entity of history, at one moment inspiring authors in a context bound way, and at the next moment allowing readers access to that historically limited intent or puxpose. Viewed in this regard, the following words of Calvin on the Holy Spirit's activity secm particularly striking,

'he [the Spirit] would have us recognize him in his own image, which he has stamped upon the Scriptures. He is the Nuthor of Scripture: he cannot vary and differ from himself. Hence he must remain just as he once reveated hims lf there.'

\subsection{Attention to the canon}

We tum now to Calvin's use of Scripture to exposit 1 Thessalonians. One of the most striking differences in comparison with Thomas' commentary on 1 Thessalonians is the restraint with which Calvin cites from the rest of the Biblical canon. Exegeting the nincty-one verses of 1 Thessalonians, Calvin cites only forty-one Scriptural references, which works out at less than one Scriptural reference for every two verses. As we saw, in his commentary on 1 Thessalonians Thomas managed some 329 Scriptural citations, just below four citations for every verse.

Closer examination reveals more restraint. Calvin's preference seems to be to explain Paul by Patl, rather than by the whole of the canon. Of the forty Scriptural references or direct citations, the vast majority are either from the Pauline corpus, or from Luke's narration of Paul's activity in Acts.2. Some thirty (73\%) out of the forty-one Scriptural references are from Pauline epistles, or from Acts. This is an interesting hermeneutical decision, revealing a preference towards understanding the human authorship of Paul, rather than by turning to the whole of Scriplure.

\footnotetext{
${ }^{91}$ Inst. I.ix.2 (emphasis added).

${ }^{92}$ Calvin accepled the Pauline authorship of the Pastorals, Colossians and Ephesians. However, close reading of the text of Hebrews had convinced him that Paul did not write this. For the purposes of this section we are working with the letters Calvin believed to have been written by Paul.
} 
The following breakdown helps clarify Calvin's deployment of the canon;

1) The explicative function of Paul's writings.

One function of the canon is to explain what Paul says reticently or allusively in 1 Thessalonians by turning to what he says elsewhere in his corpus. Explaining Paul's purpose in referring to 'wrath' in 1 Thessalonians 2:16, Calvin understands it to mean 'the judgement of God', as in Romans 4:15 and 12:19.93 Further uses of understanding Paul by Paul (or by Luke's account of his missionary successes in Acts) are found throughout the conmentary. ${ }^{\%}$ But so restrained is Calvin's method of explaining Paul by Paul that he even warms against hamonising 1 Thessalonians 5:8 with Ephesians 6:14, because 'Paul's language here is different.'95

2) The explicative funclion of the rest of the canon.

In these instances what Paul says in 1 Thessalonians is explained with reference to what is said elsewhere in Scripture. No qucstions are raised as to the suitability of this mode of explication, or the compatibility of the different texts. It is assumed that the words of David in the Psalms, or Christ in the Gospels, can explicate Paul's words in 1 Thessalonians. This is not, however, Calvin's favoutred mode of cxplaining Paul.96 One such instance is in exegeting Paul's reference to imitation in 1 Thessalonians 1:6. Here Calvin aligns Paul with Moses, as personalities through whom God works 'as His instruments and servants', and through whom people come to see God's 'generosity', and so might initate God by reciprocating God's gracious love towards them. ${ }^{97}$

3) The contesting witness of Scripture.

In these instances the single, indivisible witness of Scripture to sound doctrine is only accepted after a tussle with passages that might contradict what Paul says in 1 Thessalonians, ${ }^{98}$ Commenting on Patl's reference to the hindrance of Satan in 1 'l'hessalonians 2:18, Calvin juxłaposes Paul's reference to God preventing him from visiting Rome in Romans 1:13. For Calvin 'both statements are true', and he

${ }^{93}$ Conm. I Thess. 2:16.

${ }^{94}$ Conm. 17 hess. $1: 4,9$ (twice); $2: 1,4,9$ (twice), $11,16,18$ (twice); 3:2,10,12;4:1,3,14 (twice); $5: 10,15,16,20,21$ (twicc).

95 Comm. 1 Thess. 5:8.

${ }^{96}$ Comm. 1 Thess. $1: 9 ; 2: 15 ; 3: 2 ; 4: 9 ; 5: 3,4,16$ (thrice), 23.

${ }^{97}$ Contm. I Thess. 1:0́.

98 As Zuchman, 2002, 23-4, notes Calvin held that if we perceived any contradiction in Scriplure this 
harmonizes them by allotting to Satan the ministry of hindrance, and to God the 'stapreme authority to open up a way for us as often as he pleases'.99 'The other verse, 1 Thessalontians 4:16, where Calvin wrestles with the apparently contradictory 1 Corinthians $15: 36$ will be discussed below (\$ 2.6). It suffices to say, that Calvin allows for no contradiction, for the solution to the problem is 'easy' (facilis) ${ }^{109}$

Just as we saw in Calvin's close attention to the text a tensive quality, this is equally present in his rcading of the canon. On the one hand, there is in Calvin a nonnegotiable belief in the absolute unity of the canon. The Spirit of God which inspired Isaiah 60:2 is the same Spirit that inspired 1 Thessalonians $5: 4$ and it is unquestionably legitimate to allow the two to interpret each other. ${ }^{101}$ 'Chis unity in Scripture is obvious to all with the insight of God's Spirit,

'What wonderful confirmation ensues when, with keenex' study, we ponder the economy of the divine wisdom, so well ordered and disposed; the completely heavenly character of its doctrine, savoring of nothing earthly; the beautiful agreements of all the parts with onc another'. ${ }^{102}$

For Calvin the unily of Scriptures is found precisely in the realisation that Christ is its 'real meaning', ${ }^{103}$ from Genesis through to Revelation.t04

Despite the conviction that Scripture was a unificd witness, and that any possible contradiction within its pages could be met with an 'easy' solution, 105 this was held in unresolved tension with insights Calvin drew from Renaissance humanism. Firstly, Calvin believed that a passage's literary context within its time of delivery was a major aid to a passage's meaning. ${ }^{106}$ Secondly, and in conjunction with this, Calvin

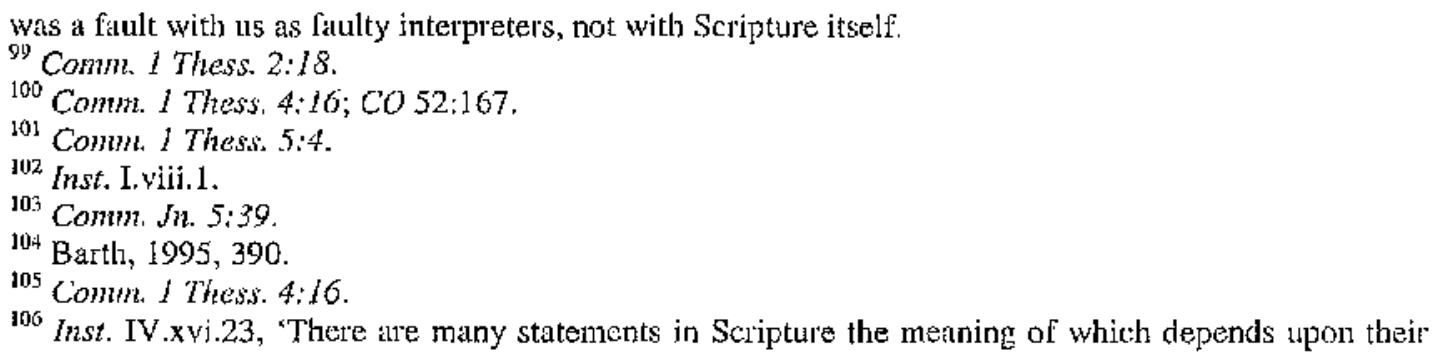


held that the writers of Scripture were teachers, who, as the best teachers, directed their words expertly to their time and context,

'It would be really a frigid way of teaching if the teachers did not determine carefully the necds of the times and what suits the people concerned, for in this regard nothing is more unbalanced than absolute balance.' 107

To be sure, Calvin is never in any doubt that, concerning 1 Thessalonians, 'it was the will of the Spirit of God to spread through all the church the teachings which He has given in this epistie'. ${ }^{108}$ Despite this, Calvin's additional insight was that literary context and historical context was an important determinant in adducing the meaning of a given Biblical text. Surely this conviction is evidenced by the relative paucity of canonical citations (certainly in comparison with Thumas), and the predilection that Paul is best explicated by reference to l'aul, rather than the rest of the canon.

\subsection{Calvin's use of the Fathers}

Calvin had a protound respect for the Fathers. True to the humanist principle of ad fontes Calvin immersed himself in the writings of the early church, and the number of Patristic references grew considerably throughout his successive Institutes. ${ }^{109}$ The prolixity of medieval scholasticism was cast as a departure from the wisdom of the apostolic church and the Fathers,

'All the Fathers with one heart have abhorred and with one voice have detested the fact that God's Holy Word has been contaminated by the subtleties of sophists and involved in the squablles of dialccticians... Why, if the Fathers were now brought back to life, and heard such a brawling art as these persons call

${ }^{109}$ Van Oort, 1997; Hazlett, 1991; Lane, 1981. 
speculative theology, there is nothing they would less stsppose

than that these folk were disputing about God!'110

There was, naturally, a polemical edge to Calvin's use of the Fathers. Immersing himself in the Fathers, and making frequent reference to them, Calvin was consolidating his charge against the Roman Church that it was they, and not he, who had departed from the historic basis and unity of Christianity. As Calvin wrote in his rhetorical xetort of 1539 to Cardinal Sadoleto, 111 the Reformers, far from breaking up the church's unity, were retrieving from the 'ruins' of the present church the 'ancient form' of the church, the age of the apostles and great Fathers such as Augustine, Ambrose and Chrysostom. ${ }^{112}$ The 'secret magic' and 'preposterous riddles' of scholasticism had polluted this purity. ${ }^{113}$ The attack on the Roman Church could find support not just from a return to Scripture, but also the teaching of the Fathers, the very thing Sadoleto and others accused Calvin of renting astunder,

'in attacking, breaking down, and destroying your [the Roman Church] kingdom, we are amed not only with the energy of the Divine Word, but with the aid of the Holy Fathers also. ${ }^{114}$

Nevertheless, Calvin would not be Calvin if he had not insisted that any atthority the Fathers and councils held was always subordinate to Christ and the Word. Our trust in the Gospel must not 'depend on human authority', but solely and always 'on the known and certain truth of God...the pure Word of God' (purum Dei sermonem). ${ }^{115}$ Interpreters musl guard against the invasion of any authority other than the unadorned Word. True authority lay solely with the Word, and any notion of this authority proper to the Word being transferred to the Fathers could not be tolerated, ${ }^{116}$

\footnotetext{
${ }^{110}$ Inst., 22 (Prefatory Address to King Francis). See Buehrer, 1974, 64-103.

${ }^{11}$ For more on this episile sce Payton, 1992; Steinmetz, 1984. T'rking advantage of Calvin's absence from Geneva (he was in Strasbourg), Cardinal Sadoleto had written to the Genevans, urging them to return to the Roman Catholic fold.

112 Calvin, 'Calvin's Reply to Sadoleto', 62.

1 i3 Calvin, 'Calvin's Reply to Sadoleto', 65.

${ }^{1 \text { it }}$ Calvin, 'Calvin's Reply to Saduleto', 73 .

115 Comm. 1 Thess. 2:13; CO 52:151.

116 Torrance, $1988 \mathrm{a}, 71$.
} 
'For atthough we hold that the Word of God alone lies beyond the sphere of our jutdgement, and that Fathers and Councils are of authority only in so far as they accord with the rule of the Word, we still give to Councils and Fathers such rank and honor as it is meet for them to hold, under Christ.' ${ }^{\prime 17}$

Moreover, despite Calvin's respect for the Fathers, it would work against Calvin's stated aim of 'lucid brevity' to tum his Scriptural commentaries into exegetical battlefields. ${ }^{118}$ In general, Calvin avoids sparring with previous Biblical interpreters, or indeed ciling them at all - Calvin is aware that his commentaries (unlike his Inslitutes) are meant to be genuinely accessible.

In the course of our commentary, Calvin makes reference to relatively few exegetical predecessors: Ambrose, ${ }^{19}$ Augustine $_{r}^{120}$ Chrysostom, ${ }^{121}$ and Origen. ${ }^{122}$ This, in itself, reminds us that his simple, straightforward exegesis, was directed towards the building up of all the church. $\Lambda$ s far as possible, Calvin the commentator resolved to do nothing other than 'to mifold the mind of the writer whom he has undertaken to expound.'123 Calvin's preface to his 1557 commentary on the Psalms neatly outlines Calvin's interpretative principles,

'T have not only observed throughout a simple style of teaching, but in order to be removed the farther from all ostentation, I have also generally abstained from refuting the opinions of others, although this presented a more favourable opportunity for plausible display, and of acquiring the applause of those who shall favour my book with a perusal. I have never touched upon opposite opinions, unless there was reason to fear, that by being silent...I might leave my readers in doubt and perplexity...I have

\footnotetext{
${ }^{117}$ Calvin, 'Calvin's Reply to Sadoleto', 92. So also Mast. IV.viii.7; lV.viii.15.

${ }^{\mathrm{t}} 18$ Comm. Rom. (Dedication).

11 Comm. / Thess. 5:22.

${ }^{120}$ Comm. I Thess. 4:16.

${ }^{121}$ Comm. I Thess. $1: 4$ (twice); 4:6; 5:18, 22.

${ }^{122}$ Comm. I Thess. $4: 17$.

${ }^{12 s}$ Comm. Rom. (Dedication).
} 
felt nothing to be of more importance than to have a regard to the edification of the Church." 124

Calvin's 'love' of brevity, ${ }^{125}$ certainly seems behind the reticence with which he cites the Fathers in his 1 Thessalonians commentary. It is also interesting that the Fathess whom Calvin does cites in his I Thessalonians commentary, Origen excepted, are amongst the ones that come in for the highest praise in the aforementioned reply to Cardinal Sadoleto,

'place, I pray, before your eyes, that ancient form of the Church, such as their writings prove it to have been in the age of Chrysostom and Basil, among the Greeks, and of Cyprian, Ambrose, and Augustine, among the Latins; after so doing contemplate the ruins of that Church, as now surviving amongst youtselves. ${ }^{1} 126$

Despite Calvin's stated esteem for Chrysostom, Ambrose and Augustinc, his use of these three reveals an exegetical independence. Of the five references to Chrysostom in the 1 Thessalonians commentary, only one is unambiguously favourable. ${ }^{12 \%}$ In the other references, it is implied that Chrysostom's exegesis is too parsimonious, ${ }^{128}$ that it is 'too forced', 129 that Paul's words 'have a fuller meaning' (pleniorem sensum) than Chrysostom allowed, 13 and that he has failed to 'explain[s] Paul's way of thinking.' ${ }^{311}$ 'l'his is perhaps all the more surprising given Calvin's undispuied high regard for Chrysostom's exegetical principles. ${ }^{132}$ Ambrose, along with Chrysostom, is equally criticised for failing to grasp l'aul's 'meaning' 133

The single reference to Augustine (discussed in \$ 2.6) equally implies a detached criticism. Augustine's concerns over the possible contradiction between 1

\footnotetext{
I2d Comm. Psalms (Preface).

125 Inst. III.vi. I.

${ }^{126}$ Calvin, 'Calvin's Reply to Sadoleto', 62.

127 'i'he first reference in Comm. / Thess. 1:4.

128 The second reference in Comm. 1 Thess. 1:4.

129 Comm. I Thess. 4:6.

${ }^{130}$ Comm. 1 Thess. 5:18; CO 52:175.

131 Comm. I Thess. 5:22.

${ }^{132}$ See Harlett, 1991; Walchenbach, 1874.
} 
Thessalonians 4:16 and 1 Corinthians 15:36, arise because he has trouble understanding how those alive at Jcsus' return can 'rise again.' 131 Once again we must recall that Calvin had an exceedingly high regard for Augustine. Nevertheless, in Calvin's dismissal of Augustine's extended strutggle over the harmonization of 1 Thessalonians 4:16 and 1 Corinthians $15: 36$ - 'the solution is easy'135 - we can hear echoes of criticisms levelled at Augustine elsewhere by Calvin, 136

The last Father to discuss is Origen, who is perhaps not surprisingly dealt with very negatively. Origen's exegesis is an 'aberration[s]' (deliria) and 'too horrible to speak of.' ${ }^{137}$

One cannot draw any general conclusions about Calvin's method of using the Fathexs from the micro-perspective that is the 1 Thessalonians commentary. What we can say, with what we do have, is that Calvin demonstrates a drive to stick to the text, free from protracted debates. Where he does draw on the Patristic heritage it is more often to demonstrate his independence from it, rather than a dependence. For Calvin, it is the Word's authority that tests the contribution of the historical church, not the Patristic inheritance which tests or validales the Word.

\footnotetext{
${ }^{133}$ Comm, 1 Thess. $5: 22$.

${ }^{134}$ Comm. 1 Thess. $4: 16$.

135 Conm. I Thess, 4:16.

${ }^{136}$ Comm. Jer: 28: 7-9; Comm. Ex. 7:22. Both cited by Puckett, 1995, 74 13. 16.

${ }^{137}$ Comm. I Tiess. 4:17; CO 52:167. This is a mild rebuke of Origen in comparison with his other
} 


\section{Eschatology and Calvin's reading of 1 Thessalonians}

Examining Calvin's treatment of eschatology in 1 Thessalonians might seem unpromising. As one commentator reminds us dryly, 'Calvin has never been famous for his eschatology. ${ }^{\prime 138}$ This is perhaps surprising, since for many interpreters the Reformation injected a new sense of dynamism in history. ${ }^{139}$ Just as it possible to read the Reformation as a movement charged with an eschatological momentum, ${ }^{140}$ so too is eschatology a prominent theme of 1 Thessalonians, and in Calvin's reading of the text.

Reading Calvin's commentary closely, with an eye on allusions developed more fully elsewhere in his work, we shall see that it is a work saturated with an eschalological vision. With this eschatological theme ruming throughout the commentary it shall be necessary to distinguish the various threads weaving their way through the commenlary. We propose, then, a six-fold way to understand Calvin's reading of the eschatology of 1 Thessalonians: faith as eschatolugical $(\$ 2.1)$; a dualism between this world and the next $(\$ 2.2)$; a belief in the immortality of the soul ( $\$ 2.3$ ); a propagation of the hidennness of the future (\$ 2.4); an opposition to Chiliasm ( $\$ 2.5$ ); and the universal transformation $(\$ 2.6)$. This exploration of Catvin's reading of the lext shall equip us in our evaluative stage (\$3).

\subsection{Faith as eschatologica1}

For Calvin, faith is a progressive assimilation into the knowledge and love of God, a movement of which God is in full charge. Faith is bound and defined by its end in God's will and love, a ceaselessly progressive momentum 'undcx the direction of the Holy Spirit.' ${ }^{141}$ This theme of an eschatological faith, ${ }^{142}$ a faith orientated towards its end, runs throughout the commentary.

\footnotetext{
comments in Comm. Gen. $2: 8 ; 21: 12 ;$ Comm. 2 Cor: $3: 6$.

${ }_{1.38}$ Holwerda, $1992,130$.

139 e.g. Harbison, 1964, 283, "He [Calvin] is not interested in the divine Essence, because we can never know it, but he is enormously interested in the divine action which we experience in history.'

$14 \mathrm{l}$ Tortance, $1957,39$.

${ }^{14 \mathrm{~L}}$ Comm. I Thess. 5:20.

${ }^{142}$ See also Comm. Phil. 2:70, "the nature of the kingdom of Chist is that it every day grows and improves, but perfection is not yet attained, nor will be until the final day of judgement.' Our way of reading this progress, as a thoroughly eschatological momentum, is not the only way. Battenhouse, 1948,458 , understands this progress as enjoying certain parallels with Neoplatonist philosophy.
} 
Faith, ruming its whole course, is strrounded by God, both at its beginuing and at its end, 'God, as he begins our salvation by calling us, accomplishes it by forming our hearts to obey Him.'143 Faith can only reach its victorious end in and with God because 'there is no perfection among men.' 144 Our salvation is something begun by Christ, for on us 'Christ has begum to shine by the faith of His Gospel'.145 The faith of those who believe in Christ, is nothing less than 'a progress in godliness', 146 a progxess for which it is God who has bestowed superlative gifts upon as for the purpose of perfecting what $\mathrm{He}$ has begur'.147 Failh is depicted by Calvin as a constant forward expansion, true conversion being nothing less than an 'advance in gotliness.' 118 It is God who enjoys the position of being the 'sole author' of the 'whole renewal' of himanily.14\%" Although 'our salvation is based on God's free adoption of $\mathrm{us}^{\prime},{ }^{150}$ and any increase in our love for one another is 'from God alone', 151 bclicvers do have a responsibility to 'fan more vigorously the sparks which God has kindled in them by daily progress.'152

Faith in Christ the believer's continual progress, ${ }^{153}$ is thuts extending towards its perfection, an apex over which God holds authority. The ceaseless ruming towards our victory has as its point of aim God himself ${ }^{154}$ and believers must run this race with 'perseverance'. ${ }^{155}$ It is God who will decide when the fruits of our faith's progress are fully ripe and mature, for only at this stage will Christ return to the world to assume his 'judgement seat', 156

'Paul, however does not explain the nature or the extent of the holiness of believers in this world, but desires that it may be

\footnotetext{
${ }^{143}$ Comm. 1 Thess. 1:6.

144 Comm. I Thess. 4:10.

${ }^{145}$ Comm. 1 Thess. 5:1.

14t Comm. 1 Thess. 3:5.

${ }^{147}$ Comm. 1 Thess. 1:2.

${ }^{148}$ Comm. 1 Thess. 1:9.

149 Conm. I Thess. 5:23. See Quistorp, 1955, 33.

150 Comm. 1 Thess. $2: 12$ (emphasis added).

${ }^{15 !}$ Comm. I Thess. 3:12.

${ }^{152}$ Comm. 1 Thess. 5:19. Thus at Comm. I Thess. 2:12, Calvin juxtaposes the tension between call and response, that "our salvation is based on Gad's free adoption of us....It now remains for us to respond to God's call, i.e. to show ourselves to be such children to Him as IJe is a Father to us.'

${ }^{153}$ Comm. 1 Thess. $4: 1,10$.

${ }^{154}$ Comm. 1 Thess. 2:19.

155 Comm. 1 Thess. 1:2.

${ }^{156}$ Comme / Thess. 4:16.
} 
increased until it reaches its perfection. lor this reason he says at the coming of our Lord, meaning that the completion of what our Lord is now beginning in us is being delayed until that time.' ${ }^{\prime 5 \%}$

Upon assuming his judgement seat, Christ will face two different camps. On the one side he will face those whose lives radiate a faith that has constantly sought to stretch forward to further progress.' 158 Moving under the direction of God, this faith has reached its full ripeness. The deeds of others, however, extend to heaven in a different way. The deeds of the evil - Calvin has in mind the Jews who Paul states are impeding the Gospel's path - are as eschatological as the faithful pursuits of the godly. They too will find their end in God,

'This is why the punishment of the ungodly is often postponed - it is because their acts of ungodliness are so to speak not yet ripe. ${ }^{\prime 39}$

\subsection{The dualism between this world and the next}

One way to sustain this relentless progress into godliness is to obtain a renewed perspective on the world. Calvin is well known for his pessimistic view of what can be attained from this world and from the state of our humanity, ${ }^{160}$ and in his commentary on 1 Thessalonians Calvin maintains a consistent dualism between the glories of the nexl world, and the worthlessness of this world to which we are exiled. ${ }^{\prime \prime i}$

The world which we inhabit is continually interrupted by Satan's wily interferences, ${ }^{162}$ and hence 'the life of Christians is like a perpetual warfare, because Satan does not cease to cause us trouble or to be filled with hatred towards us. ${ }^{1}$ (xis The Christian's faith is based on a hope that there is a better world than this one in which

\footnotetext{
${ }^{157}$ Conm. I Thess. 3:73. See Inst. TV.i. 17 where Calvin talks of the Church advancing and progressing towards its perfection.

${ }^{158}$ Comm. 1 Thess. 4:1.

${ }^{159}$ Comm. I Thess. 2:16.

100 Comm. I Thess. 1:8. Battenhouse, 1948, 462, usefully modifies Calvin's pessimism, ' $A$ nyone who examines Calvin's celebrated pessimism regarding man must. realize that it reflects, actually, a most optimistic view of what man ought to be'.

${ }^{161}$ Inst. III.ix.4.

${ }^{162}$ A frequent apocalyptic theme in this commentary and Calvin's wider thought. Sw Comm. 1 Thess. $1: 1,8 ; 2: 14,18 ; 3 ; 2,5,11 ; 5 ; 8,13,27$.

${ }^{163}$ Comm. I Thess. 5:8.
} 
we are marooned.164 Despite the evidently 'worthless' nature of this world, 165 Christians hope in 'things not seen', 165 a faith waiting ' $m$ intil we behold it in full', 167

\begin{abstract}
'Intent on the hope of the manifestation of Christ they [Christians] are to despise all other things, and armed with patience are to rise superior both to wearisome delay and all the lemptations of the world."16s
\end{abstract}

Unless we are sccurcd and sustained by the hope of eternal life, we will find ourselves drawn to the world.169 This hope of an everlasling life ilself stands radically apart from the world's understanding of death as 'the final destruction', an attitude borne from a worldly arrogance that anything that is taken out of the world is lost: ${ }^{170}$ Calvin draws a parallel between this faith we have in God and the total separation between heaven and earth. As Calvin remarks in his Philippians commentary, to be dead to the world is to be alive to Jesus.171 One cannot have both the world and heaven, rather the eschatological decision must be made. Consequently, our hope in God's saving will is as far removed from conjecture as heaven is from the earth.'172 Trudging through the worldliness of the world, the believer's inevitable weariness is allayed by 'the hope of Christ's coming', marking our 'final redemption. '1/3 At this climactic stage, what is 'hidden' to the eyes of the flesh, and is now ous only as part of 'the secret delights of the spiritual life', ${ }^{174}$ will be broadcast universally. ${ }^{175}$ What we are waiting for in hope is the decisive and culminating resurrection of the dead, ${ }^{17}$ the point at which the whole man is called into eternal life with God. ${ }^{177}$ Armed with this knowledge the Chrislian should not

\footnotetext{
${ }^{164}$ Faith and hope thus operate as vittual synonyms in Calvin's thought: Inst. III.ii.42.

lis. Inst. III.ix. 2.

160 Conun. 1 Thess. 1:9

${ }^{167}$ Comwn. / Thess. 4:16.

${ }^{168}$ Comm. I Thess. $1: 3$.

109 Comm. I Thess, 1:9.

${ }^{170}$ Comm. I Thess. 4: 1.3.

${ }^{171}$ Comm. Phil. 3:20.

${ }^{172}$ Comm. I Thess. 2:13.

173 Comm. I Thess 1:9.

174 ibid. Ci. Comm. I Thess. 5:3; Conme. I Cor. 15:21-2.

${ }^{175}$ See Pitkin, 1999, 64f, on Calvin's exegesis of 1 'Thessalonians 1:10.

${ }^{176}$ Comm. I Cor. 15:18,19.

${ }^{177}$ Comm. 1 Thess. 1:9; 5:23.
} 
grieve over the dead in the same way that non-believers do, for we 'depart from the world in order finally to be gathered into the kingdom of God'.178

The Christian, whose life in Christ provides a new hope for their ultimate end, has new spectacles through which to see the world properly. Placing all our hope in God and Christ, we will see that there is 'nothing in the woxld to bear us up $^{\prime}$.1\% As those who have been 'rescued' from the world's darkness, ${ }^{180}$ the children of light (5:5) live in a world endowed with a keen sense of 'spiritual sobriety'.181 Removing ourselves from the cares and attractions of this world, the Christian's 'whole mind[s]' is now directed to the coming again of Christ: 182 To regard the world correctly, is to view it through the perspective of its end, as something wrelched we pass through on the way to something far more glorious, as Heiko Oberman holds,

\begin{abstract}
"Meditatio futurae vitae" is not only a spiritual exercise, but designates the appropriate mental attitude or frame of mind with which the Christian "sees" and interprets all events in the world and in his own life, namely in terms of the eschaton, "the end"..183
\end{abstract}

\title{
2.3 The obscurity of the future
}

Linked to Calvin's extreme pessimism as to what the world can offer is by way of hope for the future is a consistent emphasis on the obscurity of the future. There are absolutely no resources in the world that can offer us any shape or principle for the timing of Christ's return. Just as the realm of God is far removed from the realm of htuman beings, so we camnot expect to find any clues in this world as to when Christ will return. Equally, this obscurity of the future is rooted in the characterisation of faith as eschatological in scope and direction (\$ 2.1). We must be content with the 'brief glimpse of the magnificent and venerable appearance of the judge' given in Paul's letter, ${ }^{184}$ for 'the meaning of that detiverance will be made plain on the last day'.185 Just as God is in charge of our progress into full perfection, and as we await

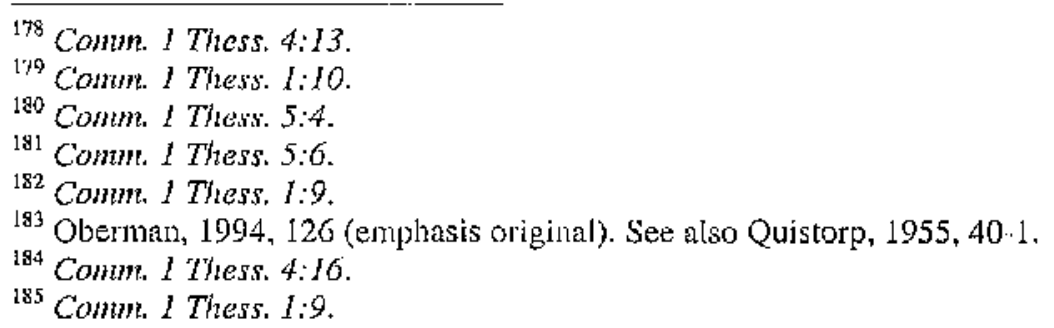


the clarification of what is now 'incredible', ${ }^{186}$ so 100 we should not presume to look for signs of the time in the world around $14 .{ }^{187}$

Christians must know that it is 'foolish to want to determine the time from presages and portents', ${ }^{188}$ and instead must patiently await the return of Christ without the aid of hints or predictions. Indeed it is for this very reason that Paul, who knew by a 'special revelation' that Christ would not come in his lifetime, implies he will still be alive at Christ's return,

'Tis purpose in doing this is to arouse the Thessalonians to wait for it, and to keep all the godly in stuspense, so that they may not promise themselves some particular time.' ${ }^{\prime}$ 'sg

Whether or not Calvin is reacting against the fanalicism and various Spiritzal enthusiasms of his time, ${ }^{190}$ Calvin is evidently keen that 1 Thessalonians is read with restraint. Consequently he emphasises what he regards as the central thrust of 1 Thessalonians 5:1-11, that excessive investigation about times and portents is 'a curious and unprofitable inquiry. "1yn This obscurity of the future is likewise developed in connection with what Calvin says about the symbolic language of 1 Thessalonians. There is a meaning of Scripture whose fullness is properly reserved. By banishing our stupid imaginations,'192 and keeping the focus on 'spiritual sobriety ${ }^{\prime}{ }^{193}$ Calvin is evidently keen that the text of 1 Thessalonians does not become a foil for the indulgence of our curiosity. ${ }^{194}$

\subsection{The immortality of the soul}

In parts of his commentary Calvin is clearly struggling against two exegetical groups. One group were those Anabaptists who advocated the doctrine of 'soul sleep', ${ }^{15}$,

${ }^{186}$ Conm 1 Thess. 4:15.

${ }^{181}$ Quistorp, 1955, 114.

${ }^{188}$ Comm. I Thess. 5:2.

${ }^{189}$ Comm. 1 Thess, 4:15.

${ }^{108}$ Quistorp, 1955, 113.

${ }^{191}$ Comm. 1 Thess. 5:1.

${ }^{192}$ Ittst. I.xiii. 1.

${ }^{103}$ Comm. I Thess. 5:6.

${ }^{104}$ Comm. 1 Thess. $4: 75$.

195 'The term 'Anabaptism' is a less than satisfactory term to encompass a wide diversity of 'Radical Reformation' Inovements. Sec Wyncken, 1992; Rodgers, 1982; Smeeton, 1982; Cooper, 1970; 
against whom Calvin pushed for the immortality of the soul; and another group Calvin opposes in the text are Enthusiastic Chiliasts, against whom Calvin asserts Christ's eternal reign (\$ 2.5).

When laat talks of those who have fallen asleep in the Lord he does not clarify whether he is referring to sleeping souls or sleeping bodies. For Calvin, however, there is no ambigutity,

'The reference, however, is not to the soul but to the body, for the dead body rests in a tomb as on a bed, until God raises the person up. Those, therefore, who conclude from this that it is souls which sleep, lack understanding.' ${ }^{196}$

For Calvin the body sleeps, as though on a bed, and it is a gross misunderstanding to claim that the reference is to sleeping souls. It is the part of us that is perishable that withers away at our 'appoinled death', ${ }^{197}$ and sleeping 'as on a bed' it awails its summoning arousal. The human person, animated by his or her soul, is to look upon the body as 'the house in which he dwells.' ${ }^{198}$ After the 'prison house of the body' has died the immortal and created essence of the soul remains in God's full stewardship.199 When the text thus refer's to our state of slumber this cannot be referring to the soul, for as Calvin indicates later in this commentary, the soul is 'the immortal spirit which dwells in his [sic] body'. 200 Calvin's brevity at this point of his commentary is all the clearer when juxtaposed alongside his denunciations of the 'cancer' that was the sleeping soul error in his 1542 anti-Anabaptist work, Psychopannychia.201 In the context of this 1 Thessalonians commentary, Calvin squared directly with those who read 1 Thessalonians $4: 13$ as a reference to 'soul sleep'. Contraxy to this, Calvin was keen to place our death and resurrection in exact:

Williams, G.I., 1962. It is disputed just how well acquainted Cilvin was with the whole swcep of those advocating some form of 'soul sleep', for while sone held that the soul fell into a state of slumber at denth to be revived at the resurrection of the body (pyschosomnolence), others held that the soul died with the body, only to be completely recovered with the resurrection of the body (thnetopsychism). The range of groups Calvin resisted is indicated in Comm. I Thess. 5:19-21 where he is evidently writing against those Anabaptists best understood as Enthusiasts. Cf. Inst. 1.ix.1; I.ix.3.

196 Comm. 1 Thess. 4:13.

${ }^{197}$ Comm. 1 Thess. 2:16.

${ }^{198}$ Comm. I Thess. 4:3.

199 Inst. I.xy.2.

${ }^{200}$ Conm. I Thess. 5:23. 
conformity to Jesus' death and resurrection, the model of our future.202 Calvin wrestled with what he saw as the folly of soul sleep throughout his wrilings, as evidenced in the typically rhetorical plea from the Institutes,

'Shall we say that souls rest in the graves, that from there they may hearken to Clurist? Shall we not say rather that at his command bodies will be restored to the vigor which they had lost?'203

There is little room to explore to what extent Calvin is being faithful to the Biblical message of the resurrection of the dead, or whether he is importing into his exegesis remnants of classical philosophy, ${ }^{204}$ a debate prominent in recent Calvin studies. Some have argued that Calvin operates with an un-Christian and Platonic dualism. From the perspective of this commentary, however, the dualism Calvin is most clearly operating with is that between spirit and flesh,

'let us learn to fear the vengeance of God which is hidden to the eye of flesh, and take our rest in the secret delights of the spiritual life.'205

In this brief commentary Calvin does indeed refer to the body as the soul's dwelling place, which is akin to passages in the Institutes where the body is understood as a 'prison-house' ${ }^{206}$ Likewise, Calvin uefers cryptically to the mission of the church as 'the eternal salvation of souls'.20\% Calvin manifestly stands closer to the Platonic understanding of the soul, as opposed to the Aristotelian conception.208 What would appear to be crucial for Calvin is that our fleshly existence in the body is something awaiting its own redemption through immortality. The soul is thus 'freed' from the body, not because of an imposition of a Platonic dualism, but because our bodily

\footnotetext{
201 Calvin, "Psychopannyclia', 415 .

${ }^{202}$ Calvin, 'Psychopannychia', 458, 'if you hold that souls sleep becaluse death is called slceping, then the soul of Chi'ist must have been seized with the same sleep.' For secondary resoutces on Psychopanychia see Tavard, 2000; Scholl, 1997; Barth, 1995, 145-56.

${ }^{20.3}$ In.st. III.XXV.7.

204 As argued by Quistorp, 1955; Battenhousc, 1948, 469. For orientation in the debate see Holwerda, 1992, 134; Engel, 1988, 151-87; Partee, 1977, 1969.

205 Comm. IThess. 1:9.

${ }^{206}$ Inst. ILI.ix.4; ПI.vi.5

${ }^{207}$ Comm. 1 Thess. 5:12.

2ust Inst. I.v.5, 11.
} 
existence, as Calvin sees it, is weighed down by our fleshly, corrupt existence. ${ }^{209}$ Far from setting body and soul against each other, Calvin alludes to their essentially holistic salvation. Only until God raises the 'man' (hominem) up from his tomb, 210 is our 'true and complete integrity' restored to us in full.21 Our bodily resurrection marks, for Calvin, the disposal of our body's 'quality', 212 the shedding of that fleshly part of us which is corrupt and a 'defilement'.213 Eternal life, the 'final resurrection' that will free us from the flesh's 'impelling force', ${ }^{214}$ is thus the restoration of the zohole of the individual. Expositing Paul's reference to the 'spirit and soul and body' in 1 Thessalonians $5: 23$, Calvin articulates a holistic approach to our salvation, reminding us that 'Patl....commits to God the keeping of the whole man with all its parts'.2:5

\subsection{Calvin's opposition to Chiliasm}

The second school of thought Calvin denudes of any standing is that which he appears to associate with Origen: Chiliasm. ${ }^{216}$ Calvin's exegesis of 4:17 is set out in opposition to the aberrations of Origen and of the Chialists'.217 Catvin identifies with Origen the teaching (based on Revelation 20:1-7) that believers would live with Clurist in a yet to be renewed earth for the limited time span of a thousand years. 'This is an interpretation to which Calvin is vigorously opposed, not least because it would mean Christ was limited to reigning for only a thousand years, which 'is too horrible to speak of.'218 In limiting our lives with Christ to only a thousand years, st1ch foolish interpretations degrade Christ, for it is clear that 'believers must live with Christ for as long as He himself will exist.'219 Christ's life and believers' lives now intertwined, to speak of one is to speak of the other, and so to degrade the hope of our lives is to

\footnotetext{
${ }^{209}$ Calvin, ${ }^{2}$ sychoparnychia', 443, 'The body, which decays, weighs down the soul..... when we put off the foad of the body, the war between the spirit and the flesh ceases. In short, He mortification of the flesh is the quickening of the Spirit.'

${ }_{210}^{210}$ CO 52: 164; my translation (on 1 Thess 4:13).

${ }^{2.11}$ Ihst. I.xV.4

${ }^{212}$ Comm. 1 Thess. $4: 16$.

${ }^{213}$ Comm. 1 Thess. 4:3. See also Comm. / Cor 15:50.

${ }^{214}$ Comm. 1 Thess. $4: 15 ; 1: 6$.

${ }^{215}$ Comm. 1 Thess. 5:23.

${ }^{236}$ This is a curious reference as it is well attested that Origen resisted millenarianism. Scc Hill, 1992, 127-41; Daley, 1991, 42; Cronzel, 1989, 1.55; Hanson, 1959, 344-5; Bietenhurd, 1953, 20-1. It is interesting that in Inst. IIL.xxv.5, the only other place where Calvin combats Chiliasm, Origen is not mentioned. For discussion of Origen's eschatology see Daley, 1991, 47-60.

${ }^{217}$ Comm. I Thess. 4:17.

${ }^{218}$ Comm. 1 Thess. 4:17.

${ }^{219}$ Connn. I Thess. 4:17.
} 
drag down the glory of Christ, as Calvin indicates in his brief refutation of Chiliasm in the Institutes,

\begin{abstract}
'Those who assign the children of God a thousand years in which to enjoy the inheritance of the life to come do not realize how much reproach they are casting upon Christ and his Kingdom. ${ }^{220}$
\end{abstract}

Believers thtus should look forward to nothing but the eternal Kingdom, 'the promise of eternal life with Him.'221 Christ has defeated death and so lives eternally. Christians must believe that this same power, which Jesus enjoys in union with God, will be communicated to them, ${ }^{222}$ is indeed already at work in them, ${ }^{213}$ and will call them into eternity. The manifestation of Christ's glory being far greater than our childish imaginations, Christ's reign points to a time 'when sin is blotted out, death swallowed up, and everlasting life fully restored!'224

\title{
2.6 The universal transformation
}

In his remarks on 4:16-17 Calvin engages directly with the exegesis of Augustine. For Calvin, the sudden change when we are taken up into the clouds will be 'like death', for when the living are taken up the destruction of their 'flesh' will suffice as a 'kind of death' (mortis species),225 Thus both the living and the dead shall rise into the presence of Christ, and there need be no contradiction with Paud's statement in 1 Corinthians 15:36, that a seed cannot grow again untess il dies.

Augustine is not so easily reconciled to these possible tensions in Paul's thinking. ${ }^{226}$ In the City of God, XX, a section explicitly mentioned by Calvin, Augustine wrestles with the apparent problem - are those whom will be found alive upon Jesus' return never to experience death? Augustine considers the possibility that while we are being carried through the air the living pass with 'wondrous swiftness' from death to

\footnotetext{
${ }^{220}$ Inst. IIl.xxv.5. Ses Holwerda, 1992, 147; Quistorp, 1955, 158-62 for discussion of Chilinsm and Calvin.

2his Comm. Ithess. 4:17.

Comm. I Thess. 3:11.

${ }^{223}$ Comm. I Thess. 2:13.

224 Inst. III. XXY.5.

${ }^{225}$ Comm. I Thess. 4:16; CO 52:167.

${ }^{226}$ See Daley, 1991, 251 n.29.
} 
immortality.227 For Augustinc, it is not an option merely to state that 'it is impossible for them to die and to come to life again while they are being borne aloft through the air. ${ }^{228}$ Augustine focuses on the clouds, or the air in which we shall meet Jesus. For Augustine, Paul's statement that 'we shall ever be with the Lord' (4:17) is a statement that expresses our state of eternal life in union with Jesus. In such a state we shall have 'everlasting bodies', and so be with Jesus Christ 'everywhere'.229 Logically, therefore, there can be no possibility that it is the air in which we are to remain forever.

Augustine's concern is the contradiction-free unity of Scripture's witness. Nevertheless, the words of Paul in 1 Corjuthians 15:22, 'That which thou sowest is not quickened, except it die', are difficult to reconcile with those of Pawl in 1 Thessalonians, unless there is some form of death. For Augustine, if men are to rise to the new life of immortality, then in some way they will have had to 'return to the earth by dying'.230 For not just the integrity of Paul's words in 1 Corinthians is in jeopardy, but so too is the very post-Fall punishment of Genesis, that 'Dust thou art, and unto dust shalt thou return' ${ }^{231}$ Atugustine thinks he is faced with the possibility that 'we shall have to confess that those whom Christ will find still in their bodies when He comes are not included in the words of the apostle and of Genesis. For, being caught tup in the clouds, they are certainly not 'sown', since regardiess of whether they undergo no death at all or die for a little moment in the air, they neither go into the earth nor return to it. 232

Augustine gets out of this apparent impasse by appealing to 1 Corinthians 15:51 which, in its clear reference to rádves, refers lo a change in the state of 'all'. Focusing on the transformation thal will be experienced by 'all', Augustine returns to his earlier supposition and states that there would seem to be no difficulty in holding that as we are caught up, even the living will experience a short 'slecp'. Augustine's appeal is that if we can belicve in the miracle of the restrrection of the dead, we can surely believe that in the ascent through the air, those still in their bodies will pass

\footnotetext{
227 Augustine, City of God, XX/20.

${ }_{228}$ Augustine, City of God, XX/20.

${ }^{229}$ Augustine, City of God, XX/20.

230 Augustine, City of God, XX/20.

231 Gen 3:19.

${ }^{232}$ Augustine, City of God, XX/20.
} 
swiftly from unortality to inmortality. But the question still remains: how does Augustine reconcile this 'sowing' in the air with the clear tcaching of Genesis that 'Dust thou art, and tunto dust shalt thou return'? For Augustine this need not mean that when we die our bodies have to return to the earth as a necessity, but rather it can be understood as essentially meaning, "When you lose your life, you will return to what you were before you received life. ${ }^{\prime 23}$ Thus wherever we die (in the air or on earth) and whenever we die, we cannot but help to return to the form in which we were before we received life. Perhaps aware of his somewhat contorted reasoning arising from the apparent contradictions in 1 Thessalonians 4 and 1 Corinthians 15 Augustine concludes his exposition with the thought that,

'with our inadequate powers of reasoning, we can only guess at how this is to come to pass; and we shall not be able to know until after it has happened." 234

Augustine's prime concern is Scripture's unity, and what it says in one place cannot be contradicted in another. In this sense Augtstine reads like a much more canonically concerned reader than Calvir. would appear at first reading.235

Calvin notes the 'great difficulty' Augustine has with this passage, and states, with perhaps not totally uncharacteristic immodesty, that the solution is 'easy',236 Augustine's wrestling with this text operates as a foil to Calvin's conviction that the meaning of Scripture is clear and ubviotis. Its meaning need not be in doubt, for, 'anyone who opens his eyes by the obedience of faith will see by that very experience

\footnotetext{
${ }^{233}$ Augustine, City of God, XX/20.

${ }^{231}$ Augustine, City of God, XX/20.

${ }^{235}$ Augustine is still wrestling with this text in the third question of his 'Eight Questions of Dulcitius' (written in c. 422). Ilere Augustine is responding to the third query of Dulcitius, "whether those who are lifled up in the clouds will be delivered unto death, unless, perchance, we should accept this change as a substitute for death?' (446). Augustine dwells first on the literal meatning of the text, 'that ccrtain ones, when the Lord comes at the end of the world and there is to be the resurrection of the dead, will not die, hut, found living, will be changed suddenly into that immortality which is given to the other saints.' (447). But no sooner has he clarified this, than Augustino seems dissatistied with it, wrestling with his belief that all must die before they are resurrected, and holding out for the learned men who could convince him of another meaning in face of that which, 'the words themselves seem to cry out.' (448). If, at the return of Christ, that which the texts appenr to cry out is verified (that those who are aljve will not experience death), Augustine surmises, we shall have to return to the canonical texts which would seems to suggest otherwise. But so troubled by Paul's apparent teaching in 1 Thessalonians 4:16-17 is Augustine that he implores Dulcitius tos send him anything he has read on the subject (448).

${ }^{236}$ Comm. I Thess. 4:16. A typical confidence in Calvin's writings. Inst. III.xxv.8.
} 
that Scripture has not been called a lantp for nothing. ${ }^{237}$ For Calvin, moreover, the authority of the Fathers was always functional and pragmatic, should they cluter up the path to discovering the 'mind' (mens) of the author, they could always be neatly cast aside.238

In effect, Calvin appeals to another verse from the Pauline corpus: that it is the corruptible flesh that will be transformed in the act of being caught up is clear from the reference of 2 Corinthians 5:4, that 'what is mortal may be swallowed up by life.' This will be a 'kind of death', ${ }^{239}$ a death which as Calvin implies, and makes clear' elsewhere in the commentary, will not necessitate a separation of body and soul.240 Turning to his own metaphorical reading of death, Calvin appears to poke fun at Augustine's literal rendering of the crecd which speaks of Jesus being judge of the dead and of the living', a reading which leads to Augustine's wandering confusions. ${ }^{241} \mathrm{If}_{x}$ like Calvin, he had concentrated on the destruction of the flesh at the general resurrection, then he would have seen that while the dead put off the substance for a space of time, the living witl rise to put off nothing but the quality (in that they will rise with the same body, but will enjoy incorruptibility whereas before they had been subject to corruption).242 Those still alive at Christ's return will then have their corrtptible flesh transformed suddenly and directly by Christ's 'power' ${ }^{243}$ and will not have to undergo any state where their body slumbers.

For Calvin, the return of Christ will communicale definitively and conclusively to all believers - dead and alive - the salvation he has already achieved within himself. Thus Calvin wites that salvation is something already 'acquired for us by Christ', ${ }^{24}$ for even now 'Christ by His death has delivered tis from the wrath of God.245 Believers however await that glouy which Christ enjoys now, for it was for this reason

\footnotetext{
${ }^{237}$ Comin. 2 Peier 1:19.

73. Inst. II.V.17.

${ }^{239}$ Comm. I Thess. 4:16.

${ }^{240}$ Comm. I Thess. $4: 76$; Inst. III.xxy.8.

${ }^{241}$ Connm. I Thess. 4:16.

${ }^{242}$ Comm. 1 Thess. 4:16. Cf, Inst. III.xxv.7. See also Comm. 1 Cor. 15:51 on the death experienced by the living, 'It will be cleath, then, in that our' corruplible nature will be destroyed; it will not be falling asleep, because the soul will not depat from the body; but there will be a sudden transition fron our corruptible nature to blessed immortality.'

${ }^{243}$ Comm. 1 Thess. 4:16.

${ }^{241}$ Conn. 1 Thess. 5:9.

${ }^{245}$ Comm. I Thess. 1:9.
} 
that Jesus rose from the dead. United to Christ as 'Head', 246 those who are members of Christ's body can be assured of their final resurrection. To be sure, through the Spirit who dwells in us, this wondrous exchange which Christ initiated is already in process, for 'those who are ingrafted into Christ by faith share death in common with him, in order that they may share with Him in life. ${ }^{247}$ Believers therefore, are to place their hope in the universal resurrection at which point oux corrupt flesh will be revived and we will become sharers in his glory. ${ }^{243}$ Only with the resurrection of the dead will the quality of our 'greatly corrupted nature' be put off, so that we can receive our 'final redemption'.24" Chrisl's return therefore points to the full effect of his resurrection, the enfolding of his believers within his power, ${ }^{250}$ the extension 'to the whole body of the Church the fruit and effect of that power which He displayed in Himself.' ${ }^{251}$

\footnotetext{
${ }^{246}$ Conm. 1 Thess. $4: 78$.

${ }^{247}$ Comm. I Thess. 4:14. So also Comm. T Thess. 5:10, "we are passing from death into life."

${ }^{248}$ Comm. I Thess. 2:19.

${ }^{249}$ Comm. I Thess. 1:9. Calvin refers pessiruistically to out fleshly existence in Comm. I Thess. 1:6,9; $4: 3 ; 5: 79$.

${ }^{250}$ Comm. I Thess. 5:10.

${ }^{2.51}$ Comm. I Thess. I:I0. Cf. Torrance, 1956, 116.
} 


\section{Conclusions}

Taking leave from our concluding image in Part I - that of pressing the text forward into a ceaselessly progressive momentum - it is timely to conclude with some thoughts as to how Calvin is likely to affect an expansive reading of 1 Thessalonians.

Calvin's reading of the text is based on a resolve to pay attention to the words themselves' ${ }_{r}^{252}$ an earnest desire to stay very close to the text at all times. We agrec that any interpretation of 1 Thessalonians must be accountable and responsible to what is there in the text, but would disagree with how Calvin elides the literal sensc with the spiritual sense. For Calvin, the literal sense is the spiritual sense, and this singularity is discovered through the individual person's faith in the Spirit reading the letters of the text for its inner, spiritual meaning. It is the single, andisputed. meaning of the lext that is its 'brightness',253 and hence at various points in the commentary we witnessed Calvin shutting down meaning and closing down any option of ambigutity. There is little scope in Calvin's hermeneutics for the depth of Scripture's meaning and referent, rather a shrill insistence that the faithful individual alone can grasp Scripture's uncomplicated, unadorned message. Cutting itself off from any dependence on the church's colfective memory, it would not be long before the singularity of the text's meaning, the attempt to grasp Paul's Spirit-inspired mind, would become intermeshed in the historical-critical drive for the reconstructed author's intention, the fateful move extensively critiqued in chapter 1 . In the course of this chapter we have frequently drawn attention to the tense nature of Calvin's exegesis, and it is clear that in his use of humanist techniques of reading, his deployment of the canon, and his employment of tradition Calvin stands very much on the cusp of modernity.

Running against Calvin's desire for 'spiritual sobriety', 251 is our beliel that by connecting the text with the whole, Spirit-led tradition of the church, the infinitely contestable meaning of the text is exposed to its ultimate depth. Whilst we concur with Calvin's serious reading of the text, we tultimately disagree as to how we can

\footnotetext{
252 Comun. 2 Cor: 10:12.

${ }^{253}$ Conm. Isa. 45:19.

${ }^{254}$ Comm. I Thess. 5:6.
} 
claim to 'hold Paul's meaning. ${ }^{255}$ Holding Paul's meaning, for us, will be predicated on the assumption that the text itself is a bearer of plurivocity, not univocality. Crucially, however, we would hold that this multiplicity of meaning is not something imposed on the text, but is proposed by the text's witness, ${ }_{z}^{256}$ and supported by tradition (not least Calvin's commentary!). Equally, we would be keen to display the potential of a reading that exposed itsclf to the richness of the canonical conversation, a possibility which Calvin is reluctant to countenance (no doubt out of fears that Scripture's all-important simplicity might be Iost). Calvin's highly individualistic tunderstanding of the relationship between the believer and Scripture, coupled with his fondness for exegetical clarity, leaves us very uneasy in relation to his seemingly arbitrary pleas of what is the 'main point', 257 what is 'essential', 258 and what is 'pointless.' ${ }^{259}$ In these important ways we disagree with Calvin as to how we encounter' 'the pure Word of God.'260

Turning now to Calvin's theology, as opposed to his hermeneutics, we are most impressed by the dialcctic Calvin maintains between the transcendence of the future, and salvation as a principle already at work in the world. Here, much more than his distracted reflections on the soul and the body, Calvin is being faithful to Paul's driving concern, that salvation is both something achieved and at work (5:9-10), and something that will manifest itself in a mode outside of our expectations $(5: 2)$. This notion of an eschatological faith, a faith already sharing in the life of the risen Christ, and orientated towards the full sharing of his glory, is a theological insight that we will be keen to devclop in Part III. Central to Paul's concern is that the Thessalonians must see the dead as they really are, 'passing from death into life', ${ }^{261}$ This faith in the climactic resurrection of the dead, the triumphant outworking of God's power to all the 'members of Christ' is, ${ }^{262}$ as Calvin recognises, failh in that which is as yet unseen and seemingly impossible to the eyes of the world. ${ }^{263}$ In his stress on the future's

\footnotetext{
${ }^{255}$ CO 52:165, 'Tenemus nunc Puli mentem'.

256 'This mirrors Calvin in that he too thought the singularity of the Word was something proposed by the simplicity of the texts of Scripture.

${ }^{257}$ Conm. 1 Thess. $4: 13$.

2is Comm. 1 Thess. $5: 10$.

${ }^{259}$ Comm. 1 Thess. $5: 8$.

${ }^{260}$ Conm. I Thess. 2:13.

201 Comm. I Thess. 5:10.

${ }^{262}$ Cornmt. I Thess. 4:18.

${ }^{263}$ Comm. I Thess. $\mathrm{J}: \mathrm{O}$.
} 
transcendence Calvin points to faith in the apparently impossible becoming possible, an insight at the very heart of the resurrection hope,

'Eternal life is promised to us, but it is promised to the dead; we are told of the resturection of the blessed, but meantime we are involved in corruption; we are declared to be just, and sin dwells within us; we hear that we are blessed, but meantime we are overwhelmed by untold miseries;....God proclaims that He will come to us inmediately, but seems to be deaf to our cries.' 264

${ }^{264}$ Conm. Heb. 11:1. 


\section{Chapter Four: Conclusion to Part II}

Three centuries separating them, and emerging from divergent confessional traditions, it is rare to find the work of Thomas Aquinas and John Calvin studied within the same volume. Notwithstanding this novelty, it is worth recalling that our thurn to these pre-modern voices arose from chapler 1's critique of recent historicalcritical treatment of 1 Thessalonians. Focus on 1 Thessalonians' histury of interpretation was inspired by the conviction that God's revelation in Christ is a dynamic process, revealed in time and through the tradition of the church's reading of Scripture. We hoped that from Part II we might both learn new things about the reality generating 1 Thessalonians and recover exegetical methods we could deploy in Part III of the thesis.

Before launching into Part III it is necessary, in this short section, to reflect comparatively on how both Thomas and Calvin read the profundity of 1 Thessalonians. At the back of our minds, as we do so, will be the programmatic critiques set out in Part I. We shall then examine to what extent together they have exposed the witncss of the text, or its ultimate reality, as a route in to the task of Part III.

\section{Attention to the text}

For both Thomas and Calvin the text, and what its actual words say, holds an unassailably regnant posilion. There are, however, a number of differences in the way that Thomas and Calvin read the words of the text, as words of Scripture.

For Thomas the words of Paul in 1 Thessalonians are understood by reference to words from both Paul's other writings, and the whole of the rest of the canon. As we argued this openness to the resonance of the canon is founded on a conviction that Scripture's meaning is ultimately grounded in divine providence. Calvin's reading differs in that there is much more attention to the philological and linguistic aspects of the leller (a feature entirely missing from Thomas' reading), a drive which encourages, and certainly encouxaged later interpreters, to read the human authors of the Bible as literary personalities. It requires little imagination to see the link 
between the historical critical project's separation of the form and content of Scripture, and Calvin's dual stress on 'spiritual sobriety', 1 and attention to the 'mind' of the author. ${ }^{2}$ Stressing the literary features of the individual letter there is in Calvin the genesis of the Bible's fragmentation into a library of unrelated, historically siltiated books. This is a development hinted at by Calvin's notable reluctance to relate 1 Thessalonians to the rest of the camon.

Calvin's measure and restraint, not least in his use of the canon, is intriguing when compared to the fecundity of providential meaning Thomas encourages with his understanding of the canon as a vast echo chamber. As we alluded to above, Calvin's push for 'the single true sense of the text', ${ }^{\prime}$ was fateful, and stands uneasily beside the vision articulated in Part $I$, of a text whose fullness of meaning is ceaselessly progressive. Calvin was inherently suspicious of those who talked of Scripture's meaning being 'obscure' or 'ambiguous', as for Calvin the purity of Scripture's meaning was discerned through attention to the author's inspired mind. Thomas, in contrast, allows for a certain 'excess of meaning' to break out through his wide use of the canon. This is a method that sits more comfortably with the ceaselessly expansive reading we outlined in Part I. Nevertheless, it is worth noting that both Thomas and Calvin share a preference to tunderstand Paul by Paul, and this is a trait we equally plan to mirror in Part III.

To clarify, for both Thomas and Calvin there is no Stendahlian distinction between what the text meant and what if means now. For both Thomas and Calvin what it meant is what it means, and vice versa. Neither read the text as sources (as we saw in our study of J.D. Weima) and both, in their own way, read the text as a record of Paul's apostolic witness. Nevertheless, Calvin lays the foundations for the reading of Biblical texts as historical texts, an asstumption that before we state what a Biblical text means, we must begin by reconstructing what it meant. First, as we have noted, there is the separation of 1 Thessalonians from its canonical context, a prejudice that reveals a preference for reading the text as situated in its historical context of production. Second, there is the fondness for reading 1 Thessalonians in its Greek

\footnotetext{
${ }^{1}$ Comm 1 Thess. 5:6.

${ }^{2}$ Comm I Thess. 4:13.

${ }^{3}$ Childs, 1977, 87.

${ }^{4}$ Comm. I Petcr (Dedication).
} 
original and the noted sensitivity to linguistic idioms. The cry of ad fontes, whilst at one level representing a rebuff of the Roman Church Vulgate, further emphasised the reading of Biblical texts as historical texts. As we saw in James Dunn's defence of historical criticism attention to Greek and Hebrew can easily be aligned with a conviction that to undexstand the meaning of a text, or the intention of its author (often elided), is to appreciate that the text's historical context provides the 'fim rule and norm' for the text's contemporary meaning.5

We are not claiming that Calvin was himself a mature, historical-critical scholar. Calvin's evident Patristic literacy is, for example, striking. Likewise, for both Thomas and Calvin there is an massailable conviction that Scripture cannot contradict itsell. Nevertheless in relation to Calvin, much more than can be said for Thomas, there is an uncomfortably close relationship between his exegetical method and the historical criticism we identified and critiqued in Part X. Kicking away tradition's role as an organic link between text and church, and counselling a 'spiritual sobriety', ${ }^{6}$ Calvin's enthusiasm for the 'mind of the author' easily and without much effort became the quest of historical criticism. ${ }^{7}$

\section{Theological contribution}

The results of Thomas' and Calvin's exegesis make for an equally interesting comparison. As we saw, Calvin's reading of 1 Thessalonians is heavily eschatological, a reading that infiltrates every level of his excgesis of 1 Thessalonians. Calvin reads 1 Thessalonians, not by individually examining pericopes in isolation from each other, but by being gripped by that which Paul was gripped by - God's cschatological tritumph in Christ - and following that through in cvery part of his reading of 1 Thessalonians. As we argued in the conclusion to chapter 3, Calvin's eschatology - both its transcendence and its outworking in the world already - is immensely fruitful.

\footnotetext{
${ }^{5}$ Duлn, 1995, 347.

${ }^{6}$ Conm. 1 Thess. 5:6.

${ }^{7}$ Comm. Rom. (Dedication to Simon Grynaeus). For the links between modern historical scholarship and the humanism in which, as we saw, Calvin was so proficient see Kelley, 1970. Louth, 1983, 96101, links the Reformation 'sola Scriptura' principle with the Enlightenment and historical-critical projects which swept away the notion of the Bible as a treasury of meaning in favour of the quest for a single, determinate meaning.
} 
Thomas' contribution to a theological reading of 1 Thessalonians is distinct, though one we intend to utilise no less keenly. Motivated by the conviction that what Paul communicafes is really true, Thomas follows through with utter seriousness Paul's remarkable witness of 1 Thessalonians $4: 14$, and in so doing points to a way of combining eschatology, soteriology, and Christology. This theological rigour is one worth trying to follow in Part III.

Thomas' and Calvin's readings thus complement each other. We draw from Thomas the desire to understand theologically - as much as it is possible to dare to understand Paul's revelation - the central claim of 1 Thessalonians 4:13-18. But likewise we draw from Calvin the willingness and desire that this insight must be conformed to the whole of 1 Thessalonians, as a revelation into God's saving will that can be related to the whole of 1 Thessalonians, even as it lies at its centre. For those like Gerald Shepphard, the results of Calvin's reading of 1 Thessalonians demonstrates his commitment to the 'scope' of Biblical books, an inlerpretalive move which faithfully related the disparate parts of the text to the literary theme, or argiment of the whole text. ${ }^{8}$

We should be careful, however, not to end on a note which uncritically valorises either Thomas' or Calvin's commentaries. There is in both of their commentaries a marked stress on the immortality of the soul, an emphasis which, although held in tension with an emphasis on bodily resurrection, some would see as a remarkably unPatline drive. ${ }^{9}$ Likewise, there are aspects of both 'Thomas' and Calvin's comments on the reaction of the Jews to the Gospel, which we would be happy to leave in their respective centuries. ${ }^{10}$

Overwhelmingly, however, turning to Thomas and Calvin, in reaction to the barrenness of historical criticism, has provided fertile, new ways of reading 1 Thessalonians. In distituction from interpreters like J.D.G. Dunn, both Thomas and Calvin have endeavoured to keep the text and its subject matter bound together, and both (in their different ways) read this subject matter as God's eschatological triumph in Christ. Although in many ways, Calvin reads like a midwife to histotical

\footnotetext{
Sheppliard, 1989.

${ }^{9}$ cf. Cullmann, 1958.

${ }^{10}$ Lectio II.II. 46-8; Conmn. 1 Thess. 2:14-16.
} 
criticism, just like Thomas his reading of the text is governed more by its subject matter, than by judgemenls about its historical context. Their readings have helped us to see new ways to deploy the canon, to turn to the Fathers when they act as guardians of the Word, to seek with full earnestness the driving force of Paul's conviction, and to read with utmost seriousness the apex of Patt's revelation which he makes known in 1 Thessalonians 4:13f: that Christ holds dominion over death. This seriousness with which Thomas and Calvin read Paul's eschatological witness will provide the impetus for the reading of 1 Thessalonians Part III proposes. 


\section{Part III}

\section{A proposed reading of 1 Thessalonians}




\section{Chapter Five: Death and Resurrection in 1 Thessalonians}

\section{Introduction}

Were it not for the insights accrued from both Thomas' and Calvin's commentaries on 1 Thessalonians it would be difficult to discern what interpretative strategies should be prioritised in this proposed theological interpretation of 1 Thessalonians. Calvin evidenced the importance and vitality of an eschatological vision, a vision loyal to the whole of 1 Thessalonians, operating with a tension between the transcendence of the future, and salvation as a principle already at work in the world. We saw, in Thomas' commentary, the potential of a Christological sensitivity to the exegesis of the resurrection's causality charted by the apostie Paul in 1 Thessalonians 4:14.

Standing in this corporate endeavour to understand Paul, like Thomas we will want to wrestle with the causalily of Christ's resurrection, about how the One who died and rose for ts is the pledge of our future salvation. And echoing Calvin we will be keen to develop a mode of reading which has at its core Paul's own eschatological wilness, bul demonstrates that the resurrection of the dead comprises not only the 'crown of the whole Epistle, but also provides the clue to its meaning, from which place light is shed on the whole, and it becomes intelligible, not outwardly, but inwardly, as a unity.'1

Critical fidelity to Thomas' and Calvin's exegetical insights, using their readings as tools in our own conceptual expansion of Paul's wilness, implics that a number of things can be expected in this chapter's method and focus. We will attempt: to integrate and display a combined loyalty to Paul and to the canon; to deploy Christian tradition where it acts as servant to unfold Paul's leaching; to read the entirety of 1 Thessalonians around what both Thomas and Calvin believe to be at its heart, its eschatological stibject matter; and to investigate how a focus on Christ can.

\footnotetext{
'Barth, 1933b, 11. Barth is commenting about the place 1 Corinthians 15 holds in 1 Corinthians as a whole.
} 
re-capture the force of Paul's witness. The mode of reading we will develop in this chapter deliberately stands in contrast to the historical-critical readings critiqued in chapter 1.

Our theological reading of 1 Thessalonians will have at its centre the attempt to make sense of Patt's witness in 1 'Thessalonians 4:14, 'For since we believe that Jesus died and rose again, even so, through Jesus, God will bring with him those who have

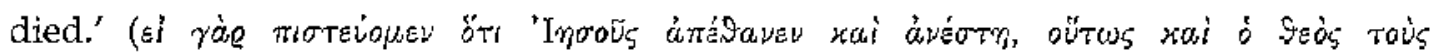

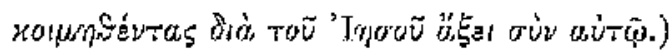

The prime loyalty is to the text itself and the canon (Paul's corpus in particular). Our theological dialogue partners will incorporate selected Fathers of the East and West up until John Damascene's death in $749 \mathrm{CE}$; Thomas Aquinas; the medieval Byzantine theologian, Gregory Palamas (1296-1359); John Calvin; Karl Rahner; Karl Barth; and contemporary Orthodox theologians. There is a deliberate eclecticism to the range of voices we aim to draw upon here, with representatives from the Roman Catholic, Orthodox, Anglican, Reformed, Byzantine Iraditions, and the Patristic period all making appearances at points in this chapter. The purpose in drawing these disparate voices is not to reduce or belittle the very real differences amongst them, but to attempt to bring the richness of Christian tradition (insofar as this chapter can represent it) into conversation with 1 Thessalonians, and so to expose to ever greater depth the witness or ultimate content of this text.

The persistent refrain of this chapter, that attention to the work of God in Christ has the capacity to unravel Paul's meaning, might sound neo-Patristic in tone. In this sense we are saying that Christ is the central mystery of this text, a theme prominent in Calvin's exegesis and one that can be traced back to Patristic meditation on the ultimate meaning of Scripture, 2

'The mystery of the incarnation of the Word contains the meaning of all symbols and enigmas of Scripture, as well as the meaning concealed in the whole of sensible and intelligible creation. He who knows the mystery of the cross and tomb knows also the

\footnotetext{
${ }^{2}$ For Calvin see Comm. Jn. 5:39.
} 
essential causes of all things. Finally, he who penetrates still further and is initiated into the mystery of the resurrection, learns the end for which God created all things in the beginning."

Put simply, our reading of 1 Thessalonians will be 'around Christ', 4 a task that implies both seeking the whole meaning of Christ within Scriptuxe, and treating the person and work of Christ with rigour (insolar as it is patently crucial to know more about the person around whom we are reading the text). Understanding the text and understanding Christ are thus radically reinforcing components of our attempt to do 'theology cxegctically and exegesis theologically.'

We now need to set out something of what the exegesis will look like. In section 1 of this chapter we will commence by identifying the interfaces between eschatological assertions and hermeneutics. These reflections will provide an initial foundation for articulating eschatological assertions about Christ, the central motif of our exegesis.

In section 2 we will tum to an examination of Paul's contribution, setting out some of the parameters in which he must be placed. We will, in turn, critique those who would marginalise the creeds in 1 Thessalonians of most import to us ( $\$ 2.1$ ), and whilst holding that Paul displays no interest in the ontological aspects of Christology, we will argue that 1 Thessalonians presents in primordial form a strong, saving relationship inherent between God and Jesus (\$2.2).

Slowly equipping ourselves textually, theologically, and hermeneutically, in section 3 we will seek to learn more of Christ's saving work, as expressed in the apostolic attestation that Christ died 'Io: us' (I Thess 5:10). Offering three perspectives from which to view the richness of God in Christ's salvific death, we will conclude with the image of Christ's wondrous exchange (\$ 3.3), an image that can both account for the

\footnotetext{
${ }^{3}$ Maximus the Confessor, 'Gnostic Centuries' 1.66, $P G 90,1108$ AB. Translated and cited in Rogich, 1988,149 . For the wider hermententical principles of Maxinus' exegesis see Blowers, 2002, 199 1 . Of course, Maximus was not alone amongst the Fathers for reading the Incarnate Christ as the climax of Scripture, and bence its infallible key. See the exposition of Cyril of Alexandrin's Christ-ruled reading of Scripture in McKinion, 2000, 21 48; Wilken, 1998; 1995.

${ }_{4}^{4}$ 'Reading the Bible', in Williams, R., I994, 157-60 (160). The proposal of tending the Rible with Christ as its barrative centre has recently found support amongst postliberal theologians and narrativists. Loughlin, 1996, is a recent advocale of this reading alpproach to the Bible.

${ }^{5}$ Wilken, 1966, 155, on Cyril of Alexandria's theological style.
} 
depths of Christ's death and prepare us for the theological exposition of our future resurrection.

The fourth section, in which we examine eschatological participation and promise in 1 Thessalonians, forms the climax to this thesis' claim that 1 Thessalonians is capable of considerable depth if we risk exposing it to theological thinking. In section 4.1 we shall set out a tentative survey of images which Patl and the Fathers deployed to grapple with the mystery and meaning of the divine-human encounter in Jesus, and suggest that a simifar commitment to the inexhaustibility of images might help us in the task of understanding Paul's teaching. We shall explore a number of eschatological images present in 1 Thessalonians: images of faith, love, and hope ( $\$$ 4,2); of light and prayer (\$ 4.3); of the 'dead in Christ' (\$ 4.4); of 'sleeping' Christians (\$ 4.5); and of the parousia itself (\$ 4.6). These images, all present within the text of 1 Thessalonians, will be exploited, stretched, and mined to make as much theological sense as we can of Paul's teaching in 1 Thessolonians 4:14: that those who believe in the death and resurrection of Jesus can be assured that, through God, they will be incorporated within the same power. 


\section{(1) Eschatology and hermeneutics}

The exegetical, theological and imaginative task ahead of us is inescapably hermeneutical. It is above all an exposition of how and where the grace in Christ is to be articulated and experienced now. In this way the tunavoidable particularily of the eschatological admonitions of 1 Thessalonians is to be read. The Thessalonians' experience of grace must point us towards understanding how we can trace similax experiences of grace in our hope for the future.

Axiomatic for any theological treatment of eschatology is the conviction that Jesus' future salvific significance is not something reserved to one historical space in time, but is true of Christ in all times. This claim has two central insights. First, the promise of Christ's future is always experienced as expanding out of time's various passages and into the promise of eternity. Second, and as a direct implication of the previous statement, insofar as a theological exposition of Biblical eschatology locates ilself in the future as grace experienced through Christ loday, it is a hermeneutical fatix pas to locate a theology of eschatological grace exclusively through an archaeological project of historical recovery and authorial intention. Such an approach would in reality undermine the necessarily theological (and imaginative) task of articulating the future out of the promise of Christ's grace experienced in the present. These two assertions merit further explication.

Historical commentators often point to Paul's purpose, a purpose helpftlly delimited by what he does not choose to say. Patt's intention is stated clearly in 1 Thessalonians 4:13 - Paul the pastor does not want the Thessalorians to grieve for those who are dead as though death has defeated the purposes of God, ${ }^{6}$

'Paul's intention, however, is not a discourse on the end-time but an attempt to reassure his readers that all faithful believers will be united with their risen Lord.'7

\footnotetext{
${ }^{6}$ Mulherbe, 2000, 161.

${ }^{7}$ Richard, 1995, 248.
} 
The historical context of this eschatological discourse is therefore not how the dead are to be raised, but whether the already dead are to be included in the resurrection heralded by the return of Christ. Will the dead miss out on that glorious resurrection? Patll's answer is a resounding ' $\mathrm{No}^{\prime}$. There is littie talk of the mature of the resurrection itself, merely a pastorally direct reassurance that the dead will not be exempt from the general resurrection. Moreover, although this passage touches on our notions of the general resurrection (and certainly was read as such by Thomas), there is no mention of the universal judgement as at 2 Corinthians 5:10. Paul's words are fixed on responding to a communal concern - grief that the dead will miss out on the general resurrection - with talk of collective eschatology, 'we will be with the Lord forever:' (4:17).

Paul's words in 1 Thessalonians are directed and frustratingly (for some) focused. Paul is not writing for the benefit of systematic, theological reflection. As an occasional piece of titerature there is little of what we would seek answers for in a comprehensive treatment of life beyond death. There is, for example, little evidence of interest in the fate of non-believers (cf. 1:9-10). Paul's words are directed towards grieving believers.

A theological exposition begins by acknowledging that in no situation since the letter's first distribution, and certainly not since it was canonised, has the authority of this letter entirely matched Paul's original intention. The letter's authority has been deemed to lie somewhere other than this irretrievable historical intent - in that which, through the apostle Paul, it communicates, rather than some putative situation it was written to meet. The text's mysterious authority is thus located courtesy of a Aeliberate hermeneutical switch, not in the incongruity of an irretrievable historical context of delivery, but more in the congruity of the insights generated and sustained by the realities of which the text speaks.

Oux theological project thus poses a deliberate hermeneutical challenge. In order to understand that which 1 Thessalonians limelessly communicates the parallels we seek are not the historical, lexical and archaeological parallels favoured by historicalcritics. Rather, if we are to treat what Patil is really talking about as revelation, as that

\footnotetext{
${ }^{8}$ Lectio IV.II. 103.
} 
which we claimed in chapter 1 is ceaselessly profound, we should expect to find resources within the church's widest theological tradition illuminating and expansive. Ultimately this is the fruit of prioritising the subject matter and reality which the text conveys. ${ }^{9}$

Although the Sitz im Leben of Paul's words is not here our prime concern, it cannot be cast aside too glibly. ${ }^{10}$ For the Sitz im leben of all eschatological assertions represents the futurity of Christ's grace experienced in the present. It is this grace that links together in a mysterious continutity the first recipients of 1 Thessalonians and all stibsequent readers (Thomas and Calvin included). What unites all readers and hearers of this text is the grace experienced in the present as eschatological hope and promise. In this sense the seemingly relentless passage of time, measured by human reckoning, is as nothing compared to the grace experienced in the eschatological moment, the grace experienced as the interpretation of our past selves and the anticipation of our futures in extramutandane communion. In this theological perspective ... which has as its nucleus our futures in God - there is less need to turn to some putative historical context as a locus of authority. The ultimate authority which unites all readers of 1 Thessalonians through time is the revelation that our futtres lie in Christ. It is this grace of Christ which is the centre of authority behind all eschatological assertions. Or, being succinct, to speak of eschatology, in all times, is to speak of Christ,

'There is not a single eschatological statement even in the New Testament which allows us to ignore this One. His death, resurrection and coming again are the basis of absolutely everything that is to be said about man and his future, end and goal in God. If this gives way, everything collapses with it.'11

\footnotetext{
'Barth's preface to his second Romans commentary is patently behind much of the thoughts here. Sec Barth, 1933a, 11, 'I entirely fail to see why parallels drawn from the ancient world - and with such parallels modern commentators are chiefly concerned - should be of more value for an understanding of the Epistle than the situation in which we ourselves actually are, and to which we can therefore bear witness.'

${ }^{10}$ For good coverage of the debate on the context behind l'aul's admonitions see Barclay, forthcoming; Matherbe, 2000, 283-5; Wanamaker, 1990, 164-6; Best, 1972, 181-4.

${ }^{11} \mathrm{CD}$ III/2, 623-4. Cited in Anderson, 1986, 75.
} 
The signal essay of the Jesuit theologian Karl Rahner (1904-1984), "The Hermeneutics of Eschatological Assertions', furnishes us with much of the hermeneutical sophistication oux project requires at this stage.

Rahner argues that we should quite rightly enquire into the Sirz in Leben of the Scriptural eschatological pronotncements, aware that in so doing we are dealing with the stuff of 'primordial revelation', upon which anything subsequent is 'derivative and explanatory'.12 Nevertheless, if we want to lalk dogmatically of eschatology we must recall that it must remain talk of that which is fiture. ${ }^{13}$ (There is then something curiously ironic about discussion of Biblical eschatology which remains purely on the archaeological level.) Talking of that which is future is a necessarily risky task epistemologically, not least because in the present there is always an important part of the future which is hidden in darkness and obscurity. Eschatology is talk of the future, from the basis of the present, a future that is known now only as mystery, as hidden. What God reveals is preciscly this - that the future is not to be known predictively. ${ }^{14}$ This hidden quality to the future is more than obvious and platitudinots - it: is the very basis of hope. 15

Talking of the future in the present implicates us in a dialectical process, a location in a present properly orientated towards the mystery of the future, the understanding of the present in such a manner that knowledge of the future necessarily 'grows out of $t^{\prime} \cdot{ }^{16}$ Just as the Thessalonian Christians were caught up in the process of understanding their eschatological futures in their now, so too in our now are we to talk of our futures in Christ. Knowledge of eschatology is necessarily, therefore, knowledge of how this present can itself be seen as possessing eschatological promise, a bringing into creative tension present and future, experience and promise. Eschatology always involves talking about more than the present. But so too, is our talk of the future (insofar as it can be artictuated) shaped by our eschatological existence in the present.

\footnotetext{
12. Rahner, 'The I Iermeneutics of Eschatological Assertions', (herenfter 'The Hermeneutics') 325. For discussion of the seven theses set out in this atticte see Ludlow, 2000, 136-50; Phan, 1988, 64-76.

13 Rahner, "I"he Hermencutics', 326. Herein is contained Rabner's critique of the cxistentialism associated with Rudolf Bultmann. Eschatology which remains on the level of talking about the 'hele and now' is 'theologically unacceptable' (326).

${ }^{14}$ Rahner, 'The Hertmeneutics', 329.

${ }^{15}$ Rahner, 'The Hermeneutics', 329.

${ }^{16}$ Rahner, "The 'Hermeneutics', 331.
} 
For Rahner, it is the (eternal) experience of Christ's grace which unites the seemingly divergent context of the Thessalonians and what we are to say eschatologically now. ${ }^{17}$ In this sense, the eschatological assertions of Paul to the Thessalonians, and what we are to say dogmalically now, knows no ontological difference. What 1 Thessalonians makes known theologically, we too say now - that although the grace of Christ is experienced immanently, it remains a future we can articulate only as that which is 'impenetrable' and 'uncontrollable' (cf. 1 Thess 5:2).18 For both the Thessalonian Christians, and for us now, the truth remains the same: eschatology is the forward expansion of the grace of Christ experienced in the present. Anything that is said eschatologically, at any time, is always born from the experience of Christ's grace and 'derives from the assertion about the salvific action of God in his grace on actual man' $^{\prime}{ }^{19}$ For Peter Phan, therefore, this is the centre of Rahner's argument, ${ }^{20}$ that the Sitze im Leben of all eschatological statements are essenlially the same, "the experience of God's salvific action on vurselves in Christ.21 Thus, at all times, in all places, the future is experienced as 'a reality which has achicved power to influence the present itself and in that sense has become the real. 22

At this early stage, Rahner's hermencutics provide us with three maximns. There is, first, a reminder that the task of interpreting Biblical eschatology is one of 'almost unmanageable complexity', testified not least by Rahner's intricate argument. ${ }^{23}$ The right to be heard speaking about the future of God, and our roles within that futturc, is earned by slow, patient labow. Secondly, there is in Rahner's hermeneutic a recognition of the contribution of historical-critical pursuits, but a location of these purstits within a theological framework which casts such pursuits aright, as well as pushing us to realise that the hermeneutics of eschatological assertions is 'a properly theological task to be carried out on the basis of the analogia fidei." 24 "Thirdly, there is a potent reminder that any eschatological assertions we see fit to make now remain

\footnotetext{
${ }^{17}$ Rahner nowhere meritions the Thessalonian Christians - we are building this assertion out of what he does say aboul the hermeneutics of eschatological assertions.

${ }^{18}$ Rahner, 'The Hermeneutics', 333.

${ }^{19}$ Rahner, 'The Hermeneutics', 338 .

${ }^{20}$ Phan, 1988, 71.

${ }^{21}$ Rahner, 'The Homeneutics', 336 (emphasis original). So Phan, 1988, 71, provides us with a neat sumimary o[ Rahner's thesis, "Whatever the Chistians know about their future fulfilment, they know it fiom the fulfilment that has already occurred in Christ.'

${ }^{22}$ Rahner, 'The Question of the Future', 184.

${ }^{23}$ Phan, 1988, 68 .

${ }^{24}$ Phan, 1988, 68.
} 
always as 'a retrospective interpretation of the old, not a new and better assertion which replaces the old.'25 In this sense we are not engaged in the task of replacing or duplicating the eschatology of the Patl of 1 Thessalonians, but participatitg in the movement of the same experience of eschatological grace.

One of the implications for our endeavour is that to speak on the basis of 1 Thessalonians' eschatology is not an exercise in retrieval. It is not an exercise in arguing for what Paul meant or even primarily what he intended when he wrote this or that. It is rather an exercise of disceming what can be said on the basis of this text of our futures, from our location in the eschatological present that is Christ's grace experienced as salvific presence. It is a thinking alongside and with Paul, a level of thinking sustained by the same grace of Christ which unites Paul and all subsequent interpreters.

The focus of our study will be on the worlds of understanding the apostle Paul points us towards, offering this exploration as an amplification of the realities to which the revelation of 1 Thessalonians points. The intention of our reading of 1 Thessalonians, mindful of Rahner's hermeneutical manifesto, is less to dwell on putative circumstances lying behind the lexl, but more on the new realilies proposed and sustained by attention to the text itself.

The concentration on the revelatory subject matter of the text - on the realities which the text encourages the theologian to begin to understand - is a frequent theme in Karl Rahner. Although he does not explicitly say that he is talking about 1 Thessalonians 4:13f, there can be little doubt what sections of Paul's literary output are in his mind when he writes,

'We do not need to be afraid that we will depart from the teaching of St Paul, if we do nol rack our brains too much about how the dead will hear the sound of the archangel's trumpet and how this harmonises with the sending out of the many angels or with the resuscitating voice of the Lord himself, which we are told about in his own eschatological discourse. We can regard this text as an

\footnotetext{
${ }^{25}$ Ralmer, 'The Hermeneutics', 345 .
} 
image and yet be terrified by what it truly means to convey both to the people of these days and to us today: the all-powerfulness of God over the dead, who even when dead cannot escape him; indeed, we may conjecture that God in his omnipotence, just because he is all-powerful and never in danger of being rivalled, will give even the created forces of the world a share in the work of the consummation of the dead into the life beyond all death.' 26

Mindful of Rahner's protestations, and of theology's requirement to be open to the mystery of God's salvific will, we will seek to keep distinct the symbol from the symbolised, the mode of signification from that which is wltimately being signified. Our driving interest will be to explore the potency of the images contained within 1 Thessalonians, images pointing to God's all-powerful hold over death.

\footnotetext{
${ }^{26}$ Rahner, 'The Resurrection of the Body', 210.
} 


\section{(2) Paul's contribution}

\subsection{The integrity of Paul's contribution}

A large part of what Christianity has to say about death, and the dead and their futures is to be found in the deceptively simple creed of 1 Thessalonians 4:14, 'we believe that Jests died and rose. The One who died and rose, as the One who converted the world to God, is the 'living' God's (1:9) response of grace to the reality of death as a power. The simplicity of the creed - that 'Jesus died and rose' - should not mask the profound truth held within the God who united Jests' death to his resturrection. Just as the One who died 'for us' (5:10) died 'for our sins' (1 Cor 15:3) so too is this is a saving power only made manifest by his resurrected state, 'If Christ has not been raised...you are still in your sins.' (1 Cor 15:17).27 In rising, or as Paul characteristically prefers, being risen from the dead by God (1:10), the saving work of Christ is now lifted tp into the expanse of God, and his saving work on the cross is given ultimate significance and vindication through the resurrection. ${ }^{28}$

Before any theological advances are attempted it is necessary to recognise that in Paul's creed-like statements - 'Jesus died and rose' (4:14) and Jesus 'died for us' (5:10) - Biblical scholars sec evidence of pre-existing Christian formulae, primordial examples of a Christian creed, ${ }^{29}$ Ernst Käsemann, in his work on the death of Jesus in Paul's thought, dismisses such inherited liturgical tradition as inadequate guides to Paul's radical, cross-centred thought-world. ${ }^{30}$ For Käsemann, such irhlerited, ecclesiallymbound statements offer little help in understanding the radical nature of Jesuls' death on al cross. Although Käsematu is amongst the most important Pauline theologians of last century and one is reluctant to treat his work with anything bul the highest respect there is much to be said for Charles Cousar's opinion that we should work on the assumption that Paul is responsible for the final form of his letters. The citing of a liturgical formula makes it a piece of his own argument' ${ }^{31}$ As

\footnotetext{
${ }^{27}$ An effective unity of salvation noted by Cousar, 1990, 96; Hengel, 1981, 70; Hooker, 1978, 477-8; Käsemann, 1969, 42 .

${ }^{28}$ cf. Rahner, 1978, 266, "The death of Jesus is such that by ils very nature it is subsumed into the resurrcetion. It is a death into the resurrection.'

${ }^{29}$ e.g. Hengel, 1981, 37; Best, 1972, 186-7.

30 e.g. Käsemann, 1969, 37, 45. Bultmann, 1965, 296, is equally dismissive.

${ }^{31}$ Cousar, 1990, 17. So also Hultgren, 1987, 49, says of Paul's use of the kerygmatic formula 'for us' that, 'its frequency in Paul's letters indicates that the formula became a part of the apostle's own proclamation.'
} 
Patal is both receiver and moulder of the tradilion in which he stands, the kerygnatic statements that Jesus 'died and rose', or that Jesus 'died for us' cannot be so easily relegated as Käsemanur would like.

Paul's theological contribution, it is correctly noted by New Testament scholars, is not an ontological Christology. ${ }^{32}$ Paul's prime contribution is that of a functional Christology, and it is to that voice we must listen in our wider discussion of the salvific work of Christ made known in his death 'for us'. Correspondingly, in 1 Thessalonians Paul spends little time on the means by which Christ saves and is more concerned with the effects of this death 'for us'. Jesus 'died for us, so that whether we

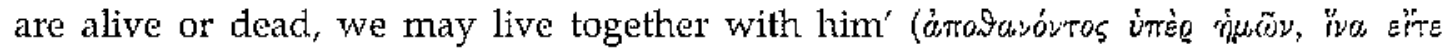

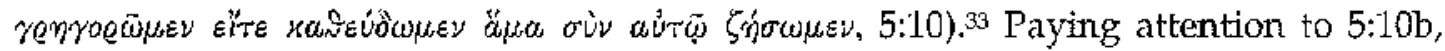
Kenneth Grayston is no doubt correct to assert that the closest parallel in Patu's thought is Romans $14: 9,34$

'For to this end Christ died and lived again, so that he might be Lord of both the dead and the living.'

\footnotetext{
${ }^{32}$ Hooker, 1993, 87; Cousnr, 1990, 49; Hultgren, 1987, 65; Longenecker, 1985 inter alios. Within this debate however, some, like Fee, 2002; Hultgren, 1987, 65, argue that at hough Paul did not set out the ontological implications, he nevertheless did adhere to Christ's pre-existence. The key verses for such scholars are 1 Cor 8:6; 2 Cor 8:9 and Phil 2:6-7. Whilst alware of concerns raised by 'critical' Biblical scholars, we should not forget or neglect tluat Nicene Christology was believed by the Fathers to be completely faithful to the witness of the New Testament. For a recent defence of Nicene readings of the Now Testament see Yeago, 1997.

${ }^{33}$ The ambiguity of the Greek here does not add to the lucidity of Paul's metaphors in I Thess S:1-11.

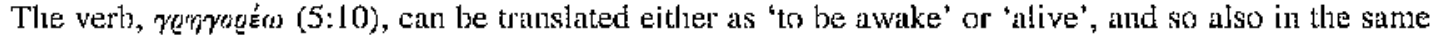
verse, the verb, $x u s q \varepsilon \dot{y} \delta \omega$, can be translated as 'to be asleep' or 'dead'. In the previous verses Paul had counselled against the danger of being found sleeping when Jesus returns (5:6). The Thessalonian Christians must be found 'sober and alert'. It is unlikely however that Paul is still deploying this metaphor in this verse. Paul is not incorporaling the futures of the 'awake' and the dead, but in a reversion back to the concerns of 1 Thessalonians 4:13-18, is encouraging the Thessalonians that both the dead and the living have an assured future 'together' and with Christ.

Those who dissent from the majority opinion that $x a n$ 'svं $\partial \omega \mu z \nu$ is another euphernisin for 'death' as in 1 Thess 4:13 (routuojai), note that these are not the same verbs. Edgar, 1979, exhaustively lists other New Testament uses of xa.9rúbo and argues that as with those examples here it must also refer to a lack of vigilance. But failing to understand that the central message of 1 Thessalonians is Christ's defeat of the community-rending effects of death (hence the emphasis in 1 Thess $4: 15,17$ on the corporate aspect of the resurrection) Edgar is distracted by the mixed metaphors, and does not see that no matter how these two verbs are used in the rest of the New Testament, here they are being used to return to Paul's message of consolation - your loved ones who have died have not been cast out of the sphere of Christ's power. Moreover, Edgar pays scntt attention to the movement of 5:9-10: Jesus died 'for us' so that whether 'we are dead or alive we might live with him.' See Jurgensen, 1994, 100.

${ }^{34}$ Grayston, 1990, 14.16.
} 
In dying 'for us', and vanquishing death's sting through his resurrection, Christ now stands as Lord of a community of believers incorporating both the dead and the living. Whether we are now dead or alive we are with the One who has died and been raised from the dead by God. ${ }^{3}$

\subsection{The saving work of God in Christ}

If Jesus died 'for' $11 \mathrm{~s}^{\prime}$ is of any abiding soteriological worth it is a claim that inseparably involves God in the work of Jesus. ${ }^{36}$ Jesus saves because what Jesus is doing 'for $1 \mathrm{~s}^{\prime}$ is bound up with what God is doing 'for us', in the form of the One who is wholly human and wholly divine without confusion and with complete unity. ${ }^{37}$ Although we have conceded that Paul is not concerned with the ontological interests of Patristic Christology, I 'Thessalonians does point, in a primordial form, to a strong salvific relationship inherent between God and Christ.

At points in the letter Paul can use the terms 'God' and 'Christ' almost interchangeably, as if referring to the same person. Just as much as the 'church of the Thessalurians' is 'in God the Father' $(1: 1), 38$ so too are the Christian communities in Judea 'churches of God in Christ Jesus' (2:14). ${ }^{99}$ Cyril of Alexandria, for whom the unity between God and Christ could hardly be over-cmphasised, ${ }^{40}$ likewise noted approvingly that in 1 Thessalonians $1: 8 ; 2: 1-2 ; 2: 9$ and $2: 13$ Paul unquestioningly alternates between 'gospel of God' and 'gospel of Christ'. For Cyril, this stood as

\footnotetext{
${ }^{35}$ Sclsweizer, 1967, 3. See also Kramer, 1966, 192-3 for discussion of Rom 14:7-9.

${ }^{36}$ This senlence condenses all that was achicved in the anti-Arian disputations. For the Arians the Son of God enjoyed only an external relationship with the Father. The achicvement of Athamasius and subsequent Eastern Fathers was to stress how the internal relationship between the Father and the Son, both enjoying the very same properties and essence, was crucial to the soteriological claims of Christianity. In Orthodox theology it is the Word's assumption of humanity, of which the death on the cross is one outworking, that is the prime nover of salvation. See Tainer, 2001, 28-9; 'lorrance, 1990, 228-9; Thunberg, 1985, 65-6.

${ }^{37}$ Tanner, 2001, 21, 'a human being's dying on the cross is not saving unless this is also God's dying; and God's dying does not save us (it is not even possible) unless God does so as a human being.' (emphasis original). So also Torrance, 1988b, 149.

${ }^{38}$ Here we favour the incorporative sense of the dative $\left(\varepsilon^{\prime} \nu 9 \varepsilon \tilde{\omega} \pi a \tau e^{i}\right)$ favoured by those like Donfried, 1996,393 , as opposed to the instrumental sense argucd for by Bcst, 1972, 62 .

${ }^{39}$ It stould be noted that this is a verse whose authenticity is disputed, and the literature is predictably voluminous. For an argument is favour of Pauline authorship, sce Hurd, 1986, and for an influential study which opposes Paulite authorship, see Pcarson, 1971. Still, 1999, 24-45, provides a good overview of the debate, whilst arguing for Pauline authenticity. Those commentators who dispute

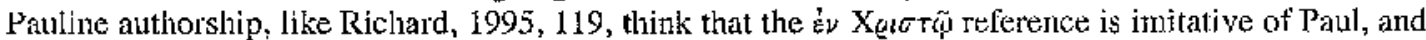
translate the word order, 'which, through Jesus Christ, exist in Judea'. Wanamaker, 1990, 112, (who supports Pauline authorship), concurs with our translation as does Moule, 1977, 56, inter alios.

${ }^{40}$ For Cyril's Christological principles see McGuckin, J.A., 1994, 175-226; Dratsellas, 1975.
} 
apostolic proof that Christ is called God, and hence that for Paul Jesus is wholly divine,

'Does he nol clearly refer to his preaching of Christ as the 'gospel of God' and 'the word of God?'41

Similiarly, just as Iater in the letter Paul talks of the dead 'in Christ' (4:16), so too is this a relationship initially enjoyed by God. Paul alludes to the self-expression of God it the person of Christ when he writes of 'the will of God in Christ Jesus' (5:18). This is an intrigtingly early example of a strikingly high claim for the person of Jesuts.42 It is then quite logical that Paul expects God to execute his saving work 'though Jesus' $(4: 14),{ }^{43}$ for Jesus is God's very 'Son' (1:10).

God and Jesus are united partners in the work of salvation, a feature of this letter which, we have seen, was recognised from the earliest times. Athanasius, writing on 1 Thessalonians 3:11 in the midst of his Anti-Arian discourse, asserts that here Paul is keen to emphasise the unity of the Father and Son. In using the third person singular - zatevinvat - rather than the third person plural,44 Paul indicates that there are not two people working the grace to direcl Paul to the Thessalonians, but the Father working through the Son,

'For onc and the same grace is from the Father in the Son, as the light of the sun and of the radiance is one, and as the sun's illumination is effected through the radiance' ${ }^{4.5}$

This involvement of God within Jesus' saving work is developed in other parts of the Pauline corpus. As Charles Cousar demonstrates, the prepositional phrase found in 1

\footnotetext{
${ }^{41}$ Cyrit of Alexandria, 'Scholia on the Incarnation of the only Begotten',\$ 21-23. Translated in McGuckin, 1994, 294-335 (314).

42 Similar examples of this claim are not common in the New Testament. See Rom 6:11; 8:39; Eph 4:32; Phil 3:14.

${ }^{43}$ 'The closest parallel to this is Rom 5:21, "just as sin excreised dominion in death, so grace might also exercise dominion through justilication leading to eternal life through Jesus Christ our Lord.'

${ }^{44} \mathrm{Karev}$ Qivar is in the third person singular of the aurist optative. If Paul hid wished to say 'May they direct' he would have used the form, katevisivass. Best, 1972, 147, correctly notes the impossibility of rendering this in English without considerable awkwardness, "May himself our God and liather and our Lord Jesus direct.' A contemporary Orthodox Biblical scholar, Tarazi, 1982, 130, states on this verse, "This is a clear proof, that, in Paul's mind, God the Father' and the Lord Jesus are the one source of the same action, though the one is not the other.'

${ }^{45}$ Athanasius, 'Four Discourses Aguinst the Arians'; III.xxv. 1 I.
} 
Thessalonians 5:10 (ume $\dot{\eta} \mu(\tilde{\omega} \nu)$ is echoed in Romans 5:6-8, tú a passage whose theme is that the work and person of Jesus is the means by which God reveals his love. ${ }^{17}$ As Cousar notes, and we can rightly expand, Romans 5:8 displays a 'striking closeness' of activity between God and Christ, 48 a reciprocity brought out by the mirroring in these verses of the 'for us' phrase. God proves or demonstrates ( $\sigma u v i \sigma \tau \eta \sigma u$ ) his love 'for us' by the death of Christ who died 'for us'. God reveals in Christ his love for the 'ungodly' (Rom 5:6), and Christ's act on the cross is a revelation of the rature and being of God. Thus Jesus' act refers beyond itself to the salvific will and desire of God himself. This reciprocity between God and his Son is in accord with Galatians 1:4, where Christ is the One 'who gave himself for (imè) our sins to deliver us Irom the present evil age, according to the will of God our Father.' Precisely because God's will works itself 'through Jesus' (4:14) Paul can understand Jesus' death both as his own giving (Gal 2:20) and the giving of God (Rom 8:32).

It therefore seems legitimate to read Paul's statement that Jesus 'died for us' as essentially a claim about God's involvement in the person of Jesus' death. The claim that this One, Jestus, died 'for us' is thus only intelligible insofar as we establish what it means to say that God was involved in this death. To be sure, this is where I'aul's contribution needs to be supplemented: although God in Christ is Saviour for Paul he spends little time on how these two natures meet and interrelate.42

The problems surrounding the attestation of Jesus' divinity all the way to his death are legion. If, in the Word becoming incarnate, 'all that is the Father's, is the Son's' ${ }^{50}$ how can the 'living' God (1:9) take on that which is not God: mortality and the appearance of eternal extinction?51 How can the immutable God apparently take on the things of temporality: birth and life's extinction, death?52 How can God retain the saving capacity - as God - within the act which is, on first reading, the clothing in the arch-contradiction of God Himself: death. Such condundra are related to the wider

\footnotetext{
40 Cousar, 1990, 44.

47 'The phrase 'for' us' is located twice in Rom 5:8 by means of 'eis خjuärs'.

${ }^{48}$ Cousar, $1990,45$.

49 So also Hooker, 1993, 86.

50 Athanasius, 'Four Discourses against the Arians', III.xxiii.4.

${ }^{51}$ Cyril of Alcxandria, On the Uhity of Christ, 61.

$\$ 2$ In relation to these questions see the discussion of 'l'heodore of Mopsuestia and Nestorianism in Meyendorff, 1987, 8. Kenoticism is another response to the difficulties of talking ol God dying on the cross. In this perspective there is a risk of Jesus being only human on the cross, not full of the life of the divine: see Tanner, 2001, 10; Meyendorff, 1987, 14-15.
} 
task of incarnational theology, of explaining how God remains God in bodily form, whilst managing to take on enough humanity in ordex to bring humanity back into commumion with divinity. ${ }^{53}$

In the midst of this debate our theological interests are relatively specific (though they necessarily feed off the debate which these ancient questions and discussions have fostered): in seeking a theological reading of 1 Thessalonians, what sense does it make to say that Jesus 'died for t1s'? It is in pursuit of answering that question, to which we now turn, that we will progress to a deeper understanding of 1 Thessalonians 4:14.

53 'Torrance, 1988b, 152, "if the humanity of Christ were in any way deficient, all that he is said to have done in offering himself in sacrifice 'for our sakes'.... would be quite meaningless." 


\section{(3) God's grace in dying 'for us'}

Beginning to unravel the theological potential of a text which speaks of Jesus dying

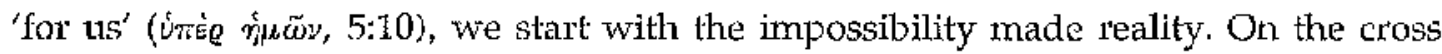
the incarnate deity takes on all that is against his nature: death and extinction. Jesus' death is 'for us' precisely because as the Word incarnate Jesus is not death, and his taking on that which is not his is an expression of God's salvific desire to live in renewed communion with humanity. ${ }^{54}$ 'This death is experienced and believed in as a death 'for us', the mysterious act by which God remains God even in taking on death, and in so doing extends his love to every aspect of our humanily in order to bring it back to life in the living God.55

Such preliminary reflections remind us that the primordial creed, Jesus died 'for us' is an attestation that Jesus' death was a death that spilled out of its own limited frame of reference, and in its precise character as death, is relevant 'for us' ${ }^{56}$ 'That in Christ, the human and divine natures meet as God's initiative to restore creation is an exposilion of the nascent Christian realisation that the One who 'died and rose' is the One who was acting 'for 'us'. The God who acted in and through Christ, died 'for 'us' and hence incorporated creation within his embrace, in a manner typical of his love,

\footnotetext{
'what unites God and us men is that He does not will to be God without us, that He creates us rather to share with us....that $\mathrm{He}$ does not allow His history to be His and ours ours, but causes them to take place as a common listory. 57
}

At its most elementary the pro nobis claims of Christian faith are attestations in a Cod who desires to live in relationship with creation, even if that means restoring the

\footnotetext{
${ }^{54}$ cf. 'Tanner, $2001,15$.

55 A clearly Eastern Christian motif, for which see Meyendorft, 1987, $27-8$.

${ }^{56}$ So Stuhlmacher, 1986, 174, stresses that the early Christian tradition of defining Jesus' death as 'for us $^{2}$ was aut altempl to see in the hortor of the cross God's saving will, 'God not only had turned the evil of Jesus' death into its opposite by the resurrection, but also had effected salvation already in the death of Jesus, precisely lhough the vicurious sacrifice of the life of his son. Thus Jesus' death is part of God's saving work and is indissolubly connected with the resurrection.'

${ }^{57}$ CV IVI $1, \%$
} 
relationship which our $\sin$ has rent astunder. ${ }^{38}$ God is a creator irrepressibly involved with his creation.

The Christian confession of faith is that all the darkness of death has been taken on fully and freely assumed into the light that is the life of the incarnate God. But more, Christ's death is a death whose effects are 'for us', it is a death which makes sense of all our deaths precisely because he has died 'for all' (2 Cor 5:15). Jesus' death in time, as 'the Lord of time', 59 therefore becomes a death for all time, for all who seek to understand more of death's nature. The death of Christ, whilst at one lcvel representing the death of a brigand on a Roman cross, is a death which is, lotally independent from our claims on the cross, a death 'for us', a death which appropriated in faith can begin the process of unravelling the divine potential of our deaths (and lives). Jesus' death on a cross enables our deaths to be taken up into the life of the triune God. The creed that Christ 'died for us' is an exposition that the whole of humanity's being, even unto death, has been taken up into the loving selfexpression of God made known in Christ. ${ }^{\text {ho }}$

The views presented in the New Testament, and in subsequent theological reflection on exactly how Jesus' death is redemptive are notoriously pluriform, and a whole plethora of images have been and are deployed in order to make sense of the saving significance of the death of Jesus.61 This dazzling kaleidoscope of perspectives (which we will attempt to bring into some kind of collective focts) is itself evidence of the numerous ways in which Christian comumunities have perceived themselves to be redeemed. In the same way that we cannot restrict eschatology by making it a predictive exercise, so too we cannot expect to talk of any one way in which Jesus is Saviour. Working with a number of salvific images, we will ensure that we do not box in the mystery of the salvation made known by God in Christ, but remain open to the scope of redemption broadcast in Jesus' death 'for us'.

\footnotetext{
${ }^{58} \mathrm{CD}$ IV/1, 53-4. See also Barth, 1961, 46, "God's deity is thus no prison in which He can exist only in and for Iimself. It is rather IIis freedom to be in and for Iimself but also with and for us, to assert but also to sacrifiee Himiself, to be wholly exalted but also complately humble'.

${ }^{59} \mathrm{CD}$ III/2, 466 .

${ }^{60} \mathrm{cf}$. Rahner, 'Thoughts on the Possibility of Belief 'Foday', 13.

${ }^{61}$ See McIntyre, 1992; Hultgren, 1987; Turner, 1952; Aulến, 1931.
} 
Keen to retain the integrity of the different conversants we plan to engage with, we propose three intertwined and muttually interpretative ways in which to interpret and understand the formula, Jesus died 'for us'. First, Jesus' death 'for us' is a demonstration of God's radically complete grace (\$ 3.1). In this sense, the priority of God's loving manifestation in Christ is absolute and undisputed, an important reminder in the face of the theology we will later develop. Sccond, Jesus' death discloses God's radical love (\$ 3.2), manifested in the 'us' for whom Christ died. Third, the death of the Son igniles God's radical exchange made known in the Incarnate Son (\$ 3.3). It is this final image of redemption which most adequately prepares us for our reading of the resurrection of the dead $(\$ 4)$. It is important to recall that none of these models are complete in themselves, but standing logether they grapple with the mystery of the One whose death is 'for us'.

\subsection{The radically complete grace of God}

In dying 'for t1s' God in Christ does for us what we could not do for ourselves unaided. Jesus dying 'for us' is gift and grace on our behalf, as something already fully complete before we even begin our appronch of faith.62 Taking on death 'for us', so to absorb il into the life and source of the One who 'died and rose', death's power of eternal extinction is defeated once and for all. Whilst giving himself over to death completely God never stops being God in this act of expunging death's dominion. ${ }^{63}$ That God takes on all that is not God, whilst never ceasing to be God, is part of the mystery of the claim that Jesus died 'for us', namely that this One's death is of benefit to all humanity. In this sense, dying 'for us', taking our death into the life of the living God, is a claim for what is done in the human Jesus, that in the saving cross 'sin and death have been assumed by the One, the Word, who cannot be conquered by them.'64

Christ's death is an act whose salvific potency and communicative will is radically independent of any claims which we might lay on it by way of imposition. In this way, Jesus' death is a prevenient act of God through which he expresses his eternal

\footnotetext{
62 Torrance, $1988 \mathrm{~b}, 158$, atoning reconciliation must be understood as having taken place within the personal being of Jesus Christ as the onc Mediator between God and man, and thus within the ontological roots and actual condition of the human and creaturely existence which he assumed in order to save.'

${ }^{63} C D$ IV/ $1,185$.

64 'I'anner, 2001, 29.
} 
desire that we live in fellowship with him. As such God initiates this process, taking on humanity to the point of death, so allowing all humanity to share in the life of the divine. Christ's death as an act of grace is, by definition, an act independent of any claims humanity may wish to claim for it by means of restriction. God's word, at work in us (2:13), is thus a word of cruciform service directed to t1s, an offence against any model which 'sees grace as serving my needs as I define them.'65

Dying 'for us' is an act of God in Jesus' complete freedom, a freedom to be God even when dead in the human form of his Son. The salvific potence of this death 'for us' is so complete that we need not think our faith can complement it or boost its power,

\begin{abstract}
'Whatever may happen in consequence of the fact that Jesus Christ is for us cannot add to it. It can only be the consequence of that which has taken place fully in Him and needs no completion. ${ }^{\prime} 66$
\end{abstract}

Jesus' full identification with us in our deaths - made known in the One who weeps at the death of his friend I azarts and who appears to shrink from his own death in Gethsemane - is the way in which this death is 'for us'.6\% Jesus travels 'with us' in grief, the fear of death, 68 and even death itself. Weeping at the death of Lazartus, and seeming to shrink from his own death, it is necessary to state that waless,

\footnotetext{
${ }^{65}$ Williams, R., 1982, 80 (emphasis original).

${ }^{66} \mathrm{CD}$ IV/1, 230.

${ }^{67}$ CD IV/1, 229. cf. Cyril of Alexandria, Commentary on the Gospel Accorting to St. John, vil (on In 1 1:36-7), "And the Jews thought that He wept on account of the death of Lazarus, but He wept out of compassion for all humanity, not bewaling Lazarus only, but understanding that which happens to all, that the whole of humanity is made subject to death, having fustly fallen under so great a penalty.'

${ }^{68}$ The Eastern Fathers put much emphasis on the salvific significance of Jesus' prayer in the Garden of Gethsemane. See the discussion of Cyril of Alexindria in Smith, J.W., 2002, 473-6, and in relation to Jotn Damascene in Lossky, 1976, 146-8, bhn Damascene was, of course, a successor of Maximus the Confessor's insistence that Christ had two wills (dyothelitism as opposed to monothelitismi) - a human and a divine will - and that these wills were demonstrated in the Garden of Gethsemane. In Maximus' exegesis of the Gethsemane drama Christ hands over his human will - expressed by his fear of death over to the divine will, thus realising a harmony between the two wills. Through the salvific concert of these two wills in the person of Christ - climaxing on the cross - the fear of death that is natura! to our post-lapsarian selves is itself redeemed. See 'Ad Thalassium 21', transiated in On the Cosmic Mystery of .Jesus Christ, 109-13, "For he put off the principalities and powers at the moment of his death on the cross, when he remained impervious to his sufferings, and what is more, manifested the (natural human) feat of death, thereby driving from our nature the passion associated with pain. Man's will, out of cowardice, tends away from suffering, and man, against bis own will, remains atterly dominated by the fear of death, and, in his desire to live, clings to his slavery to pleasure.' (112). The importance of insisting for the operation of the two wills in Christ is an extension of Gregory of Nazianzus' antiAppolinarian teaching that 'what IIe [Christ] has not assumed He has not healed; but that which is
} 
'Te had felt dread, human nature could not have been free from dread; unless $\mathrm{He}$ had experienced grief, there could never have been any deliverance from grief....The affections of His flesh were aroused, not that they might have the upper hand as they do indeed in $\mathrm{t5}$, but in order that when aroused they might be thoroughly subdued by the power of the Word dwelling in the flesh, the nature of man thus undergoing a change for the better.' 69

In this sense the raising of Lazarus is part of the progressive unfolding of what is revealed in the course of Jesus' ministry: Jesus is taking all the things of humanity and lifting them into the life of the 'living' God. ${ }^{70}$ God, in Christ, is doing what he is always doing: giving to humanity the gifts of his divine life. ${ }^{72}$ What is revealed in the One who died 'for us' is crucially (literally) linked to the One who throughout his ministry rebelled against death's dominion: in assuming all that is death, Christ, as the One whose humanity is united to the living Word, transforms death into life..$^{22}$ In the One who raised Lazarus from the dead, and who died 'for us', death itself becomes something 'for us'. In dying 'for us', gifling to th the pattern of his life which had trampled down death, Jesus crosses over death's boundary 'for us' so that we may live in his company 'forever' (4:17).

united to His Godheud is atso saved.' ('St Gregory Nazianzen's Letter to Cledonius', translated in McGuckin, J.A., 1994, 390-9 (393)). So 'Opuscule 7', translated in Louth, 1996, 180-91, 'there is also one will and another will, the divine and the human, and therefore two wills....For it appears that the same as man, who is also God by nature, wills in accordance with the economy that the cup pass, and in this he typifies what is human, as the wise Cyril taught us, so that he might take away all shrinking from death from our nature, and steel and arouse it to a brave assault against it, I mean against death.' (188). See also 'Opuscule 3' translated in Louth, 1996, 193-98, and also 'Opuscule 6' translated in On the Cosmic Mystery of Christ, 173-6. For discussion of the issues involved here see Blowers, 2001, 366-70; Louth, 1996, 56-62; Yengo, 1996, 191 18.39; Thunllerg, 1985, 12-20, 23-4. Interesting connections could be made here, if space allowed, with Philippians 2:5-11, which talks of Jesus being of the very 'form of God' (Plit 2:5), though bccoming 'obcdicnt to the point of dealh' (Phil 2:8).

In connection with the Gethsemane incident, see also the exegesis of Barth in $C D$ IV/1, 265-73, 'If there is anything whitch brings out clearly this simple "for us" as the content of the Gospel, then it is this aspect of the event in Gethsenane [when Jesus prayed alone], in which the act of God in Jesus Christ had absolutely nothing to conespond to it in the existence of those who believe in Him. They could not watch with him even one hour. He alone watched and prayed in their place.' (268).

${ }^{69}$ Cyril of Alexandria, Commentary on the Gospel Accorting to St. Join, VIII (on In 12:28). See atso Athanasius, 'Four Discourses', [H.xxix.56-7, where he counters the charge of those who regard Jcsus' display of fear at his own death as a proof against his divinity.

${ }^{70}$ For this strand of Alexandrian Christology, that in the human ministry of Jesus God is progressively gifting to humanity the goodness of God himself, see Tanner, 2001, 27; Torrance, 1988b, 162; Young, 1971; Turner, 1952, 49-53.

${ }^{71}$ Gregory of Nyssa, 'An $\Lambda$ ddress on Religious Instruction', $\$ 12$.

${ }^{72} \mathrm{CD} \mathrm{ML} / 2,600$. 
God in Christ is doing more than joining us in fellowship in our deaths, for he is also decisively communicating the properties of God to death itself, enabling his death to be truly 'for $\mathrm{us}^{\prime} .{ }^{73} \mathrm{All}$ of death is totally transfigured by the grace of God in Christ. Death, previously an ugly manifestation of our sin, becomes the means by which God reveals his abundant grace; what to us is empty and bereft of hope is transformed, through God's fullness, into a signal of hope. ${ }^{74}$

The difference that Christ's death makes, and the reason why it is 'for us', is that this voluntary death was 'caused not by the necessity of the fallen nature, but by the freedom of the Redeeming Love.'75 As the Son of the 'living God' (1:9) - he simply did not have to die, but in choosing to dic, and so save humanity through his death, he gains power over death itself, and he offers this power out to all. At all times this death 'for 11s' was a death over which Christ had complete dominion, something that is not true for us, 'the death did not happen because of the birth, but on the contrary the birth was accepted for the sake of the death. ${ }^{76}$ Throughuut, God in Christ remained in complete dominion over death - his victory over death's force was (and will be) assured. ${ }^{7}$

In the figure of Christ our salvation is thus radically complete; for those willing to hear the whole of our salvation is to be found in the saving work of Christ.78 God is thus both subject and object, actor and author, reconciler and reconciled in this divine drama of redemption, a drama in whose outworking we become players by receiving that which has already been achieved by God in Christ: 'reconciliation' and an 'overflowing of grace' (Rom 5:11, 17). ${ }^{79}$ This is to read seriously the sense in which Jesus died 'for us'.

\footnotetext{
${ }^{77}$ Rahner, $1961,70$.

${ }^{74}$ cf. Rahner, 1961, 78.

${ }^{75}$ Hlorovsky, $1951,25$.

${ }^{76}$ Gregory of Nyssa, The Catechetical Ortation, \$ 32. Cited in Danićlou, 1962, 17 with slightly different translation. See also Floroviky, 1953, 16.

${ }^{77}$ Athanasius, 'On the Incarnation', $\$ 26$, 'It was not from any natural weakness of the Word that dwelt in it that the body had died, but in order that in it death might be done away by the power of the Saviour.'

${ }^{74}$ Comm. John 3:16. Cited in Hart, 1989, 71 .

79 ef. Bultrnam, 1965, 286.
} 


\subsection{The radical love of God}

In dying 'for tus' God reveals his nature to be loving, precisely because he died 'for us.' Expcricncing death in itself, Christ endured the full intramundane and extramundane horrors of death. He knows what it was to die in pain, fear and loneliness. Jesus knows what it is to approach death with fear, 'Father, if you are willing, remove this cup from $\mathrm{me}^{\prime}$ ( $\mathrm{Lk} 22: 42$ ) and in the darkness which seems to negate the possibility of God's presence, 'My God, my God, why have you forsaken me?' (Mk 15:34). Jesus' death is a death that is apparently no stranger to the opacity of God's presence. So complete is God in Jesus' identification with creation that he experiences death in the extremities of its metaphysical horrors. God's love is revealed in the radical cxtension into this 'far country' and death is quite literally the farthest he could have gone for us." God's love makes known the advent of God into the very depths of humanity's darkness, his healing desire that, in all ils ambiguities, he would make our condition his own. ${ }^{31}$

God's love in dying 'for us' is all the more astorishing given that this was a place that should have been ours. In this sense, Jesus' death 'for tus' was a death in our place. ${ }^{\text {sz }}$ Properly considering the 'us' for whom Christ died, it is hard to escape reading 1 Thessalonians 5:10 as conveying a sense of vicarious representation, a 'on behalf of' or an 'in place of' action. ${ }^{83}$ God in Christ was one with us in every sense - apart from our

\footnotetext{
${ }^{80}$ For the original use of the phrnse, 'far country' see CD IV/1, 157-210.

${ }^{81}$ Gregory of Nazianzus, Oration XXX.v. Sce Winslow, 1979.

${ }^{82}$ This vicarious aspect to Christ's death is popularly seen to be antithetical to Eastern Patristic thought. Tanner, 2001, 87, is it contemporary spokesperson for this way of thinking, dismissing vicarious understanding of Jesus' death with the alternative view that, 'God saves through unity with the Son in Christ.' Tanner is perhaps a little hasty. One of the weaker points of Tanner's book is that there is little evidence of a wiestle with the polyphony of Scriptural testimony, something which lay at the heart of the Patristic endeavour. Not only is the idea of Christ's substitutionary death a prominent theme in Paul (e.g. Gal 3:13), but there is also considerable evidence for its popularity with the Eastern Fathers. Sce Blanchette, 1964, who strongly argues for its importance in Cyril of Alexandria's theology. Koen,

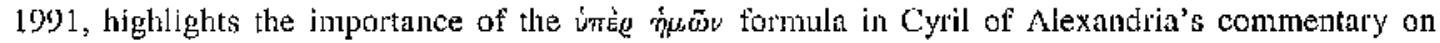
Joln's Gospel. See, for example, Cyril of Alexandria, Conunentary on the Gospel According to St.

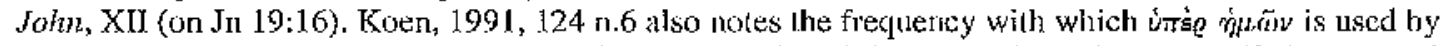
Greek Fathers in a substitionary sense. Athanasius deployed the phrase in such a way 150 times; Basil 70 times; Gregory of Nyssa 70 times; and Gregory of Nazianzus some 35 times. Koen demonstrates how Cyril maintained a synthesis between Christ's person and his work, such that his substitutionary role on the cross is understood from the perspective of the nature of Christ's person. Thus his death 'for IIs' is understond from the perspective of his person, of who Christ was and is. For this Eastern Father, at least, while there was no sense of an Anselmian 'debt' to be paid by min to God, this is not to suppose that Christ does not play out a sacrificial role 'for us'.
}

${ }^{83}$ Cousar, 1990, 55-6. 
sin - but nevertheless 'Christ died for our sins' (1 Cor 15:3). ${ }^{84}$ Not waiting for us, God in Christ died for us as sinners (Rom 5:6-8), and so shows that he goes before us and acts preveniently in releasing us from death's hold 85 Christ dies 'for us' so that humanity may re-capture the sense of communion with the divine lost due to sin. Being perfect, and unblemished by sin, in Christ God reconciles the world to himself (2 Cor 5:19). ${ }^{86}$ God in Christ, taking tp a substitionary role in our salvation, therefore has universal implications, and it is for this reason that Paul can say that Christ 'died for all' (2 Cor 5:14), ${ }^{87}$ This was something that was ours to do but we were doomed to futility because 'a sinner cannot justify a sinner. ${ }^{\prime g 8}$ In this sense, Anselm was correct to remind us that only a God-man could save us, for only God can defeal dealh, and only one who is fully htman can die in solidarity with us. Karl Barth, writing on the use of the prepositions $\dot{a} \nu \tau i$, imè (the preposition used in 1 Thessalonians 5:10) and reoi in the New Testament treatment of Jesus' death comments that,

'They cannot be understood if we to not see that in general these prepositions speak of a place which ought to be ours, that we ought to have taken this place, that we have been taken from it, that it is occupied by another, that this other acts in this place as only Je can, in our catuse and interest ${ }^{\prime}{ }^{89}$

While some recent thought has shyed away from 'substitutionary' undexstandings of God's love on the cross, Paul's thought, it would seeri, supposes a strong relationship between Jesus' death and the reality of sin in the world. Driven by the love of Christ (2 Cor 5:14) God in Christ's death is vitally linked to the reality of $\sin$ in the world, and the need for those sins to be slain decisively, for 'the death he died, he died to sin, once for all' (Rom 6:10).

\footnotetext{
${ }^{84}$ Iengel, 1981, 36, proposes that wherever we see inte ius $\bar{w}$ ', we should read 'for the forgiveness of our sins.'

${ }^{85}$ cf. Barth, 1956, 3.

${ }^{36}$ For Aulen, 1931, this is the 'classic' view of the atonement, that 'God is at once the atithor and the object of the reconciliution; He is reconciled in the act of reconciling the world to Himself.' (72).

${ }^{87}$ cf. Dunn, 1991, 51.

${ }^{88}$ Anselm of Canterbury, "Why God Became Menn', I.xxiti; cf. CD IV/1, 25l. Anselm's penal view of Christ's death is critiqued in strong terms by Lossky, 'Redemption and Deification' in Lossky, 1974, 97-110. See 'I'urner, 1952, 98-101, for the reasons why Anselm's 'transactionalist' understanding of Jesus' death proved so popular in Latin thought.

${ }^{89} C D$ IV/1, 230. This understanding of a substitutionaly or vicarious death, conveyed by the preposition inze, is also supported by Cousar, 1990, 56.
} 
The Son of God taking on death is expressive of God's love because it is a totally gratuitous act - other than for our salvation, there is and was no need for Jesus to die. ${ }^{90}$ Jcsus was completely sinless. Jesus enjoys fullsomely the gifts of life within the fellowship of the Trinity already, and he was in no need to die and rise again. Jesus, in his very being, has never stopped enjoying the fruits of immortality. Jesus took on the $\sin$ of humanity as his own, and in so dying for our sins his death is 'for us'.21 To be sure, we must avoid the excesses of sacrificial understandings of Jesus' death. I-His salvific death is 'for us' chiefly because he is the Word become flesh, not because he is an innocent offering made to God. ${ }^{y / 2}$ At all times Jests' acts were an expression from within the economic will and love of God Iimself - there is no point at which we can say 'this was Jesus' and 'this was God', for at every stage, 'Christ is of God' (Xonròs

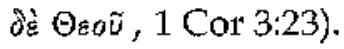

What Christ did, in recalling us from death to life, was an act of love towards humanity, an act from which he had to gain nothing, ${ }^{23}$ other than our continuing communion within the life of God. His willingness to die for us, and so make possible the gift of life with him $(5: 10)$, is purely the desire of love. It was God in Christ who lovingly took on the horror of death on the cross (healing the world from within, not from without as Barth says), ${ }^{44}$ who died 'for us' precisely so that with the power of sin slain we may enjoy communion with God once more. Dying vicariously 'for us', God in Christ extending out to us, became our $\sin$ so that we might become the rightcousness of God (2 Cor 5:21). Thus in 2 Corinthians 5:21 Paul uses this same phrase - imè $\dot{\eta} u \tilde{\omega} \nu$ - in a passage where it is promised that what God was doing for the world in the reconciling ministry of Christ was 'not counting their trespasses'.95 The vicarious aspect of Jesus' death, in Paul's thought connected with sin, seems hard to deny when one considers the intimate connection Paul constructs between Christ's

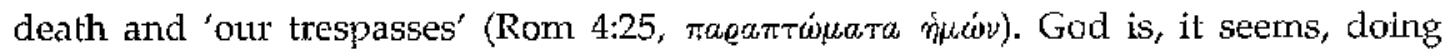

\footnotetext{
${ }^{90}$ Florovsky, 1953, 16.
}

פCD IV/1, 232-5.

92 St Cyril of Alexandria, On the Unity of Chrisi, 59-60. So Torrance, 1988b, 168, states that the Nicene Fathers used terms such as sacrifice 'to refer', not to any external transaction betwocn God and mankind carried out by Christ, but to what look place within the union of divine and human natures in the incarnate Son of God.'

${ }^{93}$ On this paragraph see Gregory of Nyssa, 'An Address on Religious Instruction', 32.

${ }^{94} \mathrm{CD}$ IV/1, 237.

${ }^{95}$ Cousar, 1990, 80. Cousar suggests that Romnns 4:7-8 (where Ps $32: 2$ is cited) is likcly echoing what 2 Cor 5:19 is claining, 'Blessed are those whose iniquities are forgiven, and whose sins are covered blessed is the man against whom the Lord will not reckon his sin.' 
something in economic unity with Christ, which deals with our sins through his Son's death.

The emphasis is properly put on the radical and gratuitous freedom of God's love, the love which wills to bring the fullness of the divine life into ever closer communion with humanity. Vocabulary must be found to talk of our creaturely dependence - made known in the creator who dies 'for $u^{r}$ - whilst avoiding a perspective which lalks more of the wretchedness of humanily than the gratuitous grace of God. The love of God, God being transcendent, is simply not dependent on the depravily of man. What is revealed in the God who dics 'for us' is precisely this overwhelmingly loving will. The New Testament scholar, Ennst Käsemann, articulates crisply then what Christ's death represents in Patll's thought,

'What he is establishing is our incapacity to achieve salvation for ourselves. Salvation is always open to us without our doing anything for it - as a gift according to Rom 3:24, and as Rom 5:6ff. stresses with immense emotion, before we have fulfilled the will of God. It is only the love of our creator which saves. ${ }^{\prime 96}$

\subsection{The radical exchange of God}

Eastern Christianity has traditionally been wary of the excesses of vicarious understandings of Jesus' death and keen to retain the unity of God in Christ; penal understandings of Jesus' death 'for us' have often been suspected of subordinating Christ's role to that of an intermediary. ${ }^{97}$ In Orthodoxy the emphasis is put on the death which the living God in Christ defeated, and not on the sin for which Christ 'paid' a debt. $\%$ Christ is Saviour because God in Christ assumes every part of our

\footnotetext{
${ }^{96}$ Käsemann, 1969, 39.

${ }^{97}$ Meyendorff, 1975, 24. The actual picture is less polarised than stercotypes might suggest. In whe West, Augustine can lapse into a style that hints at deification: 'On the Trinity', IV.ii, 'By joining therefore to us the likeness of His humanity, He took away the unlikeness of our urrighteousness; and by being made partaker of our mortality, He made us partakers of His divinity.' Likewise, John Daxnascene, 'Exposition of the Orthodox Faith', III.xxvii, discloses a discernible juridical slant in an Eastern thinker.

${ }^{98}$ For the Greek Fathers the problem with man was nol so much sin, but his inescapable death, which

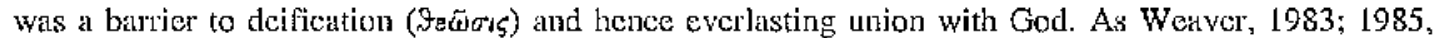
demonstrates this was rooted in divergent Latin and Greek interpretations of Romans 5:12. For the Latin Fathers, beginning with Tertullian and Cyprian, and consolidated with Augustinc, humanity's predicament for which we needed redemption was inherited guilt, for which death was a penalty. This trend continues: see Weinandy, 1993, whose title, $h$ the Likeness of Sinful Flesh: An Essay on the
} 
humanity, from birth to death. ${ }^{99}$ The saving capacity of the cross is that it is a witness to 'God alongside and for us in the flesh.' ${ }^{100}$ For the Eastern Fathers (and hence for Orthodox theology, the cross is salvific, because what happens there is illustrative of the whole of the Word's incarned existence: the salvific unily of divinity and humanity. ${ }^{101}$ John Breck, a contemporary Orthodox theologian, is not being glib when he insists that, "the Greek fathers were more concened with who died on the cross than with the question of why that form of death was necessary.'102

The virtues of this approach are that it is able to clain that death is now wrapped up within the identity of the Cluristian God. God has experienced death, his solidarity with humanity extending even to our darkest hour. Athanasius refers to this two-fold saving power of God in Christ when he referred to 'two marvels' taking place on the cross. In the meeting of God in Christ with all humanity the death of all was accomplished in the Lord's body', and so too 'death and corruption were wholly done away by reason of the Word that was united with it.' 103

In this final exploration of Jesus' death 'for' t1s' we will seek something of a synthesis. Whilst incorporating elements of vicarious readings of Jesus' death, readings which take seriously who exactly is this ' $1 s^{\prime}$ ' for whom Jesus died, we will explore more decply the death represented by God in flesh participating in all the things of humanity and so redeeming them by lifting us up into his life.

We begin by repeating ourseives. In dying, Jesus takes on that which is not his, death. Moreover Jesus himself has nothing to gain from his death, rather the gain is all on our sidc. The language of 'interchange' has its uses here, ${ }^{104}$ although it has its limitations: it is the grace of God, acting throtigh Jesus, that always remains in a state of primacy. The grace of God in Christ overwhelms any retribttive schemes we might

Mumanity of Christ indicates what this Roman Catholic scholar thinks is most important about the assumed humanity of Christ.

${ }^{90}$ See 'The Orthodox Doctrine of Salvation and Its Implications for Christian Diakonia in the World' in Stăniloae, 1980, 181-212.

${ }^{100}$ Cyril of Alexandria, 'Cyril's Letter to the Monks of Egypt', $\$ 26$. Translated in McGuckin, J.A., $1994,245-261(261)$.

101 'The Orthodox Doctrine of Salvation' in Starnilone, 1980, 181-212 (198).

102 Breck, 1992, 115.

1013 Athanasius, 'On the Inverumtion': $\$ 20$.

I04 A conmon strand in early Pntristic thought. See, for example, Athanasius, 'Ad Adelphium', \$ 4. Amongst Pauline scholars, Ilooker, 1981; 1978; 1971, advocates the notion of 'interchange' in relation to Pauline sotcriology. 
imagine God works with - that just might still be alluded to in the term 'interchange' - for Christ is a gift which confounds any system in which we might dare to conceptualise and contain God.

Romans 5:12-21 is the capital text for understanding just how the grace of God topples over the scales of just retribution. The abundance of grace is God's response to the piling up of our 'many trespasses' (Rom 5:16), for the grace of God

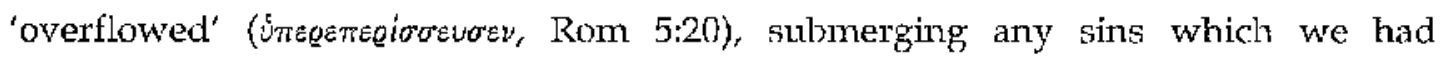
increased. Romans 5:12-21 therefore charts the inevitability to God's victory of grace, the same inevitability, we might add, which God holds over all the dead. Although

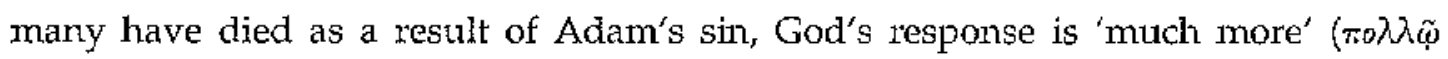

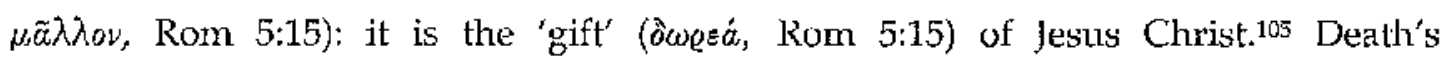
temporary victory over the man 'in Adam' is as nothing compared to the victory over death declared in the man Jesus Christ. It is no longer death that reigns, the domirion once enjoyed by death has been responded to by that which is 'much more' (Rom 5:17): the aburdance of grace and the gift of righteousness, our reception of which allows us to rcign in life 'through the one man Jesus Christ' (Rom 5:17). This exchange powered by God's abundant grace is dramatic - it is no longer death that holds dominion over us, but we ourselves enjoy dominion in tife, all of this being possible only through Jesus Christ. Barth articulates well the force of this passage when he writes, 'It is the slaves of death that are to become the lords of life.'106 To articulate it even more appropriately, we might recall that we only reign in life through the victory of Christ, itself a sign that it is now grace which reigns (Rom 5:21). The sphere of Christ's grace allows no space for death to be Lord, for there is only one Lord whose works are assured ultimate victory, 'whether we are alive or dead' (1 Thess 5:10).

This grace of God which tramples down death does not work on a predictable path of reward and retribution, for it is a grace that is always extending out to justify the ungodly' (Rom 4:5), precisely because in dying 'for us' Jesus dies for the ungodly (Rom 5:6). Such grace will always deflate our attempts to contain it in any one system or understanding. In refusing to be 'boxed in', the outworking of God's grace

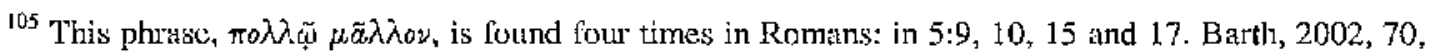
rightly satys of this expression that it, 'means as a rule that he [Paul] wishes to make a distinction of, so to speak, catastrophic proportions'.

${ }^{106}$ Barth, 1956, 22.
} 
wriggles free of the legalistic mindset of the Anselmian perspective. ${ }^{107}$ More importantly, it affords little space for anything resembling a reciprocal process of exchange.108 'The 'reconciling exchange' which God makes known in Christ cannot but be unequal, ${ }^{109}$ because the promise of our incorporation within Christ's incorruption is made possible by the incorruptible Christ being fully united to all the corruption of humanity. There is little reciprocal in such grace.

Jesus does indeed communicate to us the life which resides in him, but there is nothing we bring to this exchange, at least not yet. It is God who is in charge of this process of salvation - he is the stbject of the action, and it is sin-laden humanity which is the object of God's activity. Romans 3:25 is often cited as a strong example of humanity bcing acted upon by the will of God's loving exchange. It is God who

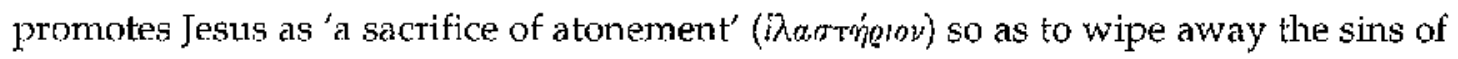
humanity.110 So too in Romans 8:32 is God the subject - it is he who did not withhold

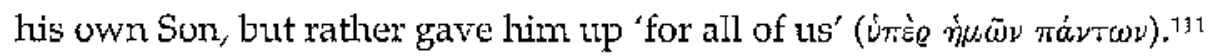

On the cross Jesus takes our place, taking on what is not his, but ours, and in so freeing us from the sting of death, he promises us eternal life. This is the exchange alluded to in I Thessalonians 5:10.112 Jesus takes on our death, he dies 'for us', and because the One who died is the One who 'died and rose', our death passes throtgh the promise of the resurrection. Jests takes on our death 'for us' and gives us in exchange the promise that he has initiated a process whose assured future is that 'we might come to life with him.'113 We are transferred from death to life, precisely throwgh the One who died 'for us'. He takes on our death, and we take on his life, insofar as we live and die 'in Christ' (4:16). Participation and substitution - so often the playgrotund for theological tussles - are, in Patl's mind, closely related. It is by Christ's radical substitution that we participate in his risen life. This is the same kind

${ }^{107}$ So Aulén, 1931, 107, 'the Atonement is not accomplished by strict fulfilment of the demands of justice, but in spite of them; God is not, indeed, unrighteous, but He transcends the order of justice.'

${ }^{108}$ Hooker, 1978, 462, 'the giving is all on one side, and the taking on the other:'

${ }^{106}$ See 'lorrance, 1975, for discussion of this motif in Eastern Patristic thought.

${ }^{110}$ Dunn, 1991, 49; Young, 1975, 72. Also Hooker, 1978, 465, 467.

IIt Although Paul is convinced that Christ is no honourable man whose death is of some general benefit, but rather that God is working in and through Christ's death, he should not be read in an overly-enthusiastic Nicene sense. Hengel, 1981, 35, notes passagcs where Jesus is the activc subject of his own death: Gal $1: 4: 2: 20$.

${ }_{112}$ cf. Hooker, $1978,462-3$.

113 This translation of 1 Thess 5:10b is favoured by l'annehill, 1967, 133-4. The Aorist Subjunctive, $\zeta$ no $\sigma \omega \varepsilon \varepsilon v$, is translated in an inceptive sense, to convey the punctiliar sense of the aorist tense. 
of unequal exchange we saw at work in Romans 5:12-21. Just as the 'free gift' (xágr taken on by Christ 'for us' is completely flattened by the grace of life eternal with Christ $(4: 17 ; 5 ; 10)$. God, who communicates his will of salvation through Jesus Christ (5:9), makes known through his Son's death and resurrection, and the subsequent lives called to participate in this triumph, that he is the God of the living,

\begin{abstract}
'The essential point is that Christ died in order that He might bestow upon us Iis life, which is eternal and unending. Again, there is nothing strange in the fact that he now dectares that we live with Chuist, since having entered by faith into the kingdom of Christ, we are passing from death into life. ${ }^{\prime 11}$
\end{abstract}

The 'for us' formula is thus only properly understood via a perspective which sees Jesus initiating a process where he takes on that which is not his, and gifts to us in exchange that which we did not deserve. He takes on that which is not his - death - so that we might enjoy that which was not ours - life with God in Christ. This notion of reconciling exchange runs throughout the Pauline corpus.115 Jesus saves because he takes on 'the likeness of sinful flesh' (Rom 8:3), precisely because like the humanity he was identifying with he was 'born of a woman' (Gal 4:4). Jesus' death for us is part of his representative saving capacity - Christ's death achieves something 'for all' ( 2 Cor 5:14). Taking on our poverty, Jesus bestows us his riches (2 Cor 8:9). He is born under the law, so that all those under the law might enjoy sonship, just as he is God's Son (Gal 4:4-5).116 So too, in Galatiuns 3:13, Christ becoming a curse 'for us' (vinè müüy) is the means by which we are redeemed from the curse of the law we laboured under. In this divine economy of exchange, the setting aside of out sins plays a vital part. We

\footnotetext{
${ }^{114}$ Comn. 1 Thess. 5: 10.

115 In an important essay, Käsemann, 1971, makes the role of reconciliation in Paul's thought completely subsidiary to what he sees as the centre of Paul's thought: justification. Kassemann's modus operandi is similar to his 1969 essay (discussed in $\S 2.1$ ), and he relegates Rom 5:10f and 2 Cor 5:1821 to 'tradition that was handed down to him.' (Käsemann, 1971, 52). Hence such verses are deemed unreliable indicators of Paul's thought, not least because they represent the first attempts to domesticate (i.e. insert into the language of the church) the gospel. Kuisemunn's disingenuify is astounding. Whilst inveighing against those who would use the text 'is a quarry for modern theories' (59), he constructs a canon within a canon, a project driven by his theology that, 'The church itself is always the greatest obstacle to its own mission.' (60). For further critiques of Käsemann's position in this essay see Martin, 1981, 75-9; Fitzmyer, 1975, 162-7.

${ }^{116}$ Dunn, 1991, 4\%.
} 
become the righteousness of God, through the One who acts for God, but equally by means of the setting aside of our sins. ${ }^{117}$

Taking on all our sin is a vital part of Jesus' divine act of taking on what is not his. ${ }^{118}$ This transfer is well expressed in 2 Corinthians 5:21. 'For us' (imè müuv) the One who knows no sin is made sin so that 'in him' (év aúrộ) we might become the 'righteousness of God'. The sinless One, by dying for us, thus exchanges all the gifts of God to those who have strayed from God's goodness. These verses, from 2 Corinthians 5:18-21, point to the importance of the setting aside of our sin, and yet also point to what God is doing in Christ, so that we might enjoy the gifls (i.e. the righteousness) of God. There is a salvific 'will of God in Clirist Jesus' (1 Thess 5:18) which transactionalist notions of Jesus' death should not let us ignore. Rightly, both New Testament scholars and systematic theologians warn against over-stressing 'substitution' in Paul's thought, at the expense of God's abundant sharing of his gifts. 119

Before we talk of substitution, or sacrifice, or judgement - a plurality which Christian tradition has discemed in the 'for us' formula - we must talk of that which the death of Christ ultimately reveals: the radical act of the divine towards and for us. What the death of Jesus makes known is that God desires us, he wants to live in peace with us (1:1), and he wills that we are delivered from eternal destruction (1:9-10; 5:9). All this he achieves in the unity of his salvific love in and through his Son, and it is this dynamic of divine action that is, prior to everything else, experienced in the Saviour who died 'for ns',

'The decisive thing is not that I-Te has suffered what we ought to have suffered so that we do not have to suffer it, the destruction to which we have fallen victim by our guilt, and therefore the punishment which we deserve. This is true, of course. But it is true

\footnotetext{
${ }^{117}$ Cousar, 1990, 80.

118 This strong Greek Patristic motif stands opposed to the tendency of Latin Patristics to promote the idea of the Son of God assuming a human nature untninted by original sin, and hence free from the divine judgement. See Torrance, 1990, 203. The important emphasis of these more Eastern developments is that it is precisely in being judged 'for us' that Jesus' death is 'for us'.

${ }^{119}$ See Dalferth, 1991, 320, for a systematic theologian, and Hooker, 1978, for a Biblical scholar. Calvin powerfully outlines the 'wondrous exchange' which God reveals in Christ: Inst. IV.xvii.2; Comm. 2 Cor: $5: 21$.
} 
only as it derives from the decisive thing that in the suffering and death of Jesus Christ it has come to pass that in His awn person IIe has made an end of us sinners and therefore of sin itself by going to death as the One who took our place as sinners...God has done this in the passion of Jesus Christ. For this reason the divine judgement in which the Judge was judged, and therefore the passion of Jesus Christ, is as such the divine action of atonement which has taken place for $u s .{ }^{\prime} 120$

Jesus' death 'for us' is a making known the radical love and self-surrender of God. God, swallowing up our death of destruction offers us in its place a death of hope, a death in which it is possible for us 'to recognise the law of our own dying, in so far as in his death the invisible God becomes for us visible. ${ }^{\prime 21}$ The notion of a reconciling exchange relies upon Christ giving us something. He gives his death to us, precisely by laking on our death, so that the story of his death may become the story of each and every one who believe his death to be 'for us', and therefore 'for me' (Gal 2:20), Recognising that on the cross Jesus plays some kind of substitionary role need not be read in an exclusive sense - the wondrous exchange of God in Christ involves is in God's grace at every stage of Jcsus ${ }^{r}$ healing ministry. Our story now becomes part of his story, his story of what he does with death becomes indispensable for understanding what our death will become in our story. Dying 'for us' death and life are now fused together - in our lives we walk around with his life-giving death in us (2 Cor 4:10) and in our deaths we are filled with the very life of God himself.122 Orientated towards the future, his death is 'for us', because we see in his death what will become 'for us' in our death. ${ }^{123}$ More than dying 'for us' in a substitionary sense, in rising from this very same death, God assures us of Jesus' exemplary new humanity. ${ }^{124}$ The reconciling exchange is set to continue.

\footnotetext{
${ }^{120}$ CD IV/1, 253-5 (mphasis adeled). Cl. Hunsinger, 2000, 136-7.

121 Barth, 1933a, 160 (emphasis original).

$122 \mathrm{cf}$. Sherrard, 1998, 181, "instead of realising that we are involved at every moment in a living-dying existence in which life and death are two taces of an identical reality, we regard them as contraries".

${ }^{123}$ cf. Dalterth, $1991,308,315$.

${ }^{124}$ Bonhoeffer, 1966, 48 .
} 


\section{(4) Eschatological participation and promise in 1 Thessalonians}

\subsection{Theological prolegomena}

For Paul, a large part of salvation is in the future, a future in which we mutst place our hope. ${ }^{195}$ The reconciliation which we enjoy through Jesus' death on the cross is a completed action which lies in the past, "we were reconcilea to God through the death

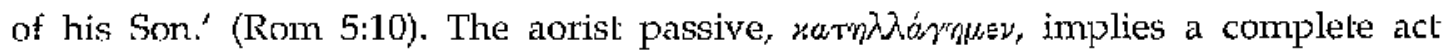
whose effects are now complete. Allied to this reconciliation which we 'now' (vïn, Rom 5:11) enjoy with God is our future salvation, a salvation from 'the wrath of God' (Rom 5:9) which will be delivered to us 'by his life' (Rom 5:10).126 In Patl's thought we are already reconciled to God by his cross, but oux future salvation is something we wait for with hope, the hope which 'does not disappoint us' (Rom 5:5). Salvation, for Paul, is tinged with eschatological expectation - it is the life of the Risen One who will save us from the coming wrath. Traces of what Paul plots in greater detail in Romans 5 can be scen in 1 Thessalonians. 1 Thessalonians 1:10 claims that it is precisely as the One who has risen from the dead that Jesus will rescue us from the 'approaching'

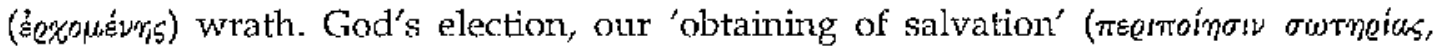
5:9) from this impending wrath, is made possible 'through (dic่) our Lord Jesus Christ' $(5: 9)$.

Patl articulates here the basis of the hope, not enjoyed by the rest (4:13), and the reason for the injunction that the Thessalonians - and all those who grieve subsequently - are to adopt a distinctive approach to death. It is worth reminding ourselves of the grammatical movement of Paul's pastorally directed logic in 4:14. Our conviction of the protasis - that Jesus has known death and known what it is to rise from the realm of death - leads to the comfort of the apodosis: that God, through Jesus, will bring with him those who are sleeping (xomnisivtas). The pattern of Jesus' life - the One who has died and risen, is the guarantor, the pledge of our fultures. The resurrection that was his, will be ours also. Just as God has done with Jesus in raising him from the dead, so God, through Jesus, will do to those who believe. Panl is quite consistent in this belief right to his last letter', 'he who raised Christ from the dead will give life to your mortal bodies also' (Rom 8:11). The Christian hope, hoping against

\footnotetext{
125 cf. Sanders, $1977,449$.

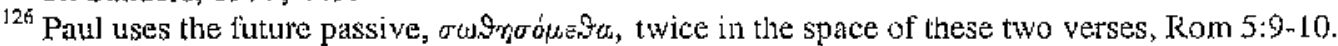


futility, is that the whole of the dead, 'spirit and soul and body' (5:23), will arise to meet the retarning Saviour. ${ }^{127}$

For Pat1l, Jestus' bodily resurrection and our bodily resturrection are linked in a grace of conformily. ${ }^{128}$ Paul's revelation was that in Christ, and with his resurrection, it was possible to see evidence of a 'new creation' (2 Cor 5:17). Correspondingly Paul counsels the exrant Corinthian Christians to be aware of what they are doing with their bodies, for, as he implies, the same power which raised Jesus, will raise them up too, 'God raised the Lord and will also raise tis by his power.' (1 Cor 6:14). For Pat1, indeed, the name of Christ is synonymous with the 'power of God' (Xerotoy gravi Surum, 1 Cor 1:24). To believe in the narrative of the One who has 'died' and then 'rose' is belief that the world is now wrapped up in 'the power of his resurrection'

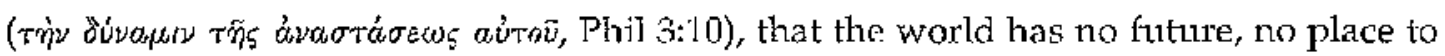
relurn to, other than God. In Christ, the world now has a new boundary: not the day of our death, but the 'day of the Lord' (5:2) when the world and God's triumphant grace will gloriously converge. ${ }^{120}$

Pat1 realised that to talk of the principle of the resturrection working its way through the world is to enter the realm of images and symbols, rather than the hope of literal representation. Paul likens Christ as the 'first fruits' of those who have fallen asleep (1 Cor 15:20), with his return being compared to a harvest ( 1 Cor 15:23), when those who

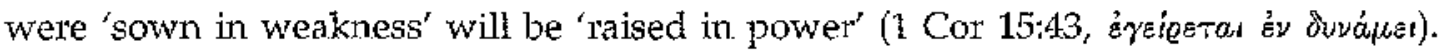
Like many of the Fathers grappling with the mystery of the world's transfiguration in Christ, Gregory of Nyssa possessed a catena of metaphors which echoed the Pauline conception of a world under grip by a new power,

\footnotetext{
${ }^{127}$ There simply is not space to deal with the debate concerning the relationship between bodily identity and personal iderslity, nor is it as pertinent to 1 Thessalonians as it clearly is in 1 Corinthians 15. It is clear, however, that the Pauline stress on bodily restrrection incorporates the idea of the holistic salvation of humanity, as Lohfink, 1977, 35, recognises, 'Resurrection means, in fact, that the whole human being reaches God, the whole luman being, with all his experiences and all his past...all the words he has spoken and all the deeds he has done.' The least glib response to this knotty debate is that 'in Christ' our whole identitics are perlectly preserved until our bodily resurrection when who we are in the light of Christ shall be fully revealed. 'Nobody Knows Who I am Till Judgenent Morning', in Williams, R., 2000a, 276-89, is at highly pregnant essay in this regard.

${ }^{128}$ See Rom 8:11; 2 Cor 4:14; 1 Cor 6:14; Phil 3:10f.

${ }^{129}$ cf. Batth, 2002, 18 .
} 
'as fire that lies in wood hidden below the surface is often unobserved by the senses of those who see, or even touch it, but is manifest when it blazes up, so too, at His death... He who, because He is the Lord of glory, despised that which is shame among men, having concealed, as il were, the flame of His life in His bodily nature, by the dispensation of $\mathrm{F}$ is death, kindled and inflamed it once more by the power of I-lis own Godhead, fostering into life that which had been brought to death, having infused with the infinity of His divine power that humble first-fruits of our nature', ${ }^{130}$

Just as in Christ's human life, God's very divinity was united to our fleshly humanily, so in our continuing fellowship with Christ, through the Spirit, we await our flaming up, the manifestation of what we are now becoming in Christ, despite the visible persistence of death. The much-vaunted cosmic dimension and scope of the Fathers of the East is easily matched by the Pauline confidence that for those 'in Christ, there is a new creation: everything old has passed away; see everything has become new!' (2. $\operatorname{Cor} 5: 17)$,
'now, as then, $\mathrm{He}$ is equally in us.... Then He mingled Himself with our nature, in order that by this mingling with the Divine Being our nature might become divine, being delivered from death...For His return from death becomes to this race of mortals the beginning of the return to immortal life. ${ }^{\prime 131}$

Just as the Word was hid in Christ's flesh, so in our bodies there is an already present participation with Christ's risen flesh, and the tritumph of this outworking will be, just as Jesus' was, at our bodily resurrection. Participating in the power of Christ's risen, triumphant life, our assurance is that 'we will certainly be united with him in a resturrection like his.' (Rom 6:5). In another of Gregory's suggestive images, just as air pushed down into water always escapes back to the surface in a bubble, and as Jesus descending to his death rushed back to the surface (life), so in our deaths, like the air

\footnotetext{
120 Gregory of Nyssa, 'Against Ennomius', V.5.

${ }^{131}$ Gregory of Nyssa, The Catechetical Oration, \$25.
} 
always caught tup within the rising bubble, our bodily resurrection, in conformity with his, is assured. ${ }^{132}$

To turn to one of Cyril of Alexandria's (376-444 CE) favoured images, Christ's resurrected life inserted within the weakness of our bodies is,

'as if one took a glowing ember and thrust it into a large pile of straw in order to preserve the vital nucleus of the fire. In the same way our Lord Jesus Christ hides away life within us by means of his own flesh, and inserts immortality into us, like some vital nucleus that destroys every trace of corruption in us. ${ }^{\prime 133}$

In the imagery so favoured by Thomas, just as through Jesus' touch of the leper the healing power of his divinity is communicated, ${ }^{134}$ so through our communion with the 'fire' of Jesus' resurrected life is its inherent heat communicated to us. ${ }^{135}$

Reminding ourselves of the discussion at the beginning of this chapter, the assurance of oux future resurrection is only ever confirmed and built twp out of the present experience of grace. ${ }^{136}$ Giving voice to our eschatological future, in this perspective, is not here a deductive exexcise, but an exercise in tracing the consequences of the life we lead now through the graced experience 'in Christ' (4:16).137 The 'in Christ' formula (explored in \$ 4.4) reminds us that for Paul salvation is all about being pulled into a relationship with the Saviour himsclf, ${ }^{138}$ a relationship which charts the believer's whole future. In dying 'for us' - in all the depths of its substitutionary and reconciling exchange value - Christ initiated a salvific process where God reaches out to us, and we return to God by participating, through the aid of the Spirit, in the life of the risen

\footnotetext{
${ }^{132}$ Gregory of Nyssa, The Catechetical Oration, \$ 25. Cf. Tanner, 2001, 117.

${ }^{133}$ Cyril of Alexandria, 'Commentary on John 6:54', translated in Russell, 2000, 117-8. Cyril believed that Christ's life was thrust into us by means of the Eucharist: Chadwick, 1951.

These Patristic images revenl an important Christological principle, highly relevant to talking of the resurrection of the dead. Whilst words will always stumble in the attcmpt to explain or describe the effects of the Incarnate God, immges such as these can aid in illustrating Paul's witness in 1 Thessatonians 4:14. For the use of imagery in Cyril of Alexandria's Christology see McKinion, 2000, esp. 181-226; McGuckin. J.A., 1994, 196-8; Wickhant, 1982.

${ }^{134}$ Lectio IV.11.95.

135 cf. ST 3 a q.56 a.1 re.

${ }^{136}$ Rahner, 'The Hermenentics', 342.

${ }^{137}$ Tatuler, 2001, 104.

$13 \mathrm{~s}$ c.' Hart, 1989, 70.
} 
Christ. Leading our lives out 'in Christ' God now offers us the chance to live in the power of his risen life. For those of faith there is a new imperative at work, the need to consider ourselves 'dead to sin and alive to God in Cluist Jesus' (Rom 6:11).

We have now examined Paul's claim that Jesus 'died for us' in its rich multivocity, climaxing with the image of the reconciling exchange (\$ 3.3). This reconciling exchange which is set to continue will be known most fully with the resurection of the dead, a doctrine for which images offer us the best hope of exploring. Consolidating our reading of 1 Thessalonians, we will turn now to a number of images within 1 Thessalonians which point to the resurrection of the dead: a comminity transfigured and transformed ( $\$ 4.2$ ); images of light and prayer within 1 Thessalonians (\$ 4.3); the image of the 'dead in Christ' (\$ 4.4); the 'sleeping' Christians (\$ 4.5); and the image of the parousia itself (\$ 4.6).

\subsection{Transfiguration and transformation in 1 Thessalonians}

Paul's revelation in 1 Thessalonians can be concisely put: in Christ what it is to live and what it is to die is now totally reconfigured. The believer in Christ is distinguished by the triad of faith, love and hope, 'We always give thanks to God for all of you, constantly mentioning you in our prayers, remembering before our God and Father your work of faith and labour of love (ád $\left.\gamma^{\prime} \pi \gamma_{\zeta}\right)$ and steadfastness of hope in our Lord Jesus Christ.' (1:2-3). To enter into the community called together by God is to live out a faith making itself known through its own generative power (1:8); it is to live in a community where there is an abundance of sacrificial love extending to one another and all $(3: 12 ; 4: 9-10 ; 5: 13,15)$; and it is to live wilh a hope that looks for the consurnmation of this world in the will of God $(1: 10 ; 2: 12,19 ; 3: 13 ; 4: 13-18 ; 5: 4)$. Squeezing this triad of faith, love and hope into two items of metaphorical armour, ${ }^{139}$ Paul refers to Christian life as equipped with 'a breastplate of faith and love and a helmet, the hope of salvation.' (5:8). For Thomas such spiritual armoury safeguards our present wellbeing - 'the life of the Spirit in us ... Christ, through whom the soul lives' - and ensures our salvation, 'the goal which we hope to attain. "1t0 This 'hope of

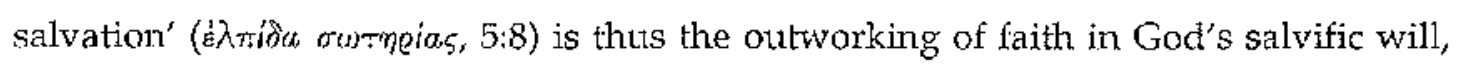

\footnotetext{
${ }^{139}$ Possibly based on Isa 59:17. See Best, 1972, 213-4.

'A0 Lectio V.I.120; Duffy, 1969, 46.
} 


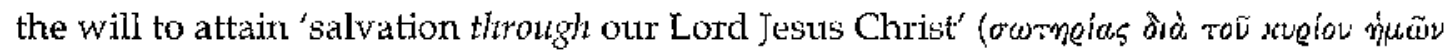
'I

In an elementary sense, it is faith which adopts what is made known by God in Christ: the source of humanity's conversion to God. It is faith in the work of the One who has died and risen that calis forth a new obedience to love, and a hope that our lutures are 'already seized and determined.'141

Paul's redrawing of what it is to live and to die, is an image cast around Christ. The most important identity the Thessalonian Christians have is their location within the saving purposes of God, an especially prominent theme in this epistle. This is a location which totally relativises any grief the Thessalonians manifest over the supposed gulf that now separates the living from the dead. The Thessalonian Christians are part of a church which is 'in God the Father and the Lord Jesus Christ' (1:1). The salvific 'word of God' has a power which has worked through the Thessalonians, 'in you who believe' (2:13). In this verse Paul reveals everything which is happening pertaining to faith as the work of God and his word. ${ }^{142}$ Despite all the tribulations, which Paul knows they have suffered, they still 'stand firm in the Lord' (3:8). Just as Patul and his co-workers encourage them 'in the Lord Jesus' $(4: 1)$, so likewise are those caring for them, doing so 'in the Lord' (5:12).

As Cyril of Alexandria noted (\$ 2.2), there is a reciprocity between being 'in Christ' and being 'in God', for the 'gospel of God' (2:9) is the 'gospel of Christ' (3:2). The very source of the church itsclf is the work of 'God the T'ather and the Lord Jesus Christ' (1:1) interlocked.143 This revealing of God's will in the person of Jesus is indicated towards the end of the Ietter where Paul talks of 'the will of God in Christ Jesus' (9Eov

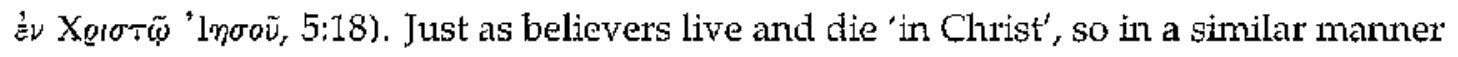
God expresses his will 'in Christ'. This is a relationship proper to God, but is ours insofar as we are gathered into the éxx noia and brought into faith by the inspiration

\footnotetext{
${ }^{141} C D$ IV/1, 116. See also Rahner, 'Jesus' Resurtection', 18, 'We therefore can and Inust say: bectusc' Jesus is risen, $I$ believe in and hope for my resurrection.' (emphasis original).

142 cf. Barth, 2002, 73-4, on a very similar construction in Phil 2:13.

${ }^{143}$ Tarazi, 1982, 27.
} 
of the Hoty Spirit, ${ }^{144}$ The salvific narrative, heralded by the God who 'raised Jesus from the dead' (1:10) is thus only made part of the individual believer's lives by the activily of the Holy Spiril,

'it is not the impelling force of the flesh or the promptings of their own nature that will make men ready and willing to obey God. Rather, this is the work of the Spirit of God. ${ }^{145}$

For Paul the Holy Spirit is a gift of God to the Thessalonians (4:8). It is the same Holy Spirit which Patul and his fellow missionaries have received (1:5), and gives them the strength that comes from being 'in $\operatorname{God}^{\prime}(2: 2)$. It is this Spirit that enables the Thessalonians, even in the midst of persecution, to receive God's word 'with joy of

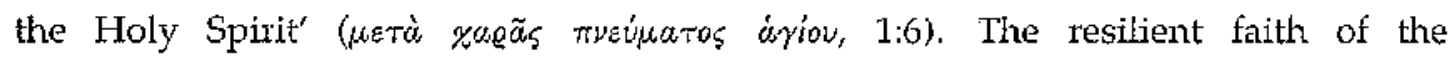
Thessalonians - behind which lies the I Ioly Spirit's activity - is a recurrent theme in 1 Thessalonians. It was because the Thessalonian Chrislians received the word with the

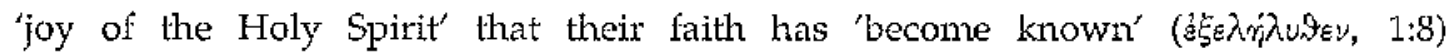
throughout Macedonia, Achaia and beyond (1:7-8). Little wonder then that the Thessalonian conve1ts are Paul's 'glory and joy' (2:20). Indeed, so vibrant is the Thessalonians' faith that it even enables l'aul to 'live' (3:8), a flourish which reveals how faith is something built up (cf. 5:11) corporately. All the more vital then, that what God has given (4:8), and is the causc of their joyful failh amidst perseculion, the Holy Spirit, should not be quenched (5:19).

It is most likely that this same Holy Spirit was thought to be behind what Paul says in

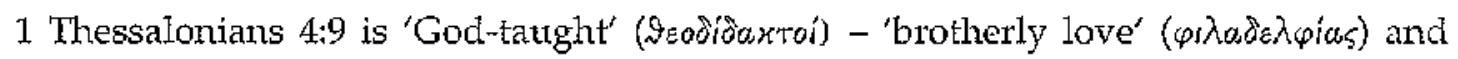

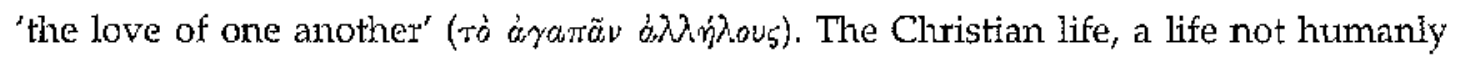
devised but 'God-taught', 146 is to love and serve others - a dedication made known by

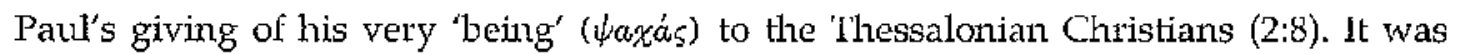
only because of the love Pattl had for the Thessalonians that Patl offers to them not

\footnotetext{
144 The Hebrew roots of $3 x \kappa \lambda$ nqio (referring to a conmunity gathered together at God's calling) are picked up by commentators, on the assumption that Patt is consciously building upon them. See Tarazi, 1982, 22-6 inter alios.

145 Comm. I Thess. I:6.

${ }^{146}$ Interestingly the word, 9so8ijaxto5, is a Pauline neologism. See Malherbe, 2000, 244-5; Richard, 1995, 215-7.
} 
onty, 'what he has, the gospel, but what he is, himself.'147 Paul's self-surrender to the Thessalonian Christians is its own imitation of the One who 'did nol please himself' (Rom 15:3), an early indication of the one who would later boast of becoming 'a slave to al]' (1 Cor 9:19).

A life of sacrificial love, giving to the point of one's very being, is a life of ultimate freedom, a life which in its moments and acts of love witnesses to that which is eternal and radically valid. Paul's life witnesses to that which connot die, ${ }^{143}$ a service which as Thomas implies by his use of John 10:11 has its origins in Christ's triumphant love, "The good shepherd lays down his life for the sheep.'143 This Godtaught $\dot{a} \gamma^{\prime} \pi_{r}$ is, as Maximus the Confessor says in his writing on divinizing love, the first and most excellent good, since through it God and man are drawn together in a single embrace', ${ }^{150}$ The love, which Paul hopes the Lord will help them increase and

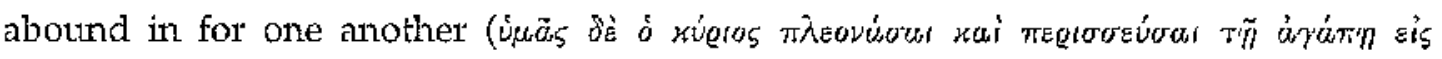
$\dot{a} \lambda \lambda \hat{n} \lambda$ ov, 3:12), is for Maximus the means by which the world and its inhabitants are transfigured, and brought together as one, at the initiative of the One who 'for our sake and from us and through us..,became wholly man'.151 The love of the One who died 'for us', mirrored in the transfigured community which, taught by God, abounds in the same self-giving love, is the means by which God and his people are drawn ever closer in union.

In a world of mouming and 'darkness' (5:4), the sign of what we are to enjoy in the richness of divine life is therefore traced by who we are becoming now through the aid of the Spirit. Expanding in love for one another, 'more and more' (maqureviety $\mu \tilde{a} \lambda \lambda o \nu, 4: 10$ ), the principle of God's transforming grace can be seen to be at work in the life of the church: God is 'calling' us (5:24) and we 'are sons of light and of the day' (5:5).

\footnotetext{
${ }^{147}$ Best, 1972, 102.

148 ef. Rallner, 'The Life of the Dend', 348-9.

149 Lectio IH.I.34.

${ }^{150}$ Maximus the Confessor, 'Letter 2: On Love', translated in Louth, 1996, 85-93 (90). See also Thunberg, 1985, 101-8 un Maximus' vision of deifying love.

${ }^{151}$ Maximus the Confessor, 'Letter 2: On Love', tratuslated in Louth, 1996, 85-93 (87-8).
} 


\subsection{Light and prayer in 1 Thessalonians}

As Thomas recognised, 'light' is an exceedingly rich intra-textual Scriptural term. ${ }^{152}$ P'aul's description of the 'Ihessalonians as 'sons (or children) of light' (5:5), mentioned in an eschatological context, affords us the opportunity to turn to the interpretations 'light' enjoys in the mystical theology of Fastern Christianity. As wc shall see, in Orthodox and Eastern Patristic interpretations of Jesus' transfiguration 'light' possesses both an eschatological depth and an allusion to mystical progression.253

There is a close connection between the light of the transfiguration by which Chrisl's divinily was revealed, the light of which we are children now, and the parousia. ${ }^{154}$ For as at the transfiguration when the disciples see Jesus as who he really is - as the One who is the very life and light of God himself - so the parousia, for tus, marks the full disclosture, the definitive revelation of the life we are carrying within ourselves in this present age. The parousia, and the final judgement which Paul associates with it (3:13), is the definitive unveiling of who, in life, we are and were: the life 'in Christ' which lives by his light, awaiting the day when 'the just will shine like the sun.' (Matt 13:43) As the transfiguration revealed the 'ultimate reality' of Jesus' life, ${ }^{155}$ so it is necessary to say that there is an end to the world which reveals, discloses, unveils

\footnotetext{
${ }^{152}$ Lectio V.I.IIS,

${ }^{153}$ J.ossky, 1976, 217-35. Another connection with this assured spiritual progression could yet be made to Philippians 3:13-14, 'forgetting what lies behind and straining forward to what lies ahead, I press on towards the goal for the prize of the heavenly call of God in Christ Jesus.' This verse, with its notion of epectasis became enormously influential in the mystical writings of Gregory of Nyssa. Spiritual expansion is a constant growth towards maturity, the assured overflowing of the gifts we already have in our possession. As 'sons of light' we are caught up within an economy for which God has created us, and within which our ever-increasing participation in the 'light' is assured. Cf. Gregory of Nyssa, The Life of Moses, \$ 225-6, 'the soul rises ever higher atod will always make its flight yet higher - by its desire of the heavenly things straining ahead for what is still to come, is the Apostle says. Made to desire and not to abandon the transcendent height by the things already altained, it makes its way upward without ceasing, ever through its prior accomplishments renewing its intensity for the flight.' For more on Gregory's doctrine of epectasis see Danielou, 1962, 56-71.

Our spiritual interpretation of Paul's metaphor - 'sons of light' - differ's from those Biblical scholars who interpret the familial imagery as Paul's attempts to console those recently converted in traumatic circumstances. See Malherbe, 1995, 125, "he [Paul] achieves his pastoral pupose by writing a familial, parenetic letter to God's new fanily in Thessalonica'.

${ }_{154}$ Palamas, Triads, II.iii.20. See Mantzaridis, 1987, 220. Our use of the Transfiguration and its interpretation is radical in two ways. First of all, in attempting to understand more sharply what Paul refers to only obliquely, we are turning to extra-Pauline canonical writings. Echoes of what Paul writes about are discerned in non-Pauline texts, a resonance possible to deteet only with the assistanee of the Patristic heritage. (See Louth, 2002, 234443; McGuckin, Y.A., 1989; 1986; Chamberas, 1970). Second, in this use of the Trunstignation we ane answering a complaint of Karl Rahner that there is a contemporary lacuna in theological readings of the events of Yesus' human life. (See Ralner, 'Current Problems in Christology', [90-2). Here, once again, our Christ-ruled reading of Paul comes to our aid.

${ }^{155}$ Palamas, 'Homily 34', \& 7, 'Christ was transfigured, not in the sense of assuming that which he did not have, not that he was changed into something which he was not; but rather', that which he revealed to his own disciples was that which he was', translated in Rogich, 1988, 164.
} 
our 'ullimate reality', 156 the 'light' by which we live. So too, as the disciples on the mountain were bathed in the divine light of Jesus' 'inborn glory of the Godhead', 157 when we attain the state of being 'with Jestus forever' (4:17) we shall be intundated witl the vision of the divine glory, ${ }^{15 s}$

'in the age to come we shall always be with the Lord, beholding Christ refulgent in the light of the Godhead.'159

The 'day' to which we belong as 'sons of light' (5:5), this definitive manifestation of our complete transfiguration by grace, is the end of what is now a hidden, secret, invisible glory', and a disclosure of that which is 'unfailingly glorious', 160

'For what is our hope and joy and crown of glory - is it not you -
before our Lord Jesus at his coming? For you yourselves are our
glory and joy!' (2:19-20).

The light of the Spirit we are now (5:5), in our 'bodies' as Paul says in 2 Corinthians $4: 6$, is therefore a pledge of the eschatological light that will dazzle and transform us, in a manner similar to the dazzling light which revealed the true nature of Jesus' body on Mt Tabor: ${ }^{161}$ United to God in Christ's saving work, we already carry within

\footnotetext{
156 The phrase is from Williams, R., 1982, 83.

157 John Damascene, 'Homity on the Transfiguration of our I ord Jesus Christ', \& 10. See I,outh, 2002, 234-43.

${ }_{158}$ Palamas, Triads, Iru.i. 10 citing Pseudo-Dionysius.

159 John Damascene, 'Homily on the Transtiguration', $\$ 15$ (emplasis added).

${ }_{160}$ Barth, 2002, 78. See also Gillette, 1997, 90.

${ }^{161}$ The leaps we are making here are exaclly those Gregory Palamas makes in Trikts, JII.iii.9, 'Similarly, the chosen disciples saw the essential and eternal beauty of God on Tabor...the very formless form of the divine loveliness, which deifies man and Inakes him worthy of personal converse with God; the very Kingdom of God, eternal and endless, the very light beyond intellection and unapproachable, the heavenly and infinitc light, out of time and eternal, the light that makes immortality shine forth, the light which deifies those who contemplate it. They indeed saw the same grace of the Spirit which would later dwell in them...they contemplated that uncreated light which, even in the ages to comc, will be ceaselessly visible only to the saints'.

Earlier, Pseudo-Dionysius had linked the gospel account of the transfiguration with 1 Thess $4: 17$. See 'The Divine Names' in Psetdo-Dionysitus: The Conplete Works, 47-131, 'But in time to come, when we are incorruptible and inmortal, when we have come at last to the blessed inheritance of being like Christ, then, as scripture says, "we shall always be with the I.ord." In most holy contemplation we sliall be ever filled with the light of God shining gloriously around us as once it shone for the disciples at the divine transfiguration,' (52).

Origen, in commenting on Matthew's transfiguration account explicitly links the Transfiguration with 1 Thess 5:5: 'Commentary on Matthew', XII.xxxvii.
} 
ourselves that light which, banishing all shadows and images, will reveal fully who we are becoming through the Spirit-led life. We have now, as 'sons of light' (5:5), a principle of the future's shape. For just as Christ is the true light and reveals himself as such to the three disciples on Mt Tabor, so at his coming in dazzling brightness, God will reveal just how much he wills our bodily transformation, something he had already signalled at the transfiguration,

'Hle will come again with His body, as I have learned, in such form $\mathrm{He}$ was seen by His disciples on the mountain, as He showed Himself for that moment when His deity overpowered His carnality.' 162

Precision is important here about the kind of parailels drawn. Whether the light we have now as children awaiting full maturity is the radiance of Christ's glory reflected in our being, or whether it is the energy of Christ moving within us is of less importance than stating categorically that Christ's glory and that glory in which we both share in and anticipate are not to be ontologically confused. Pulling close to the light revealed in Christ we become participants in the light and 'of' it, united with its forward expansion, but not in any way confused with its uncreated essence,

'I-Ie who participates in the divine energy, himself becomes, to some extent, light; he is united to the lighl; and by that light he sees in full awareness all that remains hidden to those who have not this grace...for the pure in heart see God..who, being light, dwells in them and reveals Himself to those who love Him'.163

See also ST 3 a (1.45 a.2 ad.3, 'Just as the splendour of Christ's body [on Mt Tabor] represented the future splendour of his body, so the splendour of his clothes signified the future splendour of the saints.'

162 Gregory Nazianzen, 'St Gregory Nazianzen's Letter to Cledonius', translated in McGuckin, I.A., 1994, 390-9 (393). In much Patristic thought the T'ransfiguration, and the transformative light associated with it, was interpreted as a sign pointing towards the transformation of the parousia. After the Patristic period Gregory Palamas (1296-1359) became most associated with this thinking. Swe Rogich, 1988, 145-7; McGuckin, J.A., 1986, 120-5; Mantzatidis, 1984, 96-104; Meyendorf, 1964, 193-5. This eschatological understanding of the transfiguration may actually be sympathetic to the redactional interests of Luke's account of the episode. See Trites, 1987, 77, 80.

16.2 Gregory of Pulamas, 'Hamily on the Presentation of the Holy Virgin $\mathrm{i}_{11}$ the Temple'. Cited in and translated by Lossky, 1976, 224. We are making reference here to Palamas' insistence of the distinction between God in Christ's 'essence' and 'energies'. Palamas' notion of our unity with God, rnate possible by God in Christ incarnate, was never confused with this unique and unrepeatable hypostatic union. God's energies provide the basis tor our mystical experience, but we do not in any 
This life lived out in the light, straining towards the uncreated and transformative light of the parousia is distinguished by ils conslancy of prayer. In the history of the church, and especially those with strong monastic traditions, Paul's injunction to

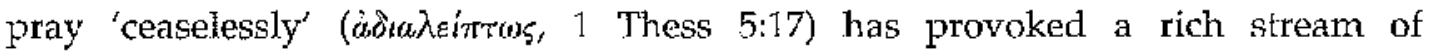
thought. ${ }^{164}$ Although some have read Paul's injunction in the strictest literal sense, in the sense of 'saying prayers', 165 as early as Origen the Fathers recognised that the only way to read Paul's injunction was by uniting.

\begin{abstract}
'prayer with the deeds required and right deeds with prayer. For' the only way we can accept the command to "pray constantly" as referring to a real possibility is by saying that the entire life of the saint taken as a whole is a single great prayer. What is customarily called prayer is, then, a part of this prayer.'160
\end{abstract}

In its mystical sense prayer is the ascent of the individual to God, the rising up of the whole person into the presence of God. ${ }^{167}$ Prayer is the spiritual approach to God, of which our glorification at the parousia is the final stage. Set in such a key, prayer is not purely a vocal exercise as some have erroneously thought, but an active and ceaseless parlicipation within God's vision and work. As Kallistos Ware articulates,

way approach the essence of God. Palamas was keen on giving the example of a sun and its rays as a parallel for the essence and energies distinction. See Triads, MI.ii.13, 'I believe no one would deny that these rays are its energies or energy, and that one may participate in them, even though the essence remains beyond participation.' See also Triads, III.ii.14; III,iii.11. Sec 'The Theology of Light in the Thought of St Gregory Palamas' in Lossky, 1974, 45-69, 'God reveals Himself, totally gives Himself in His energies, and remains totally unknowable and incommunicable in His essence.' (55). For the essencelenergies distinction prefigured in Patristic thought and articulated fully by Gregory Palamas in his dispute with Banrlam see MoGuckin, J.A., 2001, 123-30; Williams, A.N., 1999, 102-27; Russo, 1988, 172-9; Lossky, 1976, 67-90. For a critique of the distinctions Palamas draws see Williams, R., $1977 \mathrm{~b}$.

${ }^{164}$ For overviews of the history of the interpretation of this verse in Eastern Christianity sce "Pray Without Ceasing: The Ideal of Continual Prayer in Eastern Monasticism' in Ware, 2000, 75-87; Mantzaridis, 1984, 90-95; Meyendorff, 1964, I41; Hausherr, 1978, 119-89, For the interpretation of this verse in Wostern Medicval Christitunity see Tugwell, 1988b, 271-9.

${ }^{165}$ The fourth and tifth century monaslic movement of Syria and the Neat Fast - the Messalians interpreted Paul's injunction quite literally, and prayed vocally to the exclusion of everything else. See 'Pray' Without Ceasing' in Ware, 2000b, 75-87 (76-7); Mantzaridis, 1984, 91; Hausherr, 1978, 126-9. Conmenting on 1 Thess 1:2, Tarazi, 1982, 30-3, Jays much emphasis on Paul's constancy of yocal prayer and thanksgiving.

160 Origen, 'On Priyer', XII.2.

${ }^{167}$ Thus Gregory of Palamas (1296-1359) writes in Triads, II.i.30 on 1 Thess 5:17, 'We supplicate with this continual supplication not to convince God, for he acts always spontaneously, nor to diaw him to us, for he is everywhere, but to lift ourselves up towards him.' Cited in Meyendorff, 1964, 141. For Stănilone, 1982, 10, pure prayer is 'an awareness of being totally absorbed in the reality of Gocl.' 
praying 'ceaselessly' is 'not so much an activity as a state. ${ }^{\prime} 168$ The mainstream of eastern monasticism has therefore understood Paul's injunction as a call to take on an implicit state of prayer, a call 'lo be prayer' in everything we do, driven by a continuous wonder at God. This assumption of prayer within the total being of the loving individual before God is, as Kallistos Ware points out, a road of discipline and faith in God's grace.169 Being in a state of continual prayer ... 'being prayer' - is not something that comes automatically or cheaply. Integrating the state of prayer, as communion within God and ascent to God, within our whole selves (body, soul and spirit) and within all that we do is ultimately a question of faithful discipleship, a responsibility open to all Christians and not just a spiritual élite,

'Sacred Scriphure never commands us to do what is impossible. The Apostle himself recited Psalms, read Scripture, and served others, yet he prayed without ceasing. Continual prayer means kecping the soul attentive to God with great reverence and love, constantly hoping in him. It means entrusting ourselves to him in everything that happens, whether in things we do or in events that occur.' ${ }^{170}$

The state of constant prayer becomes, in this perspective, a drive towards union with God, ${ }^{17}$ a future in which we are promised being 'with Jesus forever' (4:17). The emphasis of constant prayer is not so much on vocal words directed to God (although that clearly has an important role) but a ceaseless enjoyment of the life of God within one's own life. Moreover, we would want to add the proviso that 'being prayer' is not something grasped in full now, but must await the final consummation of the parousia. Just as we have within us the light of God now, but at the end will shine with light in all our being, so too at the end will we be what we practise now -ceaseless prayer.

\footnotetext{
108 'Pray Without Ceasing' in Ware, 2000, 75-87 (81).

169 'Pray Without Ceasing' in Ware, 2000, 75-87 (84).

${ }^{170}$ Maximus the Confessor, Liber Asceticus, no. 25. PG 90:929D; 932A. Cited and translated in Hausherr, 1978, 137.

${ }^{171}$ Palamas, Friads, II.iii.35. See Lossky, 1976, 206-12.
} 


\subsection{The 'dead in Christ'}

l'aul's desire is that the Thessalonian Christians should see no separation between the biologically dead and alive, because in dying 'for us' Christ enables both the dead and the living to live with him (5:10).172 In this context Paul's assertion that the believer's relationship with Christ survives death is not surprising. If God 'raised Jesus from the dead' (1:10) it seems apt that Paul declares to the church that is also 'in God the Father' (1:1) - i.e. the same God who raised Jesus - that their dead are 'in Christ' (4:16).

This image of 'the dead in Christ', will occupy our attention in this section. This is much more than a synonym for 'deat Christians'. Paul, it is true, uses the phrase 'in Christ' in a number of ways, not all of them conveying a sense of mystical participation, 173 bul in this instance there can be little dispute that it means much more than what we understand by the term 'Christian'. ${ }^{174}$ There is much more depth within this phrase than 'dead Christian' would allow.

Close reading suggests that il is significant that the text does not refer to the dead who were in Christ', but instead refers to a present reality running across the temporal interruption of death. The text clearly refers to the dead who are in Christ, an interpretative move supported by 5:9-10, where both the dead and living are caught up within the saving dominion of 'the Lord Jests Christ'. Death presents no barrier to the Lordship of the One who 'died and rose', for in himself he has broken through death's boundary, and has the capacity now to embrace both the dead and living. Thesc three words - vexeoi s' Xetor although dead we continue to be saved by the force that is our salvation, for we remain alive to the outworking of God's saving resurrection.

\footnotetext{
${ }^{172}$ Sanders, $1977,465$.

${ }^{1 / 3}$ Apart from the mystical-locative sense 'in Christ' enjoys in 1 Thess $4: 16$, Paul cetn deploy 'in Christ' in an instrumental sense, with the meaning that Christ is the instrument of God's salvitic will. One example is Rom 3:24, 'the redemption that is in Christ Jesus'. Seifrid, 1993, 436, claims that Paul uses this instrumental sense 151 times.

${ }^{174}$ As Bultmann, 1965, 328-9 would suggest, arguing against Schweitzer's mystical interpretation of the phrase. There are perhaps two reasons why we can say that 'in Christ' means much more than 'Christian'. First, it is surely significant that the phrase is al ways linked to claims of Jesus' Messiahship or Lordship. Thus although we find Pulul using 'in Christ', 'in Christ Jesus' or 'in the Lord' never in the

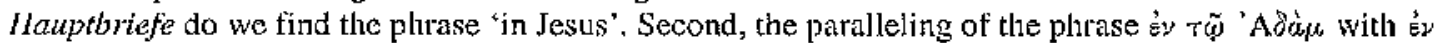
$\tau \bar{\mu}$ Xer $\sigma \tau \vec{\varphi}$ in 1 Cor 15:22 would suggest a juxtaposing of two different spheres of power and dominion. The 'in Christ' formula has been vigorously debated in Pauline studies: see Scifrid, 1993; Wright, 1991, 41-55; Wedderburn, 1985; Moule, 1977, 54-69; Best, 1955, 1-33.
} 
To talk of 'the dead in Christ' is to be involved in the most risky kind of talk. On the one hand, to talk of the 'the dead in Christ' is clearly metaphorical in some way, in the sense that our language cannot entitely correspond to the transcendent reality it is trying to depict. Since our union with Christ is an operation of God, through the activity of the Holy Spirit, ${ }^{175}$ we should be looking for recognition that there is no neat elision between our language and full perception. Although there is no tidy correspondence between our language and the reality which it is trying to evoke we can say that 'the dead in Christ' is pointing to something that is really true. The dead really are in Christ, though we should not confuse that reality with the language under which we labour. ${ }^{176}$ Here we meet the paradox of eschatological faith - the dead really are in Christ, though this is not a reality which our language can capture or contain. In this sense the language of Scriptural revelation is the revelation of eschatological mystery, not clarity. ${ }^{177}$ Within the very language itself is hidden a reality which, although we may unfold and unravel, we cannot expect to fully possess in understanding.

The use of 'in Christ' is a shorthand and pointer to the mystical reality of where the dead are now: those who have died believing in the saving work of Christ Jesus are still within the fold of his grace, and will rise from the dead to meet with all who have died after them. This is akin to passages where Paul talks of Christ living in him (Ga1 $2: 20$ ), language which although it points to something that is ultimately true, it is not verifiable in any crude physical sense. Clearly there would be no physical tests we could apply to affirm whether or not Christ is 'in' somebody, or we are 'irn' Christ, but that does not in any sense make them untrue statements of reality. The reality such language is pointing to is therefore the participation of oturselyes and our futures within the saving works of God in Christ. Living in Christ, and Christ living within us, we no longer lead a created life, but rather the etemal life of God who indwelt

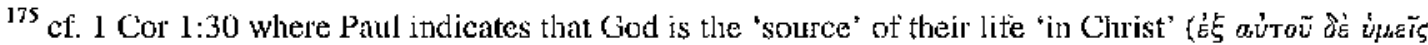
É Hooker, 1978, 475-6.

${ }^{176}$ Our views here are equivalent, in some way, to those of Sanders, 1977; Robinson, 1957; Schweitzer, 1931, 127, who arguc that Paul's use of the 'in Christ' formula is pointing to something that Pau? thought of as a real state. We are agnostic about whether or not Pal intended his 'in Christ' to convey this realism, having much more conviction that it can legitimately be theologically exegeted in this way, as words pointing towards a salvific reality.

in' cf. Rahner, 'The Hermeneutics', 330.
} 
within Jesus. ${ }^{178}$ What is happening to those in Christ is the communication to us of the life Christ possessed and enjoyed by virtue of his divine union. ${ }^{179}$ The pattern of God in Christ's suffering life, deatl and triumphant resturrection is now open to all, 'in Christ', 'I have been crucified with Christ; and it is no longer I who live, but it is Christ who lives in me.' (Gal 2:19-20).

Christ's grace (which we explored in the 'for us' formula) and our faith meeting, Christ passes his dominion over death to all those 'in' him. United to Christ's death 'for us', being 'in Christ' is faith's appropriation of all that Christ has achieved 'for this',

\begin{abstract}
'as long as Christ remains outside of us, and we are separated from him, all that he has suffered and done for the salvation of the human race remains useless and of no value for us.....all that he possesses is nothing to us until we grow into one body with him.' ${ }^{\prime} 80$
\end{abstract}

Eastern Christianity's understanding of the synergy between God's grace and our faith might help here in exploring the relationship between Christ, and those united to him, in life or death. ${ }^{181}$ 'Dead in Christ', the benefits of his divine power are transferred to our humanity, yet with no suggestion that the one becomes the other. The classical hypostatic images, which communicate union without confusion are clearly relevant to understanding our union 'in Christ'. 'Dead in Christ' our union with the risen Christ is like the relationship between a flame and a wick, ${ }^{182}$ or between

\footnotetext{
${ }^{178}$ Palamas, Triads, III.i.35. So Meyendorff, 1964, 182, on Palamas' soteriology links our salvation 'in Christ' indissolubly with the hypostatic union, 'The 'hypostatic union' of divinity and humanify in Jesus Christ is the very foundation of salvation, and therefore of deification: in Christ, humanity has already participated in the uncreated life of God, because the flesh has truly become the "flesh of God'.' It is important to clarify, however, that Eastern Christianity has always been aware that there is only one, unrepeatable hypostasis: Williams, A.N., 1999, 124-5. Whilst the incarnation has set up the renewed possibility of a reciprocity between Gad and humanity there is never any suggestion in Eastern Christian thought of a mingling of the essence of divine and human natures. See n. 163.

${ }^{170}$ See Keating, 2003, for this motif in Cyril of Alexandria's exposition of deification.

${ }^{180}$ inst. IIl.i. I.

181 Williams, A.N., 1999, 133, 'the East conceives of syncrgy not so much as the cooperation of God and humanity considered as equals but as the process whereby human persons offer their wills to God's sanctifying action.' See the discussion of 'theandric synergy' in Maximus' theology in 'Thunberg, 1985, 53-4.

${ }^{182}$ Gregory of Nyssa, 'An $\Lambda d d r e s s$ on Religious Instiuction', § 10.
} 
the heat and sharpness of a searing sword. ${ }^{183}$ Just as there is in these instances two distinct operations, yet one effect, so too 'in Christ' are the effects of Christ's union with the Word communicated to us without confusion. Whilst never becoming ontologically confused with Christ, his effects are fully communicated to us.

To dic 'in Christ' is therefore to enter into a movement and dynamic of grace initiated by God in Christ. In a Rahnerian sense it is to make a supreme decision of freedom, allowing ourselves to be defined by the mysterious boundlessness of Christ and his future, taking the choice in freedom to allow our lives to reach their point of consummation in Christ's grace. ${ }^{184}$ Dying in Christ, we enter the realm of 'the dead in Christ', becoming in death what we chose to be and align ourselves with during our life. Our lives and our deaths, in Christ, are thus radically interwoven, just as Christ's death was lilled with the life of God. To be dead in Christ is to be caught up within the saving work of Christ, open to his grace and assured of a conformity to the pattern of Jesus' life, death and resurrection. God in Christ dying for us becomes himself the boundary of the death that bounds us, and so we dying in Christ bring all that our deaths signify and represent into a point of connection with this life-saving force, Dying 'in Christ' as an act of faith is a statement that God remains as God the Healer and Redeemer in the very face of death, that God in Christ has now invaded and defeated the threat of death.

\subsection{The 'sleeping' Christians}

Commentators are keen on noting Panl's metaphor for the dead in 4:13, they are 'sleeping' (rorkwuávos) not dead. ${ }^{185}$ For some, Paul is here deploying a euphemism for

\footnotetext{
${ }^{183}$ John Damascene, 'Exposition of the Orthodox Faith', IIY,xy. The image of a burning-hot sword, which acquires both the property of a searing heat and a cutting edge in union, without there being any change in either property was a favourite Patristic motif. See Maximus the Confessor, 'Difficulty 5 ', translated in Louth, 1996, 171-9 (178). Louth, 1996, 216 n.22, notes further Patristic deployments of this image.

${ }_{184}$ Rahner, 'On Christian Dying', 287; 'Christian Humanism', 199; 'Christian Dying', 252-3. cf. McDermot, 1980, 54.

185 Best, 1972, 185, rigorously maintains that in Paul's usage the term has no reference to an 'intermediate state'. What we build here upon Paul's use of the word 'sleeping' might appear to have no justification in the sense that Paul intended. Nevertheless, as throughout our thesis, our role is less that of a 'curator' and mure that of exploring the text's polysemy and meaning through time. Moreover, as we indicated in our discussion of Best's commentary in chapter 1 (\$ 3.2$)$, whilst it is certainly not unhelpful to know the prior history for concepts and terms which became part of the early Christian discourse, these scholarly hypolheses of historians cannot form the only foundation for the essentially expansive task of doctrinal discemorrent.
} 
death, akin to the contemporary idiom of 'passing on'. ${ }^{186}$ Charles Wanamaker notes that the idiom, in its Grock and Hcbrew deployment, conveyed no presuppositions of an afterlife. ${ }^{167}$ Rather than relying on the word's pre-history jn Hebrew usage, there may be potential in concentrating upon its literary context. Fruitfully, Martin Luther observes that in 4:14, Paul does not use the same verb to refer to Christ's own death

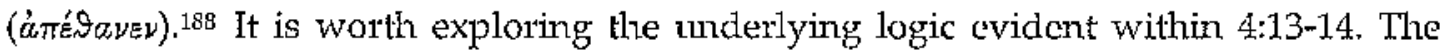
Thessalonian Christians are not to grieve 'for' (yà) those who believe that Christ 'died and rose' must see that the 'dead in Christ' (4:16) are in actral fast sleeping

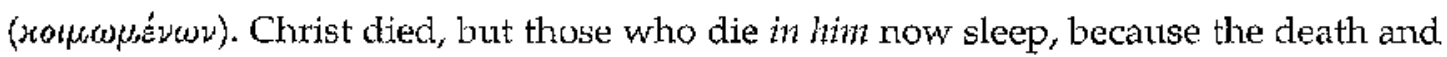
resurrection of Christ, 'in this way' (oüTws), points to our conformity within this act of rising to new life. ${ }^{180}$

I.ike 'the others' (oi homoi, 4:13) our death is therefore a tangible end to something physical. But there is hope for those who die 'in Christ' becalse Christian death has close parallels with sleep. ${ }^{190}$ On the one hand there is in both sleep and death a dumbing of the senses, ${ }^{191}$ but also in both 'sleep' and with 'dying in Christ there is the expectation that we will wake again 'refreshed and restored'. ${ }^{192}$ Just as Christ rises out of the darkness of hell and into the dawn of a new day, so his rising at the first light points forward to the glory awaiting our bodies' redemption at the 'Day of the Lord'.193 Christ's own resurrection at daybreak was, in every way, a proleptic pledge of the redemption awaiting our bodies as we awake from oux sleep,

'Christ rose at daybreak, that is when light first began to appear. This signified that he was to lead us to the light of glory through his resurrection. So too he died at nightfall, the beginning of

\footnotetext{
186 e.g. Richatd, $1995,226$.

187 Wanamaker, 1990, 167.

188 Luther, 'Two Funeral Sermons', 233, 'The [Paul] rather spuks more sternly of Christ's death than ours and says: Since we believe that Christ died. But of us he says that we do not die, but only fall asleep. He calls our death not a death, but a sleep, and Christ's death he calls a real death.'

189 One would not want to stretch this ton far, for it is cleas that in the sense that Jesus was resurrected, his death too had slumber-like qualities. What Luther points to, correctly we think, is the transformation open to all believers: that in dying and rising, Christ tansforms our death into something from which we will awake.

${ }^{190}$ CD IIL $2,638-9$.

191 So Luther, 'Two Funeral Sermons', 239.

192 Lectio IV.11.93; Duffy, 1969, 35.

${ }^{193}$ cf. $S T$ 3a $q .53$ a. 2 ad. 3.
} 
darkness, to show how through his death he had destroyed the darkness of our fault and penalty.' 194

At the very least we can concur with Barth when he notes how strikingly poaceful the image of believers 'falling asleep' is, a peace which is itself an image of the reconciliation delivered by God in Christ going ahead and dying 'for $u^{\prime}$ '. If we can assume that Paul was picking up and adopting an early Christian term for Christian death (which would appear to be corroborated by the use of the aorist passive, Exkoupism, in Acts 7:60) the word denotes a notable pacificity, a conviction that death itself is now 'strrounded by the peace of God.'195 Death, having passed through the life of God in Christ, has been denuded of its grip over us, and our state of dormition symbolises our patient anticipation of death's final defeat,

'It is true, we still die as before, but we do not remain in death; and this is not to die. The power and the very reality of death are just this, that a dead man has no possibility of returning to life. Bul if after death he is to be quickened and, moreover, to be given a better life, then this is no longer death, but a falling asleep. ${ }^{\prime 126}$

\subsection{The consummation of the world in God's grace}

Towards the end of 1 Thessalonians 4:13-18 Paul turns to a number of fantastic images in his portrayal of the victory and consummation of God's grace over death: there will be a shott of command, God's trumpet will sound, ${ }^{197}$ archangels will cry out, Christ will descend from heaven (where he reigns), the dead and the living will be 'catight up', and both will rise to a meeting with Jesus in the clouds $(4: 16-17)$.

\footnotetext{
${ }^{194} \mathrm{ST} 3 \mathrm{a}$ q. .53 a.2 ad. 3 .

${ }^{195} \mathrm{CD} \mathrm{LL} / 2,639$.

190 John Chrysostom, In. Haebr., Hom. 17:2; PG 63:129. Ciled in and translated by Meyendorff, 1983, 162.

${ }^{197}$ As Thomas' commentary (Lectio IV.II.99) witnesses, Christian tradition commonly understrood Paul's reference to the 'shout of command' with reference to Jn 5:28. Cyril of Alexandria tnderstands this resurrection call in line with Jesus' command to Lazarus to conne out of the cave (Jn 11:43), and Piul's reference to the 'trumpet of God' in line with the Feast of the Tabernacles, 'Celebrate it as 'a memorial of trumpets' (Lev 23:24). For when human bodies are about to be set up again, as tabernacles, and every man's soul is about to take to itself its own bodily habitation in a way as yet unknown, the masterful command will be previously proclaimed, and the signal of the resurrection will sound forth, even the 'the trump of God' (1 'I'hess 4:16), as it is said. As a type therefore of this, in the case of Lazarus Christ uttered a greal and audible cry' (Conmentary on the Gospel According to St John, VII (on Jn 11:43-4)).
} 
Properly used these symbols and images of the victory of Christ's communion over death should be constantly exerting us to know more of God's transcendent will through them. Awareness that these images do not in themselves depict reality, 198 and yet a reality is depicted through them is intrinsic to a knowledge of God's mystery attuned to apophaticism. In vocabulary familiar to practictionexs of apophaticism our reading must be disciplined by the 'dazzling darkness' of these bright, yet necessarily opaque images. 199

Reading this beguiling mixture of imagery 'around Christ' it becomes clear that the key image is the representation of us ascending, and Christ descending (once again) to meet us. Reference should be made here to our climactic understanding of Jesus ${ }^{r}$ death 'for us' (\$ 3.3), most fully understood as a 'wondrous exchange'. Just as God in Christ initiated the salvific process of restoration by 'coming down' or 'descending' to our level, so we are assured that our future is of 'rising up' and fully enjoying in our bodily selves the life of God.200 The images which the text employs - the Lord will

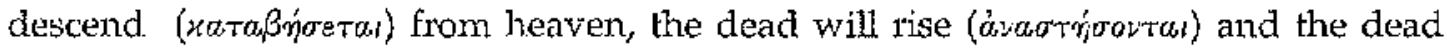
and living being caught up together to meet Jesus in the clouds - point towards the whole reality and triumph of the incarnational drama: God in Christ descending to our level, to raise us the his level.201 The trimmphant conchusion of this process of salvation, finally manifest at Jesus' parousia, is its own microcosm of the cosmic reconciling exchange: he descends to meet us and we rise up to his level. Jesus coming down from heaven symbolises that which is true of his incarnation: that he is both the One who comes down from his Godhead, and he is eternally the One who lifts us up, ott of our present existence and into the potential of life with God forever (4:17). Only at the parousia is this divine plan complete, for only then do we body and soul and spirit' live with Jesus eternally,

\footnotetext{
${ }^{198}$ cf. Yarbro-Collins, 1994.

199 ef. Stăniloae, 1994, 105-7; Ware, 1975.

${ }^{200}$ So Cytil of Alexandria, On the Unity of Christ, 64, 'Yet we became heavenly beings, receiving this gift in Christ. He is from God, from on high, and naturally God, yet he came down to our condition in a strange and most unusual manner...so that we too might abide in holiness and incorruplibility like him.'

${ }^{201}$ A comtion strand in Byzantinc and Orthodox thought, e.g. Maximus the Confessor, 'Ad Thalassium 22', translated in On the Cosmic Mystery of Jesus. Clurist, 115-8. See the discussion of Maximus the Confessor in Blowers, 1993, 228, and I.ossky, 1976, 136. For an Anglican assertion of this theme see Allchin, 1988, 68-9.
} 
'the Lord, putting on the body, became man, so we men are deified by the Word as being taken to Him through His flesh'.202

There is always the risk of saying too much about eschatology and our end 'in Christ'. It is important to outline what we can and cannot say the resurrection of the whole of our dead selves represents in the saving will of God in Christ. The resurrection of our bodies is the triumphant conclusion to the reconciling exchange revealed by God in Christ. Our bodies are something desired by God, for from creation, via the whole drama of incarnation, and through to our bodily resurrection, bodies are revealed as something which God both uses and in which he takes delight. ${ }^{203}$ The parousia is the triumphant conclusion of our grace-filled retuin to God, the necessary final chapter of the resurrection by which God desires to live with us in harmony and for eternity $(4: 17)$.

While it is not for us to predict the 'how' of the transformation of our selves before God, it is the legitimate role of theology to explore how the parousia acts as an attestation of the God whose purpose for humanity will reach consummation. Just as God in Christ offers all the promise of his life-giving power, so we in Christ take on and adopt and become all that God himself is in Christ.204 To be 'in Christ' is therefore to have made an eschatological decision, 205 that our fulures are somehow more than just with God but, mystically, located within God. What will be revealed with the consummation of God's grace is what we have begtn to know 'in Christ', his story becoming our story. Like Christ we will butn and arise with the eternal life-giving force of God himself, living with Jesus 'forever' (4:17) we will be clothed in the blessings of eternal life which God has always enjoyed. Just as God is eternal - living in a mysterious commingling of past, present and future - so we will be eternal, and

\footnotetext{
202 Athanasius, 'Four Discourses Against the Arians', III.xxvi.34. Deification, vital to Fastern Patristic soteriology, is most linkel with the interpretation of 2 Peter 1:4 (and Ps 82:6), and less with the Pauline texts. However Breck, 1992, 119, tentatively links Paul's Christ-mysticism in I Thessalonians 4:16 with 'participation in divire life' and hence with theosis. See also Harrison, N.V., 1997, 431; Russell, 1988. For Orthodox theology and the Eastern Fathers deification has always been seen as the mutural extension of the effects of the Incarnation. To the extent that God in flesh participated in the things of humanity, so too humans can now participate in God's life.

${ }^{203}$ Rahner, "The Body in the Order of Salvation', 71-4. See also Williams, R., 1996, 59.

${ }^{204}$ As Hooker, 1978, 476, states plainly, "'To be in Christ is to be identified witl what he is.'

${ }^{205}$ cf. 'Dominion and Kingship: An Eschatulugical Study' in Lossky, 1974, 211-227, 'Fschatology becomes present at the moment when man becomes capable of co-operating in the divine plan.' (224).
} 
living with Jesus in this state the reconciling exchange will have reached its triumphant conclusion.

Talk of eschatology is therefore located within a curious paradox, a constant balancing out of the necessarily hidden quality of the future in its very futurity, and the confidence that in Christ we have a certain revealedness to the nature of our fulure logether:216 While eschatology must, of necessity, remain 'incalculable, uncontrollable and inconceivable', ${ }^{207}$ Christian theology is in the position of insisting that the principle of the world's end - God in Christ - has been and is already radically interwoven into the form of the world. The incarnation, in its essential act of filling humanity with the mystery of divinity and so fusing the two, cuts across any system which insists upon the immanence of eschatology increasing in inverse proportion to eschatology's transcendence. Christian eschatology, the world's end in the God who revealed Christ, camnot be wholly transcendent because Christ has already pulled God's will and his world closer together, in a similiar way that the dead and the alive already share a state of living 'in Christ'. Christian eschatological existence is thus defined by the curious shape, that we are,

'living in time by that which is beyond lime; living by that which is not yct come, but which we already know and possess. ${ }^{208}$

But to retain the paradoxical element to eschatology, just as soon as we think we can discern the principle at work in the world's consummation we must re-commit ourselves to the utter transcendence of the world's future. No room can be afforded for anything that looks like 'evolutionary' eschatology, 209 anything that smacks of our' progress of advance.210 Any linear models of eschatology, behaviour that submits eschatology to predictability, assimiliation or closure needs to be reminded that the end, coming 'like a thief in the night' (5:2), is always a future in God's hands. Such an

\footnotetext{
206 Rahner, "Christianity and the "Now Man", 135, "in Jesus Christ...the future has alroady been decided as to its final sense and content'.

${ }^{207}$ Rahner, 'Immanent and Transcendent Consummation of the World', 278. See also, 'The Question of the Future', 181.

${ }^{208}$ Sehmemann, 1990, 95.

${ }^{200}$ Rahner, 'A Fragmentary Aspect of a Theological Evaluation of the Concept of the Future', 236.

210 As Pnlamas' theology might suggest if Meyendorff, 1964, 193 is accurate in asserting that the reality of our futures is something 'progressively assimilated in the spiritual spluere.'
} 
eschatology will properly place more emphasis on the experience of its transcendence, than on our ability to deduce its movement. ${ }^{211}$

The promise of the second coming is that we will become gloriously and finally what we are in the process of becoming in the life of the Spirit. What we decided in favour of and grew into in the shape of our freedom in time will be ours in the full fruit of eternily.212 Crossing over from our time into God's time as eternity, the future that was always God's is revealed as eternally valid and enduring, where everything we have reached for in life attains its definitive status. ${ }^{213}$ Risen into the life and communion of the triune God, what we were in part and in shadows, we will become in full. Only at this stage will symbols and likenesses rest. For now, though, we have little choice but to continue with our images, until as Gregory of Nyssa assures us,

'that moment when we shall be taught the mystery of the Resurrection by the reality of it...[for] every calculation that tries to artive conjecturally at the future state will be reduced to nothingness by the object of our hopes, when it comes upon us.'214

${ }^{211}$ cf. Webster, 2000, 20.

${ }^{212} \mathrm{cf}$. Rahner, 'Ideas for a Theology of Childhood', 35; 1978, 437; 1985, 102.

213 cf. Rahner, 'Theological Observations on the Concept of 'lime.'

${ }^{214}$ Gregory of Nyssa, 'On the Soul and Resurrection', 464. 


\section{Conclusion}

In concluding this thesis we tundertake three tasks. First, it is worth reminding ourselves of the hermeneutical journey undertaken. Second, we must reflect on the integrity of Part III's conversational mode of interpretalion. Third, we offer some departing images through which and with which our theological exegesis might be best seen.

\section{(1) The hermeneutical joumey travelled}

The thesis began with a critique of hitherto dominant historical-critical readings of 1 Thessalonians. For James Dunn, offering a general defence of historical-criticism, the Biblical text is 'first and foremost' a historical text, ${ }^{1}$ witnessing chiefly to a historically grounded communication. Dunn offers no consideration on how, free from the distracting concern with history and origins, the truth of Scripture resides within the rich field of meaning it sets in motion. Similarly, for Karl Donfried the theology of 1 Thessalonians is only ever a meaning that originally served a situation lying in an event behind the text. In Donfried's reading of 1 Thessalonians anderstanding the text's historical origins is to grasp its theological message. Both Dunn and Donfried reveal the dominance of historicist tendencies within New Testament studies, the assumption that 'in order to understand somcthing, the essential mode is to get at its origins. ${ }^{2}$

Historical-critical readings, we thus went on to argue, are hampered by a restricted notion of meaning and truth; by an assumption that fixes the language of Scripture into a restrictively reflective relationship between text and original context; and by a misteading of Scripttre's quality of 'witness'. All these claims were advanced in relation to specific examples of scholarship on 1 Thessalonians. 'I'he majority of the scholars examined remain fascinated with the historical Paul, with his personal religious and social context, and with the context in which he evangelised and taught. In a very limited sense there is a legitimacy to these projects, insofar as the Bible is clearly at one level a historical document and can be studied just as one

\footnotetext{
${ }^{1}$ Dunn, 1995, 346.

${ }^{2}$ Bart, 1996, 106.
} 
wotld study any other ancient document. Revelation, as Barth reminds us, 'has its time, and only in and along with its time is it revelation.' 3 It is, however, the particular responsibility of theologians to point out that an inappropriate fixation with the authority of origins bypasses what fascinated and transfixed Paul - the transfiguration of the world by virtue of the divine-human encounter that is God in Christ, and so the fact that he was 'totally absorbed by something (Someone!) other than himself.' 4

Historicist scholarship, as we identified it, places excessive emphasis on an always putative atthorial intention, and puts too much authority in the origins of Biblical lexts. Historical-criticism therefore misses what is most enduring and engaging about the language of Scripture - its constant ability to set in molion a panoply of meaning, a depth released in and through the time of its reading community, the church. The notion of revelation developed in chapter one - as an eschatological momentum experienced in and through the church - heightened our critique of the historicist tendency to dismiss the harvest of Scriptural meaning accumulated through time.

The intention of Part II was precisely to reap (only some of) the benefils of 1 Thessalonians' very particular harvest of meaning. Therefore, subsequent to identifying the severe limitations of the historical-critical project, we extracted and displayed elements of the inexhaustible content within 1 Thessalonians. The premodern commentaries of Thomas Aquinas and John Calvin were studied not as historical curiosities, nor as a polite nod to quaint reading practices, but precisely to rc-examine marginalised reading strategies. In addition fresh perspectives on the infinite content within 1 'lhessalonians were acquired. Attention was thus directed to both Thomas' and Calvin's mode of reading, and the results of their reading.

In Thomas' commentary, in particular on 1 Thessalonians 4:13f, Christ acts as a 'hermeneutical axis', 5 the figute around whom Paul's causal way of thinking is to be understood. Linking eschatology to Christology, and both of these to the text, Thomas allows Christ's resurrection itself to be understood anew as a dynamic,

${ }^{3} \mathrm{CD} \mathrm{I} / 2,50$.

${ }^{4}$ McCormack, 1991, 326.

${ }^{5}$ Blowers, 1993, 219, on Miximus the Confessor. 
active power. This commitment in linking (instrumental) Christology to the text was an insight whose steps we would endeavour to follow in Part III. In relation to his exegetical practice it is clear that Thomas was committed to the logic of Scripture, as demonstrated in the richness of his canonically-driven exegesis. In Thomas' exegesis proper attention is given to the providence of God, as the ultimate author and power behind Scripture. Finally, Thomas' commitment to Paul as the author of 1 'Thessalonians is evident in his intricate and sustained division of the text, a method which is a discipline in reading very closely what is actually there in the text, with what the text is saying in reality.

Turning to Calvin, it is apparent that his much-vaunted 'spiritual sobriety' played its part in his reluctance to embrace the amplitude of a canonically led conversation. 6 Calvin stands at the crossroads beiween pre-modernity and modernism: his preference for 'spiritual sobriety' $;$ his evident reluctance to expose 1 Thessalonians to the medley of its wider canonical context; and his marshalling of philological and lexical apparatus in pursuit of Paul's 'meaning' all have clear resonances with the historical-critical drive that developed posterior to Calvin. ${ }^{8} \mathrm{Calvin}$ insisted that it is individanlly possible to acquire the single, true sense of the author's meaning, quite independent of the support offered by the collective memory of tradition. This has obvious links with subsequent, fateful developments in which fixation with historical context takes on the role of a rampart against Scripture's wealth of meaning, ${ }^{2}$ for in many forms of historical-criticism it is assimed that only determined historical-critical attention can free us from the impositions of dogma. Although Calvin is certainly pre-tnodern insofar as he expected to find in his interpretation a deeper understanding of Christ, some of his methods are undoubtedly preludes to future developments. There is, as we had cause to frequently note, a noticeably tense aspect to Calvin's exegetical methods and he reads very much as one on the cusp of modernity.

Calvin's contribution to the reading of 1 Thessalonians is his determination to read the whole of the letter in an eschatological vein. Where Thomas lavishes his attention

\footnotetext{
${ }^{6}$ Comm. 1 Thess. 5:6.

${ }^{7}$ Comm. 1 Thess. 5:6.

${ }^{*}$ Comm. 1 Thess. 4:13.

${ }^{2}$ cf. Thiselton, 1992, 190-4.
} 
on the causality indicated by Paul in 1 Thessalonians 4:13i, Calvin's attention to Paul is evidenced by his reading of the whole of the letter through eschatological lenses. Calvin's balancing out of the future and alteady-present aspects of his eschatology, and his determination to weave this perspective throughout his exegesis of 1 Thessalonians was a legacy we were especially keen to shadow in our final chapter.

Notwithstanding the stated misgivings in relation to aspects of Calvin's methodological bequest, it is apparent that the hermeneutical stances of both Thomas and Calvin challenge historical-critics to re-think what it is really to listen to Paul. For those like Krister Stendahl tidelity to Pat is achieved by putting a maximal distance between ourselves and the historical Paul, ${ }^{10}$ and supposing that we can recover an authorial intention as a trulh 'independent of the one who discovers it. 11 For historical-critics the 'otherness' of Paul is always a historical distance, ${ }^{2}$ and not what he is actually saying in its captivating depth. Both Thomas and Calvin listen carefully to the Paul of 1 Thessalonians. Calvin reads 1 Thessalonians scoped by a vision which creatively switches between the end's current out-working and its transcendence. Thomas pays studied attention to Paul's teaching in 1 Thessalonians 4:14, and demonstrates the potential of using Christ as an exegetical pivot, the figure around whom Paul's witness can be divined. For both Thomas and Calvin 1 Thessalonians is a text through which God is addressing ut, a text whose ultimate centre is the divine iniliative of grace. Thomas' and Calvin's patient engagement with the text (in contrast to the disengagenent so easily practised by historical critics) is a reminder that at the centre of the text, and at the heart of Cluistianity, is the mystery of the divine-human encounter in Christ.

This supreme mystery, miraculously witnessed to in the frailty of Biblical words, ${ }^{13}$ is what we attempled to wrestle with, explore and encounter in the self-consciously Christ-ruled reading of Part III. Taking our cue from both Thomas and Calvin we

\footnotetext{
${ }^{10}$ Stendahl, 1984, 9, 'the more intensive the expectation of normative guidance and the more exacting the claims for the holiness of the Scriptures, the more obvious should be the need for full altention to what it meant in the tine of its conception and what the intention of its authors might have been.'

${ }^{11}$ I outh, 1983, 99.

${ }^{12}$ Dumn, 1995, 358. One frequently finds this completely false-step, that the alien aspect of Paul is his histotical distance, in Biblical scholars: e.g. Stanton, 1977, 68-70.

${ }^{13} C D \mathrm{I} / 2,506-8$.
} 
explored the redemptive imagery of the text, guided by the notion that Scripture is a symbol of the miraculous divine-human encounter revealed in Christ.

In chapter 5 the work of the one who 'died for us' and whose grace continues to transfigure the world was explored by virtue of a fluid conversation with the text, Fathers, and selected thcologians from across the Christian tradilion. We prepared ourselves hermeneutically by turning to the work of Karl Rahner, and his seminal essay, 'The Hermeneutics of Eschatological Assertions.' For Karl Rahner there is a radical truth strelching across the experience of the 'I'hessalonians and for those now who dare to place their hope in God's eschatological vision, for eschatology remains always, in all places, the forward expansion of Christ's gaace experienced in the present. Anything that is said eschatologically, at any time, is always born from the experience of Christ's grace and 'derives from the assertion about the salvific action of God in his grace on actual man'.14 Rahner's hermeneutical manifesto helped us imagine an interpretation of 1 Thessalonians, with its obvious eschatological themes, as a momentum participating in the activity of eschatological grace.

After paying due attention to the integrity of Paul's contribution, and the extent to which 1 'Thessalonians can be read as pointing to the unity of God in Christ's saving action, the richness of the text was expounded so that we might understand the central, and striking, claim of 1 Thessalonians 4:14, namely the resurrection of the dead, and the linking of that resurrection with Christ's resurrection. We deployed a three-fold interpretation of the apostolic claim that Jesus died 'for us' (5:10): that Jesus' death is a demonstration of God's radically complete grace; that Jesus' death discloses God's radical love; and that the death of the Son ignites God's radical exchange. It was this final image of Jesus' death as a reconciling exchange which most adequately prepared us for the final section of chapter five. Here, we consolidated otur argument that a commitment to images offers the best hope of wrestling with Paul's teaching in 1 Thessalonians 4:14.

Numerous images within the text were explored. First, we discerned a theme of transfiguration within the text, a transformation witnessed in the triad of faith, hope and 'God-taught' love (4:9). This theme of transfigturation was extended in our

${ }^{14}$ Ralıner, 'The Hermeneutics', 338 . 
second grouping of images: light (5:5) and continual prayer (5:17). A close connection between the light of Jesus' transfiguration, the light of which we are now, and the light of the parousia was argued for and demonstrated. Thirdly, the image of the 'dead in Christ' (4:16) was explored in its mystical depth, and we argued that it was possible to read this phrase as meaning much more than merely 'dead Christians'. Fourthly, the reference to the 'sleeping' (4:13) Christians was investigated as a symbol of out anticipation of death's climactic defeat. Finally, we examined the image of the parousia itself (4:16-17), reading its symbolism of Christ descending and Christians ascending as a fitting microcosm of the wondrous exchange God reveals in Christ. Returning to the hermeneutical themes of the opening section of this chapler we contended that eschatological existence is a perennially precipitous affair, a balancing out of the future's necessary obscurity and yet present immanence.

\section{(2) The integrity of our hermeneutical conversation}

One of the striking features of Part III was the hermeneutical conversation we attempted to construct and maintain. Stich a conversation was foreshadowed in chapter 1, where we cited David Tracy's dictum that 'neither interpreter nor text but the common subject matter takes over in genuine conversation. ${ }^{\prime 15}$ Building on Part II, Part III's implicit challenge to dominant assumptions within the New Testament guild was that loyalty to Paul is to encounter what he is attempting to communicate, and in that cause to enter into conversalion with Paul's witness.

The question of our particular conversation's integrity is paramount. There can be no evading that although we are committed to the text's liveliness, a liveliness communicated through the church's ruminative reading of 1 'Ihessalonians and of the whole canon, it is I as the author of this thesis who has convened this conversation, and it is I who decided when to give voice to certain traditions, when to draw upon certain perspectives, and when not to draw upon other interpretative insights. In such a scenario there is always the risk or temptation for me to conceal what I am really interested in saying and concluding, and in that pursut raising aloft 'conversation' as an alltring, if ultimately deceptive, chimera.

\footnotetext{
15 Tracy, 1984b, 124.
} 
In our final chapter there always loomed this danger of a closed discourse under the mask of a gentine dialogue. Nevertheless, it is important to recall that the vocation of theology is to articulate a conversation gripped by its subject matter, tolerant of its necessary provisionality, faithful to Scripture's generative capacity, and correspondingly empowered to seek those appropriate spaces and silences into which might be uttered a renewing, transformative voice. ${ }^{16}$ Such a conversation will incleed be doomed to futility or the error of our ways of thinking if it does not retain a liturgical or doxological quality, a commitment to balancing out the language we use about God, and the language we tum back towards God,

'The integrity of a community's langulage about God, the degree to which it escapes its own pressures to power and closure, is ticd to the integrity of the language it directs to God.'17

In the final chapter, whilst acutely aware of the self-delusion that we were having a fluid conversation with the text, we nevertheless held out the hope that a conversation with the text's witness is possible if attention is paid to the crafting of its (the conversation's) integrity. Such integrity is best demonstrated by a genuinely open-ended quality, an awareness that there could always be a response, or a text, or a refinement, or a watchful silence that could suggest new possibilities of understanding. In the end, a conversation's resistance to determinacy or closture is the best guide as to its integrity,

Having intcgrity, then, is being able to speak in a way which allows of answers. Honest discotirse permits response and continuation; it invites collaboration by showing that it does not claim to be, in and of itself, final. It does not seek to prescribe the tone, the direction, or even the vocabtlary of a response. ${ }^{\prime 18}$

As Rowan Williams notes in this seminal essay, 'Theological Integrity', it is the inescapable burden of theological language (precisely because of its subject matter) to hover on the edge of tumbling into a totalising mindset. It is precisely because of

\footnotetext{
16 cf. 'The Jndgement of the World' in Williams, R., 2000a, 29-43 (39-40).

17 'Theological Integrity' in Williams, R., 2000a, 3-15 (7, emphasis original).

18 'Theological Integrity' in Williams, R., 2000a, 3-15 (5),
} 
this danger that theological language, of which our final chapter is a player, must remain responsive to the practices of prayer, penitence and praise. ${ }^{19}$

\title{
(3) Some departing images in relation to theological exegesis
}

Aside from these reflections on the contribution and potential of interpretation understood as conversation, there are two further images that aid thought on the style of exegesis explored in l’art Ill.

Our probing of the images of redemption within 1 Thessalonians suggests that the thesis has developed a certain 'iconic' understanding of Scriptural language. There is certainly precedence in Christian tradition for discerning parallels between icons and the words of Scripture, ${ }^{20}$

\begin{abstract}
'What the word transmits through the ear', that painting silently shows through the image and by these two means, mutually accompanying one another....we receive knowledge of one and the same thing. ${ }^{21}$
\end{abstract}

Both Scripture and the icons of Orthodox devotion are images and representations of the divine truth experienced and encountered, whilst always remaining ineffable and transcendent. Although there is a deep connection between the reality indicated by both Scripture and the icon (the insight of faith is precisely to discern this interweaving of God's will and the world), 'inasmuch as the icon is an image, it cannot be consubstantial with the original; otherwise it would cease to be an image

\footnotetext{
19 'Theological Integrity' in Willians, R., 2000a, 3-15 (8-15). One of the problems which we have not had space to deal with in any theologically adequate way is the question of the misreadings of Scripture's infinite content, and the devastating effects this has had (and does have) on its victims. In relation to our study the interpretation history of 1 Thessalonians 2:14-16 is highly pertinent. Limited space threatens our response with hideous glibness. Nevertheless, it is clear that one of the outcomes of the recent emphasis on the Wirkangsgeschichte of the Bible might be an increase in truthful and penitent confession on the part of the church for damaging readings of the Bible. What is clear is that remorse is a corporate act, a painful recognition on the part of the church of our feilowship with past sinful readers of the Bible, and an cqual identification with the countless groups and individuals that have been damaged by these very same readings. See Williams, R., 2000b, 95-138, 'To acknowledge the past, the past in which I am enmeshed with countless olhers and which I cannot alter by my will, is entirely and unavoidably a risk, an exposure of vulnerability.' (109). See also Räisänen, 1992.

${ }^{20)}$ e.g. Harrison, N.V., 1988.

${ }^{21}$ Acts of the VIIth Ecumenical Council, Act 6. Cited and transiated in Ouspensky, 1982, 30.
} 
and would become the original, would be of one nature with it." ${ }^{\prime 2}$ Just as with the icon, so too in Scripture have we been aware of the acute difference between the form and content of Scriptural pronouncements. ${ }^{23}$

Both the icon and the Scriptural lext, moreover, are invitalions to participale in the incxhaustible grace of God's divine-human encounter, and both are bearers of an infinite depth of meaning and understanding, precisely and only because of what they witness to and signify. Both, read in the light of what they are willing us to cncounter, resist any notion of an exhaustive or definitive interpretation. So too, in both the icon and the Scriptural text there is a bare exterior form (a two-dimensional depiction or some squiggles on a page), with which we must engage prior to entering into the depth of its reference. Pivotal to the Scriptuxal images of redemption we explored in Part III, and to the use of icons in Eastern Christianity, is the notion that we are primarily being invited to participate in the world they propose we imagine,

'The skill of looking at icons, the discipline of 'reading' them, is indeed the strange skill of letting yourself be seen, be read.'24

Attentive readers of both the Scriptural text and icons discern a world being proposed by the imagination of faith. In the 'inverse perspective' of the icon and the divine-human transformation witnessed to in the frailty of the Bible's words, the attentive reader 'stands, as it were, at the start of a pathway which is not concentrated on some point in depth, but which unfolds itself before him in all its immensity.'25 Apprehending that in Scripture we are being addressed, Paul's language is of less interest for what it reveals of his own age, and of far more interest as the communication of an apostle, whose very words are transfigured by their content. ${ }^{26}$ The spatial prepositions employed here bring out the contrasts in relation to historical-critics. Where historical-critics talk of getting behind the text, as if its origins were theologically crucial or the most interesting thing we could say about the lext, our altempl has been to see into the depths of 1 Thessalonians, and so to

\footnotetext{
${ }^{22}$ Ouspensky, $1982,32$.

${ }^{23}$ cf. Rahner, "The Hermeneutics', 344-5.

21 Williams, R., 2000 b, 185.

${ }^{25}$ Ouspelusky, 1982, 41.

20 'Revelation Through Acts, Words and Images' in Stāniloae, 1980, 109-54 (111).
} 
press the text (and indeed ourselves) forwards into an irrepressibly ruminative process.

A second image also aids reflection on the adopled style of Part III. The kind of expansive reading we advocated could be seen to enjoy parallels with Gregory of Nyssa's influential articulation of epectasis: the constant, ceaseless straining forward into yet deeper spiritual truths and experiences. 'This conception of exegesis, as something capable of an inexhaustible fullness, is predicated on the basis of the text's content and reference, for,

the Divine is by its very nature infinite, enclosed by no boundary, ${ }^{\prime 27}$

Theological exegesis, with this understanding of the text, will always be seeking new meanings in which it can temporarily take root, whilst nurturing an expanding network of understanding. In this economy, spiritually attentive readers will constantly be aware of the provisionality of their insights into the text, and will insistently be searching for what is yet deeper and more illuminative. ${ }^{28}$ Precisely because theological exegesis is committed to the depth of 1 Thessalonians it is set on an ever-expanding path of fullness,

'Made to desire and not to abandon the transcendent height by the things already attained, it [the soul] makes its way upward without ceasing, ever through its prior accomplishments renewing its intensity for the flight. '29

Sel on such a course, where the imagination of the world proposed by Scripture is always overtaking us, we are properly gripped, subdued, and inspired by the mim profunditas of Scripture itself, and our hold on meaning is always pregnant with yet more depth,

\footnotetext{
${ }^{27}$ Gregory of Nyssa, Life of Moses, $\$ 236$.

${ }^{28}$ Webster, 1992, 12, 'if Christian faith is a 'work in process', that is because of the abundance of the reality which engenders it.'

${ }^{2 \prime}$ Gregory of Nyssa, Life of Moses, $\$ 226$.
} 
'Like a raging swift-flowing torrent, Sacred Scripture so fills the depths of human tanderstanding that it is always overflowing its banks. It satisfies those who drink from it, and yet it remains umexhausted. From Scripture there flow forth abundant channels of spiritual meaning, and when some meanings pass away, others arise. No, it cannot be that these meanings pass away, since wisdom is immortal. But what happens rather is that when some have emerged to show their beauty, there are others that take their place. This is not to say that the meanings that pass away are wanting. Rather they remain in evidence and follow close behind in a supportive role. This is so that each and every person might, according to his capacity, obtain in Sacred Scripture the means to refresh himself abundantly and so that he might in turn pass on to others the means of undertaking a regime of rigorous training' ${ }^{30}$

To be possessed by this depth of Scripture is to be gripped by a restlessness for,

'one must always, by looking at what he can see, rekindle his desire to see more. Thus, no limit would interrupt growth in the ascent to God, since no limil to the Good can be found nor is the increasing for the Good brought to an end because it is satisfied.'31

Proposing a reading of Scripture open to its spiritual wealth, runs counter to much of the disengaged, fragmented, and atomised style of current theological study. That contemporary theology no longer enjoys a mutually critical and refining relationship with spirituality needs little demonstration.32 A genealngy of this 'collapse of the centre in theology' is quite outside the scope of this concluding sketch, ${ }^{33}$ save to say that this thesis has been partly motivated by dismay at the loss of what Paul Blowers terms (in discussing Maximus the Confessor) an 'integrative vision', 34 a conviction

\footnotetext{
${ }^{30}$ Gilbert of Stunford, In Cant. prol. Cited and translated in De Lubac, [998, 75-6.

31 Gregory of Nyssa, Life of Moses, $\$ 239$.

${ }^{32}$ McIntosh, 1998, 3-38; Louth, 1983, 1-44.

${ }^{33}$ Louth, 1983, 2.

${ }^{34}$ Blowers, 1993. For an outline of the 'integrative vision' of the Fathers see Greer, 1986, 1-18.
} 
that theological rigour, Biblical attention, spiritual noutrishment, and pastoral relevance can only stand together.

Contemporary theological study, with its departments within departments, and its appropriate professional society for each of these sub-disciplines has proven remarkably adept at breaking tp, but noticeably reluctant to consider how these disciplines contribute to a collective wisdom..$^{35}$ In an intellectual context wherc prayerful, spiritual reflection is likely to be typecast as the stuff of 'pious cmotions' (as if personal involvement with God and the intellect were competitive in relationship), ${ }^{36}$ theology needs to be reminded that it is at heart talk about God not merely proposed as an intellectual idea, but encountered as a dynamic mystery,

\begin{abstract}
'Apart from continuing reflection on the transforming encutunter with God, it is easy enough for me as a theologian to forget that the divine 'object' of my study is never simply that but always the living self-disclosing ground of my own understanding. ${ }^{37}$
\end{abstract}

In our call for a restored integrative approach to Biblical study, there is an appeal to combine the skills of the infellect with the mystical and spiritual content of theological utterances. Theological reading of Scripture is thus committed to both the hard work of spelling out the human meanings, the hopes and possibilities, carried in this or that theological atterance', 38 and the worshipping community which places Scripture as its centre of reflection, where 'worship and reflective prayer witness to and deepen the immersion of human acting in God's. ${ }^{39}$

These images with which we have allusively concluded - Scripture as an 'icon' and Scripture as a bottomless well of meaning for spiritually alert readers - remain as images. They remind us that at the heart of all theological endeavour there resides a

\footnotetext{
35 cf. Milbank, 2000 .

${ }^{36}$ McIntosh, 1998, 11. Cf'. Louth, 1978, 12, 'The theologian is one who prays, and one who thinks about the object of his loving prayer."

${ }^{37}$ McIntosh, 1998, 15.

38 'The Unity of Christian Truth' in Williams, R., 2000a, 16-28 (26).

39 'The Unity of Christian Truth' in Williams, R., 2000a, 16-28 (27). 'lhe need for theology to constantly engage with the ljfe of the church is reciprocal. See Lash, 1997, 133, "The combined impact of the dedicated anti-intellectualism of the devout, and the stultifyingly complacent and patronising ignorance of the irreligious, has been devastating.'
} 
divine mystery humbly received with delight and wonder. The reading of 1 Thessalonians proposed in this thesis has strived, in a modest way, to demonstrate the viability and potential of reading the Bible attentive to precisely this generative centre. All theology which attempts to convey this mystery with a sense of exhilaration, must constantly shield ilself from idolatrous tendencies, and so by way of final conclusion, Paul's dictum provides a worthy antidote to the theologian's verbosity,

\footnotetext{
'Anyone who claims to know somelhing docs not yet have the necessary knowledge.' (1 Cor 8:2).
} 


\section{Bibliography}

\section{Classical authors}

Aristotle. On the Soul, Parva Natumlin, On Breath. [Trans1, W.S. Hett]. LCL. London: William Heinemann. 1935.

.On Interpretation. [Transi. J.T. Oesterlel. Milwaukee: Marquette Universily Press. 1962.

\section{Patristics}

Cyril of Alexandria. On the Unity of Christ. [Transl. J.A. McGuckin]. Crestwood: SVSP. 1995.

Commentary on the Gospel According to St John. [Various translators, members of the English Church]. London: Walter Smith. 1885.

Translations of Cyril's works are also drawn from Russell, 2000, and McGuckin, J.A., 1994, for which see below.

Pseudo-Dionysius, the Areopagite. Pseuto-Dionysius: The Complete Works.

[Transl. C. Luibheid]. London: SPCK. 1987.

Athanasius. 'Four Discourses against the Arians' in NPNF'2 IV. [Transl. J.I-I. Newman. Revised A. Robertsonl. Edinburgh: 'I'\&'I' Clark, 303-447. 1891.

'On the Incamation of the Word' in NPNF2 IV. [Transl. A. Robertson]. Edinburgh: T\&T Clark, 31-67. 1891.

'Ad Adelphitum' in NPNF2 IV. [Transl. A. Robertson]. Edinburgh: T\&T Clark, 575-8. 1891.

Augustine. 'On the Trinity' in Basic Writings of Saint Augustine. Volume 2. Ld. W.J.

Oates. [Transl. A.W. Haddan. Revised W.G.T. Shedd]. New York: Random Iouse, $665-878.1948$. 
'Eight Questions of Dulcitius' in Saint Algustine: Treatises on Various Subjects. Ed. R.J. Deferrari. [Transl. M.S. Muldowney inter alios]. FOC 16. Washington: CUAP, 427-66. 1952.

'Tetter 199' in Saint Augustine. Letters: Volume IV (165-203). [Transl. W. Parsons], FOC 30. Washington: CUAP, 356-401. 1977.

.The City of God against the Pagans. [Transl. R.W. Dyson]. Cambridge: CUP. 1998.

John Damascene. 'Homily on the Transfiguration of Our Lord Jesus Christ by Saint John of Damascus.' [Transl. H.L. Weatherby]. GOTR 32 (1987), 1-29. 'Exposition of the Orthodox Faith.' [Transl. S.D.F. Salmond]. NPNF² IX. Edinburgh: T\&T Clark, 1-101. 1898.

Maximus the Confessor. On the Cosmic Mystery of Jesus Christ: Selected Writings from St Maximus the Confessor. [Transl. P.M. Blowers \& R.L. Wilken]. Crestwood: SVSP. 2003.

Translations of Maximus' works are also drawn from Louth, 1996, for which see below.

Gregory Nazianzen. 'Select Orations.' [Transl. C.G. Browne \& J.E. Swallow]. NPNF2 VII. Edinburgh: T\&T Clark, 203-434. 1893.

Gregory Nyssen. The Calechelical Oration. [Trans1. J.H. Srawley]. London: SPCK. 1917. $\therefore$ 'An Address on Religious Instruction' in Christology of the Later Fathers. [Ed. \& transl. E.R. Hardy in collaboration with C.C. Richardson]. London: SCM, 268325. 1954.

.The Life of Moses. [I'ransl. A.J. Malherbe \& E. Ferguson]. New York: Pautlist Press. 1978.

'Against Eunomius.' [Transl. W. Moore \& H.A. Wilson]. NPNF2 V. Edinburgh: T\&'T Clark, 33-239. 1892.

'On the Soul and Resturrection.' [Transl. W. Moore \& H.A. Wilson]. NPNF2 V. Edinburgh: 'T\&'T' Clark, 430-468. 1892.

Translations of Gregory Nyssen's works are also drawn from Daniélou, 1962, for which see below. 
Origen. 'On Prayer' in Origen. [Transl. R. Greer]. London: SPCK, 81-170. 1979.

'Commentary on Matthew.' [Transl. J. Patrick]. ANF X. New York: Christian Literature Company, 413-512. 1897.

Gregory Palamas. The Triads. [Transl. N. Gendle]. Mahwah: Paulist Press. 1983. A translation of Gregory's work is also contained in Rogich, 1988, for which see below.

\section{Thomas Aquinas}

\section{(i) Primary sources}

Super Evangelium S. Ioannis Lectwa. Ed. P.R. Cai. Turin: Marietti. 1952.

Super Epistolas S. Pauli Lechura. Volume 2. Ed. P.R. Cai. Turin: Marietti. 1953.

\section{(ii) Translations}

The "Stmma Theologica" of St. Thomas Aquinas. Third Parl (Stpplement), QQ LXIX-

LXXXVI. [Transl. Fathers of the English Dorninican Province]. London: Burns Oates and Washbourne. 1921.

Compendium of Theology. [TransL. C. Vollert]. St Louis: Herder. 1962.

Summa Theologiae. Vols. 1-60. Ed. T. Gilby and T.C. O'Brien. [Various translators].

London/New York: Blackfriars. 1964-73.

Commentary on St. Paul's Epistle to the Ephesians. [Transl.M.L. Lamb]. Albany, NY:

Magi Books. 1966. (Cited as Lamb, 1966).

Commentary on Saint Panl's First Letter to the Thessaloninns. [Transi. M. Duffy]. Albany:

Magi Books. 1969. (Cited as Duffy, 1969).

Commentary on the Gospel of St. John. Vol. I. [Transl. F.R. Larcher]. Albany: Magi

Books. 1980. (Cited as Larcher, 1980).

Commentary on the Metaphysics of Aristotle. [Transl. J.P. Rowan]. 2 vols. Chicago: Henry Regnery Company.

\section{Medieval Theology}

\section{(i) Pximary Sources}

Peter Lombard. In Omnes D. Pauli Apoft. Epiftolas Collectanea. Paris. 1537. 


\section{(ii) Translations}

Anselm of Canterbury. 1956. 'Why God Became Man' in A Scholastic Miscellany: Anselm to Ockham. [Ed. \& transl. E.R. Fairweather]. London: SCM, 100-183.

\section{John Calvin}

\section{(i) Primary Sources}

Ioannis Calvini opera qune supersunt omnia. Eds. W. Baum, $\mathbf{E}$. Cunitz \& E. Reuss.

Volume 52. Brunsvigae: C.A. Schwetscke, 1863-1900. Vols: 29-98: Corpus Reformatorum.

\section{(ii) Translations}

Institutes of the Christian Religion. Ed. J.T. McNeill. [Transl. F.L. Battles.] Philadelphin: Westminster Press. 1960.

Commentaries of John Calvin. 1843- Edinburgh: Calvin Translation Sociely:

Commentary on the Book of Psalms. [Transl. J. Anderson]. Volume 1. 1845;

Commentaries on the Book of Genesib. [Transl. J. King]. Volume 1. 1847;

Commentaries on the Prophet Ezekiel. [Transl. 'T. Myers]. Volume 1. 1849;

Commentaries on the Four Last Books of Moses. [Transl. C.W. Bingham]. Volume

1. 1852; Commentary on the Prophet Isaiah. [Transl. W. Pringle]. Volume 3. 1852;

Commentaries on the Book of the Prophet Jeremiah and the Lamentations. [Transl. J.

Owen]. Volume 5. 1855.

Caloin's Commentaries. 1960 - Eds. D.W. Torrance \& T.F. Torrance. Edinburgh: Saint

Andrew Press/Oliver and Boyd: The Gospel According to St John 1-10. [Transl.

T.H.L. Parker]. 1959; The First Epistle of Panl the Apostle to the Corinthians.

[Transl. J.W. Fraser]. 1960; The Epistles of Paul the Apostle to the Romans and to the Thessalonians. [Transl. R. Mackenzie]. 1961; The Epistle of Paul the Apostle to the Hebrews and the First and Second Epistles of St. Peter. [Transl. W.B. Johnston]. 1963; The Second Epistle of Paul the Apostle to the Corinthians and the Epistles to Timothy, Titus and Phitemon. [Trans1. T.A. Smail]. 1964; The Epistles of Paul the Apostle to the Galatians, Ephesians, Philippians and Colossians. [Trans]. T.Y.L. Parker]. 1965; A Harmony of the Gospels: Matthew, Mark and Luke. Volume 1. [Transl. A.W. Morrison], 1972.

'Psychopannychia' in Tracts and Trentises in Defence of the Reformed Faith. Volume III. 
[Transl. H. Beveridge]. Edinburgh: Oliver and Boyd, 413-90. 1958.

'Calvin's Reply to Sadoleto' in A Reformation Debate: Sadoleto's Letter to the Genevans and Calvin's Reply. Ed. J.C. Olin. [Transl. I-I. Beveridge]. New York: Harper Torchbooks, 49-94. 1966.

\section{Martin Luther}

\section{(i) Translation}

'Two Funeral Sermons, 1532.' [Ed. \& transl. F.W. Doberstein]. Luther's Works. Volume 51. Philadelphia: Mulhlenberg Press, 231-55. 1959.

\section{Karl Rahner}

(i) Monographs

1961. On the Theology of Death. [Transl. C.F. Henkey]. Freiburg: Herder. 1978. Foundations of Christion Faith. [1'ransl. W.V. Dych]. London: DLT. 1985. I Remember. [Transl. II.D. Egan]. London: SCM.

\section{(ii) Articles from Theological Investigations}

There are various translators for this series published in London by DLT and in Baltimore by Helicon Press (1961-1992) from the German original, Sclviften zur Theologie (Einsiedeln: Benziger, 1954-1984). Dates in parentheses are the date of publication in English translation.

'Current Problems in Christology', TI i, 149-200 (1961)

'The Resurrection of the Body', TI ii, 203-16 (1963)

'The Hermeneutics of Eschatological Assertions', TI iv , 323-46 (1966)

'The Life of the Dead', TI iv, 347-54 (1966)

'Thoughts on the Possibility of Belief 'Today', T/ v, 3-22 (1966)

"Christianity and the "New Man', TI v, 135-53 (1966)

'On Christian Dying', TI vii, 285-93 (1971)

'Ideas for a 'Theology of Childhood', TI viii, 33-50 (1971) 
'Christian Humanism', TI ix, 187-204 (1972)

'A Fragmentary Aspect of a Theological Evaluation of the Concept of the Future', TI $x, 235-41(1973)$

'Tumanent and Transcendent Constmmation of the World', T7 x, 273-89 (1973)

'Theological Observations on the Concept of Time', TI xi, 288-308 (1974)

'The Question of the Future', TI xii, 181-201 (1974)

'Jesus' Resurtrection', TI xvii, 16-23 (1981)

'The Body in the Order of Salvation', TI xvii, 71-89 (1981)

'The Death of Jesus and the Closure of Revelation', TI xviii, 132-42 (1983)

'Christian Dying', TI xviii, 226-56 (1983)

\section{Secondary Literature}

Abraham, W.J. 1982. Divine Revelation and the Limits of Historical Criticism. Oxford: OUP.

Adam, A.K.A. 1995. Making Sense of New Testament Theology: 'Modern' Problems and Prospects. Macon: Mercer University Press.

Aertsen, J.A. 1993. 'Aquinas's Philosophy in its Historical Setting.' Eds. N.

Kretzmann \& E. Stump. The Cambridge Companion to Aquinas. Cambridge: CUI, 12-37.

Albertson, J.S. 1954. 'Instrumental Causality in St. Thomas.' New Scholasticism 28, 40935 .

Allchin, A.M. 1988. Participation in Gnd: A Forgotten Strand in Anglican Tradition. Londion: DLT.

Anderson, R.S. 1986. Theology, Death and Dying. Oxford: Basil Blackwell.

Astley, J. 1980. 'Revelation revisited.' Theology 83, 339-46.

Aulén, G. 1931. Christus Victor. [Transl. A.G. Hebert]. London: SPCK.

Baglow, C.T. 2002. "Modus et Foma": A New Approach to the Exegesis of Saint Thomas with an Application to the Lectura super Epistolam ad Ephesios. Rume: Editrice Pontificio Istituto Biblico.

Baillic, J. 1956. The Idea of Revelation in Recent Thought. New York: Columbia University Press. 
Baldner, S. 1983. 'The Use of Scripture for the Refutation of Error According to St.

'Thomas Aquinas.' Eds. D.V. Stump et al. Hamartin: The Concept of Eror in the Western Tradition. New York: Edwin Mellen Press, 149-69.

Barclay, J.M.G. 1992. 'Thessalonica and Corinth: Social Contrasts in Pauline

Christianity.' JSNT 47, 49-72.

.1993. 'Conflict in Thessalonica.' CBQ 55, 512-530.

1995. 'Paul Among Diaspora Jews: Anomaly or Apostate?’ JSNT 60, 89-120.

.Forthcoming. "That you may not grieve, like the rest who have no hope...."

(1 Thess 4:13): Death and Early Christian Identity.'

Barr, J. 1996. 'Allegory and I Iistoricism.' JSOY' 69, 105-20.

.1999. The Concept of Biblical Theology: An Old Testament Perspective. London: SCM.

Barth, K.1933a. The Epistle to the Romans. [Transl. E.C. Hoskyns]. 2nd edition. Oxford: OUP.

.1933b. The Resurrection of the Dend. [Transl. H.J. Stenning]. London: Hodder and Sloughton.

1936. 'Revelation' in God in Action: Theolugical Addresses. [Transl. E.C. Homrighausen \& K.J. Ernst]. Edinburgh: T\&T Clark, 3-19.

.1937. 'Revelation.' [Transl. J.O. Cobham \& R.J.C. Gutteridge]. Eds. J. Baillie \& H. Martin. Revelation. London: Faber and Faber, 41-81.

.1954. 'The Christian Understanding of Revelation' in Against the Stream: Shorter Post-War Writings 1946-52. [Transl. S. Godman; Ed. R.G. Snith]. London: SCM, 203-40.

1956. Christ and Adam: Man and Humonity in Romans 5. [Transl. T.A. Smail]. S]T Occasional Papers No.5. Edinburgh: Oliver and Boyd.

.1956-69. Church Dogmatics. [Various translators. Eds. G.W. Bromiley \& T.F. Torrance]. Edinburgh: T\&T Clark: volumes $1 / 1, \mathrm{I} / 2, \mathrm{III} / 2, \mathrm{IV} / 1$.

.1957. The Word of Gud and the Word of Man. [Transl. D. Horton]. New York: Harper \& Row.

.1961. 'The Humanity of God' in The Humanity of God. ['l'ransl. J. Newton Thomas]. London: Coltins, 33-64.

.1962. 'Rudolf Bultmann - An Altempt to Understand Him.' [Transl. R.H. Fuller]. Ed. II.-W. Bartsch. Kerygma and Myth: A Theological Debate. Volume 2. London: SPCK, 83-132. 
1963. Evangetical Theology. ['Transl. G. Foley]. London: Weidenfeld and Nícolson.

1991. The Göttingen Dogmatics: Instructions in the Christian Religion. [Ed. H. Reiffen. Transl. G.W. Bromiley]. Volume 1. Grand Rapids: Eerdmans.

.1995. The Theology of John Calvin. [Transl. G.W. Bromiley]. Grand Rapids: Eerdmans.

.2002. Epistle to the Philippians. [Transl. J.W. Leitch]. Louisville: Westminster John Knox Press.

Barthes, R. 1977. 'The Death of the Author' in Image-Music-Text. [Transl. S. Heath].

London: Fontana Press, 142-8.

Barton, J. 1998. 'Historical-critical approaches.' Ed. J. Barton. The Cambridge

Companion to Biblical Interpretation. Cambridge: CUP, 9-20.

Barton, S.C. 1999. 'New Testament Interpretation as Performance.' SIT 52, 179-208.

Bassler, J.M. (ed.) 1991a. Pauline Theology, Volume I: Thessalonians, Philippians,

Galatians and Philemon. Minneapolis: Fortress Press.

1991b. 'Peace in all Ways: Theology in the Thessalonian Letters.' Ed. J.M. Bassler. Pauline Theology, Volume I: Thessalonians, Philippians, Galatians and Philemon. Minneapolis: Fortress Press, 71-85.

Battenhouse, R.W. 1948. "The Doctrine of Man in Calvin and in Renaissance

Platonism.' Journal of the History of Ideas 9, 447-71.

Battles, F.I. 1996. 'Calvin's Humanistic Education.' Ed. R. Benedetto. Interpreting John Calvin. Grand Rapids: Baker Books, 47-64.

Best, E. A. 1955. One Body in Christ: A Situdy of the Relationship of the Church to Christ in the Epistles of the Apostle Paul. London: SPCK.

1972. Commentary on the First and Second Epistles to the Thessalonins. BNTC. London: A. \& C. Black.

Bieterthard, II. 1953. 'The Millemial Hope in the Early Church.' SIT 6, 12-30.

Black, C.C. 1986. 'St. Thomas' Commentary on the Johannine Prologue : Some Reflections on Its Character and Implications.' CBQ 48, 681-98.

Blanchette, O. 1964. 'Saint Cyril of Alexandria's Idea of the Redemption.' Sciences Ecclésiastiques 16, 455-80.

Blondel, M. 1964. 'History and Dogma' in The Letter on Apologetics, and, History and Dogma. [Transl. A. Dru \& I. 'Trethowan]. London: Harvill Press.

Blowers, P.M. 1991. Exegesis and Spiritual Pedagugy in Maximus the Confessor: An 
Investigation of the "Qunestiones ad Thalassitum". Notre Dame: University of Notre Dame Press.

.1993. 'Theology as Integrative, Visionary, Pastoral: The Legacy of Maximus the Confessor.' Pro Ecclesia 2, 216-30.

.2001. 'The Passion of Jesus Christ in Maximus the Confessor: A Reconsideration.' Eds. M.F. Wiles \& E.J. Yarnold. SP 37. Leuven: Peeters, 36177.

.2002. 'The World in the Mirror of Holy Scripture: Maximus the Confessor's Short Hermeneutical Treatise in Ambigum ad Joannem 37.' Ed. P.M. Blowers et al. In Dominico Eloquio - In Lordly Eloquence: Essays on Patristic Exegesis in Honor of Robert Louts Wilken. Grand Rapids: Ferdmans, 408-26.

Blumberg, H. 1983. 'The Problem of Immortality in Avicenna, Maimonides and St.

'Thomas Aquinas.' Ed. J.I. Dienstag. Eschatology in Mainonidean Thought: Messianism, Resurrection and the World to Conte. New York: Klav Publishing House, 76-96.

Bockmuehl, M. 1995. 'A Commentator's Approach to the 'Effective ITistory' of Philippians.' JSNT 60, 57-88.

1998. "To Be or Not to Be': The Possible Futures of New Testament Scholarship.' SIT 51, 271-306.

Boff, C. 1991. 'Termeneutics: Constitution of 'Theological Pertinency.' Ed. R.S.

Sugirtharajah. Voices from the Margin: Interpreting the Bible in the Third World. London: SPCK, 9-36.

Bonhoeffer, D. 1966. Christology. [Transl. J. Bowden], London: Collins.

Botwsma, W.J. 1982. 'Calvin and the Renaissance Crisis of Knowing:' C'1] 17, 190211.

.1988. John Calvin: A Sixteenth Century Portmit. New York: OUP.

.1990. 'Calvinism as Renaissance Artifact.' Ed. T. George. Calvin and the Church: A Prism for Reform. Lotisville: Westminster John Knox Press, 28-41.

Boyle, J.F. 1995. 'St 'Thomas Aquinas and Sacred Scripture.' Pro Ecclesia 4, 92-104.

Breck, J. 1992. 'Divine Initiative: Salvation in Orthodox Theology.' Eds. J. Meyendorff \& R. Tobias. Salvation in Christ: A Lutheran-Orthodox Dialogue. Minneapolis: Augsburg Press, 105-20.

Breen, Q. 1968. John Culvin: A Study in French Humanism. 2nd edilion. Hamden: Archon Books. 
Bria, I. 1981. 'The Creative Vision of D. Stanniloae: $\Lambda \mathrm{n}$ introduction to his theological thought.' The Ectmenicnl Review 33, 53-9.

Brown, D. 1985. The Dizine Trinity. London: Duckworth. 1994. 'Did Revelation Cuase?' Ed. A.G. Padgett. Renson and the Christian Religion: Essays in Honour of Richard Swinburne. Oxford: Clarendon Press, 12141.

1999. Tradition and Inagination: Revelation and Change. Oxford: OUP.

.2000. Discipleship and Inngination: Christian Tradition and Truth. Oxford: OUP.

Brown, R.M. 1961. "Tradition" as a Problem for Protestants.' USQR 16, 197-221.

Brtuce, F.F. 1982. I and 2 Thessalonians. WBC. Waco: Word Books.

Buehrer, R.L. 1974. John Calvin's Humanistic Appronch to Church History. Unpublished PhD Thesis, University of Washington.

Bulgakov, S. 1935. 'The Church as Tradition' in The Orthodox Church. [Transl. E.S.

Cram]. London: The Centenary Press, 18-47.

.1937. 'Revelation.' [Transl. D.F. Clarke \& X. Braikevilch]. Eds. J. Baillie \& H. Martin. Revelation. London: Faber and Faber, 125-80.

Bultmann, R. 1965. Theology of the New Testament. [Transl. K. Grobel]. Volume 1. London: SCM.

Burke, S. 1998. The Death and Retum of the Author: Criticisw and Subjectivity it Barthes, Foucault and Derrida. $2^{\text {nd }}$ edition. Edinburgh: Edinburgh University Press.

Burnett, R.E. 2001. Kart Barth's Theological Exegesis. Tübingen: Mohr Siebeck.

Callan, C.J. 1947. 'The Bible in the Sunmo Theologicn of St. Thomas Aquinas.' CBQ 9, $33-47$.

Chadwick, II. 1951. 'Eucharist and Christology in the Nestorian Controversy.' ITS N.S. $2,145 \div 64$.

Chamberas, P.A. 1970. 'The Transfiguration of Christ: A Study in the Patristic Exegesis of Scripture.' SVTQ 14, 48-65.

Chenu, M.D. 1964. Toward Understanding St. Thonas. [Transl. A.-M. Landry \& D. Hughes]. Chicago: Henry Regnery Press.

Childs, B.S. 1964. 'Intexpretation in Faith: The Theological Responsibility of an Old Testament Commenlary.' Interpretation 18, 432-49.

1970. Biblical Theology in Crisis. Philadelphia: Westminster Press. 
.1977. 'The Sensus Liseralis of Scripture: An Ancient and Modern Problem.'

Eds. I-I. Doner, R. Hanhart \& R. Smend. Beitrüge zur Alttestamentichen Theologie: Festschrift fiir Walther Zimmerti stm \%. Geburtstag. Göttingen: Vandenhoeck and Ruprecht, 80-93.

.1995. 'Reclaiming the Bible for Christian Theology.' Eds. C.E. Braaten \& R.W. Jenson. Raclaining the Bible for the Chttch. Edinburgh: T\&T Clark, 1-17.

.1997. 'Toward Recovering Biblical Exegesis.' Pro Ecclesia 6, 16-26.

Compier, D.H. 1992. 'The Independent Pupil: Calvin's Transformation of Erasmus' Theological Hermeneutics.' WTJ 54, 217-33.

Congar, Y.M. 1966. Tradition and Traditions. [Transl. M. Naseby \& T'.

Rainborough].London: Burns and Oates.

Cooper, C. 1970. 'Chiliasm and the Chiliasts.' RTR 29, 11-21.

Copeland, R. 1993. 'Rhetoric and the Politics of the Literal Sense in Medieval Literary Theory: Aquinas, Wyclif, and the Lollards.' Eds. P. Boitani \& A. Torti. Interpretation: Medieval and Modern. Cambridge: D.S. Brewer, 1-23.

Cousar, C.B. 1990. A Theology of the Cross: The Death of Jestus in the Panline Letters. Minneapolis: Fortress Press.

Crotty, N. 1962. 'The Redemptive Role of Christ's Resurrection.' The Thomist 25, 54106.

Crouzel, H. 1989. Origen. [Transl. A.S. Worra1]. Edinburgh: T\&T Clark.

Crowley, P.G. 1991. 'Instrumentum Diwinitatis in Thomas Aquinas: Recovering the Divinity of Christ:' TS $52,451-75$.

Cullmann, 0.1958 . Immortality of the Soul or Resurrection of the Dend? The Witness of the New Testament. London: Epworth Press.

Daley, B.F. 1991. The Hope of the Eanly Church: A Handbook of Patristic Eschatology. Cambridge: CUP.

Dalferth, I.U. 1989. 'Karl Barth's eschatological realism.' Ed. S.W. Sykes. Karl Barth: Centenary Essays. Cambridge: CUP, 14-45.

.1991. 'Christ Died for Us: Reflections on the Sacrificial Language of Salvation.' Ed. S.W. Sykes. Sacrifice and Redemption: Durham Essays in Theology. Cambridge: CUP, 299-325.

Daniélou, J. 1962. From Glory to Glory: Texts from Gregory of Nyssa's Mystical Writings. 
[Selection \& Introduction J. Daniélou. Transl. H. Musurillo]. London: John Murray.

Davies, P.R. 1995. Whose Bible is it Anyway? JSOTStu 204. Sheffield: Sheffield Academic Press.

Davies, R.E. 1946. 'Calvin' in The Problem of Authority in the Continental Reformers. London: Epworth Press, 93-153.

De Lubac, H. 1998. Medievat Exegesis. Volume I: The Four Senses of Scripture. ['Transi. M. Seband. Edinburgh: T\&T Clark.

De Vos, C.S. 1999. Church and Community Conflicts: The Relationships of the

Thessalonian, Corinthian, and Philippian Churches with Their Wider Civic Communities. SBLDS 168. Atlanta: Scholars Press.

Dibelius, M. 1937. An die Thessalonicher I, II; An die Philipper. Tübingen: J.C.B.

Mohr.

Dobbs-Weinstein, I. 1989. 'Medieval Biblical Commentary and Philosophical Inquiry as Exemplified in the Thought of Moses Maimonides and St. Thomas Aquinas.' Ed. E.L. Ormsby. Moses Maimonides and His Time. Washington: CUAP, 101-20.

Donfried, K.P. 1985. 'The Cults of Thessalonica and the Thessaloniart Correspondence'. NTS 31, 336-356.

.1993. 'The Theology of 1 Thessalonians' in K. P. Donfried \& I.H. Marshall, The Theology of the Shorter Pauline Letters. Cambridge: CUP, 1-79.

1996. 'The Assembly of the Thessalonians: Reflections on the Ecclesiology of the Earliest Christian Letter.' Eds. R. Kampling \& T. Soding. Elklesiologie des Neten Testaments: Für Kanl Kertelge. Herder: Freiburg, 390-408. .2002. Paul, Thessalonica, and Enrly Christimity. London: T\&T Clark.

Donfried, K.P. \& Beutler, J. 2000. (eds.) The Thessalonians Debate: Methodological Discord or Methodological Synthesis? Grand Rapids: Eerdmans.

Dowey, E.A. 1994. The Knowledge of God in Calvin's Theology. Expanded edition. Grand Rapids: Eerdmans.

Dratsellas, C. 1975. 'Questions on Christology of St Cyril of Alexandria.' (sic.) Abba Salama 6, 203-32.

Dunn, J.D.G. 1991. 'Paul's Understanding of the Death of Jesus as Sacrifice.' Ed. S.W, Sykes. Sacrifice and Redemption: Duham Essays in Theology. Cambridge: CUP, 35-56. 
1995. 'Historical Text as Historical Text: Some Basic Hermeneutical Reflections in Relation to the New Testament.' Eds. J. Davies, G. Harvey \& W.G.E. Walson. Words Remembered, Texts Renewed: Essays in Honour of J.F.A. Sawyer. JSOTSup 195. Sheffield: Sheffield Academic Press, 340-59.

.1996. 'The Bible in the Church.' Fds. D.F. Ford \& D.L. Stamps. Essentials of Christinn Communty: Essays for Daniel W. Hardy. Edinburgh: T\&T Clark, 11730.

Eagleton, T. 1996. Literary 1heory: An Introduction. $2^{\text {nd }}$ edition. Blackwcll: Oxford.

Eco, U. 1992. 'Between author and text' in Eco et al. Interpretation and

Overinterpretation. Fd. S. Collini. Cambridge: CUP, 67-88.

Edgar, T.R. 1979. 'The Meaning of "Sleep" in 1 Thessalonians 5:10.' JETS 22, 345-9.

Edson, C. 1948. 'Cults of Thessalonica.' HTR 41, 153-204.

Elders, L.J. 1990. 'Aquinas on Foly Seripture as the Medium of Divine Revelation.'

Ed. L.J. Elders. La doctrine de la révélation dioine de saint Thomas d'Aquin. Vatican: Pontificia Accademia di S. Tommaso e di religione Cattolica, 132-52.

Engel, M.P. 1988. John Calvin's Perspectival Anthropology. Atlanta: Scholars Press.

Eschmann, I.T. 1957. 'A Catalogue of St. Thomas' Work' in Gilson, E., The Christinn Philosophy of St. Thonas Aquinas. [Transl. L.K. Shook]. London: Victor Gollancz, 381-437.

Farrar, F.W. 1884. 'Calvin as an Expositor.' The Expositor 7 (2nul Series), 426-44.

Fee, G.D. 2002. 'St Paul and the Incarnation: A Reassessment of the Data.' Eds. S.T.

Davis, D. Kendall \& G. O'Collins. The Incamation: an Interdisciplinzary Sympositum on the incartation of the Son of God. Oxford: OUP, 62-92.

Fitzmyer, J.A. 1975. 'Reconciliation in Pauline Theology.' Eds. J.W. Flanagan \& A.W.

Robinson. No Famine in the Land: Studies in Honor of John L. McKenzie. Claremont: Scholars Press, 155-77.

Florovsky, G. 1951. 'The Lamb of God.' SJT 4, 13-28.

.1953. 'On the Tree of the Cross.' SVSQ 1, 11-34.

1972. Bible, Church, Tradition. Collected Works, Vol. I. Belmont: Nordland.

Forstman, I-J.J. 1962. Word and Spirit: Calvin's Doctrine of Biblical Authority. Stanford: Stanford University Press. 
.1986. 'Coherence and Incoherence in the Theology of John Calvin.' Ed. J.H.

Leith. Calvin Studies III. Davidson: Davidson College, 47-62.

Fowl, S.E. 1998. Engaging Scripture: A Model for Theological Interpretation. Oxford: Blackwell.

Frame, J.E. 1912. A Critical and Exegetical Commentary on the Epistles of St Paul to the Thessalonians. ICC. Edinburgh: T\&T Clark.

Froehlich, K. 1991. 'Church IHistory and the Bible.' Eds. M.S. Burrows \& P. Rorem. Biblical Hermenautics in Historical Perspective: Studies in Honor of Karlfried Froehlich on his Sixtieth Birthday. Grand Rapids: Eerdmans, 1-15.

.1996. 'Which Paul? Observations on the Image of the Apostle in the IFistory of Biblical Exegesis.' Ed. B. Nassif. New Perspectives on Historical Theology: Essays in Memory of John Meyentorff. Grand Rapids: Ferdmans, 279 99.

.1998. 'Aquinas, Thomas.' Ed. D.M. McKim. Historical Handbovk of Major Biblical Interpreters. Downers Grove: Inter Varsity Press, 85-91,

Fullerton, K. 1919. 'The Reformation Principle of Exegesis and the Initial Breakdown of the Theory of Predictive Prophecy: Calvin' in Prophecy and Authority: A Study in the History of the Doctrine and interpretation of Scripture. Macmillan: New York, 133-64.

Gadamer, H.G. 1975. Truth and Method. [Transl. W. Glen-Doepel]. London: Sheed and Ward.

.1976. 'The Universality of the Hermeneutical Problem' in Philosophical Hernteneutics. [Transl. D.E. Linge]. Berkeley: University of California Press, 317.

Gamble, R.C. 1988. 'Calvin's Theological Method: Word and Spirit, A Case Study.'

Ed. R.V. Schnuckner. Calviniana: Ideas and Inffuence of John Calvin. Kirksville: Sixleenth Century Journal Publishers Inc., 63-75.

1992a. 'Brevitas et Facilitas: Toward an Understanding of Calvin's ITermeneutic.' F.d. R.C. Gamble. Calvin and Hermenentics. New York: Garland Press, 33-49.

.1992b. 'Exposition and Method in Calvin.' Ed. R.C. Gamble. Calvin and Hermeneutics. New York: Garland Press, 51-63.

Gaventa, B.R. 1998. First and Second Thessalonians. Interpretation. Louisville: John Knox Press. 
Geenan, G. 1952. 'The Council of Chalcedon in the Theology of St. Thomas.' Eds. the Staff of The Thomist. From an Abundant Spring: The Walter Farrell Memorial Volume of The Thomist. New York: P.J. Kennedy \& Sons, 172-217.

Gerrish, B.A. 1982. 'The Word of God and the Word of Scripture: Luther and Calvin on Biblical Authority' in The Old Protestantism and the New: Essays on the Reformation Heritage. Edinburgh: T\&T Clark, 51-68.

Gillette, G. 1997. 'The Glory of Christ's Second Coming in Augustine's Enarrationes in psalmos.' Ed. E.A. Livingstone. SP 33. Leuven: Pecters Press, 88-93.

Gilson, E. 1955. History of Christinn Philosophy in the Middle Ages. London: Sheed and Ward.

Grayston, K. 1990. Dying, We Live: A New Enquiry into the Death of Christ in the New Testament. London: DLT.

Green, J.B. \& Turner, M. (eds.). 2000. Between Two Ilorizons: Spanning New Testament Studies and Systematic Theology. Grand Rapids: Eerdmans.

.2001. 'Modernity, History and the 'Theological Interpretation of the Bible.' SJT 54, 308-29.

Greer, R. 1986. Broken Lights and Mended Lives: Theology and Contmon Life in the Early Church. University Park: Pennsylvania State University Press.

Grecne-McCreight, K. 1994. Ad Litteram: Linderstandings of the Plain Sense of Scriplure in the Exegesis of Augustine, Cnivin and Barth of Genesis 1-3. PhD Thesis, Universily of Yale.

Gunton, C. 1995. A Brief Theology of Revelation. Edinbutgh: T\&T Clark.

Hall, B. 1956. John Calvin: Humanist and Theologian. London: The Historical Association.

.1992. 'Calvin and Biblical Humanism.' Ed. R.C. Gamble. Infutuces upon Cnlvin and Discussion of the 1559 mstitules. New York: Garland Press, 55-69.

Hansen, G.W. 1993. 'Rhetorical Criticism.' Eds. G.F. Hawthorne, R.P. Martin \& D.G.

Reid. Dictionary of Pat and His Letters. Downers Grove: Inter Varsity Press, $822-6$.

Hanson, R.P.C. 1959. Allegory and Event: A Study of the Sources and Significance of Origen's Interpretation of Scripture. London: SCM.

Harbison, E.H. 1956. 'Calvin' in The Christian Scholar in the Age of the Reformation. 
New York: Charles Scribner's Sons, 137-64.

.1964. 'Calvin's Sense of History' in Christimity and History. Princeton: Princeton University Press, 270-88.

Harrison, J. R. 2002. 'Paul and the Imperial Gospel at Thessaloniki.' JSNT 25, 71-96.

Harrison, N.V. 1988. 'Word as icon in Greek patristic theology.' Sobornust 10, 38-49.

.1997. 'Theosis as Salvation: An Orthodox Perspective.' Pro Ecclesin 6, 429-443.

Hart, T. 1989. 'Fumankind in Christ and Christ in Humankind: Salvation as

Participation in our Substitute in the Theology of John Calvin.' SJT 42, 67 -84.

Hausherr, I. 1978. The Nane of Jesus. [Trans]. C. Cummings]. Kalanazoo:

Cistercian Publications.

Hazlett, W.I.P. 1991. 'Calvin's Latin Preface to His Proposed French Edition of

Chrysostom's I-Tomilies: Translation and Commentary.' Ed. J. Kirk. Humanism and Reform: The Church in Furope, England, and Scotland, 1400-1643. Oxford: Blackwell, 129-50.

Healy, N.M. 2003. Thomas Aquinas: Theologian of the Christian Life. Aldershot: Ashgate. Hendrix, H.I.. 1984. 'Thessalonicans Honor Romans.' Unpublished ThD dissertation, Farvard Universily.

1991. 'Axchaeology and Eschatology at Thessalonica.' Ed. B.A. Pearson. The Future of Early Christianily; Essays in Honor of Helnut Kouster. Minneapolis: Fortress Press, 107-1:18.

Tengel, M. 1981. The Atonement: The Origins of the Doctrine in the New Testament.

[Transl. J. Bowden]. London: SCM.

Henle, R.J. 1956. Saint Thomas and Platonisnt: A Study of the Plato and Platonici Texts in the Writings of Snint Thomas. Martinus Nijhoff: The Hague.

Hill, C.E. 1992. Regnum Caelorum; Patterns of Future Hope in Early Christianity. Oxford: Clarendon l’ress.

Holtz, T. 2000. 'On the Background of 1 Thessalmians 2:1-12.' Eds. K.P. Donfried \& J. Beutler. The Thessalonians Debnte: Methodological Discord or Methodological Synthesis? Grand Rapids: Eerdmans, 69-80.

Folwerda, D.E. 1992. 'Eschatology and Fistory: A Look at Calvin's Eschatological Vision.' Fd. R.C. Gamble. Calvin's Theology, Theology Proper, Eschatology. New York: Garlemd Publishing, 130-59.

Hooker, M.D. 1971. 'Interchange in Christ.' ITS .v.S. 22, 349-61,

.1978. 'Interchange and $\Lambda$ tonement.' BJRL 60, 462-81. 
1981. 'Interchange and suffering.' Eds. W. Horbury \& B. McNeil. Suffering and Martyrdom in the New Testament: Studies Presented to G.M. Styler by the Cambridge New Testament Seminar. Cambridge: CUP, 70-83.

.1993. 'Chalcedon and the New Testament.' Eds. S. Coakley \& D. Pailin. The Making and Remaking of Claristian Doctrine: Essays in Honono of Manrice Wiles. Oxford: Clarendon Press, 73-93.

Horsley, R.A. (ed.). 1997. Paul and Empire: Religion and Power in Roman Imperial Society. Harrisburg: Trinity Press International.

(ed.). 2000. $Y_{a u l}$ and Folitics: Ekklesia, Israel, imperizm, interpretation. Harrisburg: Trinity Press International.

Howard, J.E. 1986. 'The New Historicism in Renaissance Studies.' ELR 16, 13-43.

Hughes, F.W. 1990. 'The Rhetoric of 1 Thessalonians.' Ed. R.T. Collins. The

Thessatonian Correspondence. Leuven: Leuven. University Press, 94-116.

Hultgren, A.J. 1987. Christ and His Benefits: Christology and Redemption in the New Testament. Philadelphia: Fortress Press.

Hunsinger, G. 2000. 'Karl Barth's Christology: Its Basic Chalcedonian Character.' Ed. J. Webster. The Cambridge Companion to Karl Barth. Cambriđge: CUP, 127-42. Hurd, J.C. 1986. 'Paul Ahead of His Time: 1 Thess. 2:13-16.' Eds. P. Richardson \& D. Granskou. Anti-Judaism in Early Christimity. Ontario: Canadian Corporation for Studies in Religion, 21-36.

Iggers, G.G. 1995. 'Historicism: The History and Meaning of the Term.' Joumal of the History of Ideas $56,129-52$.

Jeanrond, W. 1988. 'Karl Barth's Hermeneutics.' Ed. N. Biggar. Reckoning with Barth: Essays in Commenoration of the Centenary of Karl Barth's Birth. London: Muwbray, 80-97.

.1993. 'Theology in the context of pluralism and postmodernity: David. Tracy's theological method.' Ed. D. Jasper. Postmodernism, Literature and the Future of Theology. Basingstoke: Macmillan, 143-63.

Jenson, R.W. 1999. 'The Religious Power of Scripture.' SJ1' 52, 89-105.

Jewett, R. 1986. The Thessalonian Correspondence: Pauline Rhetoric and Millenarian Piety. Minneapolis: Fortress Press. 
Johnson, L.T. 1996. The Real Jesus: The Misguided Quest for the Historical Jesus and the Truth of the Traditional Gospels. New York: Harper Collins.

.1998. 'Imagining the World Scripture Imagines.' MT' $14,165-80$.

Johnson, J.F. 1984. 'Biblical Authority and Scholastic Theology.' Ed. J.D. Hannah. Inerrancy and the Church. Chicago: Moody Press, 67-97.

Johnson, M.F. 1992. 'Another Look at the Plurality of the Literal Sense.' Medieval Philosophy and Theology 2, 117-41.

Jordan, M.D. 1987. 'Theological Exegesis and Aquinas's Treatise "against the Greeks".' CH 56, 445-56.

Jowett, B. 1861. 'On the Interpretation of Scripture' in Essays and Reviezus. I.ondon: Longman, Green, Longman and Roberts, 330-433.

Jülicher, A, 1968. 'A Modern Interpreter of Paul.' [Transl. K.R. Crim]. Ed. J.M.

Robinson. The Beginnings of Dialectic Theology. Volume I. Richmond: John Knox Press, 72-81.

Jïngel, E. 1986. 'Theology as Metactiticism: Toward a I-lermenettic of Theological Exegesis' in Km Barth: A Theological Legacy. [Transl. G.E. Paul]. Philadelplia: Westminster Press, 70-82.

Jurgensen, H. 1994. 'Awaiting the Return of Christ: A RemExamination of 1 Thessalonians 4:13-5:11 from a Pentecostal Perspective.' JPT 4, 81-113.

Käsemann, E. 1969. 'The Saving Significance of the Death of Jesus in Paul' in Perspectives on Paul. [Transl. M. Kohl]. London: SPCK, 32-59.

1971. 'Some Thoughts on the Theme 'The Doctrine of Reconciliation in the New Testament': ['Iransl. C.E. Carlston \& R.P. Scharlemann]. Ed. J.M. Robinson. The Future of our Religious Past: Essays in Yonour of Rudolf Bultmann. London: SCM, 49-64.

Keating, D.A. 2003. 'Divinization in Cyril: 'The Appropriation of Divine Life.' Eds.

T.G. Weinandy \& D.A. Keating. The Theology of St Cyrit of Alexandria: A Critical Appreciation. London: T\&T Clark, 149-85.

Kelley, D.R. 1970. Foundations of Modern Historical Scholarship: Language, Law, and

History in the French Rentissance. New York: Columbia University Press.

Kennedy, R.G. 1985. Thomas Aquinas and the Literal Sense of Sacred Scripture.

Unpublished PhD Thesis, University of Notre Dame.

Khiok-Khng, Y. 1998. 'A Political Reading of Paul's Eschatology in I and II 
Thessalonians.' AJT 12, 77-88.

Koen, L. 1991. The Saving Passion: Incarnational and Soteriological Thought in Cyril of Alexandria's Commentary on the Gospel According to St. John. Uppsala: Acta Universitatis Upsaliensis.

Koester, H. 1990. 'From Pat1's Eschatology to the Apocalyptic Schemata of 2

Thessalonians.' Ed. R.F. Collins. The Thessalonian Correspondence. Leuven: Leuven University Press, 441-58.

Kramer, W. 1966. Christ, Lord, Son of God. [Transl. B. Llardy]. London: SCM.

Kraus, H.-J. 1992. 'Calvin's Exegetical Principles.' Fd. R.C. Gamble. Calvin and Hermeneutics. New York: Garland Publishing, 2-12.

LaCapra, D. 1983. 'Rethinking Intellectual History and Reading Texts' in Rethinkingr Intellectual History: Texts, Contexts, Language. Ithaca: Cornell University Press, $23-71$.

Lamb, M. L. 1966. 'Introduction' in Thomas Aquinas, Conmentary on Saint Paul's Epistle to the Ephesians. [Transl. M.L. Lamb]. Albany: Magi Books, 1 36.

Lane, A.N.S. 1981. 'Calvin's use of the Fathers and the Medievals.' CTJ 16, 149-205.

Lash, N. 1979. 'Interpretation and Imagination.' Ed. M. Goulder. Incarnation and Myth: The Debate Continued. London: SCM, 19-26.

.1985. 'What Might Martyrdom Mean?' Ex Auditu 1, 14-24. .1997. 'The Church in the State We're In.' Eds. L.G. Jones \& J.J. Buckley. Spirituality and Socinl Embodiment. Oxford : Blackwcll, 121-37.

Lassen, E. 1991. 'The Use of the Father Image in Imperial Propaganda and 1 Corinthians 4:14-21.' TB 42, 127-36.

Lee, D.E. \& Beck, R.N. 1954. 'The Meaning of "Historicism"! The American Historical Review 59, 568-77.

Leget, C. 1997. Living with God: Thomas Aquinas on the Relation between Life on Earth and 'Life' afler Death. Leuven: Peeters.

Lindbeck, G. 1984. The Nature of Doctrine - Religion and Theology in a Postliberal Age. Philadelphia: Westminster Press. .1986. 'Barth and Textuality.' 'Theology 'Today 43, 361-76. .1987. 'The Story-Shaped Church: Critical Exegesis and Theological Interpretation.' Ed. G. Grecn. Scriptural Authority and Narrative Interpretation. Philadelphia: Fortress Press, 161-178. 
.1988a. 'Scripture, Consensus and Community.' This World 23, 5-24.

.1988b. 'The Search for Habitable 'Texts.' Daedalus 117, 153-6.

.1989. 'The Church's Mission to a Postmodern Culture.' Ed. F.B. Burnham.

Postmodern Theology: Christian Faith in a Pluralist World. San Francisco: Harper and Row, 37-55.

Linder, R.D. 1975. 'Calvinism and Humanism: The First Generation.' CH 41, 167-81.

Lohfink, G. 1977. Death is not the Final Word. [Trans1. R.J. Cunningham]. Chicago: Tranciscan Ferald Press.

Lossky, V. 1974. The Innge and Likeness of Got. [Various translators]. Eds. J.H.

Erickson \& T.E. Bird. London: Mowbrays.

1976. The Mystical Theology of the Fastem Church. [Various translators]. Crestwood: SVSP.

Longenecker, R.N. 1985. 'The Nature of Paul's Early Eschatology.' NTS 31, 85-95.

Loughlin, G. 1995. 'Using Scripture: Community and Lelteralily.' Eds. J. Davies, G.

Tarvey \& W.G.E. Watson. Words Remembered, lexts Renewed: Essays in Honour of John F.A. Siwyer. JSOTSup 195. Sheffield: Sheffield Academic Press, 321-39. 1996. Telling God's Story: Bible, Church and Narrative Theology. Cambridge: CUP.

.1997. 'I'he basis and authority of doctrine.' Ed. C. Gunton. The Cambridge Companion to Christian Doctrine. Cambridge: CUP, 41-64.

Louth, A. 1978. Theology and Spirituality. Revised edition. Oxford: Sisters of the Love of God Press.

1983. Disceming the Mystery: An Essay on the Nature of Theology. Oxford: Clarendon Press.

1996. Maximus The Confessor. London: Routledge.

.1997. 'The Orthodox Dogmatic Theology of Dumitru Stăniloae' MT 13, 25367.

2002. St John Damascene: Tradition and Originality in Byzantine Theology. Oxford: OUP.

Ludlow, M. 2000. Universal Salvation: Eschatology in the Thought of Cregory of Nyssa and Karl Rahner. Oxford: OUP.

Luz, U. 1990. Matthew 1-7: A Commentary. [Transl, W.C. Linss]. Edinburgh: T\&T Clark. 
1994. Matthew in History: Interpretation, Influence, and Effects. Minneapolis: Fortress Press.

.1995. 'The Disciples in the Gospel According to Matthew.' [Transl. $R$. Morgan]. Ed. G. Stanton. The Interpretation of Matthew. Edinburgh: T\&T Clark, $115-48$.

Malherbe, A.J. 1970. "Gentle as a Nurse": The Cynic Background to I Thess ii.' Nov'l" $12,203-217$

.1983. 'Exhorlation in First Thessalonians.' NovT 25, 238-256.

.1989. 'Patl - Fellenistic Philosopher or Christian Pastor?' in Paul and the Popular Philosophers. Minneapolis: Fortress Press, 67-79.

.1990. 'Pastoral Care' in the Thessalonian Church.' NTS 36, 375-91.

.1995. 'God's New Family in Thessalonica.' Eds. L.M. White \& D.L. Yarbrough. The Social World of the First Christians: Essays in Honor of Wayne A. Meeks, Minneapolis: Fortress Press, 116-125.

.1998. 'Conversion to Paul's Gospel.' Eds. A.J. Malherbe, F.W. Norris \& J.W. Thompson. The Early Church in Its Conlext: Essays in Honor of Everett Ferguson. Leiden: E.J. Brill, 230-244.

.2000. The Letter to the Thessalonians: A New Translation with Introduction and Commentary. AB. New York: Doubleday.

Mann, N. 1996. 'The origins of humanism.' Ed. J. Kraye. The Cambridge Companion to Renaissance Humanism. Cambridge: CUP, 1-19.

Mantzaridis, G.1. 1984. The Leification of Man: St Gregory Palamas and the Orthodox Tradition. [Transl. L. Sherrard]. Crestwood: SVSP.

.1987. 'Spiritual Life in Palamism.' Ed. J. Raitt. Christian Spirituality: IItgh Middle Ages and Reformation. New York: Crossroad, 208-22.

Marshall, B.D. 1987. Christology in Confict: The Identity of a Saviou in Rahner and Barth. Oxford: Basil Blackwell.

Marshall, I.I. 1982. 'Pauline Theology and the Thessalonian Correspondence.' Eds.

M.D. Hooker \& S.G. Wilson. Paul and Paulinism: Essays in Honour of C.K. Barrett. London: SPCK, 173-83.

Martin, R.P. 1981. Reconciliation: A Study of Paul's Theology. London: Marshall, Morgan and Scott.

Mascall, E.L. 1977. Theology and the Gospel of Christ. London: SPCK. 
Maturex, A. 1979. St Thomas and Historicity. Milwaukee: Marquette University Press.

McCormack, B.I. 1991. 'Historical Criticism and Dogmatic Interest in Karl Barth's Theological Exegesis of the New Testament.' Eds. M.S. Burrows \& P. Rorem. Biblical Hermeneutics in Historical Perspective: Studies in Honor of Kanlfried Froehtich on his Sixticth Birthday. Grand Rapids: Eerdmans, 322-38.

.1995. Kanl Barth's Critically Realistic Dialectical Theology: Its Genesis and Development 1909-36. Oxford: Clarendon Press.

.2002. 'The Significance of Karl Barth's Theological Exegesis of Philippians' in Karl Barth, Epistle to the Philippians. [Transl. J.W. Leitch]. Louisville: Westminster John Knox Press, v-xxv.

McDermot, B.O. 1980. 'The Bonds of Freedom.' Ed. L.J. O'Donovan. A World of Grace: An Introduction to the Themes and Foundations of Kanl Rahner's Theology. New York: Seabury Press, 50-63.

McGrath, A. 1987. The Intellactual Origins of the European Reformation. Oxford: Blackwelt.

McGuckin, J.A. 1986. The Transfiguration of Christ in Scripture and Tradition. Lewiston: Edwin Mellen Press.

.1989. 'The Patristic Exegesis of the Transfiguration.' Ed. E.A. Livingstone. SP 17. Leuven: Peeters Press, 335 41 .

1994. St Cyril of Alexandria: The Christological Controversy, Its History, Theology, and Texts. Leiden: E.J. Brill.

2001. Standing in God's Holy Fire: The Byznntine Tradition. London: DLL'.

McGuckin, 'T. 1993. 'Saint Thomas Aquirnas and Theological Exegesis of Sacred. Scripture' New Blackfriars 73, 197-213.

McIntosh, M.A. 1998. Mysticn Theology: The Integrity of Spirituality and Theology. Oxford: Blackwell.

McIntyre, J. 1992. The Shape of Soteriology: Studies in the Doctrine of the Death of Christ. Edinburgh: T\&T Clark.

McKee, E.A. 1989. 'Exegesis, 'Theology, and Development in Calvin's Institutio: A Methodological Suggestion.' Eds. E.A. McKee \& B.G. Armslrong. Probing the Refomed Tradition. Louisville: Westminster Joln Knox Press, 154-72.

.1991. 'Some Reflections on Relating Calvin's Exegesis and Theology.' Eds. M.S. Burrows \& P. Rorem. Biblical Hermeneulics in Historical Perspective: Studies 
in Honor of Karlfried Froehlich on his Sixtieth Birthday. Grand Rapids: Eerdmans, $213-26$.

McKinion, S.A. 2000. Words, Imagery, and the Mystery of Christ: A Reconstruction of Cyril of Alexandria's Christology. Leiden: E.J. Brill.

McNally, R.t. 1961. 'Medieval Exegesis.' TS 22, 445-54.

Mearns, C.L. 1980-1. 'Early Eschatological Development in Pat1: The Evidence of I and It Thessalonians.' NTS 27, 137-157.

Merk, O. 2000. '1 Thessałonians 2:1-12; An Excgeticat Study.' Eds. K.P. Donfried \& J. Beutler. The Thessalonimns Debate: Methotological Discord or Methodological Synthesis? Grand Rapids: Eerdmans, 89-113.

Meyendorff, J, 1964. A Study of Gregory Palamas. ['I'ransl. G. Lawrence]. London: The Faith Press.

.1975. Christ in Eastern Christian Thought. [Transl. Y. Dubois]. Crestwood: SVSP.

1980. 'Foreword' in Dumitru Staniloae, Theology and the Church. [Transl. R. Barringer]. Crestwood: SVSP, 7-9.

1983. Byzantine Theology: Historical Trends and Doctrinal Themes. 2nd edition. New York: Fordham University Press.

.1987. 'Christ's Humanity: The Paschal Mystery.' SVTQ 31, 5-40.

Meyer, H. 1946. The Philosophy of St. Thomas Aquinas. [Transl. T. Eckhoff]. St. Louis: Herder.

Miguez Bonino, J. 1975. 'Hermeneutics, Truth, and Praxis' in Doing Theology in a Revolutionary Situation. Philadelphia: Fortress Press, 86-105.

Milbank, J. 2000. 'The Conflict of the Faculties: Theology and the Economy of the Sciences.' Eds. M.T. Nation \& S. Wells. Faitlfulness and Fortitude: In Conversation with the Theological Ethics of Stanley Haterwas. Edinburgh: T\&T Clark, 39-57.

Miller, C. 2000. The Gift of the World: An Introduction to the Theology of Dumitru Stăniloae. Edinburgh: T\&T Clark.

Milligan, G. 1908. St Paul's Epistles to the Thessaloninns: the Greek text with an Introduction and Notes. London: Macmillan.

Mitchell, B. \& Wiles, M. 1980. 'Docs Christianity need a Revelation? A Discussion.' Theology 83, 103-114.

Mitchell, M.M. 2002. The Henoenly Trumpet: John Chrysostom and the Art of Pauline 
Interpretation. Louisville: Westminster John Knox Press.

Moberly, R.W.L. 2000. The Bible, Theology and Faith: A Study of Abruham and Jesus. Cambridge: CUP.

Moltmann, J. 1985. 'Christian Iope: Messianic or Transcendent? A Theological

Discussion with Joachim of Fiore and Thomas Aquinas.' [Transl. M.D. Meeks]. Horizons 12, 328-48.

Moo, D.J. 1996. The Epistle to the Romans. NICNT. Grand Rapids: Ecrdmans.

Morgan, R. 1.973a. 'Expansion and Criticism in the Christian Tradition.' Eds. R.

Morgan \& M. Pye. The Cardinal Meaning: Essays in Comparative Hermeneutics, Buddhism and Christianity. The Haguc: Mouton Press, 59m101.

.1973b. The Nature of New Testament Theology. London: SCM.

1987. 'The Historical Jesus and the Theology of the New Testament:' Eds.

L.D. IIurst \& N.T. Wright. The Glory of Christ in the Nerv Testament: Studies in Christology in Mentory of George Bradfort Caird. Oxford: Clarendon Press, 187206.

.1990. 'Historicism.' Eds. R.J. Coggins \& J.L. Houlden. A Dictionary of Biblical Interpretation. London: SCM, 290-1.

.1995. Romans. Sheffield: Sheffield Academic Press.

Morris, L. 1991. The First and Second Epistles to the Thessalonians. NICNT. Revised edition. Grand Rapids: Eerdmans.

Moule, C.E.D. 1977. The Origins of Christology. Cambridge: CUP.

Myung, J.A. 1999. 'The influences on Calvin's hermeneutics and the development of his method.' Hervornde Teologiese Studies 55, 228-39.

Muller, R.A. \& Thompson, J.L. 1996. 'The Significance of Pre-critical Exegesis:

Retrospect and Prospect.' Ects. R.A. Muller \& J.L. Thompson. Biblical Interpretation in the Era of the Reformation: Essays Presented to David C. Steinmetz in Honor of his Sixtieth Birthday. Grand Rapids: Eerdmans, 335-345.

Nicole, R. 1982. 'Tohn Calvin and Inerrancy.' JETS 25, 425-42.

Oberman, H.O. 1994. 'Initia Calvini: The Matrix of Calvin's Reformation.' Ed. W.H.

Neuser. Calvinis Sacrae Scripturae Professor. Grand Rapids: Eerdmans, 113-54.

Ollenburger, B.C. 1985. 'Biblical Theology: Situating the Discipline.' Eds. J.T Butler et 
al. Understanding the Word: Essays in Honor of Bernard W. Anderson. JSOTSup 37. Sheffield: Sheffield Academic Press, 37-62.

1986. 'What Krister Stendahl "Meant" - A Normative Critique of "Descriptive Biblical Theology".' HBT 8, 61-98.

O'Meara, T.17. 1997. Thomas Aquinas - Theologian. Notre Dame: University of Notre Dame Press.

O'Loughlin, T. 1998. 'Christ and the Scriptures: the Chasm between Modern and Premodern Exegesis.' The Month 31, 475-85.

Ouspensky, L. 1982. 'The Meaning and Language of Icons' in L. Ouspensky \& V. Lossky, The Meaning of Icons. [Transl. G.E.H. Palmer \& E. Kadloubovsky]. Crestwood: SVSP, 23-49.

Packer, J.I. 1984. 'John Calvin and the Inerrancy of Foly Scripltue.' Ed. J.D. Hannah. Inermancy and the Church. Chicago: Moody Press, 143-88.

Pailin, D. 1970. 'Incarnation as a continuing reality.' RS 6, 303-27.

Parker, T.H.I. 1971. Calvin's New Testiment Commentaries. Tondon: SCM.

.1992. 'Calvin the Biblical Expositor.' Ed. R.C. Gamble. Caloin and Hermeneutics. New York: Garland Press, 65-73.

Partee, C. 1969. 'The Soul in Plato, Platonism, and Calvin.' SJT 22, 278-95.

.1977. 'Soul and Body in Anthropology' in Calvin and Classical Philosophy. Leiden: E.J. Brill, 51-65.

Payton, J.R. 1992. 'History as Rhetorical Weapon: Christian Humanism in Calvin's Reply to Sadoleto, 1539.' Ed. R.C. Gamble. Calvin's Early Writings and Ministry. New York: Garland Press, 208-44.

Pearson, B.A. 1971. '1 Thessalonians 2:13-16: A Deutero-Pauline Interpretation.' HTR $64,79-94$.

Persson, P.E. 1970. Sacru Docrina: Reason and Revelation in Aquinas. [Transl. R. Mackenzie]. Oxford: Basil Blackwell.

Pesch, O.M. 1974. 'Paul as Professor of Theology: The Image of the Aposte in St. Thomas' Theology.' The Thomist 38, 584-605.

Phan, P.C. 1988. Eternity in Time: A Study of Karl Rahner's Eschatology. Selinsgrove: Susquehanna University Press.

Pitkin, B. 1999. What Pure Eyes Could See: Calvin's Doctrine of Fath in its Exegetical Context. Oxford: OUP. 
Pope, H. 1924. St. Thomas Aquinas as an Interpreter of Holy Scripture, Oxford: Basil Blackwell.

Potts, M. 1998. 'Aquinas, Hell and the Resurrection of the Damned.' Faith and Philosophy 15, 341-51.

Principe, W.I.. 1978. 'Thomas Aquinas' Principles for Interpretation of Patristic Texts.' Studies in Medieval Culture 8, 111-21.

Provence, T.E. 1986. 'The Sovereign Subject Matter: Hermeneutics in the Church Dogmatics.' Ed. D.K. McKim. A Guide to Contemporary Hemeneutics: Major Trends in Biblical Interpretation. Grand Rapids: Eerdmans, 241-62.

Prust, R.C. 1967. 'Was Calvin a Biblical Literalist?' SJT 20, 312-28.

Puckett, D.L. 1995. John Calvin's Exegesis of the Old Testament. Louisville: Westminster John Knox Press.

Quistorp, H. 1955. Calvin's Doctrine of the Last Things. [Transl. H. Knight]. London: Lutterworth Press.

Räisänen, H. 1990. Beyond New Testament Theology: A Story and Programme. London: SCM.

.1992. 'The Effective 'History' of the Bible: A Challenge to Biblical Scholarship.' SJT 45, 303-24.

.1995. 'The New Testament in 'l'heology.' Eds. P. Byme \& L. Houlden. Compunion Encyciopedia of Theology. London: Routledge, 122-41.

.1998. 'Comparative Religion, Theology and New Testament Exegesis.' Studia Theologica $52,116-29$.

. 2000. 'Biblical Critics in the Global Village.' Ld. I-I. Räisänen et nl. Rending the Bible in the Globnl Village. Atlanta: SBL, 9-28.

Rice, E.F. 1961. 'The Humanist Idea of Christian Anticuity: Lefèvre d'Étaples and his Circle.' Strudies in the Renaissance 9, 126-41.

Richard, E.J. 1991. 'Early Pauline Thought: An Analysis of 1 Thessalonians.' Ed. J.M.

Bassler. Pauline Theology. Volume I: Thessalonians, Philippians, Galatians, Philemon. Minneapolis: Fortress Press, 39-51.

.1995. First and Second Thessalonians. SP. Collegeville: The Liturgical Press. Riches, J.K.1994. 'A Future for Now Testament Theology?' Literature and Theology 8 , 
343-53.

.2001. "Theological Interpretation of the New Testament and the History of Religions - Some Reflections in the Light of Galatians 5:17.' Eds. A.Y. Collins \& M.M. Mitchell. Antiquity and Huntanity: Essays on Ancient Religion and Philosophy - Presented to Hans Dieter Betz on His $70^{\text {th }}$ Birthday. Tüloingen: Mohr Siebeck, 245-62.

Ricoeur, P. 1976. Interpretation Theory: Discourse and the Surplus of Meaning. Fort

Worth: Texas Christian University Press.

1981. 'Toward a Ilermeneutic of the Idea of Revelation' in Fssays in Biblical Interpretation. Ed. L.S. Mudge. London: SPCK, 73-118.

1989. 'Response to Josef Blank.' Eds. H. Kung \& D. Tracy. Paradigm Change int Theology: A Stmpositm for the Future. Edinburgh: T\&T Clark, 283-6.

Robinson, J.A.T. 1957. The Body: A Study in Pauline Theology. London: SCM.

Rodgers, R. 1982. 'An Introduction to the Anabaptists.' EQ 54, 36-45.

Rogers, Jr., E.F. 1995. Thomas Aquinas and Karl Barth: Sacred Doctrine and the Natural

Knowledge of God. Notre Dame: University of Notre Dame Press.

.1996. 'How the Virtues of at Interpreter Presuppose and Perfect I-Iermeneutics: The Case of Thomas Aquinas.' JR 76, 64-81.

Rogich, D. 1988. 'Homily 34 of Saint Gregory Palamas.' GOTR 33, 135-66.

Rossouw, H.W. 1982. 'Calvin's Hermeneutics of Holy Scripture.' No Editor. Caloinus Reformatur: His Contribution to Theology, Chttrch and Society. Potchefstrom: Potchefstroom University for Christian. Higher Education, 149-80.

Rousseat, M.F. 1979. 'Elements of a Thomistic Philosophy of Death.' The Thomist 43, $581-602$.

Russell, N. 1988. 'Partakers of the Divine Nature' (2 Peter 1:4) in the Byzantine. Tradition.' Ed. J. Chrysostomides. Kahregetriä: Essays Presented to Joan Hussey for her 80th Birthday. Camberley: Porphyrogenitus, 51-67. .2000. Cyril of Alexandria. London: Routledge.

Russo, G. 1988. 'Rahner and Palamas: A Unity of Grace,' SVTQ 32, 157-80.

Sabra, G. 1987. Thomas Aquinas' Vision of the Chirch: Fundanentals of an Ecumenical Ecclesiology. Mainz: Matthias-Grünewald-Verlag.

Sanders, E.P. 1977. Paul and Palestinian Judnism: A. Comparison of Patterns of Religion. London: SCM. 
Sandys-Wunsch, J. and Eldredge, L. 1980. 'J.P. Gabler and the distinction between

Biblical Studies and Dogmatic Theology: Translation, Commentary and discussion of his originality.' S/l' $33,133-58$.

Sanks, T.II. 1993. 'David Tracy's Theological Project : An Overview and Some Implications.' TS 54, 698-727.

Schaff, P. 1892. 'Calvin as a Commentator.' Presbyterian and Reformed Rertew 3, 462-9. Schmemann, A. 1990. 'Liturgy and Eschatology' in Liturgy and Thatition: Theological Reflections of Alexander Schmemann. Ed. T. Fisch. Crestwood: SVSP, 89-100. Schmithals, W. 1972. Panl and the Gnostics. [Transl. J.E. Steely]. Nashville: Abingdon Press.

Scholl, H. 1997. 'Karl Barth as Interpreter of Calvin's Psychopatinychia.' [Transl. E.]. Furcha]. Eds. W.H. Neuser \& B.G. Armstrong. Calvinus Sincerioris Religionis Vindex. Kirksville: Sixteenth Century Publishing Inc, 291-308.

Schweitzer, A. 1931. The Mysticism of Paul the Apostle. [I'ransl. W. Montgomery]. London: A\&C Black.

Schweizer, E. 1967. 'Dying and Rising with Christ.' NTS 14, 1-14.

Seifrid, M.A. 1993. 'In Christ.' Eds. G.F. Hawthorne, R.P. Martin \& D.G. Reid.

Dictionary of Paul and his Letters. Downets Grove: Inter Varsity Press, 433-6.

Shanley, B.J. 1997. 'Etemal Knowledge of the Temporal in Aquinas.' Anerican Catholic Philosophicul Quarteriy 17, 197-224.

Sheets, J. 1961. 'The Scriptural Dimension of St. Thomas.' American Ecclesiastical Review 144, 154-73.

Shepphard, G.T. 1989. 'Between Reformation and Modern Commentary: The Perception of the Scope of Biblical Books.' Ed. G.T. Shepphard. A Contmentary - Galatians, William Perkins. New York: Pilgrim Press, xlviii-lxxvii.

Sherrard, P. 1998. 'On Death and Dying: A Christian Approach' in Christianity: Lineaments of a Sacred Tradition. Edinburgh: T\&T Clark, 180-99.

Sherwood, Y. 2000. A Biblical Text and its Afterlives: The Survival of Jonah in Western Culture. Cambridge: CUP.

Smalley, B.S. 1952. The Study of the Bible in the Middle Ages. Oxford: Blackwell.

1985. The Gospels in the Schools. London: Hambledon Press.

Smeeton, D.D. 1982. 'Calvin's Conflict with the Anabaptists.' EQ 54, 46-54.

Smith, A. 1995. Comfort One Another-Reconstructing the Rhetoric and Audience of 1 Thessalonians. Lotisville: Westminster John Knox Press. 
Smith, J.W. 2002. 'Suffering Impassibly: Christ's Passion in Cyril of Alexandria's Soteriology.' Pro Ecclesia 11, 463-83.

Stăniloae, D. 1980. Theology and the Church. [Transl. R. Barringer]. Crestwood: SVSP. .1982. Prayer and Holiness. [Translated by the Sisters of the Love of God]. Oxford: Sisters of the Love of God Press.

.1986. 'The Mystery of the Church.' [No translator]. Ed. G. Limouris. Church, Kingdom, World: The Church as Mystery and Prophetic Sign. Geneva: World Council of Churches, 50-57.

.1994. The Experience of God. Orthodox Dogmatic Theology. Volume I: Revelation and Knowledge of the Triune God. [Transl. \& eds. I. Ionila \& R. Barringer]. Brookline: Holy Cross Orthodox Press.

.2001. Eternity and Time. [Transl. D. Allchin]. Oxford: Sisters of the Love of God Press.

Stanley, D.M. 1961. Christ's Resurrection in Pauline Sateriology. Rome: E Pontificio Instituto Biblico.

Stanton, G. 1977. 'Presuppositions of New 'Testament Criticism.' Ed. I.H. Marshall.

New Testament Interpretation: Essays on Principles and Methods. Carlisle: Patemoster Press, 60-71.

Steinmetz, D.C. 1980. 'The Stiperiority of Pre-Critical Exegesis.' Theology Today 37, 2738.

.1984. 'Luther and Calvin on Church and Tradition.' Michigan Gemanic Studies 10, 98-111.

Stendahl, K. 1962. 'Biblical Theology, Contemporary.' Ed. G.A. Buttrick et al. The Interpreter's Dictionary of the Bible. New York: Abingdon Press, 418-32.

.1965. 'Method in the Study of Biblical Theology.' Ed. J.P. Hyatt. The Bible in Modern Scholarship. London: Carcy Kingsgate Press, 196-209.

.1976. Paul Among Jews and Gentiles and Other Essays. Minneapolis: Fortress Press.

.1984. 'The Bible as Classic and the Bible as Holy Scripture.' JBL 103, 3-10.

.2000a. 'Dethroning Biblical Imperialism in Theology.' Ed. H. Räisänen et al. Reading the Bible in the Global Village. Atlanta: SBL, 61 66.

.2000b. 'Biblical Theology, Contemporary.' Ed. H. Räisänen et al. Reading the Bible in the Global Village. Ntlanta: SBL, 67-106.

Still, T. 1999. Conflict at Thessalonica: A Paulne Church and its Neighbours. JSNTSup 
183. Sheffield: Sheffield Academic Press.

Stout, J. 1982. 'What is the Meaning of a Text?' NLH 14, 1-12.

.1986. 'The Relativity of Interpretation.' The Monist 69, 103-18.

Stuhlmacher, P. 1986. 'On. Pauline Cluristology' in Reconciliation, Law and

Righteousness: Essays in Biblical Theology. [Transl. E. Kalin]. Philadelphia: Fortress Press, 169m81.

Stump, E. 1993. 'Biblical commentary and philosophy.' Eds. N. Kretzmann \& E.

Stump. The Cambridge Companion to Aquinas. Cambridge: CUP, 252-68.

.1994. 'Revelation and Biblical Exegesis: Augustine, Aquinas and Swinburne.'

Ed. A. Padgett. Reason and the Christian Religion: Essays in Honour of Richard Swinburne. Oxford: Clarendon Press, 161-97.

Swinburne, R. 1992. Revelation: From Metaphor to Analogy. Oxford: Clarendon Press.

Tarazi, P.N. 1982. 1 Thessalonians: A Commentary. Crestwood: SVSP.

Tannehill, R.C. 1967. Dying and Rising with Christ: A Stuty in Patine Theology. Berlin: Verlag Alfred Töpelmann.

Tanner, K. 2001. Jesus, Fumanity and the Trinity: A Brief Systematic. Theology. Edinburgh: T\&T Clark.

Tavard, G.H. 2000. The Starting Point of Calvin's Theology. Grand Rapids: Eerdmans. Thiselton, A.C. 1992. New Horizons in Hermeneutics. Iondon: Harper Collins.

2000. The First Epistle to the Corinthians: A Commentary on the Greek Text. NIGTC. Grand Rapids: Eerdmans.

Thompson, B. 1996. 'Calvin' in Humanists and Reformers: A History of the Renaissance and Reformation. Grand Rapids: Eerdmans, 471-502.

Thumberg, L. 1985. Man and the Cosmos: The Vision of St. Maximus the Confessor. Crestwood: SVSP.

Torrance, T.F. 1956. Kingdom and Chuch: A Study in the Theology of the Reformation. Edinburgh: Oliver and Boyd.

.1957. 'The Eschatology of the Reformation.' Eds. T.F. Torrance \& J.K.S. Reid, Eschatology. SJT Occasional Papers No.2. Edinburgh: Oliver and Boyd, 36-62. .1962. 'Scientific Hermeneutics According to St. Thomas Aquinas.' ITS N.S. 13, $259-89$.

.1975. 'The Mind of Christ in Worship: The Problem of Apollinarianism in the Liturgy' in Theology in Reconoiliation. London: Geoffrey Chapman, 139-214. 
.1988a. The Hermeneutics of John Calvin. Edinburgh: T\&T Clark.

.1988b. 'The Incarnate Saviour' in The Trinitarian Faith: The Evangelical Theology of the Ancient Catholic Church. Edinburgh: T\&T Clark, 146-90.

1990. Kanl Barth: Biblical and Evangelicul Theologian. Edinburgh: T\&T Clark. 1995. Divine Menning: Studies in Patriatic Hemeneutics. Edinburgh: T\&'T Clark. Torrell, J.-P. 1996. Sainl Thomas Aguinas, Volume I: The Person and his Work. [Transt. R. Royal]. Washington: CUAP.

Tracy, D. 1981. The Analogical Imagination: Christian Theology and the Culture of Plutulism. London: SCM.

.1984a. 'Creativity in the Interpretation of Religion: The Question of Radical Pluralism.' NIH 15, 289-309.

$.1984 \mathrm{~b}$. 'Is a hermeneutics of religion possible?' Ed. L.S. Rouner. Religionı Pinralism. Notrc Dame: University of Notre Dame Press, 116-29.

1987. Plutality and Ambiguty. London: SCM.

.1989. 'The uneasy alliance reconceived: Catholic theological method, modcrnity, and postmodernity.' TS 50, 548-70.

Trites, A.A. 1987. "The Transfiguration in the Theology of Luke: Some Redactional Links.' Eds. L.D. Hurst \& N.T. Wright. The Glory of Clirist in the New T'estument: Studies in Christology in Memory of George Brudford Caird.

Oxford: Clarendon Press, 71-81.

Tugwell, S. 1988a. Albert and Thomas: Selected Writings. [Ed. \& transl. S. Tugwell].

New York: Paulist Press.

.1988b. 'Introduction' in Albert and Thomas: Selected Writings. [Ed. \& transl. S. Tugwell]. New York: Paulist Press, 201-351.

Tutner, H.E.W. 1952. The Patristic Doctrine of Redemption. London: Mowbray. Tyrrell, G. 1913. Christinnity at the Cross-Roads. London: Longmans.

Valkenberg, W.G.B.M. 1991. 'Readeis of Scripture and Hearers of the Word in the Medieval Church.' Concilium 1, 47-57. 2000. Words of the Living God: Place and Function of Holy Scripture in the Theology of St. Thonus Aquinas. Leuven: Peelers.

Van Oort, J. 1997. 'John Calvin and the Church Fathers.' Ed. I. Backus. The Reception of the Church Fathers in the West. Volume 2. Leiden: E.J. Brill, 661-700.

Vass, G.T. 1962. "Secundum Illud Apostoli": A Study of the Use of Biblical Auctoritas in 
the Systematic Theology of Thomas Aquinas. Rome: Pontificia Universitas Gregoriana.

Vickers, M.J. 1972. 'Hcllenistic Thessaloniki.' The Journal of Hellenic Studies XCII, 15670.

Vos, J.S. 2000. 'On the Background of 1 Thessalonians 2:1-12: A Response to Traugott Holtz.' Eds. K.P. Donfried \& J. Beutler. The Thesalonians Debate: Methodological Discord or Methotological Synthesis? Grand Rapids: Eerdmans, 81-88.

Walchenbach, J.R. 1974. John Calvin as Biblical Commentator: An Investigation into Calvin's use of John Cmysostom as an Exegetical Tutor. Unpublished PhD Thesis, Universily of Pittsburgh.

Walton, S. 1995. 'What Has Aristotle To Do with l'aul? Rhetorical Criticism and 1 Thessalonians.' TB 46, 229-50.

Wanamaker, C.A. 1990. The Epistles to the Thessaloninns. NIGTC. Grand Rapids: Eerdmans.

Ware, K. 1975. 'God Hidden and Revealed: The Apophatic Way and the EssenceEnergies Distinction.' Eastern Churches Review 7, 125-36.

.2000. 'The Inner Kingdom. Crestwood: SVSP.

Watson, D.P. 1999. 'Paul's Appropriation of Apocalyptic Discourse - The Rhetorical Stralegy of 1 'Thessalonians.' Eds. G Carey \& L..G. Bloomquist. Vision and Persuasion: Rhetorical Dimensions of Apocalyptic Discourses. St Louis: Chalice Press, 61-79.

Watson, F. 1994a. Text, Church and World: Biblical Interpretation in Theological Perspective. Edinburgh: T\&T Clark.

.19941. 'Is Revelation an 'Event'?' MT 10, 383-99.

.1996. 'Bible, Theology and the University: A Response to Philip Davies.' JSOT 71, 3-16.

.1997. Text and Truth: Redefining Biblical Theology. Edinburgh: T\&T Clark.

.2000. 'The Bible.' Ed. J.B. Webster. The Cambridge Companion to Karl Barth. Cambridge: CUP, 57-7\%.

.2002. 'Barth's Philippians as Theological Ixegesis' in Karl Barth, Episte to the Phittppians. [Transl. J.W. I.eitch]. Louisville: Westminster John Knox Press, xxvi-li.

Weaver, D. 1983. 'From Paul to Augustine: Romans 5:12 in Early Christian Exegesis.' 
SVTQ 27, 187-206.

.1985. 'The Exegesis of Romans 5:12 among the Greek Fathers and its Implication for the Doctrine of Origital Sin: The $5^{\text {th }}-12^{\text {th }}$ Cenluries.' SVTQ 29, 133-59 and continued in SVTQ 29, 231-57.

Webster, J. 1992. 'Locality and Catholicity: Reflections on Theology and the Church.' S) $45,1-17$.

.1998. 'Hermeneutics in Modern Theology: Some Doctrinal Redections.' SJT $51,307-41$.

.2000. 'Eschatology, Anthropology and Postmodernity.' International Jownal of Systematic Theology 2, 13-28.

Wedderburn, A.J.M. 1985. 'Some Observations on Paul's Use of the Phrases In Christ' and 'With Christ'.' YSNT 25, 83-97.

Weima, J.A.D. 1997. 'An Apology for the Apologetic Function of 1 Thessalonians 2:112.' JSNT' 68, '73-99.

.2000. 'The Function of 1 Thessalonians 2:1-12 and the Use of Rhetorical Criticism.' Eds. K.P. Donfried \& J. Beutler. The Thessalonians Debate: Methodological Discord or Methodological Synthesis? Grand Rapids: Eerdmans, 114-31.

Weinandy, T.G. 1993. In the Likeness of Sinful Flesh: An Essay on the Humanity of Christ. Edinburgh: T\&T Clark.

Weisheipl, J.A. 1974a. Friar Thomas d'Aquino: His Life, Thought and Work. New York: Doubleday and Company.

.1974b. 'The Meaning of Sacra Doctrina in Summa Theologiae I q.1.' The Thomist $38,49-80$.

.1975. 'The Johannine Commentary of Friar Thomas.' $\mathrm{CH} 45,185-95$.

Wendel, F. 1963. Calvin: The Origins and Development of his Religious Thought. [Trans]. P. Mairet]. London: Collins.

Wengst, K. 1987. P'ax Romana and the Peace of Jesus Christ. [Fransl. J. Bowden]. London: SCM.

Wharton, J.A. 1972. 'Karl Barth as Exegete and His Tnfluence on Biblical Interpretation.' LISQR 28, 5-13.

Wickham, L.R. 1982. 'Symbols of the Incamation in Cyril of Alexandria.' Eds. M. Schmidt \& C.F. Geyer. Typus, Symbol, Allegorie bei den Östlichen Vätem und ihren Parallelen int Mittelalter. Regensburg: Verlag Friedrich Puslet, 41-53. 
Wiles, M.F. 1967. The Divine Apostle: The interpretation of St Paul's Apostles in the Early Church. Cambridge: CUP.

Wilken, R.L. 1966. 'Fxegesis and the History of Theology: Reflections on the AdamClurist Typology in Cyril of Alexandria.' CH 35, 139-56.

.1995. 'St Cyril of Alexandria: The Mystery of Christ in the Bible.' Pro Ecclesia $4,454-78$.

.1998. 'St Cyril of Nlexandria: Biblical Expositor.' Coptic Church Review 19, 3041.

Williams, A.^. 1999. The Ground of Union: Deification in Aquinas ma Palamas. New York: OUP.

Williams, G.H. 1962. 'Calvin and the Radical Reformation' in The Radical Reformation. London: Weidenfeld and Nicholson, 580-614.

Williams, R. 1977a. 'Poetic and Religious Imagination.' Theology 80, 178-87. $.1977 \mathrm{~b}$. 'The Philosophical Structures of Palamism.' Eastern Churches Review 9, $27-44$.

.1982. Resurrection. London: DLT.

1994. Open to Judgement. London: DLT.

1996. 'The Body's Grace.' Ed. C. Hefling. Our Selves, Our Souls and Bodies: Sexuality and the Household of God. Cambridge: Cowley Publications, 58-68. .2000a. On Christian Theology. Oxford: Blackwell.

.2000b. Lost lcons: Reflections on Cultural Bereavement. Edinburgh: T\&T Clark.

Wink, W. 1973. The Bible in Human Transformation. Philadelphia: Fortress Press.

Winslow, D.F. 1979. The Dynamics of Salvation: A Study in Gregory of Nazianzus. Cambridge: Philadelphia Patristic Foundation.

Wright, N.T. 1991. The Climax of the Covenant: Christ and the Law in Pauline Theology. Edinburgh: T\&T Clark.

.1994, 'Gospel and Theology in Galatians.' Eds. L.A. Jervis \& P. Richardson. Gospel in Panl: Studies on Corinthians, Galatians and Romans for Richard $N$. Longenecker. JSN'TSup 108. Sheffield: Academic Press, 222-239.

2000. 'Paul's Gospel and Caesar's Empire,' Ed. R.A. Horsley. Pand and Politics: Ekklesia, Isrnel, Imperium, Interpretation. I Iarrisburg: Trinity Press International. Wyneken, K.H. 1992. 'Calvin and Anabaptism.' Ed. R.C. Gamble. Calvin's Opponents. New York: Garland Publishing, 2-13. 
Yarbro Collins, A. 1984. 'Ftundamentalist Interpretation of Biblical Symbols.' Ed. M.J. Selvidge. Fundamentalism Today: What Makes It So Attractive? Elgin: Brethren Press, 107-114.

Yeago, D.S. 1996. 'Jesus of Nazareth and Cosmic Redemption: The Relevance of St Maximus the Confessor.' MT 12, 163-93.

.1997. 'The New Testament and the Nicene Dogma: A Contribution to the Recovery of 'Theological Exegesis.' Ed. S.E. Fowl. The Theological Interpretation of Scripture: Classic and Contemporary Readings, Oxford: Blackwell, 87-100.

Young, F.M. 1971. 'A Reconsideration of Alexandrian Christology.' JECH 22, 103-14. .1975. Sacrifice and the Death of Christ. London: SPCK.

Zachman, R.C. 2002. 'Gathering Meaning from the Context: Calvin's Exegetical Method.' IR 82, 1-26. 